\title{
Verdier i barnevern
}

Halvor Nordby og Astrid Halsa (red.) 
Verdier i barnevern 

Halvor Nordby og Astrid Halsa (red.)

\section{Verdier i barnevern}

CAPPELEN DAMM AKADEMISK 
(C) 2020 Halvor Nordby, Astrid Halsa, Camilla Bennin, Grethe Netland, Liv Randi Roland, Mari Rysst, Anders Sandvig jr., Lene Nygaard Solli og Kerstin Söderström.

Dette verket omfattes av bestemmelsene i Lov om opphavsretten til åndsverk m.v. av 1961. Verket utgis Open Access under betingelsene i Creative Commons-lisensen CC BY-ND 4.o (https://creativecommons.org/licenses/by-nd/4.o/). Denne tillater tredjepart å kopiere, distribuere og spre verket i hvilket som helst medium eller format under betingelse av korrekt kreditering og at en lenke til lisensen er oppgitt. Lisensen tillater ingen bearbeidelser.

ISBN trykt bok: 978-82-02-68684-O

ISBN PDF: 978-82-02-62429-3

ISBN EPUB: $978-82-02-68726-7$

ISBN HTML: 978-82-02-68727-4

ISBN XML: 978-82-02-68728-1

DOI: https://doi.org/10.23865/noasp.103

Dette er en fagfellevurdert antologi.

Omslagsdesign: Cappelen Damm AS

Cappelen Damm Akademisk/NOASP

noasp@cappelendamm.no 


\section{Innhold}

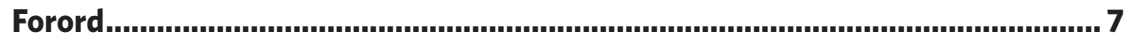

Kapittel 1 Introduksjon................................................................................... 9

Halvor Nordby og Astrid Halsa

Kapittel 2 Barnets beste som juridisk argument i begrunnelser og

beslutninger i barnevernet ............................................................... 25

Camilla Bennin

Kapittel $3 \AA$ A balansere mellom barnevernets prinsipper

Grethe Netland

Kapittel 4 Verdier og kommunikasjon i konfliktsituasjoner.

Halvor Nordby

Kapittel 5 Kulturelle verdier og barnevernet: Ulike forståelser av «barnets beste» .89

Mari Rysst

Kapittel 6 Spenningsforhold mellom beskyttelse og medvirkning

i forskning på familieråd 113

Lene Nygaard Solli

Kapittel 7 Bekymring for det ufødte liv og omsorgsovertakelse ved fødsel: Posisjoner, verdikonflikter og spenninger i tverrfaglig arbeid 131

Kerstin Söderström

Kapittel 8 Familieverdier i spill: Ungdoms erfaringer med barneverntjenesten når mor eller far har rusproblemer eller alvorlig psykiske helseproblemer 153

Astrid Halsa 
Kapittel 9 «SIM spedbarnevern og foreldrestøtte»: Simulering av tverrfaglig samarbeid i verdiladde og sårbare situasjoner

Kerstin Söderström og Anders Sandvig jr.

Kapittel 10 Verdimøter som organisert læringsprosjekt 199

Liv Randi Roland

Forfatterbiografier

219 


\section{Forord}

Denne boken har sitt utspring i fagmiljøet rundt doktorgradsprogrammet «Barn og unges deltakelse og kompetanseutvikling» ved Institutt for sosialfag og veiledning ved Høgskolen i Innlandet. Deltakere i forskingsgruppen Utsatte barn, unge og familier fikk innvilget støtte av Norges forskningsråds program HELSEVEL til forsking på barnevernet. Forskningsprosjektet, Decisions and Justifications in Child Protection Services, studerer og analyserer barnevernets beslutninger og begrunnelser knyttet til det å ivareta hensynet til barnets beste. Prosjektet startet opp i 2018, og denne boken er prosjektets første publikasjon i antologiform. Hensikten med boken har vært å klargjøre og belyse hvordan utøvende barnevernarbeid på forskjellige måter er et svært verdiladet praksisfelt.

Sluttarbeidet med boken har foregått mens Norge har vært nedstengt på grunn av koronapandemien. Skoler og barnehager har vært lukket, og sjelden har vel bekymringen rundt omsorgsituasjonen til sårbare barn og unge hatt større plass i media. Denne boken handler nettopp om ivaretakelse av barn i sårbare livssituasjoner og om barnevernets verdigrunnlag for å gjøre dette. Vi håper at boken vil inspirere fagkollegaer, studenter og en bredere offentlighet til diskusjoner om hva prinsippet om barns beste betyr i ulike kontekster og til ulike tider. Vi som står bak antologien, har hatt en ambisjon om å skape et refleksjonsrom der kapitlene kan bidra til diskusjon omkring dette.

Mange har medvirket i arbeidet som har ledet frem til denne antologien. Først av alt vil vi takke Norges forskningsråd som har støttet og finansiert prosjektet. Takk til alle forfatterne for kapitlene de har skrevet, for tankevekkende bidrag og for berikende samtaler under arbeidsseminarene. Forfatterne har fagbakgrunn fra ulike disipliner, og den interdisiplinære tilnærmingen har skapt en plattform for mange interessante diskusjoner oss kollegaer imellom. Samarbeidet med bidragsyterne har 
lettet redaktøransvaret betraktelig. Takk også til de anonyme fagfellene, som ga konstruktive kommentarer til tidligere versjoner av kapitlene. $\mathrm{Vi}$ vil til slutt rette en spesiell takk til forlagsredaktør Simon Aase og Cappelen Damm Akademisk, som helt fra starten har vist stor interesse for bokprosjektet og kommet med gode innspill underveis.

Lillehammer, mai 2020

Halvor Nordby og Astrid Halsa 


\section{KAPITTEL 1}

\section{Introduksjon}

Halvor Nordby og Astrid Halsa

Høgskolen i Innlandet

Menneskelige aktiviteter er verdiladet. Stort sett gjør vi det vi mener er riktig. Stort sett unngår vi å gjøre det vi mener er galt. ${ }^{1}$ Ofte er vi også, bevisst eller ubevisst, opptatt av å realisere og ivareta mer spesifikke verdier. Vi er, i hvert fall de aller fleste av oss, opptatt av å ivareta grunnleggende verdier som rettferdighet, likhet, solidaritet og frihet.

I profesjonsutøvelse er betydningen av verdiladet praksis satt i system. Profesjonsutøvere har et samfunnsmandat og etisk ansvar for å ivareta og realisere verdier (Christoffersen, 2011). Noen av verdiene er nært knyttet til universelle begreper som frihet og likhet. Andre er mer rettet mot fagområdene profesjonsutøvelsen skjer innenfor. Å ivareta helse er en grunnverdi i helsefag. Velferd er et sentralt begrep i sosialfag. I tillegg har hver profesjon innen disse områdene spesifikke kjerneverdier, slik de forstås faglig, yrkesetisk og praktisk. Innen helse kan man for eksempel si at mens det å gi god omsorg har vært en kjerneverdi i sykepleie, så har det å behandle skader og sykdom være en kjerneverdi innen somatisk medisin.

Når det gjelder profesjonelt barnevernarbeid, som denne boken handler om, så er et spesielt trekk ved dette arbeidet at det i særlig stor grad har verdiladede kjernebegreper. Som det følger av barnevernloven paragraf

1 I hvor stor grad dette skjer. er til dels et teoretisk tema, blant annet i tilknytning til spørsmålet om mennesker kan være viljesvake, og i så fall hvordan de kan være det. I denne boken vil det ikke være nødvendig å ta stilling til spørsmålet om vi alltid handler i samsvar med det vi mener er det beste handlingsvalget.

Sitering av denne artikkelen: Nordby, H. \& Halsa, A. (2020). Introduksjon. I H. Nordby \& A. Halsa (Red.), Verdier i barnevern (Kap. 1, s. 9-23). Oslo: Cappelen Damm Akademisk. https://doi.org/10.23865/ noasp.103.ch1 Lisens: CC BY-ND 4.0 
1-1, er barnevernets grunnleggende samfunnsmandat «å sikre at barn og unge som lever under forhold som kan skade deres helse og utvikling, får nødvendig hjelp, omsorg og beskyttelse til rett tid» (barnevernloven [bvl.], 1992). Når barnevernsarbeidere kommer i kontakt med barn og unge i vanskelige livssituasjoner, må de gjøre vurderinger og avveininger ut fra prinsipper som hensynet til barnets beste, det biologiske prinsipp og det minste inngreps prinsipp (Christiansen \& Kojan, 2016; Eide, 2019). Disse prinsippene er normative. De angir grunnleggende føringer for hvordan barnevernet skal jobbe, samtidig som de må veies mot hverandre og vurderes i lys av de spesifikke livssituasjonene til barna, ungdommene og familiene barnevernet jobber med.

Målet med denne boken er å utdype noen av de mest sentrale måtene barnevernarbeid er forankret i normative verdibegreper på. I dette innledende kapitlet definerer vi en ramme for boken. I de to neste delene av kapitlet tydeliggjør vi hvordan barnevernets arbeid grunnleggende sett er verdiladet. Deretter klargjør vi kjernen av bokens analytiske innfallsvinkel, som de ulike bidragene tematiserer. I den siste delen gir vi en kort presentasjon av kapitlene.

\section{Verdibaserte rammer for barnevernets arbeid}

Dette er ikke en bok som gir en introduksjon til barnevernarbeid som profesjonsutøvelse. For gode nyere introduksjoner til hvordan barnevernet jobber og er organisert, se for eksempel den nylig utgitte boken Barnevernspedagog (Studsrød, Kvaran, Paulsen \& Mevik, 2019) eller Beslutninger i barnevernet (Christiansen \& Kojan, 2016). Det vi vil være opptatt av her, er hvordan rammene for barnevernarbeid i stor grad er verdibasert. For å kunne avklare hvordan vi forstår dette, må vi i første omgang si noe kort om hva det vil si at sosialfaglig praksis - som barnevern er en del av - er verdiladet.

Eide og Oltedal (2015, s. 85) formulerer viktig innledende distinksjon når de sier at «[s]osialt arbeid bygger på en rekke verdier - verdier som skal søkes realisert og gi mening i utøvelse av sosialt arbeid». Distinksjonen mellom det å realisere verdier og det at verdier skal gi mening, er viktig fordi den understreker at verdier ikke bare er overordnede mål 
barnevernet jobber mot, som å sikre at barn får god nok beskyttelse. Verdier er også noe man jobber med, når mål for godt faglig arbeid skal nås. De skal prege selve arbeidet. For eksempel er verdien av god kommunikasjon alltid viktig i barnevernsarbeideres samhandling med andre.

Både verdier man skal jobbe mot, og verdier man skal jobbe med, har en normativ rolle. De er handlingsveiledende. Barnevernsarbeidere kan for eksempel ikke selv velge om barn og unge skal medvirke i beslutningsprosesser, eller om familier i utgangspunktet skal møtes med respekt og forståelse. Det er forventet at disse hensynene ivaretas ut fra faglige, yrkesetiske og til og med juridiske prinsipper (Nordby, Bennin \& Buer, 2013).

\section{Verdier i barnevern}

Både når det gjelder verdier barnevernet jobber mot, og verdier de jobber med, kan man, mer generelt, si at barnevernets arbeid er verdiladet på tre grunnleggende måter.

\section{Verdiladede grunnbegreper knyttet til barns behov}

Barnevernet skal ivareta interessene til barn og unge ved å sørge for at de som er i spesielt vanskelige livssituasjoner, får nødvendig hjelp. Barnevernet har et spesielt mandat for å iverksette tiltak når det har oppstått et omsorgsproblem - når omsorgssituasjonen til et barn eller en ungdom ikke lenger er tilfredsstillende. Denne type problemfokusert arbeid er ikke forebyggende - i det minste ikke primærforebyggende. ${ }^{2}$

I lovverket, som angir en sentral ramme for barnevernets arbeid, er mandatet om å ivareta barn når det har oppstått et behov for hjelp, formulert en rekke steder. I barnevernlovens aller første paragraf 1-1 har nå et så grunnleggende begrep som kjærlighet blitt uthevet: «Loven skal bidra til at barn og unge møtes med trygghet, kjærlighet og forståelse»

2 Samtidig er barnevernets forebyggende arbeid eksplisitt beskrevet i barnevernloven paragraf 3-1: «Kommunen skal følge nøye med i de forhold barn lever under, og har ansvar for å finne tiltak som kan forebygge omsorgssvikt og atferdsproblemer. Barneverntjenesten har et spesielt ansvar for å avdekke omsorgssvikt, atferds-, sosiale og emosjonelle problemer så tidlig at varige problemer kan unngås, og sette inn tiltak i forhold til dette.» I hvor stor grad barnevernet kan og bør jobbe primærforebyggende, er et omdiskutert tema. 
(barnevernloven, 1992). Det er verdt å merke seg at mange av de verdiladede føringene i lovverket ikke er «kan»-formuleringer. Det vil si at det ikke er opp til hver enkelt profesjonsutøver om de ønsker å handle i samsvar med føringene. Å ivareta føringene anses som så viktig at barnevernsarbeidere har plikt til å gjøre det, i kraft av å være profesjonelle.

\section{Brutale avgjørelser og maktutøvelse}

Barnevernet kan, når det er begrunnet, bruke stor grad av makt. Dette skjer typisk når familier pålegges hjelpetiltak, når omsorgsovertakelse skjer mot foreldres vilje, eller når en ungdom plasseres på institusjon mot ungdommens vilje. Barnevernet representerer i seg selv strukturell og institusjonell makt (Nordstoga, 2004). Bare det å oppleve at barnevernet undersøker omsorgssituasjonen til et barn i en familie, kan av familien oppleves som stor grad av maktutøvelse.

Maktbruk krever alltid en spesiell begrunnelse. Det som vurderes som de positive konsekvensene av å anvende makt, også verbal makt, må oppveie det negative som ligger i det å bruke makt mot andre mennesker. Dette gjelder for så vidt i profesjonsutøvelse generelt. Mange andre profesjonsutøvere kan også, under gitte betingelser, anvende makt når det er nødvendig for å avverge svært negative konsekvenser.3 Det som kjennetegner barnevernets arbeid, er at det kan involvere stor grad av maktutøvelse, og at maktutøvelsen kan være særlig inngripende og sette dype spor (Westby, 2019).

\section{Et arbeid preget av skiftende ideologier}

Barnevern har ikke en konstant naturvitenskapelig kjerne, slik naturvitenskapene har hatt (i hvert fall de siste 150 årene). Selve grunnforståelsen av barnevern som fagområde - barnevernets ideologiske selvbilde - har endret seg (Ericsson, 1996). På mange måter er barnevern i seg selv et tverrfaglig fagområde, men hvordan denne tverrfagligheten forstås, har stadig endret seg.

3 Maktbruk kan være hjemlet på ulike måter i lovtekster for ulike profesjoner. I tillegg finnes det generelle juridiske prinsipper om nødrett og nødverge som åpner opp for maktbruk i helt spesielle situasjoner. 
Det siste tiåret har psykologi og spesielt utviklings- og tilknytningsteori fătt betydelig fotfeste i barnevern. For mye fotfeste, vil mange muligens si, og vi ser kanskje nå en dreining tilbake mot et mer helhetlig fokus på familiers totale livssituasjon, inkludert sosiale og økonomiske rammebetingelser for omsorg. Stadig flere av problemene familier har, forstås som komplekse, slik at de må løses gjennom betydelig tilpasning til den spesielle konteksten familien lever i (Fauske, Kvaran \& Lichtwarck, 2017).

Prinsipper om å ivareta barns rettigheter på en best mulig måte, og å sikre at barn har reell medvirkning i beslutninger, har også i større grad blitt fremhevet det siste tiåret. Det å kunne vise at barn og unge selv har deltatt $\mathrm{i}$ beslutninger, står stadig sterkere og faller inn under et mer generelt krav om at barnevernet må dokumentere og begrunne beslutninger (Helsetilsynet, 2019).

\section{Verdiladet skjønn}

I barnevernarbeid er det vanligvis ikke mulig å peke på en naturvitenskapelig «feil» eller et patologisk avvik fra en biologisk normalitetsnorm (som en vanlig somatisk sykdom eller fysisk skade) som begrunnelse for et tiltak. Barnevernsarbeidere må forholde seg til mange mindre håndfaste momenter i et barns omsorgssituasjon, og det kan også være stor grad av usikkerhet om hvordan de ulike momentene skal vektlegges. Det er ofte nødvendig å vurdere risiko og tenke helhetlig på en måte som gjør det utfordrende å redusere beslutningsgrunnlaget for en vurdering til et tydelig sett av premisser i et logisk argument. Vurderingen får dermed, i større eller mindre grad, en skjønnsmessig dimensjon.

I og med at kjernebegrepene i barnevernarbeid er så verdiladet, vil denne skjønnsmessige vurderingen ofte også være verdiladet. Hva vil det si at et barns omsorgssituasjon er god nok? Hvordan skal barnets beste interesser ivaretas? Og hva vil det si å møte et barn med kjærlighet slik dette faktisk er nevnt i barnevernloven paragraf 1-1? Den kjente norske jusprofessoren Torstein Eckhoff (1993, s. 125) understreket for mange år siden at all anvendelse av jus er basert på skjønn: «Selv om retningslinjene gir veiledning, kan de aldri gi definitive svar på hva den enkelte avgjørelse 
skal gå ut på. Det beror alltid på konkrete skjønnsmessige vurderinger.» Det at skjønnsutøvelsen er verdibasert, blir spesielt tydelig i barnevern fordi sentrale begreper i lovverket er så verdiladet, og fordi det er nødvendig å fortolke disse begrepene som handlingsveiledende for praksis.

I barnevernet forsterkes det verdiladede skjønnet ytterligere av at arbeidet må baseres på gode situasjonsforståelser. Det er vanskelig kun å bruke generelle prinsipper til å begrunne beslutninger. For en barnevernsarbeider kan situasjonsbasert, erfaringsbasert og implisitt kunnskap om hva det er riktig å gjøre, oppleves som avgjørende, men denne formen for etisk dømmekraft er vanskelig å formulere som ren påstandskunnskap (Nordby, Bennin og Buer., 2013). Ofte vil barnevernsarbeideres egne verdier og holdninger i stor grad påvirke vurderingene de gjør.

\section{Omfanget av skjønn}

Noen har ment at skjønnsutøvelse i barnevern bør minimaliseres så godt det lar seg gjøre, og at det er mulig å lage metodeverktøy og analysemodeller som i stor grad kan redusere subjektiv synsing rundt alvorlige beslutninger som har dyptgripende konsekvenser for barn og deres familier. Et eksempel på dette er utarbeidelsen av ulike systematiske metoder som brukes som hjelpeverktøy i barneverntjenester.

Metodeverktøy kan virke appellerende, og jo enklere de er, desto større kan entusiasmen bli over at de er greie å lære og anvende. Problemet, vil mange si, er at barnevern ikke er Rema 1000, og at vurderinger som fremkommer ved å bruke metodeverktøy, og spesielt metodeverktøyene som er enkle å forstå og bruke, kan gi et snevert og ufullstendig bilde av virkeligheten. Hvis man forstår barns helhetlige omsorgssituasjon gjennom et fåtall begreper, risikerer man å miste noe som er essensielt for å forstå hva som er riktig og galt (Nordby, Bennin og Buer 2013). Innvendingen vil være at hvis man tror at metodeverktøy er hovedressursen i barnevernfaglige begrunnelser, så tilpasser man landskapet til kartet og ikke omvendt, slik at man ikke finner løsninger til det som reelt sett er til barnets beste. I verste fall kan ukritisk bruk av enkle metodeverktøy forverre et barns omsorgssituasjon eller skape uheldige problemforståelser (Pettersvold \& Østrem, 2019). 
Litt av den samme utfordringen kan oppstå hvis man har et ensidig syn på hvordan praksiser skal være forskningsbasert. Tanken bak forskningsbasert praksis i barnevern har vært at hvis man står overfor et barn i en bestemt situasjon, og hvis det foreligger forskning om hva som er et godt tiltak for et barn i denne situasjonen, så kan dette tiltaket brukes. Problemet er bare at det på langt nær finnes forskning som dekker hele spekteret av omsorgsituasjoner der hjelp kan være nødvendig (Backe-Hansen, 2009). Utsatte barn og unge kan dessuten være i så ulike kontekster at det kan være vanskelig å anvende akkurat det vi vet fra forskning, på en god nok måte. I verste fall kan man gjøre ting verre fordi man ukritisk ser bort fra kontekstuelle faktorer som i virkeligheten gjør at eksisterende forskning ikke passer. Bare i vurderingen av hvordan eksisterende forskning passer med nye situasjoner, ligger det en betydelig grad av skjønnsutøvelse.

Det er viktig å understreke at dette ikke innebærer at forskning skal ha liten relevans i barnevernarbeid. Det innebærer heller ikke at barnevernsarbeidere ikke skal begrunne og dokumentere de valgene de gjør, så godt det lar seg gjøre. Poenget er at verdibasert skjønn også spiller en avgjørende rolle i de aller fleste beslutningsprosesser.

Til sjuende og sist er det er vanskelig å forstå hvordan faglig skjønnsutøvelse kan unngås i barnevernarbeid. Noen vil kanskje påstå at barnevernet i for stor grad gjemmer seg bak skjønnsbegrepet, men dette er på ingen måte opplagt. Det virker mer rimelig å tro at barnevernsarbeidere ikke bruker skjønn fordi de vil, men fordi de opplever at de faglig sett må. Harald Grimen har kalt baksiden av medaljen rundt bruk av skjønn for skjønnets byrde - det å ikke kunne redusere beslutningsgrunnlag fullt og helt til premisser i tydelige argumenter (Grimen \& Molander, 2008; Grimen, 2009). Skjønnets byrde gir nok en treffende karakteristikk av hvordan mange barnevernsarbeidere opplever det å anvende skjønn og dømmekraft.

\section{Kjernebegreper}

Det at barnevern som praksisområde er verdiladet på de måtene som nå er beskrevet, er ikke spesielt kontroversielt. Det ideologiske grunnlaget for barnevernets arbeid har vært diskutert i faglitteratur, og det har vært 
mye oppmerksomhet på hvordan barnevernet i Norge og andre land tolker og anvender verdiladede prinsipper som barnets beste. Noe det ikke har vært like mye oppmerksomhet rundt, er den mer teoretiske forstålsen av verdibegrepet i en barnevernfaglig kontekst.

Uttrykket «verdi» er ikke et ord som har entydig, hverdagslig mening. Vi kan snakke om at en handling har en verdiegenskap, som når vi sier «det var en god handling» og tillegger handlingen egenskapen godhet. Men ordet «verdi» kan referere til noe mer enn egenskaper ved handlinger. Et viktig mål med denne boken er å tydeliggjøre og problematisere flere forståelser av ordet. For å kunne forklare hvordan kapitlene gjør dette, må vi skille mellom tre verdibegreper.

\section{Samfunnsverdier}

Dette er grunnleggende størrelser som likhet, frihet, solidaritet og rettferdighet. De er typisk institusjonalisert og forankret i lovverk og overordnede prinsipper om menneskerettigheter. Det betyr ikke at alle godtar dem, men i det minste at svært mange vil godta dem som abstrakte begreper. Samfunnsverdier oppfattes gjerne som generelle. De aller fleste mener for eksempel at likestilling er en viktig overordnet verdi, og at likestilling bør være en viktig verdi for alle, ikke bare for en avgrenset gruppe i samfunnet.

Det at vi godtar mange av de samme samfunnsverdiene som generelle begreper, betyr ikke at det alltid er enighet om hvordan de skal fortolkes eller anvendes i praksis. Dette kan også drøftes i tilknytning til praktisk barnevern. For eksempel kan vi stille spørsmål ved den spesifikke anvendelsen av rettferdighet - om utsatte barn som vokser opp i en liten kommune, skal få tilgang til de samme tjenester som utsatte barn og unge i større sentrale kommuner med mange ansatte med spisskompetanse på ulike problemområder.

\section{Kulturelle verdier}

I tillegg til samfunnsverdier kan vi snakke om verdier som er grunnleggende viktige for en sosial gruppe, uten at de representerer eller forventes å representere alles preferanser. Personer som deler verdier, vil typisk oppfatte disse som en del av sin kulturelle identitet. Denne type verdier 
knyttes ofte til religion, etnisitet eller tradisjonelle levemåter, men brukes også i organisasjonsteori for å karakterisere profesjonskulturer og organisasjonskulturer (Schein, 2010). Det finnes kulturelle fellesskap knyttet til ideologiske overbevisninger, men også mer uformelle felleskap med mindre tydeligere kjerneverdier, som det for eksempel har vært vanlig å snakke om «ungdomskulturer» eller «bondekulturer». Generelt kan kulturelle verdier og kulturell identitet forstås på mange måter (Parker, 2000).

Barnevernets arbeid er i stor grad preget av skiftende kulturelle verdier, blant annet i tilknytning til spørsmål om oppdragelse, omsorg, kjønnsroller og forståelser av hva en god barndom og oppvekst er. Mange av disse verdiene vil fortolkes og anvendes i handling på noenlunde den samme måten i barnevernfaglige virksomheter, men det kan også utvikle seg særegne organisasjonskulturer ulike steder - «sånn gjør vi det her» (Schein, 2010). I tillegg jobber barnevernet tverrfaglig med profesjoner som har andre kulturelle og profesjonsspesifikke kjerneverdier enn det barnevernet har (Nordby, Bennin og Buer, 2013).

\section{Personlige verdipreferanser}

Det finnes et tredje verdibegrep som verken er samfunnsverdier eller kulturelle verdier. Våre personlige verdipreferanser er knyttet til hvert individ, uavhengig av om flere deler dem. Personlige verdier i denne forstand er individuelle holdninger og interesser, hva vi liker å gjøre i livet vårt. Disse verdipreferansene er individuelle eller sosiale aktiviteter som betyr mye for hver enkelt person. For noen har det høy verdi å være mye sammen med nærmeste familie, for andre er det mindre viktig. Noen er svært opptatt av å holde på med friluftsaktiviteter, andre er i mindre grad opptatt av å være utendørs.

Merk at denne forståelsen av personlige verdier som verdipreferanser er noe annet enn den forståelsen av personlig verdi som refererer til vår status som mennesker. Alle mennesker har egenverdi som individer. Dette er verdien av å være menneske. Men menneskeverdet vi har i kraft av å være mennesker, er noe annet enn verdipreferansene hver og en av oss har i vårt eget liv, som en individuell og handlende aktør. 
Det at personlige verdier ikke nødvendigvis deles i sosiale fellesskap, betyr selvsagt ikke at vi ikke deler mange av de samme verdipreferansene. Det at mennesker har mange felles grunnleggende verdipreferanser, kan nettopp forstås som en vesentlig del av forklaringen på hva det vil si å være i et kulturelt fellesskap. På samme måte er det en sammenheng mellom personlige verdier og samfunnsverdier. Hvis for eksempel bare en begrenset gruppe i befolkningen ga uttrykk for at de verdsetter å leve i et demokrati, ville ikke demokrati ha vært en samfunnsverdi.

Som allerede antydet er ikke grensen mellom verdibegrepene skarp. Spesielt gjelder det skillet mellom samfunnsverdier og kulturelle verdier. Verdier noen regner som samfunnsverdier, eller i det minste verdier mange mener bør være samfunnsverdier, kan av andre regnes som kulturelle verdier.

Samtidig må man ikke glemme at det finnes mange overordnede verdier det vil være søkt å kalle «bare» kulturelle verdier. Dette gjelder også mange av de verdiene som er nedfelt i norsk lovverk, menneskerettighetene og barnekonvensjonen (som er en del av norsk lovverk). Det kan jo finnes dem som ikke vil godta barnekonvensjonen, men det ville være urimelig å hevde at prinsippene i konvensjonen av den grunn ikke bør være allmenngyldige. Vi må også huske at når det er uenighet om generelle verdier, er det ofte fortolkningene som skaper splid, ikke de generelle begrepene i seg selv.

Dette er relevant i debatten om det norske barnevernet, som har fått stor plass i media. De siste årene har barnevernssaker blitt klaget inn for menneskerettighetsdomstolen i Strasbourg, og Norge har tapt flere av dem. Flere av sakene handler om foreldre som har mistet omsorgen for små barn og fått begrenset samvær. Foreldrene som har klaget inn sakene, mener at barnevernet har splittet opp familier, og at vurderingene som har vært gjort, ikke har ivaretatt barns og foreldres rett til familieliv. Kritikere av norske praksiser har ment at fortolkningen av «barnets beste» $\mathrm{i}$ for liten grad vektlegger betydningen av biologisk familie.

Det faller utenfor rammene her å vurdere denne kritikken. Poenget er bare at debatten illustrerer et viktig poeng: Selv om prinsipper som det å ivareta barnets beste er overordnet, så kan fortolkninger av prinsippene 
være farget av kulturelle fortolkningsrammer og potensielt skape uenighet og konfliktsituasjoner.

\section{Faglig og tematisk fokus}

Denne boken handler på ulike måter om samfunnsverdier, kulturelle verdier og personlige verdier, slik de er karakterisert over. Noen av kapitlene retter søkelyset mest på samfunnsverdier, andre hovedsakelig på kulturelle verdier og noen mer på personlige verdier. Et hovedmål med boken er å vise at verdibegrepene kan diskuteres på flere nivåer, med ulike faglige briller og fra ulike ståsteder. Noen av bidragene retter søkelyset mest på barnevernsarbeidernes verdivurderinger. Andre er mer opptatt av de institusjonelle rammene barnevernsarbeidere jobber innenfor. Vi ønsker å vise hvordan flerfaglige tilnærminger kan belyse mange sider ved barnevern som en verdiladet praksis, og samtidig få frem grunnlaget for kompleksiteten i vurderinger som gjøres.

Innenfor denne rammen er boken delt $\mathrm{i}$ to hoveddeler. Den første belyser hvordan ulike fagdisipliner kan bidra til å forstå hvordan barnevernarbeid er verdiladet. Kapitlene i denne delen bruker eksempler og anvendelsesområder for å konkretisere sine teoretiske bidrag og vise frem dilemmaer og grunnleggende utfordringer. Den andre delen av boken bygger mer på empirisk kunnskap. Kapitlene i denne delen diskuterer hvordan praksisnær kunnskap kan kaste viktig lys over problemstillinger knyttet til verdier og verdimotsetninger. To av bidragene retter oppmerksomheten spesielt mot læringsmodeller i utdanning ved å belyse hvordan studenter gjennom sin utdanning kan få trening i å reflektere over verdier i barnevernfaglig profesjonsarbeid.

I det første kapitlet i første hoveddel - kapittel 2 - drøfter Camilla Bennin hvilke rettsregler vi har om hensynet til barnets beste, og hvordan disse aktivt kan brukes som argumenter i barnevernssaker. Hun beskriver viktige endringer i barnevernloven og trekker også inn hvordan innholdet i barnekonvensjonen har betydning for fortolkningen av barnets beste. Sentrale elementer i dagens forståelse av barnets beste i Norge er tilknytnings- og relasjonskvalitet, biologiske bånd, minste inngreps prinsipp og barns medvirkning i beslutningsprosesser. 
I kapittel 3 er Grethe Netland opptatt av hvordan fortolkning av prinsippet om barnets beste og andre prinsipper barnevernet arbeider etter, kan komme i konflikt med allmennmoralske oppfatninger. I praktisk barnevernarbeid må ulike prinsipper ofte veies mot hverandre. Netland foreslår at filosofen John Rawls' idé om reflektert likevekt kan brukes som modell for hvordan barnevernet kan forholde seg til situasjoner der det foreligger grunnleggende motsetningsforhold mellom prinsipper, praksiser og rettferdighetsvurderinger.

Halvor Nordby diskuterer i kapittel 4 hvordan verdikonflikter kan oppstå i barnevernarbeid. Han bruker språkfilosofi til å forstå verdikonflikter og hvordan denne type konflikter kan håndteres. Kapitlet argumenterer for at verdipreferanser ikke refererer til verden på samme måte som tanker og oppfatninger, og at verdikonflikter derfor ikke kan løses ved å vise at noen verdier er objektivt usanne. Nordby hevder at ved å fokusere på verdiers roller i menneskers forståelseshorisonter, har barnevernsarbeidere bedre forutsetninger for å håndtere verdikonflikter til barns beste.

I kapittel 5 drøfter Mari Rysst profesjonsutøveres kulturelle verdier i møter med barn og foreldre fra minoritetskulturer. Ut fra et sosialantropologisk perspektiv er utgangspunktet hennes at vi alle er kulturbærere, og at vi handler ut fra ubevisste moralske forestillinger. Dette gjør vi automatisk uten å tenke over at vi faktisk utøver verdiladede praksiser. Med referanse til psykologisk antropologi og den franske filosofen Pierre Bourdieu bruker hun begrepet «kroppsliggjorte praksiser». Rysst drøfter hvordan bevissthet om slike praksiser kan være spesielt viktig for barnevernsarbeidere i møter med familier med etnisk minoritetsbakgrunn.

Lene Nygaard Solli diskuterer i kapittel 6 spenningsforholdet mellom barns rett til medvirkning og barns rett til beskyttelse og omsorg, som er to barnevernfaglige kjerneverdier nedfelt i barnevernloven. Når barnevernet bruker beslutningsmodellen familieråd, er dette nettopp et forsøk på å forene barnets rett til medvirkning med prinsippet om beskyttelse. Solli tar utgangspunkt i foreliggende forskning om familieråd, og hun drøfter om ulike perspektiver i denne forskningen bygger på premisser som kan anerkjenne spenningen mellom medvirkning og beskyttelse. I siste del av kapitlet argumenterer Solli for at forskning basert på Michel 
Foucaults maktanalyser, kan bidra til å problematisere og få frem denne spenningen.

I kapittel 7 - det første kapitlet i den mer empiriske delen av boken retter Kerstin Söderström søkelyset mot verdispenninger som kan oppstå i tverrprofesjonelt barnevernarbeid. Söderström er særlig opptatt av profesjonskulturer og viser hvordan barnevernfaglig arbeid ofte har, og må ha, et tverrprofesjonelt fokus i alvorlige saker der omsorgsovertakelse kan være aktuelt. Profesjonsutøvere som skal samarbeide i denne type situasjoner, kommer til samarbeidsmøter med ulike mandat, posisjoner og verdibaserte holdninger. Söderström bruker en kaustikk for å synliggjøre hvordan verdikonflikter kan utspille seg i en situasjon om omsorgsovertakelse av nyfødte barn.

Astrid Halsa fokuserer i kapittel 8 på barns og unges erfaringer med barnverntjenesten. Mens kapitlene presentert ovenfor har et profesjonsperspektiv, bygger dette kapitlet på intervjuer med ungdom og unge voksne som har vært i kontakt med barnevernet. Informantene har vokst opp i hjem hvor foreldrene har hatt alvorlige rus- eller psykiske helseproblemer. Gjennom historiene de forteller, kommer det tydelig frem hvor vanskelig det er for dem å finne veien til hjelpeapparatet og barnevernet spesielt. Informantene opplever at hvis de tar kontakt med barneverntjenesten, svikter de sine foreldre, de ødelegger familien sin, og de risikerer å måtte bryte bånd til familiemedlemmer de føler sterk tilhørighet til. Kapitlet bruker sosiologiske perspektiver for å få frem den sterke verdien familietilknytning har, også blant dagens unge.

I kapittel 9 beskriver Kerstin Söderström og Anders Sandvig jr. et undervisningopplegg hvor studenter og fagpersoner ble koblet sammen for å trene på å samarbeide om alvorlig bekymring for et nyfødt barn. Målet var å utforske en simuleringsmodell for opplæring, praksis- og fagutvikling som kan bidra til økt bevissthet om egne profesjonsverdier og $ø$ kt kompetanse i tverrfaglig praksis innen spedbarnevern og foreldrestøtte. Sandvig og Söderström konkluderer med at simulering som praksisnær undervisningsform med høy grad av studentaktivitet kan ha stor pedagogisk verdi.

Liv Randi Roland diskuterer i kapittel 10 hvordan studenter kan oppdage og lære om egne og andres kulturelle verdier og praksiser gjennom 
å påta seg å være mentorer for migrasjonsbarn i norske skoler. Undervisningsopplegget Roland retter søkelyst mot er del av den nasjonale satsingen Nattergalen, som har et tydelig fokus på barnevern. Roland er særlig opptatt av at studentene som har erfaringer med å møte barna, får innsikter i familiekulturer og i hvordan oppvekstbetingelsene er for minoritetsbarn i Norge. Hun peker på at det å lære å forstå og verdsette egne og andres verdier er læringsprosesser som forutsetter andre typer undervisning enn den som foregår i klasserommet.

\section{Litteratur}

Backe-Hansen, E. (2009). Hva innebærer et kunnskapsbasert barnevern? Fontene forskning, (2), 4-16.

Barnevernloven (1992). Lov om barneverntjenester (LOV-1992-07-17-100). Hentet fra https://lovdata.no/dokument/NL/lov/1992-07-17-10o?q=barnevernloven

Christiansen, Ø. \& Kojan, B. H. (2016). Beslutninger i barnevernet. Oslo: Universitetsforlaget.

Christoffersen, S. A. (2011). Profesjonsetikk. Om etiske perspektiver i arbeidet med mennesker (2. utg.). Oslo: Universitetsforlaget.

Eckhoff, T. (1993). Rettskildeloere (3. utg.). Oslo: TANO.

Eide, S. B. \& Oltedal, S. (2015). Verdiers betydning for vår forståelse og vår handling. I I. T. Ellingsen, I. Levin, Berg, B. \& L. C. Kleppe (Red.), Sosialt arbeid. En grunnbok (s. 80-96). Oslo: Universitetsforlaget.

Eide, S. B. (2019). Etikk i barnevernet. I I. Kvaran, I. Studsrød, V. Paulsen \& K. Mevik (Red.), Barnevernpedagogen (s. 66-77). Oslo: Universitetsforlaget.

Ericsson, K. (1996). Barnevern som samfunnsspeil. Oslo: Pax.

Fauske, H., Kvaran, I. \& Lichtwarck, W. (2017). Hjelpetiltak i barnevernet. Komplekse problemer og usikre virkninger. Fontene Forskning 2(10), 45-58.

Grimen, H. \& Molander, A. (2008). Profesjon og skjønn. I A. Molander \& L. I. Terum (Red.), Profesjonsstudier. Oslo: Universitetsforlaget.

Grimen, H. (2009). Skjønn som resonneringsform. I T. Skauge (Red.), Profesjonsledelse og kunnskapsorganisering, Bergen: FORPRO.

Helsetilsynet. (2019). Det å reise vasker øynene. En gjennomgang av 106 barnevernsaker. (Rapport 17.01.2019) Hentet fra https://www.helsetilsynet.no/globalassets/ opplastinger/publikasjoner/rapporter2019/helsetilsynet_rapport_unummerert_ gjennomgang_106_barnevernsaker.pdf

Nordby, H., Bennin, C. \& Buer, B. A. (2013). Etikk i Barnevern. Oslo: Gyldendal Akademisk. 
Nordstoga, S. (2004). Barnevernarbeiderens makt. I T. Havik, S. Nordstoga, M. Y. Larsen \& J. Veland (Red.), Barnevernet: Forutsetninger og gjennomføring (s. 119126). Oslo: Universitetsforlaget.

Parker, M. (200o). Organizational culture and identity. London: SAGE.

Pettersvold, M. \& Østrem, S. (2019). Problembarna. Oslo: Cappelen Damm Akademisk.

Schein, E. H. (2010). Organizational culture. (4 utg.). San Francisco, CA: Jossey-Bass.

Westby, L. (2019). Makt og tvang - Skjult maktutøvelse i barnevernsinstitusjon. I I. Studsrød, I. Kvaran, V. Paulsen \& K. Mevik (Red.), Barnevernspedagog: En grunnbok (s. 171-182). Oslo: Universitetsforlaget.

Studsrød, I., Kvaran, I., Paulsen, V. \& Mevik, K. (2019). Barnevernspedagog: En grunnbok. Oslo: Universitetsforlaget. 



\title{
Barnets beste som juridisk argument i begrunnelser og beslutninger i barnevernet
}

\section{Camilla Bennin}

\author{
Høgskolelektor, Høgskolen i Innlandet
}

\begin{abstract}
This chapter discusses the rules of law that apply when considering the best interests of the child, and how these may actively be used as arguments in a Child Protection Services (CPS) case. The primary focus is linked to the Child Welfare Act and the decisions and justifications of the CPS; however, the goal has also been to look at the national rules in the context of human rights. This applies particularly to the best interests of the child as a basic value of the UN Convention on the Rights of the Child. To understand an area of law it may also be necessary to have insight on the developments in this field. Discussions are being raised about making the quality of attachment a principle in its own right, about the child's independent right to child protection services and the child's right to participate and have influence. New challenges have been raised in the wake of decisions by the ECHR, where several judgments have been quite critical of Norwegian child protection practices. The impending new Child Welfare Act in Norway will affect CPS' legal basis for the decisions it makes in the future. There is much to indicate that we are living in a time when the different interpretations of the best interests of the child are emerging more clearly.
\end{abstract}

Keywords: the best interests of the child, Child Protection Services (CPS), Child Welfare Act, UN Convention on the Rights of the Child

\section{Innledning}

Barn har et selvstendig krav på rettssikkerhet i møte med beslutninger fattet av barnevernet, og som gjelder dem. Jeg vil i dette kapitlet gi

Sitering av denne artikkelen: Bennin, C. (2020). Barnets beste som juridisk argument i begrunnelser og beslutninger i barnevernet. I H. Nordby \& A. Halsa (Red.), Verdier i barnevern (Kap. 2, s. 25-48). Oslo: Cappelen Damm Akademisk. https://doi.org/10.23865/noasp.103.ch2

Lisens: CC BY-ND 4.0 
en kort fremstilling av hvilke rettsregler vi har om barnets beste, både i barnevernloven og i menneskerettighetene. Målet er også å vise hvordan hensynet til barnets beste mer effektivt kan brukes som argument i begrunnelser og beslutninger i barnevernet.

Barnevernretten er i stadig endring, og både Den europeiske menneskerettsdomstolen (EMD) og norsk Høyesterett har nå i løpet av forholdsvis kort tid tatt standpunkt til sentrale og prinsipielle spørsmål innen dette lovområdet. Det norske barnevernet har på denne måten trådt frem og blitt belyst på et nivå som er helt nytt for dette feltet, noe som understreker behovet for en grunnleggende forståelse av «barnets beste»-begrepet.

Kravet til rettssikkerhet innebærer for det første at avgjørelsen materielt sett skal være riktig. I juridisk terminologi betyr dette for eksempel at avgjørelsen har et innhold som gir barnet det det eventuelt har rett på. For det andre må barnevernet sikre at avgjørelsen fattes på riktig måte, altså at saksbehandlingsreglene følges (Bernt \& Rasmussen, 2010, s. 47). Barnevernet må derfor kunne argumentere juridisk for de begrunnelsene som ligger forut for de beslutningene som fattes, enten av barnevernet selv eller av fylkesnemnda for barnevern og sosiale saker, som avgjør tvangssakene i barnevernet i første instans.

Hensynet til barnets beste er et sentralt prinsipp for alle profesjoner som jobber med barn. I norsk barnevern er dette en grunnverdi som skal tillegges «avgjørende vekt». Barnekonvensjonen slår fast at barnets beste skal være «a primary consideration», og ifølge EMD er dette av «paramount importance». Som Stang (2007, s. 30) uttrykker det, reflekterer prinsippet om barnets beste på mange måter den verdien barnet har for oss som samfunnsgode - kanskje det største samfunnsgodet vi har. Dette innebærer også at barn ikke kun har en nytteverdi. De har verdi i seg selv, akkurat slik de er.

«Barnets beste» er likevel ingen fast verdinorm som gir en konkret beskrivelse av regelens innhold. Begrepet bygger på normer som er en del av den alminnelige samfunnsutviklingen i synet på barn, og som endrer seg over tid. Lovgiver har derfor valgt å bruke dette skjønnsmessige begrepet i loven for å fange opp de samfunnsendringene som er relevante for den konkrete rettsanvendelsen til enhver tid. Når begrepet om barnets beste er normativt og vagt, fylles det med innhold avhengig av 
hvilket faglig ståsted man har, og med våre egne, personlige oppfatninger. Det er derfor alltid en mulighet for at en henvisning til barnets beste gir avgjørelsen en legitimitet som det ikke er faktisk grunnlag for (Haugli, 2020, s. 56). Det er altså vanskelig å trekke tydelige grenser for hva barnets beste innebærer, og det gjør det desto viktigere at barnevernet er bevisst dette begrepet i sine begrunnelser. Som fremstillingen under vil vise, er barnets beste likevel ikke så vagt som mange antyder, men har et juridisk innhold som til en viss grad er konkretisert gjennom konvensjoner, nasjonal lovgivning og rettsavgjørelser, og som angir kjernen i begrepet.

Det er ikke bare begrepets innhold som kan være utfordrende å kartlegge. Det er når hensynet til barnets beste skal avveies mot andre grunnleggende hensyn, som foreldres rett til familieliv, at begrepets skjønnsmessige karakter mer tydelig blir satt i bevegelse. I denne bokens kapittel 3 diskuterer Netland hvordan fortolkning av prinsippet om barnets beste - og andre prinsipper barnevernet arbeider etter - kan komme i konflikt med hverandre og med allmennmoralske oppfatninger. Netland foreslår at filosofen John Rawls' idé om reflektert likevekt kan brukes som modell for hvordan barnevernet kan forholde seg når grunnleggende prinsipper, praksiser og rettferdighetsvurderinger kommer i utakt (s. 49-67). På denne måten kan en juridisk og filosofisk tilnærming sammen gi en mer helhetlig forståelse av kompleksiteten når ulike grunnleggende verdier står på spill.

Før jeg går nærmere inn på innholdet av barnets beste, vil jeg gi en kort oppsummering av de siste endringene i barnevernloven som er relevante for «barnets beste»-vurderingen.

\section{Barnevernloven i endring}

Dagens barnevernlov er fra 1992, og over tid har behovet for å få en barnevernlov som er mer tidsriktig, blitt presserende. I 2016 avga barnevernlovutvalget sitt forslag til ny lov i NOU 2016: 16. Målet for utvalget var gjennom sitt lovforslag å bedre rettssikkerheten for barn og å skape et mer tilgjengelig, forståelig og tidsriktig regelverk. Dette er i stor grad fulgt opp i høringsnotatet om forslag til ny barnevernlov fra Barne- og likestillingsdepartementet (2019). 
Når det gjelder prinsippet om barnets beste, er dette også grundig behandlet både i NOU-en og i høringsnotatet. Barne- og likestillingsdepartementet hadde i 2012 fått utredet «det biologiske prinsipp» i barnevernet, der Raundalenutvalget foreslo et nytt overordnet hensyn kalt «det utviklingsstøttende tilknytningsprinsipp» (NOU 2012: 5). På bakgrunn av dette utvalgsarbeidet ble det foreslått flere endringer i barnevernloven, som blant annet innebar at vi fikk nye rettsregler med en sterkere oppmerksomhet på barns rett til medvirkning i barnevernet. Barnevernloven (bvl.) paragraf 4-1 om hensynet til barnets beste fikk i denne sammenheng et nytt andre ledd. I tillegg ble barnets rettsstilling forsterket gjennom en ny bestemmelse i barnevernloven paragraf 1-4, om at barnevernets tjenester og tiltak skal være forsvarlige.

I kjølvannet av NOU 2016: 16 har departementet valgt en tosporet løsning, der det arbeides med ny barnevernlov samtidig som det gjøres endringer i dagens barnevernlov (Prop. 169 L (2016-2017)). Disse endringsforslagene i barnevernloven trådte i kraft 1. juli 2018, og de fleste av endringene har direkte eller mer indirekte betydning for forståelsen av barnets beste. Etter barnevernloven paragraf 1-5 har barn nå en selvstendig rett til nødvendige barneverntiltak på lik linje med den retten barn har til andre velferdstjenester. Denne retten for barn har vært tematisert i mange år, og ulike offentlige utredninger som har foreslått å rettighetsfeste barneverntjenester, har møtt motbør (Lindboe, 2012, s. 27-28). Man mente det var problematisk å gi en rett til tvang, og at en slik rett også var unødvendig, idet barneverntjenesten uansett hadde en plikt til å yte hjelp hvis vilkårene var oppfylt. I tillegg ble en slik rett sett på som en uforutsigbar utgiftsøkning på grunn av fare for at søknader fra foreldre om hjelp til barnet ville øke. Nå har lovgiver kommet frem til at barn skal ha en rett på nødvendige tjenester og tiltak etter barnevernloven. Det har gradvis utviklet seg en oppfatning om at rettighetsfesting for barn i barnevernet vil være med på å styrke barnets rettsstilling. Dette innebærer også en harmonisering med velferdsretten for øvrig, og det kan være med på å gjøre barn mer bevisst på seg selv som rettighetsperson (NOU 2016: 16, s. 81).

Lovregelen om barnets rett til å medvirke er flyttet fra paragraf 4-1 og er nå nedfelt i paragraf 1-6. Barnevernet er også pålagt en plikt til å 
samarbeide med barn og foreldre, jamfør paragraf 1-7. Selv om samarbeid med familien kan være krevende å oppnå, skal barnevernet likevel tilstrebe et samarbeid i alle saker på en måte som er til barnets beste (Prop. 169 L (2016-2017) s. 142). Her legger departementet vekt på at også der barnevernet ikke er enig med barn eller foreldre, skal familien likevel anerkjennes og respekteres for deres synspunkter og behov. I formålsbestemmelsen i barnevernloven paragraf 1-1 har man nå tatt inn i lovteksten at barn i barnevernet skal møtes med trygghet, kjærlighet og forståelse. Dette er også i tråd med formuleringen i barnekonvensjonens fortale. Ifølge departementet har kjærlighetsbegrepet «en viktig symbolsk verdi og signaliserer en forventning om hvordan ansatte i barnevernet skal møte barn i barnevernet» (Prop. 169 L (2016-2017) s. 6).

En endring som også er knyttet til hensynet til barnets beste, er nye regler om krav til dokumentasjon i saksbehandlingen. Ulike tilsyn og forskningsrapporter viser at en rekke barneverntjenesters håndtering av meldinger og undersøkelser kan være svært vilkårlig, og at de ikke alltid forholder seg til lovens vilkår (Helsetilsynet, 2012, 2019; Lurie, Kvaran, Tjelflaat \& Sørlie, 2015, s. 33). Henleggelse av melding og undersøkelse skal derfor nå være skriftlig og faglig begrunnet, og henleggelse av undersøkelser skal dessuten regnes som enkeltvedtak som kan påklages, jamfør paragraf 4-2 og 4-3. I alle vedtak etter barnevernloven skal det etter de siste lovendringene også klart fremkomme hva som er barnets synspunkt, hvilken vekt barnets mening er tillagt, og hvordan barnets beste er vurdert. Dette gjelder både barneverntjenestens vedtak og de vedtak som fattes i fylkesnemnda, jamfør ny paragraf 6-3 bokstav a og paragraf 7-19 tredje ledd.

Forutsetningen for å sette inn tiltak etter barnevernloven er at man først må slå fast at lovens grunnvilkår for tiltak er til stede. Deretter gjør man en avsluttende, helhetlig og skjønnsmessig vurdering av om dette tiltaket er til barnets beste (Ofstad \& Skar, 2015, s. 65-66). Denne skjønnsmessige vurderingen er altså en vurdering som kommer til slutt, etter at grunnvilkårene er vurdert oppfylt. I særdomstolsutvalget, som har utredet nye domstolsordninger i barnevernet, vises det til at dette utgangspunktet nok er mer teoretisk, ettersom barnets beste ofte også preger tolkningen av for eksempel vilkårene for omsorgsovertakelse og 
også gjennom subsumsjonen om vilkåret faktisk er oppfylt (NOU 2017: 8, s. $60-61)$.

Man kan gjennom tilsynsrapporter og forskning få inntrykk av at det er noe ulik praksis i de forskjellige barneverntjenestene med tanke på hvor eksplisitt en slik vurdering av barnets beste i dag fremstår i vedtakene. I Helsetilsynets rapport (2019) løftes det blant annet frem noen funn knyttet til barneverntjenestens beslutningsprosesser. Her rettes søkelyset mot uklar dokumentasjon, manglende evaluering av hjelpetiltak og manglende alternative forståelsesmåter av familiens problemer, som gjør en reell «barnets beste»-vurdering vanskelig. Det vises også til utfordringer knyttet til vekting av barnets synspunkter (Helsetilsynet, 2019, s. 114).

Barnevernlovutvalget er av en oppfatning at en plikt til å synliggjøre barnets medvirkning og hvordan barnets beste er vurdert, vil bidra til å ansvarliggjøre barneverntjenesten og fylkesnemnda (NOU 2016: 16, s. 55). Det er derfor grunn til å tro at bedre begrunnede avgjørelser også innebærer at det gjøres valg som i større grad er til det konkrete barnets beste.

Antakelig har det nok også større betydning enn antydet av særdomstolsutvalget at barnets beste ikke er et uttalt vilkår for tiltak, for eksempel et tiltak som omsorgsovertakelse. Man kunne ha sett for seg at barnets beste var et mer eksplisitt uttalt vilkår for alle tiltak i barnevernet, slik vi finner det i vilkårene for adopsjon i barnevernloven paragraf 4-20. Her er det presisert $i$ tredje ledd bokstav b at forutsetningen for fylkesnemndas samtykke til adopsjon i foreldrenes sted, er at denne adopsjonen vil være til barnets beste. Det kan se ut som jo tydeligere lovgivningen er på betydningen av barnets beste, desto mer sannsynlig er det at dette hensynet konkret blir vurdert og får den avgjørende vekt som loven forutsetter.

Spørsmålet blir da hva barnets beste innebærer, med et juridisk perspektiv, og hvordan dette prinsippet skal vektlegges i en barnevernssak.

\section{Gjeldende rett om prinsippet om barnets beste i barnevernet}

Innenfor den norske barnevernretten er prinsippet om barnets beste regulert gjennom både Grunnloven, det alminnelige lovverket samt 
internasjonale konvensjoner. Prinsippet har videre blitt tolket og presisert gjennom forarbeider til blant annet barnevernloven, gjennom høyesterettspraksis og avgjørelser i menneskerettsdomstolen (EMD). I tillegg utgir FNs barnekomité (som har ansvar for å kontrollere at land som har skrevet under barnekonvensjonen, etterlever denne) generelle kommentarer om tolkningen av barnekonvensjonen. Komiteens uttalelser vil derfor også være viktige retningslinjer ved tolkningen av barnekonvensjonen, herunder prinsippet om barnets beste. Til tross for at prinsippet er av en slik karakter at det unndrar seg en klar definisjon og en entydig forståelse, vil disse rettskildene kunne bidra til at vi langt på vei kan gi «barnets beste»-begrepet et juridisk innhold. Dette innebærer også at disse rettskildene er både viktige og nødvendige argumenter i begrunnelser og beslutninger i barnevernet. Høyesterett har nå også klart uttalt at den i tidligere saker har lagt stor vekt på barnekomiteens generelle kommentarer om barnets beste (HR-2020-661-S avsnitt 80).

\section{Barnets beste og menneskerettighetene}

Menneskerettighetene er altså viktige kilder for å forstå og anvende rettsregler i barnevernet. Gjennom menneskerettsloven av 1999 har Norge implementert en rekke av disse menneskerettighetskonvensjonene, herunder blant annet Den europeiske menneskerettighetskonvensjonen (EMK) av 1950 og barnekonvensjonen (BK) av 1989. Disse bestemmelsene går foran annen lovgivning hos oss hvis det er motstrid, jamfør menneskerettsloven paragraf 3. EMK har ingen uttrykkelig bestemmelse om barnets beste, men prinsippet har stor betydning for hvordan EMD argumenterer i saker som gjelder barn. EMD er Europarådets menneskerettighetsdomstol og behandler klager fra individer mot staten for brudd på EMK gjennom en rettslig bindende dom (Høstmælingen, 2012, s. 386). Her har EMDs praksis lenge beveget seg mot å gjøre barnets beste mer og mer fremtredende (Sørensen, 2016, s. 318).

Barnets beste er imidlertid uttrykkelig regulert i barnekonvensjonen artikkel 3 nummer 1, som lyder: «Ved alle handlinger som berører barn, enten de foretas av offentlige eller private velferdsorganisasjoner, domstoler, administrative myndigheter eller lovgivende organer, skal barnets beste være et grunnleggende hensyn». 
Barnekomiteen har ved tolkningen av artikkel 3 uttalt at bestemmelsen for det første må forstås som en selvstendig rettighet for det enkelte barn som er «en iboende forpliktelse for statene, er direkte anvendelig (selvutførende) og kan påberopes for en domstol» (FNs barnekomité, 2013, generell kommentar nr. 14 avsnitt 6). Som Sørensen (2016, s. 315) konkluderer, «er det hevet over enhver tvil at også prinsippet innebærer en rettslig plikt til å tillegge barnets beste den nødvendige vekt, både ved gjennomføringen av andre rettigheter og når en lov som berører barn åpner for skjønn». Ifølge barnekomiteen har det «skjedd et paradigmeskifte fra en tilnærming der barn blir sett på som objekter som trenger hjelp, til en oppfatning av barn som en rettighetshaver som har en umistelig rett til beskyttelse» (FNs barnekomité, 2011, generell kommentar nr. 13 avsnitt 59).

Samtidig er barnet et menneske som helt og fullt er avhengig av voksne for å overleve og utvikle seg på en god måte, og barn trenger voksne som i ulik grad i oppveksten kan ivareta de rettighetene barn har. Normalt er det foreldrene som har ansvaret for å dekke barnets behov for omsorg, men der barnet utsettes for omsorgssvikt, kan det offentlige måtte overta dette ansvaret for å gi barnet nødvendig omsorg og beskyttelse. Gjennom prinsippet om barnets beste gir norsk lovgivning og internasjonale konvensjoner barnevernet det formelle grunnlaget for å behandle barn som et selvstendig rettighetssubjekt. Barnevernet har dermed en sentral rolle for nettopp å ivareta og styrke rettsstillingen til de mest utsatte barna gjennom de begrunnelser og avgjørelser de fatter.

Barnekomiteen har for det andre uttalt at barnets beste er et grunnleggende fortolkningsprinsipp. Dette innebærer at "[h]vis en juridisk bestemmelse er åpen for mer enn én tolkning, skal den tolkningen som mest effektivt tjener barnets beste velges» (FNs barnekomité, 2013, generell kommentar nr. 14 avsnitt 6). Barnekonvensjonen bygger på fire generelle prinsipper som utgjør kjerneverdiene i barnekonvensjonen. Hensynet til barnets beste (artikkel 3), retten til ikke-diskriminering (artikkel 2), retten til liv, overlevelse og utvikling (artikkel 6) og retten til å bli hørt (artikkel 12) henger sammen og utgjør en helhet. Barnekonvensjonen må derfor forstås slik at barnets beste «ikke bare etablerer en rettighet i seg selv, men at den også skal tas hensyn til ved fortolkning og gjennomføring av alle andre rettigheter» (FNs barnekomité, 2009, generell kommentar nr. 12 avsnitt 2). 
For det tredje er barnekonvensjonens artikkel 3 en prosedyrebestemmelse og saksbehandlingsregel, jamfør generell kommentar nr. 14. For barnevernets del medfører dette at avgjørelsen som fattes, må vise at barnets interesser er identifisert. Dette betyr likevel ikke at hensynet til barnet er det eneste hensynet som skal vektlegges jamfør Rt-2012-1985 avsnitt 134-136. I denne dommen fra Høyesterett gjaldt saken gyldigheten av et vedtak fra Utlendingsnemnda, hvor en iransk familie med barn som hadde bodd i Norge i lang tid, ble utvist. Til tross for at artikkel 3 om barnets beste her tilsa at familien skulle få bli i Norge, måtte dette vurderes opp mot innvandringsregulerende hensyn. Høyesterett uttalte at så lenge Utlendingsnemndas vedtak viste at hensynet til barnet var forsvarlig vurdert og avveid mot motstående hensyn samt tillagt vekt som et grunnleggende hensyn, var det ikke grunnlag for å sette vedtaket til side. Det er her viktig å understreke at det var avgjørende at Utlendingsnemnda her nettopp hadde tillagt hensynet til barnets beste stor vekt, ikke bare som ett av flere momenter i en helhetsvurdering. I denne konkrete saken måtte barnets beste altså likevel vike. I en nyere avgjørelse fra Høyesterett (Rt-2015-93) ble resultatet det motsatte. I denne saken satte Høyesterett til side et vedtak om utvisning av en kenyansk mor med en datter på fem år, som også var norsk statsborger. I avsnitt 65 fremhever Høyesterett nettopp at barnets interesser skal danne utgangspunktet, herunder at det må «løftes frem og stå i forgrunnen».

Høyesterett har også ved flere anledninger vurdert hensynet til barnets beste i barnevernloven, blant annet spørsmål om tvangsadopsjon. Tvangsadopsjon er dypt inngripende for alle parter og innebærer et endelig brudd med de familiemessige båndene. I Rt-1015-110 avsnitt 46 formulerer Høyesterett at «Foreldrenes interesser må, på den annen side, vike der avgjørende forhold på barnets hånd tilsier adopsjon ...».

\section{Kritikk mot norsk barnevern og aktuelle rettsavgjørelser om barnets beste}

Det norske barnevernet har de siste årene møtt internasjonal kritikk, særlig knyttet til omsorgsovertakelse, samvær og tvangsadopsjon. Dette har blant annet medført at EMD besluttet å behandle uvanlig mange barnevernssaker fra Norge. Den saken som har vekket størst oppsikt, er Strand 
Lobben-saken (37283/13). Her gjaldt det spørsmål om tvangsadopsjon av en gutt som var omsorgsplassert fra han var tre uker gammel. Spørsmålet var om tvangsadopsjon i dette tilfellet var en krenkelse av EMK artikkel 8 , som omhandler retten til respekt for privatliv og familieliv. Norge fikk først medhold i denne saken i EMD i 2017 med dissens 4-3. Er saken av tilstrekkelig prinsipiell karakter, kan den gå videre til EMDs storkammer, og Strand Lobben-saken ble behandlet i storkammeret med dom avsagt 10. september 2019. Her kom 13 av 17 dommere frem til at Norge hadde krenket EMK artikkel 8. Flertallet la særlig vekt på mangler ved sakens prosessuelle sider og det bevisgrunnlaget som det norske rettssystemet hadde bygget på i adopsjonssaken. Saken utfordrer det norske barnevernet med hensyn til hvor godt de klarer å begrunne de langsiktige omsorgsovertakelsene og begrensninger i samværet, med den følge at tilbakeføring til foreldrene blir nærmest umuliggjort. Denne avgjørelsen viser også at det er spenninger både innad i EMD og mellom EMD og norsk praksis om hvordan man skal vekte verdien av de biologiske båndene opp mot beskyttelse av barnet.

På bakgrunn av Strand Lobben-saken og andre fellende dommer i EMD besluttet derfor norsk Høyesterett å behandle felles tre nylig henviste barnevernssaker i Høyesteretts storkammer. I storkammeret settes Høyesterett med elleve dommere i stedet for fem, og dette gjøres kun i saker av særlig viktighet. Det gjaldt to saker om ankenektelse i lagmannsretten og en anke over dom. Sakene omhandlet adopsjon, omsorgsovertakelse og fastsettelse av samvær.

Den første og kanskje mest prinsipielle avgjørelsen gjaldt forholdet om lagmannsretten skulle ha gitt samtykke til behandling av foreldrenes anker over tingrettens dom om fratakelse av foreldreansvar og adopsjon (kjennelse av 27. mars, HR-2020-661-S). Slikt samtykke kan blant annet gis hvis det er vesentlige svakheter ved tingrettens avgjørelse, og Høyesteretts syn i denne saken var at det forelå slike vesentlige svakheter. Det ble særlig lagt vekt på at det var skjedd positive endringer i mors situasjon, og at det heller ikke var «foretatt noen inngående vurderinger av hvilken betydning de positive endringene i mors situasjon har for hennes omsorgsevne for datteren i dag» (avsnitt 194). I den enstemmige kjennelsen kom Høyesterett til at det ikke forelå noen motstrid mellom EMDs praksis og de generelle materielle og prosessuelle prinsippene ved adopsjon etter barnevernloven. 
Men Høyesterett understreker generelt at det er særlig viktig å følge prinsippene om barnevernets plikt til å arbeide for gjenforening, blant annet ved konkrete og grundige vurderinger om tilstrekkelig samvær og hjelpetiltak. Vedtakene «må bygge på et tilstrekkelig og oppdatert beslutningsgrunnlag, inneholde en balansert og tilstrekkelig bred avveining og ha en tilfredsstillende begrunnelse» (avsnitt 170-171). Når det gjelder hensynet til barnets beste, uttaler Høyesterett generelt at «barnet kan etter omstendighetene ha interesser som strider mot foreldrenes, og deres interesser må da vike for avgjørende forhold på barnets hånd» (avsnitt 82).

I den andre avgjørelsen, som er en dom (HR-2020-662-S), opprettholdt Høyesterett omsorgsovertakelsen, men økte samværet fra fire til åtte ganger i året. Det fremheves at det ikke kan stilles opp noen standardnorm for hvilket omfang samværet skal ha, men at dette må vurderes konkret fra sak til sak, med utgangspunkt i gjenforeningsmålet (avsnitt $130 \mathrm{og}$ 137). Både i Høyesterettsdommen og i praksis fra EMD blir gjenforeningsmålet særlig fremhevet, men samværet kan likevel ikke utsette barnet for en urimelig belastning («undue hardship»). Sandberg (2020b) løfter opp et viktig spørsmål i sine kommentarer til dommen, om det er riktig å gi samvær helt opp mot barnets tålegrense, fremfor å fastsette et samvær som etter en helhetsvurdering er til barnets beste. I den siste kjennelsen om omsorgsovertakelse og samvær kom Høyesterett til at ankene fra begge foreldrene skulle forkastes (HR-2020-663-S).

I tiden fremover vil derfor hensynet til barnets beste bli gjenstand for ny oppmerksomhet i norsk barnevern. Særlig gjelder dette hvordan de grunnleggende verdiene knyttet til rett til familieliv og barnets beste skal avveies på en måte som ikke er krenkelse av menneskerettighetskonvensjonen, og heller ikke i strid med den forskningsbaserte forståelse av hva som er til barns beste, og som norsk barnevernlovgivning i dag bygger på.

\section{Hensynet til barnets beste i Grunnloven og barnevernloven}

Gjennom grunnlovsrevisjonen i 2014 ble en rekke av de sentrale menneskerettighetsbestemmelsene, herunder bestemmelsene om barnets beste, tatt inn i selve Grunnloven. Grunnloven paragraf 104 andre ledd lyder: 
«Ved handlinger og avgjørelser som berører barn, skal barnets beste være et grunnleggende hensyn.»

Grunnloven paragraf 104 andre ledd er utformet etter mønster av barnekonvensjonen artikkel 3. Dette tilsier at det derfor, ved tolkningen av Grunnloven, må trekkes veksler på internasjonal tolkningspraksis, herunder uttalelser fra både barnekomiteen og EMD (jf. Dok. 16 (2011-2012); Rt-2015-93 avsnitt 64). I utlendingssaker har altså Høyesterett gradvis tillagt barnets beste en økt vekt i avveiningen mot hensynet til en effektiv og rettferdig utlendingsforvaltning. I barnevernet innebærer dette at «Grunnloven $\$ 104$, andre ledd krever at barnets beste er det avgjørende hensyn i barnevernssaker, med mindre barnet i helt ubetydelig grad er berørt» (Sørensen, 2016, s. 319-320). Bakgrunnen for at man ønsket å ha denne bestemmelsen som en del av Norges Grunnlov, kan ses som et uttrykk for den grunnverdien man mener barn har i samfunnet vårt. Som kontroll- og konstitusjonskomiteen uttrykte det som en del av forarbeidene til grunnlovsendringen, er ikke barn bare «sårbare og har særlig behov for vern for å kunne leve frie, trygge og verdige liv; de er også i en spesiell avhengighetsstilling, og det i en særlig formativ fase av det liv de skal bruke til å utøve de friheter og rettigheter som tilkommer alle» (Innst. $186 \mathrm{~S}$ (2013-2014)).

I dagens barnevernlov paragraf 4-1 finner vi prinsippet om barnets beste formulert slik:

Ved anvendelse av bestemmelsene i dette kapitlet skal det legges avgjørende vekt på å finne tiltak som er til beste for barnet. Herunder skal det legges vekt på å gi barnet stabil og god voksenkontakt og kontinuitet i omsorgen.

Det skal altså legges avgjørende vekt på hva som er til barnets beste. Hensynet til barnets beste i barnevernssaker tillegges med dette en tydeligere vekt enn det som følger av barnekonvensjonen. Høyesterett anvender begrepet «overordnet betydning» i storkammersakene, og EMD bruker det tilsvarende begrepet "paramount importance». Høyesterett konstaterer nå at konvensjonspraksis ikke gir behov for å endre norsk barnevernlovgivning (HR-2020-661-S avsnitt 109). Det taler for at Høyesterett ikke har ment å endre at hensynet til barnets beste i barnevernet skal ha avgjørende vekt, slik det uttrykkelig står i barnevernloven. 
Hensynet til barnets beste gjelder heller ikke bare når man skal «finne tiltak», men omfatter alle avgjørelser eller handlinger rettet mot barnet i barnevernet, for eksempel i undersøkelsen og i gjennomføring av tiltak, som frivillige hjelpetiltak og ved plassering i fosterhjem og institusjon. «Barnets beste» er altså den skjønnsmessige vurderingen som gjøres når det er slått fast at lovens øvrige vilkår er oppfylt. Denne vurderingen beror da på en konkret vurdering av mange ulike momenter, der stabil og god voksenkontakt og kontinuitet i omsorgen er sentralt.

I Prop. 106L (2012-2013) har Barne-, likestillings- og inkluderingsdepartementet oppsummert hvilke momenter man mener faller innunder denne skjønnsmessige vurderingen av barnets beste (s. 82-83). Her løftes frem særlig fire momenter: tilknytnings- og relasjonskvalitet, biologiske bånd, mildeste effektive inngrep og barnets medvirkning. På denne måten konkluderer departementet med at tilknytningskvalitet er et viktig moment $\mathrm{i}$ «barnets beste»-vurderingen, men at det ikke er behov for å gjøre dette til et eget prinsipp, slik som Raundalenutvalget foreslo i NOU 2012: 5. Ekspertutvalgets mandat var som tidligere nevnt å utrede det biologiske prinsipp i barnevernet, og de konkluderte med at beskyttelse av barns utvikling måtte ha tydelig forrang i forhold til det biologiske prinsippet. Departementet mente derimot at tilknytningskvalitet ikke skulle ha forrang fremfor andre viktige momenter.

Dette var i tråd med høringsuttalelser, der særlig flere jurister var kritiske til å gjøre tilknytningskvalitet til et eget prinsipp. Man mente dette ville smalne inn det komplekse prinsippet om barnets beste. Tilknytningsmomentet måtte for eksempel vurderes annerledes om saken omhandlet små barn, i motsetning til der det dreide seg om eldre barn. Tilknytning har også ulik betydning i ulike kulturer, og det kan derfor være utfordrende å måle. I høringsuttalelsen ble det lagt vekt på at psykologiske teorier, som alle andre vitenskapelig forankrede teorier, endrer seg over tid, og at det overordnede prinsippet om barnets beste derfor måtte favne videre. I kritikken understreket man at sterkere fokus på tilknytningskvalitet kunne gi sakkyndige økt makt i prosessen og dermed medføre en svekkelse av partenes rettssikkerhet. Når de sakkyndige med faglig tyngde konkluderer med hva som er til barnets beste i den konkrete saken, kan det være utfordrende for foreldrene og barnet selv å få frem andre aspekter 
ved barnets liv. Det har dessuten blitt etterlyst gode kliniske metoder for å måle tilknytningskvalitet, og hvem som i så fall er tilstrekkelig kompetente i barnevernet til å utføre slike målinger. Disse momentene er også vektlagt av barnevernlovutvalget (NOU 2016: 16 s. 52-53).

Barnets beste er altså en grunnleggende norm i menneskerettighetene og et internasjonalt anerkjent rettsprinsipp. Prinsippet om barnets beste i barnevernloven må derfor ses i sammenheng med de menneskerettigheter et barn har:

1) Alle barn har rett til omsorg og beskyttelse.

2) Alle barn har rett til familieliv.

3) I avveiningen mellom rett til omsorg og beskyttelse og rett til familieliv skal barnets beste etter barnevernloven være det avgjørende hensynet.

4) I denne vurderingen av hva som er til barnets beste, har barnet rett til å medvirke.

\section{Rett til omsorg og beskyttelse}

Alle barn har en grunnleggende rett til omsorg og beskyttelse. Dette er en rett barnet har, uansett hvem som har omsorgen og foreldreansvaret. Denne retten følger direkte av barnekonvensjonen artikkel 3 nr. 2 og av Grunnloven paragraf 104 tredje ledd. Staten har etter barnekonvensjonen artikkel 19 dessuten en plikt til å beskytte barn mot omsorgssvikt. Også den norske barnevernloven understreker allerede i formålsparagrafen nødvendigheten av å sikre barn omsorg og beskyttelse. Den store betydning dette har i barnevernet, viser seg på en åpenbar måte i tittelen på barnevernlovutvalgets forslag til ny barnevernlov, som kom i 2016: «Sikring av barnets rett til omsorg og beskyttelse» (NOU 2016: 16).

Det vanlige er at denne retten ivaretas av foreldrene gjennom barnets oppvekst. Etter lov om barn og foreldre (barnelova [bl.], 1981) paragraf 30 er omsorg og beskyttelse av barnet en sentral del av foreldreansvaret. Dette er ikke kun en plikt; foreldre har en selvstendig rett til å utøve foreldreansvaret, og staten har også en plikt til å tilrettelegge for at barn kan vokse opp hos sine foreldre. Som Lucy Smith påpekte for 40 år siden om foreldrenes rett til sine barn, og som fortsatt er en gjeldende rettslig forståelse: «Det er en rett, hevdes det, som har sitt utspring $i$ et grunnleggende faktum i de 
vestlige land, nemlig at barna ikke tilhører staten og at staten derfor setter og må sette sine rettigheter i forhold til barna etter foreldrene» (Smith, 1980, s. 331). I dag ville vi kanskje også understreke at barna verken tilhører staten eller foreldrene, men at de på et selvsagt vis tilhører seg selv.

\section{Rett til familieliv}

Både barn og foreldre har altså en rett til familieliv og til å leve sammen, og staten kan ikke gjøre vilkårlige og uforholdsmessige inngrep i familien, jamfør barnekonvensjonen artikkel 16 og 7, EMK artikkel 8 og Grunnloven paragraf 102. Denne retten til familieliv opphører ikke selv om det offentlige overtar omsorgen. Dette ser vi uttrykt i barnekonvensjonen artikkel 9 og i samværsreglene i barnevernloven. Omsorgsovertakelse er i utgangspunktet et midlertidig tiltak, og barneverntjenesten skal legge til rette for at barnet kan flytte tilbake til foreldrene hvis dette er til barnets beste, jamfør barnevernloven paragraf 4-16 og 4-21. Gjenforeningsmålet etter en omsorgsovertakelse synes også å ha fått et økt fokus i de siste EMD-dommene og høyesterettsavgjørelsene. Retten til familieliv bygger på det verdisynet at det er foreldrene som har ansvaret for og også en plikt til å gi omsorg for sine barn, og at barnevernet kun har et subsidiært ansvar, der denne omsorgen ikke ivaretar barnets grunnleggende rettigheter, jamfør barnekonvensjonen artikkel 19.

Retten til familieliv står ikke direkte nedfelt i barnevernloven, men følger av det biologiske prinsipp som loven er forankret i. Her kunne man tenkt seg muligheten for å lovfeste dette prinsippet i barnevernloven, som antydet hos for eksempel Stang og Baugerud (2018, s. 147). I departementets forslag til ny barnevernlov har man derimot valgt bevisst at retten til familieliv ikke skal fremkomme direkte i loven. Departementet mener en slik lovfesting av det biologiske prinsippet «kan skape uklarheter i praksis som vil være uheldig» (Barne- og likestillingsdepartementet, 2019, s. 45), og da særlig med tanke på at barnevernlovens formål er å beskytte de utsatte barna. Som førstevoterende uttaler i HR-2020-661-S i avsnitt 85: «I norske avgjørelser ligger hensynet til familiebånd en del ganger mer som en underforstått og delvis ikke uttalt forutsetning, men hensynet til barnets beste trer tydeligst frem, selv om Høyesterett i sine avgjørelser som nevnt har understreket betydningen av de familiemessige bånd.» 
Hensynet til barnets beste er altså en selvstendig rettighet samtidig som prinsippet regulerer den avveiningen barnevernet må gjøre mellom barnets rett på omsorg og beskyttelse og retten til familieliv. Det innebærer at barnevernet ofte vurderer det slik at frivillige hjelpetiltak som støtter foreldrene, er til barnets beste, slik at barnet får mulighet til både å få hjelp og samtidig få vokse opp med sin familie. I noen tilfeller vil barnets rett til omsorg og beskyttelse bety at barnevernet vurderer det som barnets beste å flytte barnet til en annen omsorgsbase for kortere eller lengre tid. Uten denne myndigheten til å gripe inn i den private sfæren mot foreldrenes vilje vil ikke samfunnet være i stand til å beskytte de mest utsatte barna. Vi har i dag omfattende dokumentasjon på at mange barn lever i uholdbare livssituasjoner og med alvorlig omsorgssvikt uten å bli sett, og vi har kunnskap om hvor skadelig og potensielt livsfarlig dette kan være for barnet (NOU 2017: 12).

\section{Rett til medvirkning}

Når barnevernet vurderer om avgjørelsen vil være til barnets beste, kan denne vurderingen ikke løsrives fra barnets rett til å medvirke i sin egen sak. At barnets mening er en helt sentral del av «barnets beste»-prinsippet, ble omtalt allerede i forarbeider til barnevernloven av 1992 (Ot.prp. nr. 44 1991-1992, s. 28; Innst. O. nr. 80 1991-92, s. 13). Ulike tilsyn og forskningsrapporter viser at barnevernet fortsatt kan ha til dels store utfordringer knyttet til barnets medvirkning (Lurie et al., 2015, s. 19; Helsetilsynet, 2019, s. 117).

Barnets rett til medvirkning er en grunnleggende menneskerettighet. Det står ikke eksplisitt i Den europeiske menneskerettskonvensjonen (EMK) at barn skal høres, men dette anses likevel å være en av de menneskerettslige prosessuelle garantier som også omfatter barn i barnevernet. I EMK artikkel 8 om rett til familieliv og privatliv er det oppstilt prosessuelle krav som er fulgt og utviklet i praksis ved EMD, og som også gjelder barnevernssaker (Sørensen, 2016, s. 342-343). Medvirkning er for alle mennesker en viktig forutsetning for å ivareta sine rettigheter.

Tradisjonelt har det vært løftet frem to aspekter ved beskyttelse av barns rettigheter. Det ene tar utgangspunkt i barnets sårbarhet, det andre i barns evne til å opptre selv (Sandberg, 2020a, s. 98). Barnekonvensjonen 
artikkel 12 gir alle barn rett til å gi uttrykk for sin mening fra de er i stand til å danne seg egne synspunkter, og disse synspunktene skal tillegges behørig vekt i samsvar med alder og modenhet. FNs barnekomité understreker at barnets rett til å bli hørt er en av de grunnleggende verdiene i barnekonvensjonen (FNs barnekomité, 2009, generell kommentar nr. 12 avsnitt 2). Dette innebærer at barnekonvensjonens artikkel 12 ikke bare er en rettighet i seg selv, men at barns rett til å bli hørt er noe som skal tas hensyn til, også ved fortolkning og gjennomføring av andre rettigheter. Barn i Norge har dessuten fått en grunnlovfestet rett til å bli hørt i spørsmål som gjelder dem selv, jamfør Grunnloven paragraf 104 første ledd.

På barnevernfeltet er denne retten nedfelt i barnevernloven i flere bestemmelser. Etter paragraf 6-3 skal barn som er fylt sju år, eller yngre barn som er i stand til å danne seg egne synspunkter, bli informert og gis anledning til å uttale seg før avgjørelser tas. Her gir våre nasjonale regler barnet en ubetinget rett til å få uttale seg ved fylte sju år, uavhengig av utviklingsnivå eller modenhet. Barnekonvensjonen artikkel 12, derimot, knytter medvirkning til at barnet er i stand til å danne seg egne synspunkter.

I 2018 fikk vi en ny generell regel i barnevernloven paragraf 1-6 om barnets rett til medvirkning i alle forhold som vedrører barnet etter barnevernloven. Her ble retten til tilstrekkelig og tilpasset informasjon understreket, samt at barnets stemme skal lyttes til og vektlegges i samsvar med alder og modenhet. I høringsforslaget til ny barnevernlov ønsker man å fjerne aldersgrensen på sju år for barns rett til å uttale seg (Barne- og likestillingsdepartementet, 2019, s. 46). Dette er i tråd med NOU 2016: 16 og FNs barnekomité (2009) i generell kommentar nummer 12, der det frarådes å bruke aldersgrenser. Dette bygger på at slike vurderinger alltid må være konkrete og knyttes til barnets alder og utvikling. Også Familie- og kulturkomiteen på Stortinget har i behandlingen av Prop. 169 L (2016-2017) oppfordret regjeringen til å fjerne aldershenvisningen i loven. Hvis saken kommer for fylkesnemnda, kan det i dag oppnevnes en egen talsperson for barnet etter barnevernloven paragraf 7-9. I departementets siste lovforslag har man i tillegg foreslått å gi barn anledning til å uttale seg direkte til fylkesnemnda (Barne- og likestillingsdepartementet, 2019, s. 278).

Denne økte oppmerksomheten i barnevernlovgivningen på å styrke barnets rett til medvirkning har blant annet sin årsak i den kunnskapen 
vi etter hvert har fått om store mangler i hvordan barnevernet håndterer denne rettigheten. Dette er særlig knyttet til at mange barneverntjenester viser seg å ha svake rutiner på å samtale med barn, og at det her ser ut til å være store variasjoner mellom kommunene (Helsetilsynet, 2012). Nyere funn bekrefter mye av det samme (Helsetilsynet, 2019). I denne siste publikasjonen fra Helsetilsynet vises det til at barneverntjenestene som oftest snakker med barna gjennom hele saksgangen, men informasjon som barnet gir i saken, viser seg i mange tilfeller likevel å glippe underveis i saksdokumentene, eller den tillegges liten vekt når avgjørelsen begrunnes. Det er altså mye som tyder på at barns rettssikkerhetssituasjon på dette området fortsatt er utfordrende.

\section{Minste inngreps prinsipp}

«Barnets beste»-vurderingen skal dessuten være tuftet på minste inngreps prinsipp, som også er et grunnleggende hensyn i barnevernet. Dette går ut på at tiltakene i barnevernet ikke må være mer omfattende enn nødvendig, og de skal gjennomføres så skånsomt som mulig. En slik rett omfatter både foreldre og barn, og den bygger på det menneskerettslige og forvaltningsrettslige prinsipp om at alle inngrep fra det offentlige skal være forholdsmessige. Det må være proporsjonalitet mellom de målene staten setter, og de midlene som brukes for å nå disse målene. Dette prinsippet er særlig viktig i barnevernssaker, der tiltak kan gripe dypt inn i de menneskerettighetene både barn og voksne har. I kraft av den store makten som ligger i barnevernets mandat, vil beslutninger i barnevernet raskt oppleves som særlig tyngende og inngripende. Jo mer inngripende tiltaket er for familielivet, desto tydeligere må barnevernet begrunne og dokumentere hvilken betydning og vekt man har lagt på hensynet til barnets beste i avveiningen mot barnets behov for omsorg og beskyttelse.

\section{Om barnets beste som materiell vurderingsnorm og prosessuell norm}

Både barnevernlovutvalget og departementet i sitt høringsforslag har valgt å utforme en bestemmelse om barnets beste som er nært knyttet til 
barnekonvensjonen, og det løftes her frem to dimensjoner ved «barnets beste»-prinsippet (Sørensen, 2016, s. 315, NOU 2016: 16, s. 54-55; Barne- og likestillingsdepartementet, 2019, s. 34).

Prinsippet om barnets beste i barnevernet er for det første en materiell vurderingsnorm som indikerer hva dette prinsippet faktisk inneholder av rettigheter for barnet og plikter for det offentlige. Som en materiell regel er barnets beste både en optimaliseringsnorm og en avveiningsnorm. Som optimaliseringsnorm innebærer dette at man foretar en konkret og helhetlig vurdering av mulige konsekvenser for barnet, for å finne ut hva som alt i alt er til barnets beste. Her må barnevernet ta hensyn til de sentrale «barnets beste»-momentene som løftes frem av FNs barnekomitée, og som omhandler barnets synspunkter, barnets identitet (som kjønn, seksuell legning, nasjonal opprinnelse, religion og livssyn, kulturell identitet og personlighet), bevaring av familiemiljø og opprettholdelse av relasjoner, omsorg, beskyttelse og sikkerhet for barnet, barnets særlige sårbarhet, barnets rett til helse og retten til utdanning (FNs barnekomité, generell kommentar nr. 14 avsnitt 52-79).

Denne listen fra barnekomiteen er ikke uttømmende, men angir momenter som er relevante $\mathrm{i}$ «barnets beste»-vurderingen. Selv om barnevernloven paragraf 4-1 ikke angir ytterligere momenter enn «stabil og god voksenkontakt og kontinuitet i omsorgen», gir barnekomiteens momentliste føringer for barnevernets vurderinger av barnets beste. Andre land som Finland, Australia og England har i sin lovgivning valgt å gi klarere instruksjoner på hvilke forhold som skal vurderes i en «barnets beste»-vurdering, og som også ligger nærmere barnekonvensjonens formuleringer (Læret \& Skivenes, 2016, s. 36).

Her må barnevernet helt konkret avveie disse ulike momentene mot hverandre med utgangspunkt i akkurat dette barnets liv. Som avveiningsnorm ser vi også at barnets beste alltid må avveies mot andre hensyn, for eksempel hensyn til søsken og til foreldrenes selvstendige rett til å delta i barnets oppvekst. Alle relevante momenter skal tydeliggjøres i vurderingen, men det avgjørende hensyn er hva som alt $i$ alt er til barnets beste.

Barnevernlovutvalget foreslo en «barnets beste»-bestemmelse som lå tett til barnekomiteens momentliste (NOU 2016: 16, s. 54). I høringsforslaget til ny barnevernlov har Barne- og likestillingsdepartementet i 
paragraf 1-3 valgt en formulering om barnets beste som fortsatt er av mer overordnet karakter. Man lovfester ingen momentliste over innholdet av barnets beste, og man foreslår også at hensynet til stabil og god voksenkontakt og kontinuitet i omsorgen tas ut av lovteksten. Departementet har likevel bygget forslaget på kjerneverdien i «barnets beste»-begrepet i barnekonvensjonen, og også på momenter som er fremhevet av FNs barnekomité og av barnevernlovutvalget (Barne- og likestillingsdepartementet, 2019, s. 42).

Lovforslaget paragraf 1-3 lyder:

Barnets beste er et grunnleggende hensyn i alle handlinger og avgjørelser som berører et barn. Hensynet til barnets beste skal være avgjørende når det vurderes om barneverntiltak skal iverksettes, og hvilke tiltak som skal velges. Hva som er til barnets beste, må avgjøres etter en konkret vurdering av det enkelte barns behov.

I tillegg til å være en materiell vurderingsnorm er prinsippet om barnets beste også en prosessuell norm og en saksbehandlingsregel, og dette setter krav til beslutningsprosessen. Her må barnevernet foreta en forsvarlig utredning av aktuelle konsekvenser som avgjørelsen kan få for barnet. Dette setter også krav til begrunnelsen for den beslutningen barnevernet treffer. I dagens barnevernlov har vi derfor fått regler om at det i vedtaket skal fremgå hvordan barnets beste er vurdert, herunder betydningen av barnets mening, jamfør paragraf 6-3 bokstav a. Gjennom ulike tilsyn og forskning og de siste avgjørelsene ved Den europeiske menneskerettsdomstol (EMD) og i Høyesterett ser vi at norsk barnevern har et klart potensial for å utforme kvalitativt bedre begrunnelser i sine saker.

\section{Oppsummering}

Når barnevernet på vegne av samfunnet utfører handlinger rettet mot en familie, settes ulike verdier i spill, og barnevernsarbeideren må også alltid spørre seg om disse vurderingene er juridisk og etisk holdbare (Nordby, Bennin \& Buer, 2013, s. 20). Det er vel få - om noen - som må gjøre så krevende faglige vurderinger som barnevernet, og dette setter store krav 
til å være åpen og tydelig på hvilke argumenter man mener er gyldige, og hvordan disse er avveid mot hverandre. Dette kan gi andre innsyn i hvordan hensynet til barnets beste er ivaretatt, og det vil dermed bedre kunne ivareta familien og barnets krav på rettssikkerhet.

I dette kapitlet har jeg hatt et juridisk perspektiv med søkelys på hvilke rettsregler vi har om hensynet til barnets beste, og hvordan dette aktivt kan brukes som argumenter i en barnevernssak. Hovedvekten i fremstillingen er knyttet til barnevernloven og begrunnelser og beslutninger i barnevernet, men målet har også vært å se de nasjonale reglene i sammenheng med menneskerettighetene. Dette gjelder særlig barnets beste som en grunnverdi i barnekonvensjonen. For å forstå et rettsområde kan det også være nødvendig å ha innsikt i hvilken utvikling som har vært på dette feltet. Uten å behandle hele historikken har jeg blant annet vist til relevante diskusjoner om å gjøre tilknytningskvalitet til et eget prinsipp, og til utviklingen av barnets selvstendige rett til barneverntjenester og rett til å medvirke.

Hva er så innholdet av barnets beste? Barne- og likestillingsdepartementet har oppsummert noen viktige momenter: tilknytnings- og relasjonskvalitet, biologiske bånd, mildeste effektive inngrep og barnets medvirkning (Prop.106 L 2012-2013). Disse momentene må også ses i sammenheng med de grunnleggende menneskerettigheter alle barn har. Her har FNs barnekomité utarbeidet en liste over noen sentrale momenter for en «barnets beste»-vurdering: rett til omsorg og beskyttelse, rett til familieliv, rett til å medvirke, rett til å bevare sin identitet, rett for barn i særlig sårbare situasjoner, rett til helse og rett til utdanning (Generell kommentar nr. 14, avsnitt 52-79; Haugli, 2020, s. 61-64; Barne- og likestillingsdepartementet, 2019, s. 34). Her må barnevernet foreta en konkret avveining av de relevante momentene med det målet at avgjørelsen ivaretar barnets interesser og grunnleggende rettigheter. I denne vurderingen må barnevernet også trekke inn de føringer som følger av avgjørelser fra Den europeiske menneskerettsdomstolen og fra Høyesterett. Vi er inne i en tid der ulike verdisyn på hva som er til barnets beste, mer tydelig kommer til overflaten. De siste rettsavgjørelsene illustrerer tydelig hvilke samfunnsmessige spenninger som er knyttet til hvordan man skal vekte den grunnleggende verdien om rett til familieliv opp mot barnets krav til omsorg og beskyttelse. 


\section{Kilder}

\section{Lover}

Lov 17. mai 1814 Kongeriket Norges Grunnlov

Lov 8. april $1981 \mathrm{nr} .7$ om barn og foreldre (barnelova)

Lov 17. juli $1992 \mathrm{nr} .100$ om barneverntjenester (barnevernloven)

Lov 21. mai $1999 \mathrm{nr}$. 30 om styrking av menneskerettighetenes stilling i norsk rett (menneskerettsloven)

\section{Internasjonale konvensjoner}

Konvensjon 4. november 1950 om beskyttelse av menneskerettighetene og de grunnleggende friheter (EMK)

FNs konvensjon 20. november 1989 om barnets rettigheter (Barnekonvensjonen)

FNs barnekomité, Generell kommentar nr. 12 (2009) om barnets rett til å bli hørt.

FNs barnekomité, Generell kommentar nr. 13 (2011) om barnets rett til frihet fra alle former for vold.

FNs barnekomité, Generell kommentar nr. 14 (2013) om barnets rett til at hans eller hennes beste skal være et grunnleggende hensyn.

\section{Forarbeider og andre offentlige dokumenter}

Barne- og likestillingsdepartementet. Høringsforslag - forslag til ny barnevernslov av 4. april 2019. Hentet fra: https://www.regjeringen.no/no/dokumenter/ horing---forslag-til-nybarnevernslov/id2639982/

Dok. 16 (2011-2012). Rapport til Stortingets presidentskap fra Menneskerettighetsutvalget om menneskerettigheter i Grunnloven.

Helsetilsynet. (2012). Oppsummering av landsomfattende tilsyn i 2011 med kommunalt barnevern - undersøkelse og evaluering, rapport 2/2012. Hentet fra: https://www. helsetilsynet.no/publikasjoner/rapport-fra-helsetilsynet/2012/oppsummering-avlandsomfattende-tilsyn-i-2011-med-kommunalt-barnevern/

Helsetilsynet. (2019). Det å reise vasker øynene. Gjennomgang av 106 barnevernssaker (Rapport 17.01.2019). Hentet fra https://www.helsetilsynet.no/globalassets/ opplastinger/publikasjoner/rapporter2019/helsetilsynet_rapport_unummerert_ gjennomgang_106_barnevernsaker.pdf

Innst. O. nr. 8o (1991-1992). Innstilling fra forbruker- og administrasjonskomiteen om lov om barneverntjenester (barnevernloven).

Innst. 186 S (2013-2014). Innstilling fra Stortingets kontroll- og konstitusjonskomite om grunnlovsforslag om grunnlovfesting av sivile og politiske menneskerettigheter, med unntak av romertall X og XXIV. 
NOU 2012: 5 Bedre beskyttelse av barns utvikling. Ekspertutvalgets utredning om det biologiske prinsipp i barnevernet.

NOU 2016: 16 Ny barnevernslov. Sikring av barnets rett til omsorg og beskyttelse.

NOU 2017: 8 Særdomstoler på nye områder? Vurdering av nye domstolsordninger for foreldretvister, barnevernsaker og utlendingssaker.

NOU 2017: 12 Svikt og svik. Gjennomgang av saker hvor barn har vært utsatt for vold, seksuelle overgrep og omsorgssvikt.

Ot.prp. nr 44 (1991-1992). Om lov om barneverntjenester (barnevernloven).

Prop. 106 L (2012-2013). Endringer i barnevernloven.

Prop. 169 L (2016-2017). Endringer i barnevernloven mv. (bedre rettssikkerhet for barn og foreldre).

\section{Avgjørelser fra Høyesterett}

Rt-2012-1985

Rt-2015-93

Rt-2015-110

HR-2020-661-S

HR-2020-662-S

HR-2020-663-S

\section{Avgjørelser fra EMD}

Case of Strand Lobben and others v. Norway (a), dom av 30. november 2017, klagenummer 37283/13

Case of Strand Lobben and others v. Norway (b), dom i Storkammeret 10. september 2019.

\section{Litteratur}

Bernt, J. F. \& Rasmussen, Ø. (2010). Frihagens forvaltningsrett. Bind 1. Bergen: Fagbokforlaget.

Haugli, T. (2020). Hensynet til barnets beste. I N. Høstmælingen, E. S. Kjørholt \& K. Sandberg (Red.): Barnekonvensjonen. Barns rettigheter i Norge (4. utg., s. 55-78). Oslo: Universitetsforlaget.

Høstmælingen, N. (2012). Internasjonale menneskerettigheter (2. utg.). Oslo:

Universitetsforlaget.

Lindboe, K. (2012). Barnevernrett. Oslo: Universitetsforlaget. 
Lurie, J., Kvaran, I., Tjelflaat, T. \& Sørlie, H. E. (2015). Barneverntjenestens arbeid med barneverntjenestens arbeid med barnevernsundersøkelser i Midt-Norge (Rapport 4/2015). Trondheim: NTNU, Regionalt kunnskapssenter for barn og unge - psykisk helse og barnevern.

Læret, O. K. \& Skivenes, M. (2016). Kvalitet og legitimitet i barnevernets beslutninger. I Ø. Christiansen, B. H. Kojan (red.), Beslutninger i barnevernet (s. 178-194). Oslo: Universitetsforlaget.

Nordby, H., Bennin, C. \& Buer, B. A. (2013). Etikk i barnevern. Oslo: Gyldendal Akademisk.

Ofstad, K. \& Skar, R. (2015) Barnevernloven med kommentarer (6. utg.). Oslo: Gyldendal.

Sandberg, K. (2020a). Barns rett til å bli hørt. I N. Høstmælingen, E. S. Kjørholt \& K. Sandberg (Red.), Barnekonvensjonen. Barns rettigheter i Norge. Oslo: Universitetsforlaget.

Sandberg, K. (2020b). Kommentar til Høyesteretts storkammeravgjørelser om barnevern etter EMDs dommer mot Norge. Juridika.no. Hentet 27. april 2020 fra https://juridika.no/innsikt/Kommentar-til-H\%C3\%B8yesterettsstorkammeravgj\% $\mathrm{C}_{3} \%$ B8relser-om-barnevern-etter-EMDs-dommer-mot-Norge

Smith, L. (1980). Foreldremyndighet og barnerett. Oslo: Universitetsforlaget.

Stang, E. G. (2007). Det er barnets sak. Barnets rettsstilling i sak om hjelpetiltak etter barnevernloven $\$ 4-4$. Oslo: Universitetsforlaget.

Stang, E. G. (2020). Barns rett til familie og omsorg, særlig om barnevernet. I N. Høstmælingen, E. S. Kjørholt \& K. Sandberg (Red.), Barnekonvensjonen. Barns rettigheter $i$ Norge. Oslo: Universitetsforlaget.

Stang, E. G. \& Baugerud, G. (2018). Samvœr etter omsorgsovertakelse. En barnevernfaglig og juridisk utredning. (OsloMet Rapport 2018 nr. 10). Hentet fra https://skriftserien.hioa.no/index.php/skriftserien/article/view/612/133

Sørensen, C. B. (2016). Barnevern og menneskerettighetene. Utredning til barnevernslovutvalget. I NOU 2016: 16 Ny barnevernslov. Sikring av barnets rett til omsorg og beskyttelse. Oslo: Norges offentlige utredninger. 


\title{
KAPITTEL 3
}

\section{$\AA$ A balansere mellom barnevernets prinsipper}

\section{Grethe Netland}

\author{
Førsteamanuensis, Høgskolen i Innlandet
}

\begin{abstract}
The focus of this chapter is the potential conflicts between the values that are basic in the work of Norwegian child protection service. Such values are expressed in principles that serve as guidelines for judgement and decisions in the field. 'The best interest of the child' principle is held to be grounding. The 'mildest intervention' principle and the 'biological' principle are normally held to be at the core of how the best interest of the child is to be understood. Important in child protection work, is to interpret the principles, weigh them, and consider what implications they should have in specific cases. I argue that if, for some reason, one principle is ascribed too much weigh on the cost of others, the solution for the child might not be in its best interest. I highlight the importance of not only weighing the principles against each other, but also creating a coherent balance between the principles, people's moral intuitions and the actual practices of the service. To this end, I suggest that John Rawls's model called reflective equilibrium might be workable.
\end{abstract}

Keywords: child protection service, John Rawls, principles, reflective equilibrium

\section{Introduksjon}

Et prinsipp kan vi forstå som en grunnleggende norm som gir retning for resonnement og handling. Norsk barnevern opererer med tre slike grunnleggende normer. Prinsippet om barnets beste - at handlingsvalg og beslutninger skal ha barnet beste for øye - regnes gjerne som

Sitering av denne artikkelen: Netland, G. (2020). Å balansere mellom barnevernets prinsipper. I H. Nordby \& A. Halsa (Red.), Verdier i barnevern (Kap. 3, s. 49-65). Oslo: Cappelen Damm Akademisk. https://doi.org/10.23865/noasp.103.ch3

Lisens: CC BY-ND 4.0 
førsteprinsipp i den forstand at det er helt grunnleggende. ${ }^{1}$ De to andre prinsippene er også grunnleggende, men de er på sett og vis utledet av førsteprinsippet om barnet beste - de utsier noe om hva som er til det beste for barnet. Det mildeste inngreps prinsipp - at tiltak i regi av barnevernet skal være minst mulig inngripende for barnet og familien - sier at det er best for barnet og familien at tiltaket ikke er mer inngripende enn absolutt nødvendig. ${ }^{2}$ Det mildeste inngreps prinsipp er altså en spesifikasjon av hva som er det beste for barnet og for andre involverte parter. Det biologiske prinsipp - at en sak om mulig skal løses i biologisk familie (eller adoptivfamilie) - sier at tilknytning til biologiske foreldre i seg selv er et gode og til det beste for barnet. ${ }^{3}$ Det biologiske prinsipp er slik sett også en spesifikasjon av prinsippet om barnet beste.

Prinsippene, slik de står, er tydelige nok og er hver for seg rimelige og fornuftige. De er i tråd med en allmennmoralsk oppfatning som anerkjenner at familiebånd har verdi, og som anerkjenner at barn og familier i vanskelige situasjoner er sårbare og ikke skal utsettes for illegitim inngripen fra statsmakten. Men det ligger et betydelig konfliktpotensial i fortolkningen av prinsippene. I en konkret sak kan barnevernet, barnet og foreldrene ha helt ulike oppfatninger av hva som er best for barnet. Bak disse ulike oppfatningene ligger ulike verdier, det vil si ulike oppfatninger av hva som er viktigst, eller hvilke interesser som bør veie tyngst. Barnevernets arbeid befinner seg i en verdikonfliktsone der ulike hensyn må veies mot hverandre, og der en handling, en beslutning, et vedtak ikke alltid ivaretar involverte parters verdier på en og samme tid.

Denne artikkelen skal handle om fortolkning av de grunnleggende prinsippene. Ideelt sett skal prinsippene fungere som retningsgivende i en helhetlig «alle forhold tatt i betraktning»-tilnærming til saker. Men vi kan observere at prinsippene, eller bestemte fortolkninger av dem, i enkeltsaker eller i visse tidsepoker ser ut til å bli tillagt så stor vekt at det utvikles en praksis der helheten mistes av syne. Konsekvensene kan bli

$1 \quad$ Prinsippet om barnets beste, se for eksempel barnevernloven $\$ 4-1$ og UNCHR Guidelines on Determining the Best Interests of the Child.

2 Reflekteres i barnevernloven $\$ \$ 4-4,4-12$ og 4-21.

3 Reflekteres flere steder i barnevernloven, blant annet i de samme bestemmelsene som reflekterer det mildeste inngreps prinsipp: $\$ \$ 4-4,4-12$ og 4-21. 
uheldige for det enkelte barn og den enkelte familie, og praksisene kan komme i konflikt med allmennmoralske rettferdighetsoppfatninger - det vi med andre ord kan kalle våre moralske intuisjoner.

Filosofen John Rawls (1921-2002) har foreslått en modell for hvordan våre samfunnsinstitusjoner kan forholde seg når prinsipper, praksiser og rettferdighetsvurderinger kommer i utakt. Modellen kalles på norsk reflektert likevekt ${ }^{4}$, hvor ideen er at prinsippene, praksisene eller rettferdighetsvurderingene må revurderes når disse faktorene viser seg å være innbyrdes inkonsistente.

I det følgende skal jeg først redegjøre for ideen om reflektert likevekt. Dernest skal jeg si litt mer om prinsippene barnevernet arbeider etter, før jeg skisserer en tenkt case som illustrerer dårlig samsvar mellom barnevernets prinsipper, praksiser og rettferdighetsvurderinger, og hvordan ideen om reflektert likevekt kan brukes for å oppnå bedre balanse.

\section{Ideen om reflektert likevekt mellom prinsipper, praksiser og rettferdighetsoppfatninger}

Rawls regnes som en av de mest innflytelsesrike filosofene i nyere tid. Han er særlig kjent for boken A Theory of Justice (1971/1999), som er et bidrag til debatten om hvilke grunnleggende prinsipper som bør legges til grunn for rettferdig fordeling av materielle og immaterielle goder i et demokratisk samfunn. Det er våre samfunnsinstitusjoner som står for denne fordelingen, slik at Rawls' teori om rettferdighet er ment for de beslutninger, med tilhørende begrunnelser, som fattes i disse institusjonene: domstolene, nasjonalforsamling og regjering med dens underliggende forvaltningsenheter - barnevernet blant dem.

Rawls' idé om reflektert likevekt inngår som en del av et teoretisk byggverk som hviler på noen grunnleggende antakelser. Jeg skal si litt om dette byggverket for å gi et bilde av hvor ideen om reflektert likevekt har sin plass. Rawls tenker på et samfunn som et system av samarbeid,

4 Reflective equilibirium på originalspråket. På norsk brukes også «reflektiv likevekt» og «refleksiv likevekt». Jeg foretrekker «reflektert» fordi denne termen i større grad assosieres med aktiv handling - likevekten oppnås ved at en aktør har reflektert seg frem til den. 
hvor samarbeid er nødvendig for å at borgerne skal oppnå hva de anser for å være godt. Et slikt samarbeid bør tuftes på noen grunnleggende rettferdighetsprinsipper som borgerne kan enes om. Rawls konstruerer et scenario der borgere kommer sammen for å enes om hvilke prinsipper dette er. Han argumenterer for at prosessen resulterer i følgende to prinsipper (Rawls, 2003, s. 103): ${ }^{5}$

a) Enhver person har det samme ufravikelige krav på et fullstendig tilfredsstillende system av grunnleggende friheter, et system som er forenlig med et slikt frihetssystem for alle.

b) Sosiale og økonomiske ulikheter skal oppfylle to betingelser: For det første skal de knyttes til stillinger og posisjoner som er tilgjengelige for alle, under forhold som sikrer rimelig sjanselikhet, og for det andre skal de være til størst mulig gagn for de dårligst stilte medlemmene av samfunnet (forskjellsprinsippet).

Disse prinsippene handler om følgende:

1) Individenes frihet er begrenset av andres rett til frihet - for eksempel er min rett til fritt å uttrykke meg begrenset av din rett til ikke å bli krenket i det offentlige rom.

2) Ulikheter mellom borgere er legitime bare hvis alle har rimelige muligheter for å oppnå stillinger og posisjoner, og ordninger (lover, regler og retningslinjer) skal være til de svakest stilte sin gunst.

Det siste betyr at når vi skal revurdere en lov, en regel eller en retningslinje, skal endringen være til det bedre for de svakest stilte.

Disse to rettferdighetsprinsippene er altså samfunnsinstitusjonenes førsteprinsipper. Det blir så institusjonenes oppgave å forvalte fellesgodene på en måte som er tro mot disse. De enkelte samfunnsinstitusjonene, inkludert de som skal ivareta barns interesser, skal påse at deres egne prinsipper er i tråd med de to grunnleggende rettferdighetsprinsippene.

5 Som Rawls sier her, er dette en revidert versjon av prinsippene som ble diskutert i A Theory of Justice $\$ \$ 11-14$. 
Prinsippet om barnets beste kan forstås som barnevernets presisering av siste ledd i Rawls' andre rettferdighetsprinsipp: Barnet anses som den svakest stilte i en sak, og vedtak som fattes, skal være barnet til størst gagn.

Rawls har formulert ideen om reflektert likevekt flere steder. Her skal jeg referere til hvordan han redegjør for den i boken Rettferdighet som rimelighet - en reformulering (2003), som er en norsk oversettelse av Justice as Fairness - A reformulation (2001). Når boken har fått undertittelen «en reformulering», er det fordi den er en justering og presisering av $A$ Theory of Justice. Sistnevnte har vært gjenstand for en rik debatt, og reformuleringen er på mange måter et svar på kritiske innlegg i debatten.

Ideen om reflektert likevekt bygger på to grunnleggende antakelser: At samfunnsborgere har rettferdighetssans (en form for moralsk følsomhet) og dessuten evne til å resonnere teoretisk og praktisk. ${ }^{6}$ Vi gjør bruk av disse evnene i alle livets sammenhenger - vi gjør vurderinger om alt fra våre samfunnsinstitusjoner til hverdagslige handlinger og gjøremål. Rettferdighetssansen er forbundet med en intellektuell evne til å trekke slutninger, bruke fantasien og foreta vurderinger - det må vi gjøre for å komme frem til et standpunkt (Rawls, 2003, s. 84).

Veloverveide vurderinger av hva som er rettferdig, er vurderinger vi foretar når vi har anledning til å bruke fornuften og rettferdighetssansen uten at vi står overfor press eller bestemte fristelser. Ofte er våre veloverveide vurderinger forskjellig fra andres, og av og til er våre egne vurderinger i innbyrdes konflikt. Mange av våre alvorligste konflikter, mener Rawls (2003, s. 85), er konflikter i vårt eget indre. Noen ganger er det viktig eller nødvendig å jobbe for at våre vurderinger kommer i bedre samsvar med andres vurderinger, eller at våre egne blir mer konsistente. Det betyr at vi noen ganger må revurdere, utelukke eller trekke tilbake våre veloverveide vurderinger, i alle fall hvis målet er enighet i spørsmål om politisk rettferdighet (Rawls, 2003, s. 86). Med politisk rettferdighet mener Rawls spørsmål om rettferdighet som gjelder for samfunnsinstitusjoner fordeling av goder og prosedyrer for hvordan saker skal behandles.

6 Hva Rawls kaller «det aristoteliske prinsipp» (Rawls, 1999, s. 372-380). 
Sett at du nå observerer at dine egne eller andres veloverveide vurderinger $i$ en sak er inkonsistente med andre vurderinger hos deg selv eller hos andre. For å oppnå reflektert likevekt må vi da finne frem til en oppfatning av politisk rettferdighet som krever færrest mulig endringer i våre opprinnelige vurderinger, men likevel slik at våre generelle overbevisninger, idealer eller hovedprinsipper og spesielle vurderinger stemmer overens.

En vesentlig side ved ideen om reflektert likevekt er at vi må teste ut følgene - eller konsekvensene - av våre idealer og prinsipper før vi kan avgjøre om de er fornuftige og rettferdige (Rawls, 2003, s. 220), og dette må vi gjøre etter hvert som følgene dukker opp. Når vi vurderer hvilke følger et ideal eller et prinsipp får i praksis, kan det vise seg at «følelsene våre og holdningene våre mens vi arbeider med disse følgene, i praksis bringer opp i dagen ting som gjør at idealene må revurderes, men vi kan også komme til å oppdage at følelsene våre hindrer oss i å sette rettferdighetsoppfatningen ut i livet» (Rawls, 2003, s. 220).

Her er det lett å få øye på det dynamiske aspektet ved forholdet mellom prinsipper, praksis og vurderinger. Det dreier seg om å ha en årvåkenhet for inkonsistens mellom dem og å være åpen for endringer i prinsipper, praksiser eller vurderinger for å oppnå større grad av konsistens. Dette betyr at det ikke finnes én bestemt måte å forstå prinsipper på. Prinsippene som gjelder for en samfunnsinstitusjons prosedyrer, beslutninger og begrunnelser for hva som er riktig og rettferdig, må være gjenstand for balansering i en i reflektert likevektprosess. Rawls sier det slik (1993, s. 507, min oversettelse):

[F]ørsteprinsipper [har ikke] spesielle særtrekk som gir dem en spesiell plass i begrunnelsen av en moralsk doktrine. De er sentrale elementer og faktorer ... men begrunnelse hviler på en helhetlig oppfatning og hvordan denne [begrunnelsen] stemmer overens med og organiserer våre veloverveide vurderinger $\mathrm{i}$ reflektert likevekt.... begrunnelse dreier seg om at våre vurderinger bygger opp om hverandre - om at alt passer inn i ett koherent syn.

Oppsummert og satt inn i rammen av en samfunnsinstitusjon som skal beskytte barns interesser: Gjennom tiden er det utviklet prinsipper for hvordan institusjonen «barnevernet» skal beskytte barns interesser, 
jamfør de tre nevnte hovedprinsippene norsk barnevern arbeider etter. Slike prinsipper utrykkes i lov- og regelverk. Om prinsippene, eller mer presist fortolkningen av dem, fører til resultater som er rimelige fornuftige, må vurderes fra sak til sak. Til grunn for en slik vurdering ligger veloverveide rettferdighetsvurderinger hos de som skal forvalte prinsippene.

La oss forestille oss et kommunalt barnevernskontor som gjennom en tid har lagt seg på en praksis hvor terskelen for å iverksette undersøkelser og tiltak i et hjem er svært lav. Som en konsekvens overstiger saksmengden det de ansatte kan håndtere på en god måte. Det blir mer og mer åpenbart at mange familier opplever barnevernets inntreden i den private sfæren som svært dårlig begrunnet. Noen (etter hvert de fleste) på kontoret begynner å reflektere over at praksisen de har lagt seg på, er i ubalanse med deres egne og antatt allmenne rettferdighetsvurderinger. Det foreligger altså en situasjon med inkonsistens mellom prinsipper, praksiser og rettferdighetsvurderinger. La dette være en opptakt til det som følger nedenfor, hvor vi skal se nærmere på prinsippene barnevernet arbeider etter, og hvordan ideen om reflektert likevekt kan brukes når nevnte inkonsistenser oppstår.

\section{Barnevernets prinsipper}

Barnevern har en selvfølgelig plass blant grunnleggende samfunnsinstitusjoner i et moderne demokratisk samfunn, der barnet anerkjennes som en autonom person og med selvstendig moralsk verdi. En slik anerkjennelse ligger til grunn for at staten på legitimt vis etablerer og opprettholder institusjoner som beskytter barn mot overgrep og omsorgssvikt. Rawls sier dette om at samfunnet kan legge begrensninger for det indre livet i en familie:

Politiske prinsipper kan ikke anvendes direkte på familiens indre liv, men de legger viktige begrensninger på familien som institusjon og garanterer alle medlemmer grunnleggende rettigheter og friheter og en rimelig sjanselikhet. Dette gjør de ... ved å spesifisere de grunnleggende kravene som kan fremsettes av likeverdige borgere som er medlemmer av familier. Familien som en del av grunnstrukturen kan ikke krenke disse frihetene. (2003, s. 254) 
Norsk barneverns arbeid er tuftet på prinsipper som gir retning for vurderinger og beslutninger i konkrete saker. Prinsippene og fortolkninger av dem er formulert og presisert $i$ barnevernlovens forarbeider og rettsog forvaltningspraksis, og de er i så måte for juridiske prinsipper å regne. Men de hviler på moralske oppfatninger om hva som regnes å ha verdi hva som er viktig - for barn og familier, og dermed hvordan prinsippene bør nedfelles i beslutninger og begrunnelser. Og her ligger et konfliktpotensial: Barnevernets prinsipper er kompatible med ulike fortolkninger av hva som er viktig(st), og de kan dermed gi ulike svar på hva som er riktig å gjøre i konkrete tilfeller. Eirik C. Gundersen sier det slik:

The principles of child protection rest on certain assumptions of what is valuable for a child and a family.... these value assumptions are unclear: each principle can be interpreted in different ways and be consistent with a variety of different views about how the child should be treated. It is, in other words, not entirely clear what following these principles would imply. They provide different and possibly conflicting answers to the question of what we owe to children in public care. (Gundersen, 2018, s. 15)

Som nevnt innledningsvis er prinsippet om barnets beste helt grunnleggende for barnevernets arbeid. To øvrige prinsipper - det mildeste inngreps prinsipp og det biologiske prinsipp - regnes også som grunnleggende, men kan betraktes som fortolkninger av prinsippet om barnets beste. Slik sett kan disse to regnes som hjelpeprinsipper.

Samtidig som disse hjelpeprinsippene kan gjøre det enklere å bestemme hva som er et barns beste i en gitt situasjon, er det stort konfliktpotensial mellom førsteprinsippet om barnets beste og de to hjelpeprinsippene og også andre handlingsregler (andre prinsipper, lover, regler og retts- og forvaltningspraksis) barnevernet arbeider etter. Det er ofte svært krevende på en og samme tid å ivareta verdiene de ulike prinsipper og handlingsreglene reflekterer. Hvis ett prinsipp gis forrang i en bestemt sak, kan det bety at et annet gis mindre vekt eller settes til side. For eksempel kan prinsippet om at alle har rett til fritt å velge ektefelle ${ }^{7}$ potensielt komme i konflikt med prinsippet om at foreldre har rett til oppdra sine

7 Jf. FNs internasjonale konvensjon om sivile og politiske rettigheter, artikkel 23-3. 
barn $i$ henhold til sin kultur, religion og overbevisninger ${ }^{8}$. Det er vel kjent at barnevernet er involvert i saker der de må forholde seg til konflikter mellom ei tenåringsjente og foreldrene i saker der jenta ber om hjelp til å unngå uønsket giftemål eller tvangsekteskap. Dersom en slik konflikt ender med at barnevernet tar den unge jenta under sin beskyttelse, og sørger for at hun får opphold på hemmelig adresse, trumfer prinsippet om fritt partnervalg prinsippet om foreldres rett til oppdragelse etter egen overbevisning.

Barnevernets prinsipper og handlingsregler - eller fortolkningen av dem - varierer i tid og rom. De endrer seg i tråd med hvordan syn på barn og familie har utviklet seg gjennom historien, og de varierer mellom land i tråd med ulike kulturelle og religiøse syn på barn og familie. ${ }^{9}$ Når norsk barnevern gjennom en del år har fått - og får - mye internasjonal oppmerksomhet, er det blant annet fordi foreldre med ikke-norsk bakgrunn har problematisert barnevernets praksiser, særlig praksiser knyttet til omsorgsovertakelse. Krass kritikk blir reist fra foreldre og organisasjoner i ulike media og i gatedemonstrasjoner, særlig i øst- og sentraleuropeiske land (Brekke, Røssum \& Røren, 2016), og det finnes en rekke grupper i sosiale medier som har norsk barnevern som hatobjekt, for eksempel Facebook-gruppen «Norway, give us back the children you stole». ${ }^{10}$ Kjernen i kritikken er at barnevernets terskel for omsorgsovertakelse er for lav. Bak denne kritikken ligger en fortørnelse over barnevernets forståelse av prinsippet om barnets beste, og av hvordan omsorg og omsorgssvikt forstås.

Det er ikke til å undres over at foreldre som mener seg utsatt for urettferdig behandling, står opp med protester. Mer bemerkelsesverdig er det når eksperter i barnevernfeltet uttrykker kritikk. Tidligere dommer i Den europeiske menneskerettsdomstolen, Gro Hillestad Thune, er en hyppig kritiker av enkelte praksiser i norsk barnevern. I oktober 2018

8 Jf. FNs internasjonale konvensjon om sivile og politiske rettigheter, artikkel 18-4.

9 Se for eksempel Aurélie Picots «Out-of-Home Placement and Notions of Family in Norway and France» (2012) hva gjelder kulturelle forskjeller. For endring i forståelse av prinsippene over tid, se for eksempel Jorunn Gjedrems «Barnets beste» (2020), Solveig Botnen Eides «Barnets beste: Barnevernets formål i spenning mellom individuelle og relasjonelle hensyn» (2020), «Barnevernets biologiske prinsipp (2016) og «Det biologiske prinsippet» (2018). 
kommenterte hun for eksempel det faktum at 1805 barn ble tatt under barnevernets omsorg i 2017. I et intervju i NRK hevder hun at dette er for mange, at praksisen er brudd på loven, og at den må stoppes (NRK P2, 2018).

Denne kritikken, sammen med skuffende resultater av en rekke evalueringer av norsk barnevern, har bidratt til forsterket interesse for barnevernets praksiser fra politisk hold. Hva er det så som er feil med praksisene? Uten å gi noe generelt svar på spørsmålet skal jeg her anta at noen av problemene kan forklares med at prinsippene for barnevernets arbeid brukes på en forkjært måte, i den forstand at enkeltprinsipper blir tillagt for stor vekt og andre for lite vekt i konkrete saker. Resultatet er at helheten mistes av syne, og konsekvensene kan bli svært uheldige.

Jeg skal nå skissere en tenkt case som illustrerer at det er lett å miste helheten av syne når enkeltprinsipper får for stor vekt, og jeg skal vise hvordan Rawls' idé om reflektert likevekt kan brukes som metode for å skape bedre samsvar mellom prinsipper, praksiser og rettferdighetsvurderinger.

\section{Ravis møte med barnevernet}

Ravi, 16 år, går på videregående skole i en middels stor norsk by. Han er annengenerasjons innvandrer, enebarn, født i Norge to år etter at mor og far flyttet fra India. Ravi treffer ei jente han blir sammen med. Etter en stund forteller han til foreldrene at han har fått kjæreste, og at hun er etnisk norsk. Mor og far reagerer svært negativt på nyheten og forbyr ham å være sammen med jenta. Han får ikke lov til å gå ut om kvelden, og foreldrene truer med alvorlige sanksjonerer hvis han er ulydig, blant annet trusler om fysisk avstraffelse og langvarig opphold hos familie i India. Ravi, som er en sterk og selvstendig gutt, rømmer hjemmefra. Han får inntil videre bo hos en god kamerat.

Med hjelp av sosiallærer på skolen kontakter Ravi barnevernet. Barnevernet beslutter å igangsette undersøkelser på bakgrunn av Ravis opplysninger om truslene foreldrene har kommet med. Barnevernets saksbehandlere kontakter skole og helsestasjon for å kartlegge om de har opplysninger som kan gi grunn til mistanke om at Ravi har blitt eller blir utsatt for trusler om vold eller vold, eller om han får utilstrekkelig 
omsorg. Verken skolen han går på nå, eller barne- og ungdomsskolen han gikk på, har gitt opplysninger som tyder på noen form for omsorgssvikt. Tvert imot rapporterer skolene om en blid, utadvendt og godt fungerende gutt som er ivrig i skolearbeidet, og om foreldre som har samarbeidet godt med skolen og fulgt opp sønnen sin på en god måte.

Siden informasjonen barnevernet har, tyder på at problemene er begrenset til konsekvensene av Ravis kjæresteforhold, besluttes det å konsentrere videre saksgang om dette. Foreldrene blir invitert til møte. I samtalen blir foreldrene informert om at vold eller trusler om vold overfor barn er forbudt i henhold til norsk lov. Foreldrene forklarer på sin side at dette er akseptable oppdragelsesmetoder i deres kultur. De ønsker så inderlig at Ravi skal komme hjem igjen, så de går med på å avstå fra trusler om korporlig avstraffelse og andre sanksjoner, selv om kjæresteforholdet fortsetter. Etter samtalen med foreldrene har barnevernet et møte med Ravi hvor de formidler resultatet fra møtet med foreldrene. De anbefaler ham å flytte hjem igjen, basert på en antakelse om at Ravi, som jo er bare 16 år, vil ha det best ved å bo hjemme hos foreldrene sine. Alternativene, mener de, vil være mer inngripende - medføre store endringer og nye problemer - både for Ravi selv og for foreldrene.

Ravi går bare motstrebende med på å flytte hjem igjen. Han frykter at foreldrene ikke kommer til å holde ord, at de vil sette alt inn på å legge kjepper i hjulene for ham og kjæresten. Ravi ønsker ikke at frykten han bærer på skal formidles til foreldrene. Han ønsker ikke at de skal få inntrykk av at han ikke stoler på dem. Før han flytter hjem igjen, holdes et møte med foreldrene og Ravi sammen, der barnevernet oppsummerer hva man er blitt enige om. Det blir ikke sagt noe om Ravis engstelse.

Når Ravi har flyttet tilbake, viser det seg at foreldrene har bestemt at Ravi skal sendes til deres opprinnelige hjemland, ikke for en lengre periode, som de har truet med før, men for sommerferien som snart står for døren. De ønsker at han skal få bedre innsikt i foreldrenes kultur, og forhåpentligvis innse hvor viktig det er å fastholde de verdiene denne kulturen representerer - underforstått at det ikke vil være mulig dersom han har en etnisk norsk kjæreste. Ravi har gode relasjoner til familien i India, og han synes i og for seg det skal bli hyggelig å treffe dem igjen, selv om han synes målet med reisen er håpløst. Dessuten liker han dårlig at 
den er bestemt over hodet på ham. Under oppholdet blir det arrangert et møte med ei jente som introduseres som Ravis fremtidige ektefelle. Det er altså inngått avtale om at han om noen år skal gifte seg med jenta. Dette kommer som et sjokk på ham.

Tilbake i Norge eskalerer konflikten med foreldrene. Ravi vil ikke forholde seg til at det er planlagt et ekteskap. Han insisterer på sin rett til å velge fremtidig ektefelle selv, og til å velge hvem han skal være sammen med nå. Han opplever forholdene hjemme som uholdbare. Truslene forsterkes, og han føler seg etter hvert svært utrygg. Etter kort tid bestemmer han seg for å rømme hjemmefra på nytt. Han finner en liten hybel som han finansierer ved å ta arbeid noen kvelder i uken. Ravi ønsker ikke å oppsøke barnevernet igjen, ettersom han ikke synes han ble møtt med tilstrekkelig forståelse forrige gang. Han får hjelp av venner og venners foreldre til praktiske ting. Ravi kontakter Lånekassen for å høre om det finnes noen mulighet for borteboerstipend, selv om han bor under grensen på fire mil fra foreldrenes hjemsted. Lånekassen ber om en bekreftelse fra barnevernet om at de har behandlet en sak knyttet til Ravis situasjon. Barnevernet opplyser at de på grunn av taushetsplikten dessverre ikke kan gi Lånekassen en slik bekreftelse. Ravi får ikke borteboerstipend. Han får heller ikke penger til livsopphold av foreldrene, men greier så vidt å få det til å gå rundt med pengene han tjener.

\section{Reflektert likevekt - skisse av prosessen}

Hvilke prinsipper og handlingsregler illustreres i dette scenarioet? Som vi skal se, er det en hel rekke, men prinsippet om barnets beste, det mildeste inngreps prinsipp og det biologiske prinsipp er fremtredende. Prinsippet om barnets beste må vi anta ligger til grunn for barnevernets tilnærminger til saken. Barnevernets utgangspunkt er at vold eller trusler om vold overfor barn er svært fjernt fra barns beste - og dessuten forbudt. Barnevernet har altså hjemmel for å undersøke opplysningene Ravi gir dem. Dermed er legalitetsprinsippet, som sier at barnevernet skal ha juridisk hjemmel for virksomheten sin, ivaretatt.

Scenarioet illustrerer at det mildeste inngreps prinsipp og det biologiske prinsipp fungerer som hjelpeprinsipper for prinsippet om barnets 
beste. Barnevernet vurderer at det er best for Ravi å bo hjemme hos sitt biologiske opphav, til tross for at han er redd for hva som kan skje hvis han flytter hjem igjen. Barnevernet velger å feste lit til foreldrenes løfter om ikke å true med eller utføre vold, selv om kjæresteforholdet fortsetter. De ansatte på barnevernskontoret arbeider i en kontekst hvor det biologiske prinsipp står svært sterkt, både nasjonalt og lokalt. Prinsippet hviler på en antakelse om at det biologiske båndet mellom barn og foreldre representerer en verdi i seg selv. I dette konkrete tilfellet tilsier prinsippet at det er til Ravis beste at problemene han og foreldrene nå står i, løses innenfor rammen av familien. Det foreligger ikke opplysninger som skulle tilsi at det er andre problemer i familien. Barnevernet legger derfor til grunn at forsvarlighetsprinsippet, som også reflekteres i barnevernloven, er ivaretatt om han flytter hjem igjen. Av samme grunn ble det besluttet at hjelpetiltak ikke var nødvendig. Det ble riktignok vurdert om foreldrene skulle pålegges veiledning i andre oppdragelsesmetoder, men man kom til at det ikke var nødvendig ettersom foreldrene virket troverdige i sine løfter. Altså tolket saksbehandleren det mildeste inngreps prinsipp til kun å bety en påpekning av at vold og trusler om vold i oppdragelsesøyemed er forbudt.

Andre viktige prinsipper som vises i scenarioet, er barnets rett til å medvirke og barnevernets plikt til å samarbeide med barn og foreldre. Ravi har fått medvirke ved at han har hatt samtaler med saksbehandler alene. Prosedyrene er fulgt, og slik sett er prinsippet om barnets rettigheter i saksbehandlingen ivaretatt. Prosedyrerettferdighet er imidlertid én ting. En annen ting er den faktiske retten til medvirkning og retten til å bli lyttet til (jf. barnevernloven $\$ 1-6$ ). Ravi følte at han ikke nådde frem med sin frykt for at foreldrene kom til å sanksjonere, til tross for hva de lovet. Prinsippet om samarbeid med barn og foreldre (jf. barnevernloven $\S 1-7)$ er altså proseduralt ivaretatt, men i lys av hvordan scenarioet ender, kan det kan synes som om samarbeidet kunne vært bedre.

Prinsippet om barnevernets taushetsplikt finner vi også i scenarioet. Vi ser at prinsippet blir tolket på en måte som kommer i barnets disfavør. Barnevernet mener de ikke kan gi opplysninger til annen offentlig etat, i dette tilfellet Lånekassen, selv om opplysningene kunne ha sikret Ravi et bedre økonomisk fundament. 
La oss så undersøke hva slags samsvar det er mellom prinsipper, praksiser og rettferdighetsvurderinger - eller moralske intuisjoner - i scenarioet. Rent generelt er det godt samsvar mellom alle de prinsippene som illustreres, og våre moralske intuisjoner. Prinsippet om barnets beste, det mildeste inngrep, biologisk tilhørighet, forsvarlighet, medvirkning, retten til å bli lyttet til samt taushetsplikt er moralsk ikke-kontroversielle. Det er heller enkelte av praksisene, forstått som fortolkninger av prinsippene, som ikke samsvarer med våre moralske intuisjoner. Det er selvsagt ikke slik at alles moralske intuisjoner er helt like, stilt overfor konkrete tilfeller. Når jeg snakker om «våre» moralske intuisjoner, betyr det at det finnes noen moralske holdninger de fleste deler, og som fører til at vi reagerer på samme måte på konkrete situasjoner eller på spørsmål om rett og galt. Når vi eksempelvis observerer en voksen som skjeller ut et barn med de styggeste gloser, reagerer vi intuitivt og likt.

Praksisen rundt eller fortolkningen av taushetsplikten i scenarioet er et eksempel på ubalanse med våre moralske intuisjoner. Når det er slik at regelen om taushetsplikt tolkes på måter som fører til en praksis som går i barnets disfavør, vil vi - altså folk flest - mene at tolkningen stemmer dårlig overens med våre oppfatninger av hva som ville være rimelig og rettferdig. Vår moralske intuisjon sier at barnevernet burde ha opplyst Lånekassen om at det har vært en sak, og kanskje at de også kunne ha strukket seg til å bekrefte at de har kunnskap som tilsier at det kan være vanskelig for Ravi å bo hjemme.

Vi har altså å gjøre med en praksis som bør bringes i samsvar med moralske intuisjoner - som bør bringes i reflektert likevekt, for å si det med Rawls. I prosessen som fører frem til likevekt, må ulike faktorer kartlegges. Omfanget av en kartlegging vil variere med omfanget av praksisen. La oss si at den strenge fortolkningen av taushetsplikten i scenarioet er spesielt for akkurat dette barnevernskontoret. Da behøver kartleggingen ikke være spesielt omfattende. Det kan være tilstrekkelig at kollegiet sammen beslutter seg for å endre praksis fordi de erkjenner at den strenge fortolkningen fører til underminering av prinsippet om barnets beste.

Dersom den strenge fortolkningen derimot er i samsvar med praksis ved alle landets barnevernskontorer, og det etter hvert vokser frem en allmenn erkjennelse om at det finnes en ulikevekt mellom moralske 
intuisjoner og praksis knyttet til taushetsplikt mellom offentlige institusjoner, vil det kreve mer å bringe frem en reflektert likevekt. Et viktig spørsmål i prosessen vil være hvilket rom for skjønn som finnes innenfor jusens bestemmelser knyttet til taushetsplikt. Dersom det er slik at jusen er til hinder for å fremme barnets beste i denne konkrete - og i liknende saker, vil det kreves lov- eller regelendringer for å oppnå reflektert likevekt. Dersom jusen ikke er til hinder for en praksisendring, er veien til ny praksis mye kortere.

Praksisendring kan skje og utvikles gjennom de begrunnelsene som gis for beslutninger i enkeltsaker, og gjennom begrunnelser for praksiser på et mer generelt nivå. Hos Rawls henger ideen om reflektert likevekt sammen med ideen om offentlig begrunnelse. Denne ideen går ut på at begrunnelser som gis for lover, regelutforming, policyutforming, domsavsigelser og forvaltningsvedtak, skal baseres på en politisk rettferdighetsoppfatning og ikke på bestemte religiøse eller ikke-religiøse dogmer. «Politisk rettferdighetsoppfatning» betyr den oppfatningen om rettferdighet som over tid har vokst seg frem i liberale konstitusjonelle demokratier. Eksempelvis vil en begrunnelse om policyendring hva gjelder praksis for barnevernets taushetsplikt, måtte reflektere bestemmelser i konstitusjonelle dokumenter (Grunnloven) om hensynet til barnets beste. Dogmebaserte begrunnelser for en policyendring hører ikke hjemme i et konstitusjonelt demokrati, ifølge Rawls, fordi en slik begrunnelse vanskelig kan være noe alle kan slutte seg til. Et eksempel på en dogmebasert begrunnelse for en policyendring rundt taushetsplikten kan være dersom begrunnelsen refererer til religiøse holdninger eller skrifter hva gjelder hensyn til barnets beste.

\section{Sluttbemerkninger}

Gjennom scenarioet Ravis møte med barnevernet har jeg satt lys på hvordan ulike verdier, uttrykt gjennom prinsipper barnevernet jobber etter, lett kan komme i konflikt med hverandre. Casen viser også at når enkelte prinsipper gis for stor vekt på bekostning av andre, kan helheten mistes av syne, med den følge at en beslutning ikke er til barnets beste. Dessuten viser casen at tre faktorer kan komme i innbyrdes ubalanse: 1) prinsipper, 
2) praksiser som fortolkning av prinsippene og 3) våre allmenne rettferdighetsoppfatninger - eller moralske intuisjoner. Jeg foreslår at John Rawls' idé om reflektert likevekt kan brukes som modell for hvordan balanse kan gjenopprettes. De tre faktorene må prøves mot hverandre, både i den enkelte barnevernsinstitusjon eller det enkelte barnevernskontor og på nasjonalt policynivå.

\section{Referanser}

Brekke, E., Røssum, E. \& Røren, I. (2016, 6. februar). «Norway, stop child kidnapping!». Aftenposten, A-magasinet. Hentet fra https://www.aftenposten.no/amagasinet/i/ eEKO/Norway_-stop-child-kidnapping

Barnevernloven. (1992). Lov om barneverntjenester (LOV-1992-07-17-100). Hentet fra https://lovdata.no/dokument/NL/lov/1992-07-17-100

De forente nasjoner. (1966). FNs konvensjon om sivile og politiske rettigheter (norsk oversettelse av International Covenant on Civil and Political Rights). Hentet fra https://www.fn.no/om-fn/avtaler/Menneskerettigheter/Konvensjon-om-sivileog-politiske-rettigheter

Gundersen, E. C. (2018). What we owe to our children. (Avhandling, Skriftserien 2018, nr. 22). Oslo: OsloMet.

Eide, S. B. (2016). Barnevernets biologiske prinsipp. I T. Mesel \& P. Leer-Salvesen (Red.), Moralske borgere (s. 128-148). Oslo: Portal forlag.

Eide, S. B. (2018). Det biologiske prinsippet. I T. A. Ask \& S. B. Eide (Red.), Barnevernets begreper - $i$ bevegelse (s. 45-6o). Oslo: Gyldendal Akademisk.

Eide, S. B. (2020). Barnets beste: Barnevernets formål i spenning mellom individuelle og relasjonelle hensyn. I O. Lysaker \& T. E. Fredwall (Red.), Verdier $i$ konflikt: Etikk i et mangfoldig samfunn (s. 121-139). Oslo: Cappelen Damm Akademisk.

Gjedrem, J. (2020). Barnets beste. I T. A. Ask \& S. Eide (Red.), Barnevernets begreper $i$ bevegelse (s. 63-80). Oslo: Gyldendal Akademisk.

Picot, A. (2012). Out-of-home placement and notions of family in Norway and France. Sosiologi i dag, 42(3-4), 13-35.

Norway, Give Us Back the Children You Stole. [Facebookside]. Hentet fra https:// www.facebook.com/search/str/norway+give+us+back+the+children+you+stole/ keywords_search

NRK P2. (2018, 3. oktober). Nyhetsmorgen [Radioprogram]. Hentet fra https://radio. nrk.no/serie/nyhetsmorgen/NPUB32019718/03-10-2018 
Nuse, I. P. (oversetter). (2018, 10. februar). Protests mount against Norwegian Child Welfare Service. ScienceNordic. Hentet fra http://sciencenordic.com/protestsmount-against-norwegian-child-welfare-service

Rawls, J. (1985). Justice as fairness: Political not metaphysical. Philosophy and Public Affairs, 14(3), 223-251.

Rawls, J. (1993). Political liberalism. New York: Columbia University Press.

Rawls, J. (1971/1999). A Theory of justice (rev. utg.). Cambridge, MA: The Belknap Press of Harvard University Press.

Rawls, J. (2003). Rettferdighet som rimelighet. Oslo: Pax Forlag.

United Nations High Commissioner for Refugees. (2008). UNCHR Guidelines on Determining the Best Interest of the Child. Hentet fra http://www.unhcr.org/ 4566b16b2.pdf 



\title{
KAPITTEL 4
}

\section{Verdier og kommunikasjon i konfliktsituasjoner}

\author{
Halvor Nordby \\ Professor, Høgskolen i Innlandet
}

\begin{abstract}
Good communication between child protection workers and families is crucial for cooperation and agreement about decisions regarding child care. This chapter focuses on challenges in this communication related to value conflicts conflicts in which fundamental disagreement is grounded in opposing values. The chapter uses concepts from philosophy of mind and language to understand value conflicts in child protection services. The key theoretical idea is that beliefs and thoughts are different from value preferences. While beliefs and thoughts are mental representations that are true or false depending on how the world is, persons' values are preferences directly related to activities or objects that are of fundamental importance to them. This means that telling others, explicitly or implicitly, that their values are false involves a categorical mistake and will typically be experienced as a form of value imperialism that undermines cooperation and aims of shared understanding in child protection work. Value preferences related to child care can nevertheless be explored and challenged in various ways, for instance by focusing on tensions between values, or on beliefs that values are grounded in. The chapter uses case studies to clarify these implications in professional child protection.
\end{abstract}

Keywords: values, conflicts, communication, shared understanding

\section{Innledning}

Barnevernets samarbeid med barn og unge og deres omsorgspersoner blir spesielt utfordrende når det oppstår verdikonflikter - konflikter der uenighet skyldes grunnleggende verdimotsetninger. Dette kapitlet

Sitering av denne artikkelen: Nordby, H. (2020). Verdier og kommunikasjon i konfliktsituasjoner. I H. Nordby \& A. Halsa (Red.), Verdier i barnevern (Kap. 4, s. 67-87). Oslo: Cappelen Damm Akademisk. https://doi.org/10.23865/noasp.103.ch4 Lisens: CC BY-ND 4.0 
bruker moderne språk- og bevissthetsteori fra filosofi til å diskutere hvordan disse konfliktene kan forstås, og hvordan de kan håndteres.

Den teoretiske grunnideen som anvendes, er at tanker og oppfatninger er noe annet enn verdipreferanser: Mens tanker og oppfatninger er holdninger til påstander som er sanne eller usanne, så er verdiene våre direkte knyttet til ting og aktiviteter vi mener det er viktig å ivareta og realisere (Stigen, 1979; Peacocke, 1992; Guttenplan, 1995; Raz, 2003). Denne forskjellen innebærer at det ikke er mulig å vise andre at verdiene deres er objektivt uriktige, på samme måte som det kan være mulig å vise at en uriktig oppfatning er usann. Å snakke konstruktivt om andres verdipreferanser i barnevernarbeid kan like fullt gjøres ved å problematisere spenninger mellom verdier eller ved å utforske det faktiske grunnlaget for verdipreferanser.

Kapitlet drøfter hvordan denne typen utforskning av verdier i håndtering av verdikonflikter kan skape refleksjon «innenfra» - ved at de som barnevernet jobber med, opplever det som riktig å utforske egne verdipreferanser ut fra sine egne ståsteder. Samtidig kan dialog og refleksjon rundt verdier medføre at barnevernsarbeidere opplever at deres egne personlige eller profesjonsrelaterte verdier blir utfordret på en måte som gjør at de reviderer grunnlaget for vurderinger eller beslutninger. Kapitlet bruker eksempler til å belyse hvordan typiske verdikonflikter i barnevern kan forebygges og håndteres gjennom dialog.

\section{Bakgrunn}

Dette kapitlet er en anvendt diskusjon. Målet er å bruke grunnleggende antakelser i moderne språk og bevissthetsfilosofi til å forstå et avgrenset område - verdikonflikter i barnevern. Dermed er det i første omgang naturlig å klargjøre begrepene som skal anvendes, og området som skal forstås.

Selve ideen om en konflikt har blitt forstått på mange måter. Generelt finnes det mange definisjoner av konfliktbegrepet (Blandhol, 2014). Noen knytter konflikter opp mot uenighet, slik at nær sagt all uenighet faller inn under konfliktbegrepet (Høst, 2014). Andre krever mer, som at en eller begge parter i tillegg anvender makt for å få gjennomslag for 
sitt syn (Ekeland, 2014). Jeg har selv utviklet en mellomposisjon, der en konflikt forstås som en situasjon der «[t]o eller flere personer som er avhengige av hverandre er i en konflikt hvis de er så uenige om en sak at det har betydelig negativ effekt på samarbeidet dem imellom» (Nordby, 2017, s. 38).

Ingen av analysene her vil forutsette en presis forståelse av begreper som «betydelig negativ effekt», men definisjonen kan like fullt være en klargjørende ramme. Slik jeg forstår konfliktbegrepet, krever en konflikt mer enn uenighet. Men det er ikke nødvendig at den ene parten faktisk utøver makt. Det er tilstrekkelig at uenigheten har en betydelig negativ effekt på samarbeid.

\section{Verdikonflikter}

Det finnes ulike typer av konflikter. De fleste har hørt uttrykket «verdikonflikt», men også betegnelser som «interessekonflikt», «rollekonflikt» og «personkonflikt». Å forstå hvilken konflikttype - eller konflikttyper en konfliktsituasjon involverer, er viktig i konflikthåndtering (Blandhol, 2014; Nordby, 2017). Håndtering av en rollekonflikt, for eksempel, krever en annen tilnærming enn håndtering av en personkonflikt. Når det gjelder verdikonflikter, som dette kapitlet handler om, kan man si at de oppstår når partene i en konflikt har motstridende verdier som former handlingspreferansene deres - oppfatningene de har om hvordan det er riktig å handle (Nordby, 2017).

Merk at denne forståelsen åpner opp for at det kan være ulike typer av verdier som står på spill i en verdikonflikt. Introduksjonskapitlet til denne boken skilte mellom samfunnsverdier, kulturelle verdier og personlige verdier (se introduksjonskapitlet for en nærmere forklaring), og alle kan gi opphav til verdikonflikter.

Faktisk har alle de mulige verdikonfliktene en slående relevans i barnevern. Det kan oppstå konfliktsituasjoner der en eller begge parter er opptatt av samfunnsverdier, situasjoner der en eller begge parter er opptatt av kulturelle verdier, og situasjoner der grunnleggende uenighet skyldes personlige verdier som verken kan sies å være samfunnsverdier eller kulturelle verdier. 


\section{Barnevern}

For å forstå nærmere hvordan verdikonflikter typisk oppstår i barnevernarbeid, kan det være hensiktsmessig å ta utgangspunkt i en klarere forståelse av hvordan barnevernarbeid er verdiladet.

I utgangspunktet er barnevernarbeid - som en profesjonell praksis tungt styrt av samfunnsverdier. Et fundamentalt samfunnsoppdrag for barnevernet er å realisere grunnleggende verdier som er beskrevet i norsk lov, og da spesielt i barnevernloven. ${ }^{1}$ Med lovendringen som kom i 2018, kan man blant annet merke seg at en verdi som kjærlighet nå er inne i den aller første paragrafen i barnevernloven.

I tillegg til verdiene som direkte er beskrevet i lovverket, finnes det andre samfunnsverdier som kan knyttes til barnevernarbeid. Det er interessant å se hvordan ulike verdier har blitt fremhevet opp gjennom den ideologiske historien til barnevernet (Larsen, 2004; Herberg \& Kvaran, 2019). I dag ser vi blant annet hvordan barns rett til medvirkning stadig betones sterkere (Paulsen \& Studsrød, 2019). Denne type ideologiske endringer kan resultere i revideringer av lovtekster som tar mål av seg til å fange opp endringene. Generelt kan man se på lovtekster som formuleringer om hvordan grunnleggende samfunnsverdier i samfunnet skal ivaretas. Det betyr også at lovverket kan være på etterskudd - hvis det ikke raskt nok fanger opp endringer i verdiene.

Selv om dette nok mer er et teoretisk enn et praktisk poeng, så er det verdt å huske, også for hver enkelt barnevernarbeider, at lovene som er sentrale i barnevernet, ikke er hugget i stein. Det er viktig at de som jobber i førstelinje, melder tilbake når de opplever at juridiske føringer ikke oppleves som riktige i konkrete situasjoner. Mange nok tilbakemeldinger om at lovverket ikke gir «riktige svar» i bestemte typer av situasjoner, kan føre til at lovverket revideres. Merk at det nødvendigvis må være noe annet enn lovverket - og typisk etiske vurderinger - som utgjør grunnlaget for vurderinger av hvorvidt lovverket gir riktige svar (Nordby, Bennin \& Buer, 2013).

Selv om samfunnsverdier, slik de typisk er nedfelt i lovverket, kan komme i konflikt med barnevernsarbeideres egne etiske overbevisninger,

https://lovdata.no/dokument/NL/lov/1992-07-17-100 
er det nok vanligere at barnevernsarbeidere opplever at samfunnsverdiene, som en ramme for barnevernets arbeid, kommer i konflikt med verdiene til de barnevernet jobber med. Det er nettopp denne spenningen som typisk skaper opplevde verdikonflikter i barnevernarbeid. De profesjonelle opplever at verdiene barnevernet er satt til å ivareta, ikke passer med verdiene til dem de jobber med. ${ }^{2}$

\section{Et innledende eksempel}

Det er ikke vanskelig å forstå at hvis verdimotsetninger i barnevernarbeid ikke håndteres med omhu, hvis barnevernsarbeidere allerede i utgangspunktet tar rollen som den parten som har de «riktige» verdiene, kan det være vanskelig å skape grobunn for dialog og endring. Her er et innledende eksempel:

Barnevernet har mottatt bekymringsmelding om to søsken på ni og elleve år. Det er skolen barna går på, som har sendt inn meldingen. Lærere og helsesøster er bekymret for omsorgssituasjonen for barna. Barna har lite kontakt med medelever, de virker redde og engstelige og er mye alene. Barna har blant annet fortalt at foreldrene blir svært strenge når de har gjort noe galt, og at de ofte gruer seg til å gå hjem. Jenta på ni år har flere ganger spurt kontaktlærer om hun kan være med henne hjem etter skolen. Lærerne har forsøkt å snakke med barnas foreldre om barnas situasjon, men opplever at det er svært vanskelig å skape dialog.

Barneverntjenesten i kommunen går etter hvert inn med foreldresamtaler og foreldreveiledning. De er opptatt av å formidle til foreldrene at de er bekymret for omsorgssituasjonen til barna. Saksbehandler sier til foreldrene at han er engstelig for at omsorgspraksisene og barnas utrygghet kan ha uheldige konsekvenser for barna. Han ber foreldrene tenke på samspillsituasjoner med barna, og hvordan barna opplever disse situasjonene.

Oppfordringene til refleksjon gir ikke ønsket resultat. I dialogen med foreldrene kommer det frem at de har et syn på oppdragelse som gir barna liten

2 Jeg bruker «de barnevernet jobber med» som en samlebetegnelse. Barnevernet kan jobbe med barn, ungdom og/eller familiene deres og også med andre omsorgspersoner. Det vil være enkelt å forstå hvordan poengene i dette kapitlet er relevante i alle relasjonene. 
frihet til å bestemme over egen hverdag. Foreldrene sier at barna blir oppdratt slik de selv har blitt oppdratt, og at slik de selv tenker om oppdragelse, så er dette en riktig måte å oppdra barna på. De sier at de er klar over at deres syn på oppdragelse ikke samsvarer med det mange andre mener, men at de ikke gjør noe straffbart, og at de må få lov til å oppdra barna i samsvar med den tradisjonen de er vant med. De sier også at de kjenner andre familier der barna etter hvert har hatt store utfordringer i oppveksten fordi de ikke har fått en god nok oppdragelse.

I dette eksemplet mener foreldrene at praksisene deres er begrunnet fordi de er forankret i et sosialt fellesskap. De er nedfelt i et sett av sosiale verdier - normer foreldrene slutter seg til fordi de selv har lært dem, og fordi de opplever dem som riktige for dem.

Barneverntjenestens syn, kan vi anta, er farget av en fagorientering innen utviklingspsykologi, sosialpedagogikk og tilknytningsteori. Barneverntjenesten er opptatt av trygghet for barna, barnas personlige og sosiale utvikling og at barna skal ha gode relasjoner til omsorgspersoner. Disse verdiene er en sentral del av barneverntjenesten profesjonskultur. Vi kan også anta at barneverntjenesten mener det er en reell risiko for at barna har fått eller får utviklingstraumer, at foreldrene har brukt og vil bruke fysisk makt overfor barna, og at barneverntjenesten har et helt grunnleggende samfunnsmandat for å avverge dette.

\section{Verdier og oppfatninger}

Hvordan skal denne og andre typer av verdikonflikter i barnevern mer presist forstås? De analytiske brillene jeg vil bruke for å forstå verdikonflikter i barnevern, er hentet fra moderne kognitiv psykologi og språk- og bevissthetsfilosofi. Det jeg først og fremst vil være opptatt av, er hvordan disse fagretningene analyserer tanker og oppfatninger som mentale representasjoner av verden, og hvordan denne analysen ikke kan brukes til å forstå verdier som holdninger til praksiser.

I den internasjonale faglitteraturen er «propositional attitudes» - proposisjonale holdninger på norsk - det vanlige uttrykket for å betegne oppfatninger og tanker (Peacocke, 1992; Davies, 1995; Guttenplan, 1995; 
Nordby, 2005). Ideen er at oppfatninger og tanker er mentale holdninger til påstander om verden. Ta som et eksempel min oppfatning om at jorda er rund: Jeg tror at jorda er rund. Dette blir forstått som en type holdning - det å tro noe - til en bestemt påstand - at jorda er rund. Det jeg tror, er sant hvis jorda er rund, og usant hvis jorda ikke er rund. Jeg kan også tenke at jorda er rund. Det er en annen type holdning til den samme påstanden. En person som tror at jorda er flat, kan i prinsippet tenke at jorda er rund, uten å tro at jorda er rund.

Det finnes mange ulike mentale holdninger til påstander, og det finnes et uendelig antall påstander vi kan ha holdninger til (Davies, 1995; Guttenplan, 1995). Mye kan sies om innholdet og omfanget av proposisjonale holdninger, men det faller utenfor det som er sentralt her. Det viktige poenget er at oppfatninger og tanker er mentale representasjoner med sannhetsverdi - de er sanne eller usanne avhengig av hvordan den indre eller ytre verdenen er (avhengig av om vi har oppfatninger om vårt eget mentale liv eller om verden rundt oss).

Mange filosofer har vært opptatt av at strukturen i proposisjonale holdninger kommer til uttrykk i språket vårt når vi tilskriver andre oppfatninger (Nordby, 2005). Det vil si at når vi sier ting som «Knut tror at jorda er rund», så tilskriver vi Knut en holdning (det å tro noe) til en påstand (at jorda er rund). Det vi mener, er at Knut har en sann oppfatning hvis det som kommer etter ordet «at», er sant, og en usann oppfatning hvis det som kommer etter ordet «at», er usant.

\section{Verdipreferanser}

Det er et slående trekk ved mange av verdiene våre at de ikke kan forstås som holdninger til påstander, slik vi kan forstå tanker og oppfatninger. Grunnen er at mye av det vi er opptatt av i livet vårt, det vi ønsker å vare på og realisere, ikke er påstander vi tror er sanne, men aktiviteter og ting i verden som er viktige for oss.

For å forstå denne grunnleggende forskjellen mellom en persons oppfatninger og det vi kan kalle «verdipreferanser» nærmere, kan vi ta utgangspunkt $\mathrm{i}$ ideen om hva det vil si for en person å være opptatt av verdier. Det finnes ikke noen allmenn avgrenset definisjon av hva en verdi er 
for en person, litt fordi ordet «verdi», slik det forstås i dagligspråket, både kan være et substantiv og et adjektiv (og dermed referere til både ting og egenskaper). De aller fleste som har forsøkt å avgrense verdibegrepet, vil imidlertid godta at det å være opptatt av verdier handler om mer enn å tro at noe er sant. Å ha verdipreferanser handler om hvordan vi ønsker å leve (Rokeach 1973; Busch 2012).

I norsk litteratur har filosofen Anfinn Stigen (1979, s. 23) formulert en definisjon som har fått innflytelse, og som får frem poenget: «De egentlige verdier er de ting som gir innhold i tilværelsen. Verdier er det et menneske strever etter å oppnå hvis det ikke har det, eller som det anstrenger seg for å beholde eller bevare.» Lars Gunnar Lingås (2008, s. 85) har en lignende definisjon. Han definerer verdier som «materielle og immaterielle tilstander og gjenstander som er ... avgjørende viktig å fremme, å sikre eller å ta i bruk». Også denne bekrivelsen knytter verdier til praksiser. Verdier er ikke bare noe vi tror om verden. De er, som Wallace påpeker, knyttet til «objects and activities ... things that are profoundly shaped by social practices» (Wallace, 2003, s. 4). På samme måte er filosofen Wittgenstein i sin innflytelsesrike Culture and Value (1980) opptatt av at verdipraksiser er «måter å leve på» - hvordan vi faktisk lever, og hvordan vi ønsker å leve.

\section{$\AA$ At tilskrive andre verdier}

Vi kan få frem poenget med at verdipreferansene våre ikke er oppfatninger ved å tenke på ting som har høy verdi for oss, som noe vi verdsetter. Vi kan si ting som «Kari verdsetter å være sammen med familien» eller «Knut verdsetter å være ute i naturen». Men da tilskriver vi ikke Kari eller Knut holdninger til påstander. Poenget ligger helt fremme i språket vi bruker (Nordby, 2005). Etter ordet «å» i tilskrivelsene følger en ufullstendig setning som refererer til en aktivitet («å være sammen med familien», «å være ute i naturen»). Disse uttrykkene er ikke påstander som er sanne eller usanne, slik som det som følger etter ordet «at» i en oppfatningstilskrivelse.

Dermed, når vi sier «Kari verdsetter å være sammen med familien», så gir det ikke mening å si at den preferansen vi tilskriver Kari, er sann eller 
usann. Sagt på en annen måte: Hvis Kari sier «jeg liker å være sammen med familien», så kan vi ikke si at Kari tar feil, med mindre vi mener at Kari mangler selvinnsikt i hvilke preferanser hun reelt sett har. Gitt at vi mener at Kari ikke tar feil om dette, så kan vi heller ikke si at hun har en «uriktig» eller «usann» verdipreferanse. Vi relaterer Kari direkte til en aktivitet vi mener er viktig for henne, ikke en representasjon av verden (som kunne vært usann). Det vi mener å si, er at hun liker å holde på med noe bestemt som er verdifullt for henne.

\section{Verdier og forståelseshorisonter}

Det at verdipreferansene våre er knyttet til aktiviteter og praksiser - slik at de i seg selv ikke er mentale representasjoner - betyr ikke at de er løsrevet fra oppfatningene våre. For det første har vi oppfatninger om hvilke verdier vi har. Så lenge Kari har kognitiv kontakt med preferansene sine i eksemplet over, vil hun ha en oppfatning om at hun verdsetter å være sammen med familien når hun faktisk verdsetter å være sammen med familien.

For det andre er mange av verdipreferansene våre påvirket av den totale forståelseshorisonten vår, det vil si «summen av den totale mengden av oppfatninger og holdninger som vi har på et gitt tidspunkt, bevisste og ubevisste, og som vi ikke har vår oppmerksomhet rettet mot» (Føllesdal \& Walløe, 2003, s. 95). Mange av verdiene våre er forankret i tanker og oppfatninger. Hvis tankene og oppfatningene vi har, forandres, eller andre deler av forståelseshorisontene våre forandres, så kan verdiene våre forandres.

Et typisk eksempel kan være en aktivitet man forstår er usunn. En person kan like mye hard skitrening, men hvis han eller hun ikke lenger tror at mye hard skigåing er rimelig sunt fordi det øker risikoen for hjerteflimmer, kan det føre til at personen i langt mindre grad verdsetter dette. Et annet eksempel kan være en person som verdsetter å reise mye rundt i verden. Kunnskap om hvor mye flyreiser forurenser kan gjøre at personen ikke lenger verdsetter denne aktiviteten i like stor grad. På samme måte, hvis det skjer store faktiske forandringer i Karis liv i eksemplet over, vil kanskje ikke det å være sammen med familien bety så mye for henne.

Forankringen av verdier i forståelseshorisonter er viktig, fordi den forklarer hvordan det noen ganger kan være mulig å få en person til å 
forme nye verdier ved å vise personen at han eller hun har en ubegrunnet oppfatning eller ganske enkelt tar feil om noe. Noen ganger kan det også skje at en person rett og slett former nye preferanser uten noen spesiell grunn. Man kan bli interessert i noe man før ikke var spesielt interessert i, kanskje bare fordi tiden går, eller fordi man blir eldre. Eller man kan bli mindre interessert i å gjøre noe man tidligere var mer interessert i, rett og slett fordi man får nye interesser.

Det er i korthet mange måter verdiene våre kan forandres på, og det faller utenfor målet her å beskrive alle. Det analytiske hovedpoenget har vært å peke på en slags kortslutning i dialog, som på mange måter representerer en ubegrunnet form for maktutøvelse: Det som alltid blir ubegrunnet, er å forholde seg til andres verdier som om de er objektivt usanne i seg selv, som om de er usanne tanker eller oppfatninger. Dette kan spesielt lett skje hvis man definerer egne verdipreferanser som «sanne» - som om de er oppfatninger som representerer objektive saksforhold i verden.

\section{Verdikonflikter i barnevern}

Poenget om å skille mellom oppfatninger og verdier har en slående relevans i barnevern. Barnevernarbeid er gjennomsyret av normativitet: Både de som jobber i barnevernet, og de som er i kontakt med barnevernet, handler - verbalt og nonverbalt - ut fra preferanser om hva som er «god omsorg» og andre verdiladede begreper (Eide, 2019). Det innebærer at hvis for eksempel en familie har andre preferanser enn det barnevernet legger til grunn, og hvis barnevernsarbeidere ikke forstår og anerkjenner dette i arbeidet med familien, så kan familien lett oppleve at grunnlaget de har for egne verdipraksiser, ikke blir respektert. Det kan igjen føre til konflikteskalering, dårlig samarbeid og til sjuende og sist betydelige negative konsekvenser for barnet.

Det er nok ikke vanlig at de barnevernet jobber med, bruker den filosofiske analysen aktivt i egne forståelser av hva som skjer når egne preferanser ikke blir forstått eller anerkjent som viktige for dem. Men vi kan alle kjenne igjen opplevelsen av at andre moraliserer over hvordan vi bør leve livet vårt - eller hva vi egentlig bør gjøre - uten at vi opplever å ha fått 
en god begrunnelse. Det er nettopp dette som lett kan skje når forskjellen mellom oppfatninger og verdier ikke anerkjennes i barnevernarbeid.

Dermed er det heller ikke vanskelig å forstå hvordan analysen av forskjellen på verdier og oppfatninger legger føringer på hvordan verdikonflikter i barnevern kan håndteres. En typisk verdikonflikt $\mathrm{i}$ barnevern er av den typen som ble nevnt over: Foreldre opplever at omsorgspraksisene deres er forankret $i$ et sett av verdier som gjør at praksisene er bra (eller i det minste akseptable) for barna deres, mens barneverntjenesten mener at praksisene ikke er bra nok.

I alle konflikter av denne typen vil analysen over ha den samme konsekvensen: Det som blir «feil», er å formidle en forståelse av at aktivitetene foreldrene verdsetter, er uriktige i seg selv - som om verdiene var usanne. Det vil stort sett bare forsterke motstand, skape dårlig samarbeid og medføre konflikteskalering. Og jo mer konflikter eskalerer, desto vanskeligere er det å håndtere dem (Ekeland, 2014; Nordby, 2017). Til sjuende og sist blir det vanskeligere å finne løsninger til det beste for barnet.

\section{Hode mot hode?}

For å illustrere hvordan manglende forståelse av verdimotsetninger kan føre til stadig dårligere samarbeid, kan vi bruke det innledende eksemplet jeg gav over om ulike syn på oppdragelse, og tenke oss at det fortsetter som følger:

I samtaler med foreldrene forklarer barneverntjenesten at de er bekymret for samspillet mellom foreldrene og barna og for barnas helhetlige omsorgssituasjon. De gir også foreldrene en sterk oppfordring om å delta i et foreldreveiledningsprogram som de forklarer at heter «COS-P». Foreldrene klarer ikke helt å forstå hva «samspill» eller «COS-P» er, men begynner etter hvert å bli svært redde for at hvis de ikke later som de forstår, eller gjør de «riktige» tingene, slik de oppfatter at barneverntjenesten definerer hva som er riktig, så vil de risikere at barnevernet, som de ellers har hørt mye negativt om, tar barna deres fra dem. De er dypt uenige med barneverntjenesten, ikke bare i tiltakene barneverntjenesten foreslår, men til og med i virkelighetsbeskrivelsene de opplever at barneverntjenesten gir. De er imidlertid engstelige for å si ifra, av frykt for å miste omsorgen for egne barn. 
Ut fra et kommunikasjonsperspektiv er problemet åpenbart: Det å formidle bekymring for omsorgen til foreldrene, og det å gi foreldrene en sterk oppfordring om å ta imot foreldreveiledning, innebærer at man ikke anerkjenner at foreldrene faktisk opplever egne omsorgspraksiser som akseptable.

I eksemplet kan vi anta at barneverntjenesten i svært begrenset grad forsøker å gi noen nærmere argumenter eller forklaringer. Forståelsen foreldrene sitter igjen med, er at barneverntjenesten forteller dem at de rett og slett tar feil når de tror at omsorgen er god nok. Dette er ikke et godt utgangspunkt for dialog - når den andre parten i utgangspunktet mener å ha gode grunner for et annet syn. Foreldrene opplever ikke at barneverntjenesten gjør noe reelt forsøk på å komme under overflaten ved å forsøke å finne en slags nøytral grunn og diskutere på en mer likeverdig måte hva som er best for barna.

I denne situasjonen står barneverntjenesten og foreldrene hode mot hode, og som den profesjonelle parten har barneverntjenesten et hovedansvar for å skape dialog. Familien føler seg presset og har ikke engang fritt valgt å samarbeide - de opplever et stort press. Relasjonen er vertikal, avstanden er stor, og maktforholdet er enormt. Et naturlig mål i en situasjon som denne er å forstå og snakke om grunnlaget for familiens preferanser. Dette er et profesjonsmål i seg selv - i tråd med den danske filosofen Løgstrups (200o) kjente ideal om å møte andre med tillit, oppriktighet og en interesse for å forstå. Uten en interesse for dette, og en sensitivitet for hva som ligger under akkurat denne familiens preferanser, er det vanskelig å skape dialog.

En grunnleggende mangel på forståelse er i seg selv negativt. Det kan også prege samarbeidet om å finne løsninger for barnet det er snakk om, og det kan ha negative konsekvenser som ikke er i barnets beste interesser. Som eksemplet understreker, er det heller ikke alltid indre motstand synes så godt. De barneverntjenesten jobber med, kan innrette seg fordi maktforholdet er så enormt, og fordi de føler seg presset (Nordstoga, 2004).

Enda sterkere blir presset når et tiltak ikke lenger er frivillig, men påtvunget. Det kan nettopp være dårlig kommunikasjon som gjør at en konfliktsituasjon eskalerer så mye at påtvungne hjelpetiltak anses som 
nødvendig. Forstått på denne måten har barneverntjenesten et betydelig ansvar for å kommunisere godt rundt verdimotsetninger tidlig - i henhold til mildeste inngreps prinsipp. Satt på spissen: Formen på dialogen kan i seg selv forsterke maktutøvelsen.

\section{Konstruktiv dialog}

Jeg har så langt rettet oppmerksomheten mest mot det negative som kan skje hvis dialogen rundt verdimotsetninger ikke er god. Jeg mener ikke at eksemplet over er representativt, eller at verdiladet dialog mer generelt ofte er dårlig i barnevernarbeid. Poenget har vært å synliggjøre en fallgruve man kan havne i. Det å ha en bevissthet om verdier kan være til hjelp for å forstå hvordan man kan unngå å trå feil, slik at man heller legger til rette for konstruktiv dialog. Men det å tenke verdibevisst kan også gi en begrepsmessig forståelse av hvorfor ting går bra - i alle situasjoner der kommunikasjon rundt verdimotsetninger er god.

I lys av det begrepsmessige rammeverket jeg har presentert, handler det sistnevnte i stor grad om at man finner avgjørende forbindelser mellom verdier og forståelseshorisonter. Det at verdier er forankret i forståelseshorisonter, betyr at det kan være mulig å snakke konstruktivt om omsorgspersoners verdier ved å stimulere til refleksjon «innenfra». Et sentralt mål blir å avklare hvilke tanker og oppfatninger som ligger til grunn for en verdipraksis. Man kan typisk stille seg spørsmål som: Kan det være at noen av omsorgspersonenes oppfatninger er ubegrunnet, på en måte som gjør at omsorgspersonene selv reviderer grunnlaget for egne verdipraksiser hvis de oppdager at oppfatningene er ubegrunnet? Kan man gi informasjon som gjør at de revurderer egne praksiser? Kan de bli mer klar over spenninger mellom egne verdier?

Prinsippet om forståelse i konflikthåndtering er spesielt viktig for å finne nye innfallsvinkler for refleksjon. $\AA$ utforske nye perspektiver sammen, ut fra den forståelsen andre allerede har, kan være helt avgjørende for endring av preferanser. Her er et nytt tenkt eksempel:

Barnevernet jobber med en familie der det har vært mange utfordringer rundt barnas omsorgssituasjon. En av de tingene barneverntjenesten snakker med 
familien om, er ordninger med leksehjelp på skolen og skolefritidsordningen (SFO). Foreldrene er først skeptiske. De er vant til at barna er mye hjemme, og de synes det er rart at barna skal være igjen på skolen etter at skolen egentlig har sluttet. For dem er det naturlig at barna kommer rett hjem. Foreldrene forklarer at det er dette de er vant til, at mange andre familier de kjenner, har det på samme måte, og at det er slik de ønsker å ha det. De sier også at de har hørt mange negative ting om SFO. Barneverntjenesten sier at de kan forstå usikkerheten, men gir likevel, i et språk foreldrene forstår, mer informasjon om hvordan leksehjelp kan være nyttig, og om hvordan barn kan ha utbytte av å være sammen med andre barn i SFO. Etter hvert forandrer foreldrene oppfatning. De forstår at de ikke har hatt en fullgod forståelse av ordningene, de blir mer positive, og det ender med at de sier at de gjerne vil forsøke. Det viser seg at både barneverntjenesten og foreldrene opplever at deltakelse i ordningene har en positiv effekt på barnas totale omsorgssituasjon.

Eksemplet illustrerer hvordan det å formidle informasjon kan medføre skifte av preferanser. Da barneverntjenesten ga foreldrene en bedre forståelse av hva ordningene med SFO og leksehjelp innebar, så førte det til et skifte av preferanser «nedenfra». Preferansene hvilte på et sett av oppfatninger som forandret seg, og da forandret også verdiene seg.

I denne situasjonen fremsto barneverntjenesten mer som beslutningstilrettelegger enn som beslutningstaker. Konflikten ble løst tidlig, og nøkkelen var å realitetsorientere foreldrene på en måte foreldrene opplevde som imøtekommende og konstruktiv. Hvis barneverntjenesten ikke hadde møtt foreldrene på denne måten, kunne konflikten lett ha eskalert, med de konsekvensene det ville ha fått.

Eksemplet illustrerer også et annet poeng: Det å formidle kunnskap kan gi - eller utvide - en felles situasjonsforståelse som kan utgjøre en nøytral felles grunn for dialog fordi forståelsen blir en virkelighetsbeskrivelse begge parter kjenner seg igjen i. I kommunikasjonsteori anses det å ha et felles saksforhold å forholde seg til som viktig i likeverdig dialog. Noen filosofier har også gått så langt at de mener at mennesker ikke kan forstå hverandre med mindre de har et sett av felles oppfatninger om noen av de tingene de snakker om (Føllesdal \& Walløe, 2003). Et beslektet argument har vært at reell uenighet bare kan oppstå hvis man er enige om en del av det man diskuterer. 
Denne type filosofiske analyser av grunnlaget for dialog kan være et godt utgangspunkt for å reflektere over kommunikasjonspraksiser i profesjonelle kontekster. Jeg har allerede understreket at jeg på ingen måte antar at profesjonsutøvere i barnevernet ikke er gode til å håndtere konflikter. Men begrepene jeg har brukt, kan bidra til å gjøre det enda tydeligere hvordan verdikonflikter oppstår, og hvordan de kan håndteres.

\section{Å forstå verdipraksiser}

En betingelse for all konflikthåndtering er å oppnå en rimelig god forståelse av andre i første omgang. I kommunikasjonsteori har dette blitt knyttet til det å ha sympati med andres standpunkter. Hvis andres synspunkter eller praksiser fremstår som fullstendig ubegrunnet eller irrasjonelle, så har man sannsynligvis ikke forstått dem særlig godt.

Konkret knyttes denne ideen ofte til Gadamers ideal om enighet som det primære målet for forståelse, og også til Habermas sin teori om en herredømmefri dialog og tanken om at mennesker har den samme evnen til å se det fornuftige i en sak (Roderick, 1986; Warnke, 1987). I konfliktsituasjoner innebærer dette at det er nødvendig å komme inn i den andre partens logikk for å kunne snakke om konflikten på en konstruktiv måte (Nordby, 2017).

En sentral teoretisk føring fra denne type teorier er at hvis det for barnevernsarbeidere fremstår som «fullstendig ubegripelig» at omsorgspersoner gjør (eller ikke gjør) noe, eller hvis man konkluderer med at omsorgspersoner overhodet «ikke har skjønt sitt eget eller barnets beste», så har man egentlig ikke forstått dem i første omgang. Kanskje man ikke engang har gjort et reelt forsøk på å forstå dem i det hele tatt?

Det samme gjelder i verdikonflikter. Teorier som knytter mål for dialog til enighet (eller i det minste oppklarende uenighet) og interesse av å forstå andre «innenfra», vil implisere at det er det nødvendig å ha en åpen innstilling til andres standpunkter for å forstå motparten i første omgang.

\section{Utforskende ferdigheter}

På mange måter faller målet om å forstå andres grunner for å handle verbalt eller nonverbalt inn under det å ha utforskende kommunikasjonsferdigheter. 
Også når det gjelder verdier, kan man direkte stille spørsmål som «hva er viktig for dere?» eller «hva tenker dere er gode løsninger?». Etter utforskninger som dette, som selvsagt vil preges av konteksten man er i, gjenstår spørsmålet om det er riktig å utfordre verdiene som er avdekket, og i så fall hvordan.

Hvis overstyring av andres verdier blir en form for maktutøvelse, er det rimelig at begrunnelsen må knyttes til hva som står på spill - hva som blir de negative konsekvensene av å la andre få leve i samsvar med verdiene sine. I barnevern vil «negative konsekvenser» åpenbart knyttes til ideen om «barnets beste». Det må være i barnets beste interesse at barneverntjenesten ikke etterkommer barnets eller omsorgspersoners ønsker om å utøve omsorg på en bestemt måte. I tillegg vil vurderinger rundt autonomi være relevante. I den pliktetiske tradisjonen fra filosofen Kant er det et grunnleggende prinsipp at jo mer andres ønsker er autonome, desto mer skal de respekteres, selv om man kanskje selv tenker at noe annet hadde vært enda bedre for den eller de det gjelder (Nordby, Bennin \& Buer, 2013).

Mer generelt krever all maktutøvelse i barnevernarbeid en helt tydelig begrunnelse. Det er ikke tilstrekkelig å henvise til mer eller mindre generelle og vage («tradisjonelle norske»?) normer for hva som er en akseptabel måte å leve på. Det er nødvendig å kunne henvise til noe mer, noe som kan knyttes til poenget om å unngå uforholdsmessig negative konsekvenser for barnet (Nordby, Bennin \& Buer, 2013). Man må huske at det etter hvert har blitt store krav til begrunnelse og dokumentasjon i barnevernarbeid. ${ }^{3}$ Disse kravene gjelder selvsagt også barnevernets håndtering av verdikonflikter. Det er ikke tilstrekkelig å forankre overstyring av andres verdier i en ren skjønnsmessig vurdering. Det er nødvendig å sannsynliggjøre at det foreligger risiko for alvorlig negative konsekvenser for barnet hvis man ikke respekterer en families omsorgspraksiser. Man kan også si at jo større maktutøvelsen er, desto mer må stå på spill for barnet.

\footnotetext{
3 Se for eksempel Helsetilsynets gjennomgang av barnevernssaker: https://www.helsetilsynet.no/ globalassets/opplastinger/publikasjoner/rapporter2019/helsetilsynet_rapport_unummerert_ gjennomgang_106_barnevernsaker.pdf
} 
Men hva som er skadelig for et barn, kan være vanskelig å vurdere (Follesø, 2019). Vi kan som et eksempel tenke oss en familie med to små barn som lever isolert, langt fra nærmeste tettsted. Familien har en alternativ livsstil, de lever svært nøysomt, og de har lite kontakt med andre. Naboer er bekymret for barna og har sendt melding til barnevernet.

Som person kan saksbehandler ha en helt annen livsstil enn familien, men i en sak som denne må man spørre seg hvor mye som står på spill. Kanskje det å leve på den måten familien gjør, ikke er så skadelig for barna? Og hvis det vurderes som skadelig, hvilken forståelse av «skadelig» er det som legges til grunn? Er det en forståelse som i stor nok grad anerkjenner at det kan være mange ulike meninger om hva som er skadelig? Er det en forståelse foreldrene kjenner seg igjen i?

Forstått på denne måten handler det å være bevisst på verdiladede praksiser like mye om å rette blikket innover som om å rette det utover. Spørsmålet man kan stille seg, er om man kan gi en god begrunnelse for å problematisere en families preferanser, en grunn som i det minste overbeviser en selv om at det er riktig å gjøre det. Kanskje resultatet av en selvransakelse blir at man ikke finner grunnlag for å være så kritisk til en families livsstil som det man opprinnelig var? Eller i det minste at man forstår verdimotsetningene bedre, slik at man blir mer oppmerksom på å snakke om verdier på en mer likeverdig og konstruktiv måte?

\section{Individets egne preferanser}

Til sjuende og sist skal barnevernsarbeidere ivareta barna eller ungdommene de jobber med. Hvordan dette vurderes, vil selvsagt avhenge av muligheter og begrensninger ved hver situasjon, men det er alltid barnet eller ungdommen selv som skal være i sentrum.

For å understreke betydningen av å være oppmerksom på verdipreferanser i det direkte arbeidet med barn og unge, og også illustrere bredden i barnevernarbeid, vil jeg som et siste eksempel bruke en tenkt situasjon fra vanlig miljøterapeutisk arbeid.

Knut, som bor på en barneverninstitusjon, bruker mye tid foran PC-skjermen og velger ofte dataspill som aktivitet når han har mulighet. Flere av miljøterapeutene 
som jobber ved institusjonen, er skeptiske til Knuts interesse. De tenker at det hadde vært bra for Knut om han brukte enda mer tid på sosialt samvær med andre, og de oppmuntrer ham til å være med på andre aktiviteter som er en del av institusjonens tilbud til ungdommene som bor der. Det hender Knut blir med, men han søker stadig tilbake til interessen for dataspill.

Knuts primærkontakt bestemmer seg for å snakke grundig med Knut om det primærkontakten opplever som utfordringer rundt spillingen. I samtalen de har, forandrer primærkontakten sitt syn på Knuts aktivitet. Han forstår at Knut har et reflektert og bevisst syn på sin egen interesse. Knut forteller at han for så vidt liker å være sammen med de andre ungdommene og de som jobber ved institusjonen, men at han trenger tiden for seg selv. Knut understreker at spillingen ikke går ut over de daglige rutinene og pliktene han har. I samtalen blir det også klart at Knut har fått mange gode venner gjennom spillingen, og at spillingen gir ham mestringsfølelse, sosial anerkjennelse og trening i å konsentrere seg og tenke analytisk. Knut viser primærkontakten hvordan spillet fungerer, primærkontakten blir fascinert, og det hele ender med at de noen ganger spiller sammen, som en felles aktivitet.

Det å stå overfor ungdommer som ønsker å holde på med aktiviteter som ikke oppfattes som de mest «sunne» eller «oppbyggelige» er ikke uvanlige situasjoner på barnevernsinstitusjoner. Nettopp derfor er det viktig å ha et reflektert forhold til hva som bør aksepteres. Det er selvsagt ikke slik at alle preferanser skal respekteres. Poenget er at det som profesjonelle ut fra sine forståelseshorisonter kan vurdere som lite optimalt i utgangspunktet, noen ganger kan fortone seg som et mer bevisst og gjennomtenkt valg som til og med kan ha positive konsekvenser for barnet eller ungdommen det gjelder. ${ }^{4}$

I eksemplet over kan vi tenke oss at det å etterkomme Knuts preferanser ikke brøt med reglene på institusjonen, og at dette bidro til at det opplevdes som enklere å innrette seg etter preferansene. Det kan selvsagt også oppstå situasjoner der barns eller unges preferanser gjør at regler og systembaserte verdier blir utfordret. Hvis man velger å etterkomme

4 Og kanskje det noen ganger kan være riktig å godta barns og unges preferanser, selv om man, som profesjonell, mener konsekvensene ikke blir gode? Dette berører store og viktige spørsmål om omfanget av individets rett til å bestemme over eget liv, selv på en barneverninstitusjon. Å diskutere dette mer prinsipielt faller dessverre utenfor rammene for dette kapitlet. 
preferansene i situasjoner av denne typen, er det viktig å ha en god begrunnelse. Et eksempel kan være en situasjon der det å overholde «husregler» betyr mindre enn å hindre dramatisk konflikteskalering med betydelige negative konsekvenser.

Generelt er det like fullt forståelig at barnevernsarbeidere kan synes det er utfordrende å handle i samsvar med egne etiske vurderinger som ikke passer med formelle rammene de jobber innenfor. Samtidig er det igjen, som understreket ovenfor, viktig å minne om den profesjonsetiske plikten til å melde fra. Hvis en barnevernarbeider mener at regler for praksis gjør det umulig å etterkomme barns eller unges preferanser, men samtidig mener at det er riktig å etterkomme preferansene, så bør man i det minste skape bevisstgjøring rundt dette i egen organisasjon. Tilbakemeldingene fra de som jobber direkte med barn og unge, er helt avgjørende for å videreutvikle virksomheten som en verdibevisst praksis. Dette krever i første omgang at det eksisterer en organisasjonskultur som gjør at hver enkelt opplever det som trygt og meningsfullt å melde inn egne vurderinger. Deretter må vurderingene bli en del av den systembaserte tenkningen om hvordan virksomhetens praksiser faktisk skal være verdibasert. $^{5}$

\section{Avslutning}

Skillet mellom fakta og verdier er fundamentalt i filosofihistorien. I dette kapitlet har jeg analysert distinksjonen i lys av språk og bevissthetsfilosofi og brukt den til å si noe om hvordan verdikonflikter oppstår og kan håndteres i barnevern.

Mye mer enn det jeg har rukket her, kan selvsagt sies om verdikonflikter i barnevern. Målet har vært å beskrive en kjerne av tematikken, og å introdusere begreper som faktisk legger ganske store føringer for praksis. Hovedpoenget har vært at man ikke kan rasjonalisere bort andres verdipreferanser som om de er usanne.

Det å anerkjenne at barnevern er verdiladet, er viktig i en tid der det er stadig mer oppmerksomhet på begrunnelser i denne delen av sosialt

$5 \AA$ A ivareta disse betingelsene er i stor grad et lederansvar. 
arbeid (Christiansen \& Kojan, 2016). Å begrunne en empirisk påstand om verden er en ting. Ofte kan man henvise til evidensbasert kunnskap kanskje forskning - som bygger opp under det man mener er sant. Å begrunne en verdiladet påstand er derimot noe annet. Det finnes ikke noen tilsvarende enkel fremgangsmåte.

Dessverre er det sjelden dette kommer frem i debatten om begrunnelse og dokumentasjon i barnevern. Begrepet om begrunnelse forstås noen ganger i en relativt smal forstand som forskningsbasert eller evidensbasert belegg - ofte knyttet til empirisk forskning. Problemet er at dette fort kan være en for smal ramme. Barnevernarbeid er ikke bare et svært komplekst område som mangler en hard naturvitenskaplig (somatisk) kjerne. Det er også gjennomsyret av normativitet.

Å tenke begrunnelse bare ut fra personlig eller forskningsbasert empirisk kunnskap, uten å anerkjenne at barnevernarbeid er verdiladet, fanger ikke inn behovet for å tenke annerledes i arbeid med å forebygge, avverge og håndtere verdikonflikter. Å tenke for smalt empirisk gjør det vanskeligere å kommunisere, og det underminerer samarbeid mot løsninger. Til sjuende og sist blir det vanskelig å finne løsninger som er i barnets beste interesser.

\section{Litteratur}

Blandhol, S. (2014). Konfliktanalyse. Bergen: Fagbokforlaget.

Busch, T. (2012). Verdibasert ledelse i offentlige profesjoner. Bergen: Fagbokforlaget.

Christiansen, Ø. \& Kojan, B. H. (2016). Beslutninger i barnevernet. Oslo:

Universitetsforlaget.

Davies, M. (1995). Philosophy of mind. I A. C. Grayling (Red.), Philosophy - a guide through the subject (s. 250-336). Oxford, England: Oxford University Press.

Eide, S. B. \& Oltedal, S. (2015). Verdiers betydning for vår forståelse og vår handling. I I. T. Ellingsen, I. Levin, B. Berg \& L. C. Kleppe (Red.), Sosialt arbeid (s. 8o-96). Oslo: Universitetsforlaget.

Eide, S. B. (2019). Etikk i barnevernet. I I. Kvaran, I. Studsrød, V. Paulsen \& K. Mevik (Red.), Barnevernpedagogen (s. 66-77). Oslo: Universitetsforlaget.

Ekeland, T.-J. (2014). Konflikt og konfliktforståelse (2. utg.). Oslo: Gyldendal Akademisk.

Follesø, R. (2019). Risiko, svev og tilhørighet. Hvilken betydning har ordene vi bruker i en barnevernsfaglig sammenheng? I I. Kvaran, I. Studsrød, V. Paulsen \& K. Mevik (Red.), Barnevernpedagogen (s. 113-121). Oslo: Universitetsforlaget. 
Føllesdal, D. \& Walløe, L. (2003). Argumentasjonsteori, språk og vitenskapsfilosofi. Oslo: Universitetsforlaget.

Guttenplan, S. (1995). A companion to the philosophy of mind. Hoboken, NJ: WileyBlackwell.

Herberg, E. B. \& Kvaran, I. (2019). Barnevernspedagogutdanningen og profesjonsutøvelsen i historisk perspektiv. I I. Kvaran, I. Studsrød, V. Paulsen \& K. Mevik (Red.), Barnevernpedagogen (s. 39-52). Oslo: Universitetsforlaget.

Høst, T. (2014). Ledelse i helse- og sosialsektoren (3. utg.). Oslo: Universitetsforlaget.

Larsen, M. Y. (2004). Barnets rettslige stilling i barnevernloven og barneloven. I T. Havik, M. Y. Larsen, S. Nordstoga \& J. Veland (Red), Barnevernet: forutsetninger og gjennomføring (s. 15-56). Oslo: Universitetsforlaget.

Lingås, L. G. (2008). Etikk og verdivalg i helse- og sosialfag (4. utg.). Oslo: Gyldendal Akademisk.

Løgstrup, K. E. (2000). Den etiske fordring. Oslo: Cappelen Damm.

Nordby, H. (2005). Begrepsbeherskelse og oppfatningstilskrivelser, Norsk filosofisk tidsskrift, $40(2), 116-123$.

Nordby, H. (2008). Values, cultural identity and communication: A perspective from philosophy of language. Journal of Intercultural Communication, 17(6). http:// www.immi.se/intercultural/nr17/nordby.htm

Nordby, H., Bennin, C. \& Buer, B. A. (2013). Etikk i barnevern. Oslo: Gyldendal Akademisk.

Nordby, H. (2017). Konflikthåndtering for ledere. Oslo: Gyldendal Akademisk.

Nordstoga, S. (2004). Barnevernarbeiderens makt. I T. Havik, M. Y. Larsen, S. Nordstoga \& J. Veland (Red.), Barnevernet: forutsetninger og gjennomføring (s. 119-126). Oslo: Universitetsforlaget.

Paulsen, V. \& Studsrød, I. (2019). Barnet i sentrum i barnevernspedagogens yrkesutøvelse. I I. Kvaran, I. Studsrød, V. Paulsen \& K. Mevik (Red.), Barnevernpedagog. En grunnbok (s. 25-36). Oslo: Universitetsforlaget.

Peacocke, C. (1992). A Study of concepts. Cambridge, MA: MIT Press.

Raz, J. (2003). The practice of value. I J. Raz \& R. Wallace (Red.), The practice of value (s. 15-63). Oxford, England: Oxford University Press.

Roderick, R. (1986). Habermas and the foundations of critical theory. London, England: Macmillan.

Rokeach, M. (1973). The nature of human values. New York: The Free Press.

Stigen, A. (1979). Filosofiske tekster. Oslo: Pax.

Wallace, R. (2003). Introduction. I J. Raz \& R. Wallace (Red.), The practice of value, (s. 1-15). Oxford, England: Oxford University Press.

Warnke, G. (1987). Gadamer: Hermeneutics, tradition and reason. Stanford, CA: Stanford University Press.

Wittgenstein, L. (1980). Culture and value. Oxford, England: Basil Blackwell. 



\title{
KAPITTEL 5
}

\section{Kulturelle verdier og barnevernet: Ulike forståelser av «barnets beste»}

\author{
Mari Rysst \\ Professor, Høgskolen i Innlandet
}

\begin{abstract}
In this chapter I discuss cultural values related to child protection services (CPS). More precisely, I focus on professionals working in CPS and their relationship and meetings with families of immigrant origins. These meetings often reflect different cultural values and understandings of "the best interest of the child" and may cause tensions and misunderstandings. In the Norwegian CPS system, professionals have to draw on professional and personal experiences in decisions concerning the "best interest of the child". This chapter uses concepts and perspectives from psychological anthropology to throw light on these processes. This is because these perspectives show how ideas and experiences are internalized and embodied as dispositions in habitus that may motivate certain actions when professionals and immigrant families meet. I also discuss whether some reactions and advice from professionals may be understood as ethnocentric because Norwegian parenting values are presented as "better" than parenting values from other countries.
\end{abstract}

Keywords: psychological anthropology, embodiment, tensions, ethnocentric practice

\section{Innledning}

Det er politikerne som lager prinsippene og rammeverket for barnevernets beslutninger, mens det er de som arbeider på ulike nivåer i barnevernsystemet som fatter beslutningene om hva som er omsorgssvikt, hva som er uforsvarlig omsorg og hva som er skadelig for barn. Når profesjonelle og legfolk skal prøve å si noe hvor grensen går mellom forsvarlig og uforsvarlig omsorg, så er det

Sitering av denne artikkelen: Rysst, M. (2020). Kulturelle verdier og barnevernet: Ulike forståelser av «barnets beste». I H. Nordby \& A. Halsa (Red.), Verdier i barnevern (Kap. 5, s. 89-111). Oslo: Cappelen Damm Akademisk. https://doi.org/10.23865/noasp.103.ch5

Lisens: CC BY-ND 4.0 
basert på kunnskap om hva barn trenger, og normative oppfatninger av hva som er en god barndom. (Læret \& Skivenes, 2016, s. 37, første utheving min, siste linjene opprinnelig)

Dette sitatet introduserer på en sammenfattet måte tematikken i dette kapitlet. Jeg skal diskutere kunnskaps- og verdigrunnlaget samt normative oppfatninger knyttet til forståelsen av «barnets beste» hos både profesjonelle og legfolk (foreldre). Begrepet «kunnskapsbasert praksis» er et begrep som ofte brukes i barnevernet og andre velferdstjenester som et kvalitetsstempel (Nordstoga, 2018, s. 233), og som i dette kapitlet forstås å omfatte kunnskaps- og verdigrunnlaget i barnevernet. Forståelsen av «barnets beste» omfatter blant annet hva som er omsorgssvikt, hva som er uforsvarlig omsorg, og hva som er skadelig for barn. Vurderinger av dette er basert på kunnskap og normative oppfatninger eller skjønn. Prinsippet om «the best interest of the child» ble slått fast av FNs barnekonvensjon i 1989 (artikkel 3), som Norge har forpliktet seg til å følge opp.

Utgangspunktet for dette kapitlet er den økte migrasjonsstrømmen til Norge og resten av Europa de siste tiår, og det faktum at forskning har vist en overrepresentasjon av barn og unge med minoritetsbakgrunn i barnevernsstatistikken. Familier med migrantbakgrunn utgjør flertallet av familier som får hjelpetiltak av barnevernet (Berg et al., 2017, s. ix). Mitt fokus i dette kapitlet er imidlertid først og fremst å presentere en teoretisk tilnærming for å forstå de spenninger som kan oppstå mellom verdier hos barnevernets profesjonsutøvere og verdier familier med immigrantbakgrunn har angående «barnets beste».

I norsk sammenheng eksisterer det i dag en del forskning om innvandrere og barnevernet (se f.eks. NOU 2012: 5; Fylkesnes, Iversen, Bjørknes \& Nygren, 2015; Aarset \& Bredal, 2018; Berg et al., 2017; Studsrød \& Tuastad, 2017; NOU 2017: 12; Bufdir, 2019a). Media og noe forskning (NOU 2016: 16) har i den senere tid rettet søkelyset mot konflikter mellom barnevern og familier med både etnisk norsk og utenlandsk bakgrunn. Ulik forståelse av barnets beste kan ligge til grunn for slike konflikter. Avvikende forståelser peker på eksistensen av ulike kulturelle verdier knyttet til barn, omsorg og oppvekstsvilkår. Ifølge Læret og Skivenes (2016) legges det lite føringer for hvordan beslutningstakere skal forstå barnets beste. Derfor blir det ofte opp til beslutningstakernes (barnevernsarbeidere, 
fylkesnemndas medlemmer, dommere) skjønn og dømmekraftå bestemme hva som i hver sak er barnets beste (Læret \& Skivenes, 2016, s. 36). Sagt på en annen måte har beslutningstakere i Norge, som i Sveits og Estland, fått vide fullmakter til å bruke skjønn. Dette er ikke tilfellet i land som Finland, Australia og England (Læret \& Skivenes, 2016, s. 36). Det er nettopp denne muligheten til bruk av skjønn og subjektiv dømmekraft som gjør at jeg finner tematikken skissert for dette kapitlet, interessant. Det er fordi det kan være relevant å forstå hvilke verdigrunnlag dette skjønnet og denne dømmekraften har utspring i.

Skjønnet og dømmekraften til utdannede barnevernsarbeidere er i stor grad formet og strukturert gjennom utdanningen. Men alle som jobber i tjenesten, er også påvirket av de kollegaer de til enhver tid samarbeider med. Kåre Heggen og Silje Louise Dahl (2017) konkluderer i artikkelen «Barnevernets kunnskapsgrunnlag» at erfaringsbasert kunnskap i egen barneverntjeneste har mye å si for hvordan saker blir behandlet. De hevder at «kontor-interne ressursar og oppfatningar speler ei viktigare rolle for barnevernsarbeidet enn kunnskapsgrunnlaget frå utdanning og forsking» (Heggen \& Dahl, 2017, s. 80). Det synes også som et faktum (dog gjennom media) at det eksisterer ulik praksis fra sted til sted, noe som illustrerer at bruk av personlig skjønn må forekomme i tolkning av både lover, regler og situasjoner.

I tråd med dette diskuterer som nevnt Sigrid Nordstoga (2018) begrepet «kunnskapsbasert praksis» i relasjon til barnevernet, et begrep hun altså mener ofte brukes i barnevernet og andre velferdstjenester som et kvalitetsstempel (Nordstoga, 2018, s. 233). Hun hevder videre at betydningen av den personlige dimensjonen i yrkesutøvelsen ikke blir tatt nok hensyn til i forståelsen av kunnskapsbasert praksis (som presenteres utfyllende senere i kapitlet). Nordstoga mener at profesjonsutøveres beslutninger påvirkes av verdivalg, og at det personavhengige skjønnet kan styrke at gode beslutninger tas til barnets beste. Hun hevder at «måten profesjonsutøveren utfører og fortolker praksis på, er en betydningsfull side som er lite ivaretatt når kunnskapsbasert praksis blir fremhevet som retningsgivende for et godt barnevern» (Nordstoga, 2018, s. 249). Med andre ord argumenter hun for at vi bør ha større oppmerksomhet på betydningen av personlige, erfaringsbaserte verdiers innflytelse på møter mellom 
profesjonelle og «brukerne», noe som resonerer godt med min argumentasjon i dette kapitlet.

Verdier er knyttet til normer og tilegnes gjennom sosialisering i ulike sosiale kontekster gjennom hele livsløpet. Ifølge antropolog Roy D’Andrade er begrepet «verdi» knyttet til noe som oppfattes som godt eller bra, noe positivt (D’Andrade, 2008, s. 11). Når en verdi betraktes som god og viktig, blir den sannsynligvis internalisert og virker da ofte motiverende for handling (D’Andrade, 2008, s. 11). Dette er i tråd med det Halvor Nordby skriver om i sitt kapittel i denne boken, nemlig at våre preferanser for ulike verdier er knyttet til ting og aktiviteter vi mener det er viktig å ivareta og sette ut i livet (se Nordbys kapittel 4 i denne boken), altså at verdier fører til handling.

Kulturelle verdier knyttet til barn, omsorg og oppdragelse kommer frem i ulike norske institusjoner i møtene mellom fagfolk og foreldre med både etnisk norsk og utenlandsk bakgrunn. Migranter blir for eksempel fulgt opp av myndigheter kort tid etter ankomst, og de får et sted å bo mens de venter på utfallet av sin asylsøknad. Både disse og de som har vært i landet en stund, får tilbud om oppfølging via helsestasjon og tilbud om barnehage og skole til sine barn. Det er i disse kontekstene forhold i hjemmesituasjonen kan komme frem, og der spenninger kan oppstå mellom profesjonsutøvere (her: helsesykepleiere, barnehagelærere, lærere) og familiene, som i neste omgang kan føre til at bekymringsmelding sendes barnevernet. Profesjonsutøvere har en juridisk plikt til å melde fra til barnevernet dersom de mistenker at «et barn blir mishandlet i hjemmet», at «det foreligger andre former for alvorlig omsorgssvikt», eller hvis «et barn har vist vedvarende alvorlige adferdsvansker» (Bufdir, 2019a). Eventuelle oppståtte spenninger illustrerer koblingen mellom begrepene «foreldreskap» og «barndom» (Sparrman, Westerling, Lind \& Dannesboe, 2016).

Ulike forstålser av barnets beste må ikke være knyttet til etnisk opprinnelse, men kan også ha forankring i ulik sosioøkonomisk bakgrunn hos både fagfolk og foreldre. Forskning viser for eksempel at fagfolk har en tendens til å tenke at det er foreldrenes situasjon som er årsaken til omsorgssvikt i lavinntektsfamilier, mens det er selve barnet som tenderer å være problemet i middelklassefamilier (Kojan, 2010). Likeledes kommer barnevernet mye senere på banen i middelklassefamilier, det vil si når 
barnet er godt oppe i skolealder (Kojan, 2010). Og barns rett til å bli hørt blir ekstra viktig dess eldre barna blir. I det følgende skal jeg bruke møter mellom profesjonsutøvere og foreldre til barn og unge som eksempler, altså der eventuelle bekymringsmeldinger kommer fra helsestasjon, barnehage eller skole, og jeg spør:

Hvordan kan eventuelle spenninger i møtet mellom profesjonsutøvere i barneomsorg og foreldre forstås med fokus på kulturelle verdier knyttet til «barnets beste»?

Dette spørsmålet skal besvares i lys av perspektiver fra psykologisk antropologi, mer presist det som omtales som «skjemateori» og kulturelle modeller (Quinn, 2018). Jeg skal hovedsakelig bruke empiriske eksempler fra sosialantropolog Ida Erstads doktorgradsavhandling (2015) om pakistanske mødre og familier i Norge, men også eksempler fra norsk barnevern. Mer presist bruker jeg empiri fra Erstad og andre som data, som jeg omfortolker med begrepsapparatet fra psykologisk antropologi i lys av min problemstilling. Med «profesjonsutøvere i barneomsorg» mener jeg profesjonelle i helsestasjon, barnehage og barnevern. Min hovedinteresse er prosessene frem til bekymringsmelding sendes og undersøkelse og møter settes i gang. Jeg mener at møtene mellom helsesykepleiere og foreldre samt barnevernsarbeider og foreldre har viktige paralleller, fordi i begge situasjoner er det forståelsen av barnets beste som er i sentrum. Og denne forståelsen er i begge tilfeller motivert av kulturelle modeller eller verdier.

Diskusjonen i dette kapitlet frembringer ingen ny empirisk kunnskap, men omfortolker noe av det som allerede finnes av relevant litteratur. Kapitlet vil presentere et annerledes perspektiv for å forstå kulturmøter mellom ulike profesjonsutøvere i norsk barneomsorg og foreldre, det være seg i helsestasjon, barnehage eller barnevern. Jeg er opptatt av bakgrunnen for hvordan bekymringsmeldinger kan bli sendt til barnevernet, med påfølgende kulturmøter mellom profesjonsutøvere og foreldre, der eventuelle spenninger kan oppstå og beslutninger tas. Det «nye» i dette kapitlet er det teoretiske blikket, der jeg prøver å forstå eventuelle spenninger i møter mellom profesjonsutøvere og foreldre med minoritetsbakgrunn i lys av perspektiver fra psykologisk antropologi, eller - mer 
presist - hvordan internaliserte kulturelle modeller og kroppslige erfaringer, særlig om barnets beste, kan være motiverende for handling. Jeg vil understreke at kapitlet er eksplorativt i mangel på data om profesjonsutøveres og foreldres konkrete bakgrunn. Kanskje kan perspektivet inspirere lesere til å anvende det presenterte teoretiske blikket i fremtidig forskning?

I det følgende skal jeg først presentere det overordnede teoretiske perspektivet som, sammen med begrepet «barnets beste», blir en rød tråd gjennom hele kapitlet. Dernest presenteres det jeg oppfatter som grunnleggende norske verdier som profesjonsutøvere og foreldre kan ha internalisert, og som kan motivere dem til handling. Til slutt anvendes dette i diskusjonen om mulige spenningsforhold mellom profesjonsutøvere og foreldre.

\section{Kulturelle modeller og kroppsliggjort kultur}

Profesjonsutøvere i helsestasjon og barnevern samt familiene de har kontakt med, møtes med ulike erfaringer, kunnskap, tanker og følelser rundt den konkrete situasjonen rundt barnet. De profesjonelle har sin bakgrunn fra dagligliv og kunnskapsbasert praksis, og familiene kommer med ulik personlig og faglig ballast. Felles for dem alle er at deres forståelser og handlinger angående barn er motivert av noe, av bevisste eller ubevisste tankemønstre. Med handlinger tenker jeg her først og fremst på bekymringsmeldinger, saksfremlegg og beslutninger (profesjonsutøverne) og reaksjoner på disse (foreldrene eller familiene).

Ifølge antropolog David Kronenfeld representerer interessen for teoretisering rundt «kulturelle modeller» eller «skjemaer» en videreføring av amerikansk antropologis interesse for verdier, men med stor oppmerksomhet på de strukturer eller mekanismer som knytter verdier til målsetninger, motivasjoner og slik til handling (Kronenfeld, 1996, s. 17). Psykologisk og kognitiv orientert antropologi har et teoretisk rammeverk knyttet til praksis og motivasjon gjennom teorier om internalisering av kognitive skjemaer, som videre er knyttet til teoretisering omkring kroppsliggjort kultur (Shore, 1996; Spiro, 1997; D’Andrade, 1989; D’Andrade \& Strauss, 1992; Strauss \& Quinn, 1997; Bloch, 1992; Csordas, 
1990; Connerton, 1989). Utgangspunktet for en slik forståelse er hvordan menneskers kognitive prosesser forstås. Skjemateori har et ontologisk utgangspunkt om at hjernen fungerer gjennom assosiative nettverk bestående av nevroner. Et kognitivt skjema er et erfaringsavtrykk i hjernen, omtalt som representasjoner, med assosiative nettverk. En slik teori ble først lansert av forskere på kunstig intelligens, en tilnærming de kalte for «connectionism» (Quinn, Sirota, Stromberg, 2018, s. 294). En slik forståelse av hjernens virksomhet innebærer at forbindelser mellom nevroner blir styrket gjennom aktivitet, og vice versa vil forbindelser svekkes hvis de forblir inaktive. En av de første som oppdaget denne funksjonen, sa at «neurons that fire together wire together» (Quinn et al., 2018, s. 294). Antropologene Claudia Strauss og Naomi Quinn har utviklet skjemateori videre og foreslår at når to eller flere personer har samme eller lignende erfaringer, får de samme eller lignende avtrykk eller representasjoner av erfaringen. Dette kaller de for kulturelle skjemaer eller modeller, som er i tråd med slik Roy D’Andrade definerer kulturell modell: «[A] cognitive schema that is intersubjectively shared by a cultural group» (D'Andrade, 1989, s. 809). I skjemateori benyttes kulturelle skjemaer og kulturelle modeller om hverandre, altså synonymt. I denne teksten bruker jeg kulturelle modeller på de skjemaene som er delt, ellers brukes skjemaer.

Sentralt i skjemateori er begrepet «internalisering», som impliserer en prosess der det har foregått en kobling mellom verdier og avtrykk, det vil si mellom verdier og kognitive skjemaer. Ifølge Quinn et. al (2018), formulerer antropolog Drew Westen dette på en illustrerende måte: «[W]hat we mean when we say that cultural beliefs and values are 'internalized' is that they are literally built into associative networks» (i Quinn et al., 2018, s. 295). Slik Quinn et al. presenterer temaet, kan internalisering skje både gjennom repeterende erfaringer og gjennom kulturell overføring. Det sistnevnte skjer ved at personer blir eksponert for verdier, ideer, forestillinger og praksiser gjentatte ganger (Quinn et al., 2018, s. 294-304).

Noen antropologer som deler skjemateoriens syn på hvordan internalisering skjer, understreker behovet for å utvide forståelsen av hva som blir internalisert ut over tanker, emosjoner og motivasjon. De hevder at det også er viktig å ta inn kroppslige erfaringer og slik utvide skjemateori til eksplisitt å inkludere kroppsliggjøring av kultur. Det kan forstås som 
en vektlegging av internalisering gjennom repeterende erfaringer nevnt over. Begrepet «inkorporering» (Connerton, 1989) har for eksempel blitt brukt som en dypere form for internalisering. Andre begrep som anvendes, er «embodiment», «enactment», «extended mind» eller «embodied habitus» (Quinn et al., 2018, s. 295).

Forskning på kroppsliggjort kultur er imidlertid ikke noe nytt (Bourdieu, 1977). Pierre Bourdieus begrep habitus har blitt mye brukt som begrep for dette. Habitus er «[dispositions] laid down in each agent by his earliest upbringing» (Bourdieu, 1977, s. 81). Det interessante for diskusjonen i dette kapitlet er at denne forskningen viser at og hvordan tidligere erfaringer sitter i kroppen (det kognitive er også en del av kroppen) (f.eks. Bourdieu, 1977; Connerton, 1989; Killén, 1988, 2013).

Mitt selvstendige bidrag her er at disse kan kobles til kulturelle modeller og dermed utvide Bourdieus perspektiv. Internaliserte kognitive skjemaer og kulturelle modeller er en variant av Bourdieus «dispositions». Habitus er et sett av disposisjoner som bidrar til at mennesker utøver bevisste eller ubevisste handlinger (Bourdieu, 1977, s. 78). Det særegne ved skjemateori er at kulturelle modeller (disposisjoner) eksplisitt trekkes frem og begrepsfestes, noe som ikke er vanlig ved bruk av begrepet habitus. En måte å uttrykke dette på er å si at mennesker motiveres av dypt internaliserte kulturelle modeller, for eksempel om «barnets beste». Det er også av spesiell relevans for diskusjonen i dette kapitlet at dypt internaliserte kulturelle modeller, eller «embodied experience» lært over tid og gjerne implisitt, er vanskelige å endre: «the earliest learned behaviour of children, as those studied by Chapin [presenteres senere] and Sirota is likely to be not just motivating but also especially durable, reflected in its resistance to change» (Quinn et al., 2018, s. 310, min utheving). Slik sett blir det folk gjør med sine barn, hvordan de utøver foreldrerollen, og hvordan de tenker rundt hva som er barnets beste, disposisjoner i habitus - og kan være vanskelig å endre. Dette er i tråd med forskning som indikerer at foreldre har en tendens til å repetere den omsorgen de selv fikk som barn. For eksempel viser studier at voksne som har vært utsatt for omsorgssvikt eller overgrep, kan ha en tendens til å gjenta dette dersom de ikke får nok veiledning til det motsatte (Gilbert et al., 2009; Killén, 1988, 2013; Långstrøm, Babchishin, Fazel, Lichtenstein \& Frisell, 2015). Det er kjent blant 
barnevernsarbeidere, psykologer og andre at voksne som forgriper seg seksuelt på barn, ofte, men langt fra alltid, har blitt utsatt for det samme selv (Långstrøm et al., 2015). Slike forskningsresultater er gode eksempler på fortiden nedfelt i kroppen, og som kan føre til bevisste eller ubevisste handlinger.

Det at erfaringer og historie setter seg i kroppen, at kroppen «husker» noe som fører til handlinger, kan, sammen med redegjørelser av kognitive prosesser som assosiasjoner av nevrale nettverk, også forstås som et ontologisk premiss for argumentasjonen i dette kapitlet. Jeg mener at en slik tilnærming kaster et originalt lys over bekymringsmeldinger, saksfremlegg og beslutninger i barnevernet og foreldres reaksjoner på disse, og hvorfor dette kan representere spenninger. Det er fordi etisk refleksjon og beslutninger i barnevernet alltid inneholder mer eller mindre bruk av skjønn og personlig dømmekraft, slik Nordby og særlig Nordstoga diskuterer (Nordby, Bennin \& Buer, 2013, s. 298; Nordstoga, 2018). Skjønn og personlig dømmekraft er på sin side påvirket av tidligere faglige og personlige erfaringer forankret i internaliserte skjemaer i habitus. Langsrud, Fauske og Lichtwarck (2019) hevder for eksempel at barnevernsarbeidernes faktiske grunnlag - eller faktum - i et barns omsorgssituasjon, er en konstruert virkelighetsforståelse. Med andre ord viser deres studie at «faktum blir konstruert av barnevernsarbeiderne gjennom deres fortolkningsramme» (Langsrud et al., 2019, s. 3). Disse fortolkningsrammene er subjektive og kan forstås å ha utspring i habitus. Derfor blir det viktig å være oppmerksom på hvordan det subjektive og kroppsliggjorte kan spille inn i møter mellom barnevernsarbeidere og minoritetsfamilier.

Forestillingen om barnets beste er utvilsomt en kulturell modell, den er «intersubjectively shared by a cultural group» (D’Andrade, 1989, s. 809) - i dette kapitlet delt av mange ulike kulturelle grupper. Det interessante er hvordan ulike personer i helsestasjon, barnevern og andre steder forstår meningen i denne kulturelle modellen, det vil si hvilke verdier deres assosiative nettverk kan sies å bestå av. Spenninger mellom ulike kulturelle verdier mellom profesjonsutøvere og foreldre kan slik tolkes i lys av hva de ulike parter forstår som meningsinnholdet i den kulturelle modellen om «barnets beste». Fordi profesjonsutøvere og foreldre 
har ulik kunnskap, erfaring og kroppsliggjort kultur knyttet til barneomsorg og oppdragelse, har de også ulike assosiasjonsnettverk knyttet til sine kognitive skjemaer om «barnets beste». Sagt på en annen måte eksponeres de for samme uttrykk - «barnets beste» - men får ulike assosiasjoner knyttet til hva dette betyr. Slik sett kan spenninger oppstå fordi assosiasjonsnettverkene knyttet til skjemaet «barnets beste», er så ulike og kanskje også konfliktfylte. Oppdragervold, eller assosiasjonen om at barn må slås for å bli gode mennesker, er et eksempel på det siste. Dette kommer jeg tilbake til snart, men først skal jeg presentere et overordnet bakteppe for hvilke verdier særlig profesjonsutøvere i Norge, men (avhengig av botid i Norge) også familier med innvandrerbakgrunn utsettes for. Dette fordi det antas at profesjonsutøvere i Norge har internalisert disse verdiene i større eller mindre grad, og slik er de en del av deres verdigrunnlag knyttet til barnets beste. Slik kan disse verdiene i neste instans virke motiverende for hvordan profesjonsutøvere møter familier med innvandrerbakgrunn.

\section{Grunnleggende norske verdier, barnevernet og barnets beste}

Både profesjonsutøvere og familiene de møter, bor i Norge og er en del av det politiske klimaet og systemet som kalles «den norske samfunnsmodellen». Helt fra etterkrigstiden har tre overordnede grunnleggende verdier vært sentrale i den norske samfunnsmodellen: frihet, likhet og solidaritet eller fellesskap. Disse kan forstås som kulturelle modeller som er overordnet, generelle og abstrakte. Den norske arbeiderbevegelsen og Det norske Arbeiderparti har vært drivkraften i etableringen av den norske samfunnsmodellen, som i store trekk er den samme som omtales som «den nordiske modellen» (Støstad, 2015). De skandinaviske landene utmerker seg på verdensbasis angående relativt små klasseskiller grunnet en økonomisk omfordelingspolitikk, stor grad av likestilling mellom kjønn og lav arbeidsledighet. I dette politiske og verdiladede klimaet har barnevernet utviklet seg.

Som tidligere nevnt følger barnevernet i dag ofte noe som kalles «kunnskapsbasert praksis». Denne består av tre dimensjoner: 
forskningsbasert kunnskap, erfaringsbasert kunnskap og brukerkunnskap eller brukermedvirkning (Nordstoga, 2018, s. 237). Forskningsbasert kunnskap skal være basert på oppdatert forskning, men da det er mange felt relevant for barnevern, har, ifølge Nordstoga, psykologisk forskning med utviklingsteoretiske perspektiver fått forrang. Det har bidratt til at oppmerksomhet på levekår og materielle forhold kan ha blitt oversett (Nordstoga, 2018, s. 239). Fordi det ikke er mulig å være oppdatert på alle forskningsfelt, mener Nordstoga det er ekstra viktig å trekke inn de to andre dimensjonene i kunnskapsbasert praksis. Erfaringsbasert kunnskap er den kunnskapen profesjonsutøveren lærer seg gjennom praksis, både i dagligliv og i jobb, og den bygger på tidligere erfaringer både yrkesmessig og privat. Nordstoga hevder erfaringskunnskapen er noe personlig, men at det personlige skjønnet ikke blir vektlagt nok, slik erfaringsbasert kunnskap vanligvis blir forstått i begrepet «kunnskapsbasert praksis». Brukerkunnskap eller brukermedvirkning er den tredje dimensjonen, og i min sammenheng inkluderer dette spesielt familier med innvandrerbakgrunn. I kunnskapsbasert praksis skal disse lyttes til, og beslutninger skal tas i dialog med profesjonsutøvere. Disses verdier er altså sammensatt av levd liv, både privat og i yrkeslivet, og vil påvirke hvordan de forstår hva som til enhver tid er barnets beste.

Begrepet «barnets beste» og forståelsen av det har vært i bevegelse fra midten av 1950-tallet, og kan illustrere hvordan tre ulike perspektiver på barn og barndom har utviklet seg (Gjedrem, 2018, s. 63). Det første perspektivet har mest vekt på de voksne, som bestemmer barnets beste ut fra sine interesser. Det andre perspektivet har mest vekt på relasjonen mellom foreldre og barn, der barnets beste er at denne er stabil og trygg. Det siste perspektivet retter søkelyset mest på barnet, på dets rettigheter og dets kompetanse (Gjedrem, 2018, s. 63). Dette siste perspektivet reflekterer den dominerende teoretiske tilnærmingen i dagens barneforskning, der barnet er aktør og er med på å forme sin egen barndom (Corsaro, 2018).

I dette kapitlet er jeg mest opptatt av barnets beste i sosialfaglig og samfunnsfaglig sammenheng, ikke som rettslig prinsipp. Ifølge Gjedrem er sosialarbeidere spesielt opptatt av «personen og omgivelsene når hun skal forstå hva som er til barnets og familiens beste» (Gjedrem, 2018, 
s. 68). Her vil verdier om trygghet, god tilknytning mellom foreldre og barn samt gode materielle levekår spille inn, noe jeg var inne på tidligere i diskusjonen om kunnskapsbasert praksis. Jeg vil imidlertid hevde at forståelsen av «trygghet», «god tilknytning» og «gode nok materielle vilkår» vil eller kan variere kulturelt.

Innenfor familie- og sosialpolitikken, som både helsestasjon og barnevern må forholde seg til, eksisterer det i 2020 et ganske ensartet mønster for hvordan å innrede familielivet med små barn. I dag forventes det fra alle politiske partier i Norge at begge foreldre jobber, og at barna passes av andre på dagtid fra ettårsalderen. Familiepolitikken, inkludert likestillingspolitikken i den norske samfunnsmodellen, oppfordrer begge foreldre til å jobbe. Norge har gode permisjonsordninger og barnehagetilbud som bidrar til dette, der verdiene om trygghet og omsorg anses tilfredsstillende ivaretatt. De norske overordnede verdier om «likhet» og «frihet» kan også forstås å medvirke til dette kulturelle familiemønsteret («likhet» i det at «alle» bør få eller får mulighet til å velge samme mønster, «frihet» for kvinner til å velge om de vil være utenfor arbeidslivet eller ikke mens de har små barn). Men slik har det ikke alltid vært. I 1950-1960-årene var en grunnleggende verdi at kvinner ikke skulle jobbe hvis de hadde små barn, da det ble antatt at hjemmeværende mødre best ivaretok barnas behov for trygghet, tilknytning og omsorg. Dette verdisynet førte til en helt annen barndom enn det norske barn har i dag. De første sju årene av sitt liv tilbrakte barn de fleste av døgnets timer omringet av familien, først og fremst mor. I dag tilbringer barna mesteparten av sin hverdagstid sammen med profesjonsutøvere. Poenget med å trekke frem dette er å påpeke at mange av familiene fra ikke-vestlige land som helsesykepleiere og barnevernsarbeidere møter, ofte kan forstås å være motivert av den kulturelle modellen «barnets beste» som innebærer at mor skal passe barna mens de er små. En slik innstilling vanskeliggjør at innvandrerkvinner ønsker og får mulighet til lønnet arbeid (Erstad, 2015). Lønnet arbeid anses i sin tur av politikere som viktig for å få kvinner integrert og familier bort fra eventuell status som «lavinntektsfamilie», en kategori familier med innvandrerbakgrunn ofte faller innenfor (Berg et al., 2017). Oppfatninger om kvinne- og morsrollen henger tett sammen med hva som oppleves som en «god barndom», som også er en 
kulturell modell, og som er tett koblet til den kulturelle modellen om «godt foreldreskap» (Sparrman et al., 2016).

Fokus på barn og barndommens innhold hevdes å være spesielt utbredt i Norge og andre skandinaviske land (Gullestad, 1996). Hva som er en «god barndom», er verdiladet og kulturspesifikt, koblet til forestillingen om «godt foreldreskap» (Sparrman et al., 2016) og «god nok omsorg». I Norge forbindes en god barndom gjerne med verdier som trygge omsorgspersoner, akseptabel materiell levestandard, mye lek og deltakelse i organiserte fritidsaktiviteter (Rysst, 2008). Ifølge antropolog Marianne Gullestad er barn sentrale i norsk nasjonalsymbolisme, indikert blant annet med at barn går i tog på nasjonaldagen 17. mai, ikke soldater (Gullestad, 1996).

Nyankomne flyktninger kan ha en annen forståelse av og andre verdier for hva som er barnets beste og gode oppvekstforhold. For familier som flykter fra krig, kan det være så enkelt som at en god oppvekst er fravær av krig. Folk fra ikke-vestlige land kan også ha lavere forventninger til hva som er gode nok materielle forhold for barn å vokse opp i. De kan ha tilbrakt mange år på flukt eller i flyktningleir og stiller mindre krav til materiell levestandard enn fagfolk i barneverntjenesten og i Norge generelt. De kan også komme fra enkle materielle kår i hjemlandet, for eksempel i Somalia. Tall fra Statistisk sentralbyrå viser at det er hushold med såkalt lav inntekt som utgjør majoriteten av alle familier med tiltak i barnevernet (Berg et al., 2017), og at familier med innvandrerbakgrunn utgjør en stor del av disse. Med andre ord er det en tydelig sammenheng mellom innvandrerbakgrunn, lav inntekt og hjelpetiltak i barnevernet. Den norske forståelsen av hva en god barndom er, antas å være en del av de verdiene barnevernet navigerer etter, og materielle levekår kan være noen av disse, selv om Nordstoga mener at utviklingspsykologiske verdier har dominert over disse (Nordstoga, 2018). Likevel kan vi trolig si at i norske profesjonsutøveres habitus finnes det likeartede kombinasjoner og assosiasjonsnettverk av norske verdier for en god barndom, mens for nyankomne flyktninger er det verdier og erfaringer fra hjemlandet som preger deres habitus. Dette kan også være tilfellet i familier med innvandrerbakgrunn generelt, uavhengig av botid i Norge. 
I neste underkapittel skal jeg svare mer eksplisitt på problemstillingen jeg stilte tidligere, nemlig: Hvordan kan eventuelle spenninger i møtet mellom profesjonsutøvere i barneomsorg og foreldre forstås med fokus på kulturelle verdier knyttet til «barnets beste»?

\section{Spenningsforhold mellom profesjonsutøveres og foreldres verdier angående barnets beste}

En første måte å nærme seg forståelse av verdigrunnlaget til profesjonsutøvere i helsestasjon og barnevern på kan være å ta utgangspunkt i det Nordby omtaler som samfunnsverdier, personlige verdier og kulturelle verdier (Nordby et al., 2013, s. 262-298), mens neste skritt blir videreføring til internaliserte kulturelle modeller og kroppsliggjort kultur. Nordbys «samfunnsverdier» er "generelle idealer som frihet, likhet og mer spesifikt barns rett til å leve under trygge, beskyttende og utviklende oppvekstsvilkår» (Nordby et al., 2013, s. 262). Disse verdiene er i overensstemmelse med det som tidligere ble omtalt som «grunnleggende norske verdier». Videre nevner Nordby «personlige verdier», som er subjektive preferanser av prioriterte aktiviteter, mens «kulturelle verdier» plasseres «mellom disse verdibegrepene». Kulturelle verdier er sosial kapital forstått som aktiviteter og livssyn forankret i et sosialt fellesskap som individer identifiserer seg mer eller mindre med (Nordby et al., 2013, s. 262).

I lys av skjemateori kan Nordbys «kulturelle verdier» forstås som overordnede, generelle, men upresise kulturelle modeller, som bør tydeliggjøres for å si at de virker motiverende for noens handlinger. En presisering av hva slags livssyn det er snakk om, kan være «mor bør være hjemme med et barn til det er tre år gammelt». Dette utgjør en kulturell modell som motiverer omsorgspraksis. Profesjonsutøverne i barnevernet navigerer, som alle mennesker, etter en kombinasjon av både samfunnsverdier, personlige verdier og kulturelle verdier, men først og fremst motiveres de av bevisste eller ubevisste kulturelle modeller, det vil si assosiasjonsnettverk, av hva «barnets beste» betyr og innebærer. For noen profesjonsarbeidere inkluderer assosiasjonsnettverket i den kulturelle modellen «barnets beste» verdien om at barn må ha tydelige grenser og en tilfredsstillende materiell levestandard, mens for andre profesjonsarbeidere kan 
dette assosiasjonsnettverket inneholde mer fleksibilitet og frihet når det gjelder grensesetting, enkel standard, arv og gjenbruk. Med andre ord: Profesjonsarbeideres personlige skjønn og dømmekraft kan eller vil variere i saker som dette. Imidlertid motiveres også foreldre, uavhengig av etnisk bakgrunn, bevisst eller ubevisst, av en kulturell modell om barnets beste, der ulik holdning til omsorgspraksis, materiell levestandard og grensesetting utgjør viktige deler av assosiasjonsnettverket.

En god illustrasjon på hvordan møter mellom profesjonsutøveres internaliserte verdier om barn og omsorg og innvandrerkvinners sådanne, kan forstås å komme til syne i datamaterialet til Erstads doktorgradsarbeid om norsk-pakistanske mødres oppdragelse av sine barn. Erstad skriver riktignok ikke om barnevernet, og hun anvender ikke perspektiver fra psykologisk antropologi. Hennes materiale får likevel godt frem ulik tenkning og dermed det jeg tolker som kulturelle modeller om «god omsorg» og barnets beste blant norsk-pakistanske kvinner med ulik botid i Norge, og helsepersonell eller barnehagelærere som de møter i Alna bydel i Oslo. Relevansen for å trekke inn dette her er at det kan være på slike arenaer spenninger i møter mellom profesjonsutøvere og foreldre kan oppstå, og der bekymringsmeldinger blir sendt til barnevernet. La oss derfor ta en tur til Alna bydel og «høre» hvordan norsk-pakistanske mødre opplever møter med hvordan de «skal oppdra barn i Norge» (Erstad, 2015, s. 174).

Erstads avhandling inkluderer 30 mødre mellom 20 og 30 år med pakistansk bakgrunn, 17 av disse er født og oppvokst i Norge. Erstad møtte disse i bydelens ulike tilbud til mødre med små barn, der særlig to «familiehus» var sentrale. Disse hadde tilbud om åpen barnehage, helsestasjon, svangerskapsomsorg og et fagsenter for barn og unge. Av særlig interesse for dette kapitlet er bydelens tilbud om et kurs over tolv uker, kalt International Child Development Program (ICDP). Der ble det tydeliggjort hva som var likt og forskjellig mellom to sosialiseringsmodeller, en norsk og en pakistansk. Grunnene som ble gitt for å delta på kurset, var å utvikle egne foreldreferdigheter og «å lære hvordan man oppdrar barn i Norge» (Erstad, 2015, s. 174).

Mødrene blir oppfordret til å «velge» mellom de to sosialiseringsmodellene, men ifølge Erstad opplever mødrene implisitt at den norske blir fremstilt som «best»(Erstad, 2015). Helt konkret blir mødrene vist detaljer 
i to (stereotype) sosialiseringsmodeller, en norsk og en pakistansk, fremstilt som to trekanter, der den pakistanske står med spissen opp, den norske med spissen ned. Dette skal symbolisere at små barn (frem til tolv års alder) får få grenser i den pakistanske, mens i den norske er det grensesetting fra fødselen av, med gradvis mer frihet. I den pakistanske modellen er det omvendt, med mindre frihet dess eldre barnet blir, særlig for jenter. En slik fremstilling av hovedforskjeller mellom norsk og ikke-vestlig barneomsorg, her pakistansk, i form av trekanter og mye frihet for de minste barna hos de ikke-norske, er også kjent fra andre steder i Norge (Smette \& Rosten, 2019). I tråd med dette forteller for eksempel en barnevernsarbeider et annet sted i Norge enn Alna om hvordan barn hun møter, oppdras etter andre kulturelle verdier enn dem hun er vant til:

Og så sånne afrikanske land, de er jo ofte helt motsatt av sånn vi gjør i Norge.

Da får jo små barn bare løpe rundt som de vil, og så får de masse ansvar når de blir 10-12 år. Så det er jeg nødt til å ta høyde for. (Tuastad, Handulle \& Alfonso, 2017, s. 135)

Med andre ord ser det ut til at denne profesjonsarbeideren reagerer på at «barna får løpe rundt som de vil», implisitt uten grensesetting, og at dette ikke er slik barn oppdras i Norge. Det kan indikere at hennes kulturelle verdier om barneomsorg står i motsetning til verdier i afrikanske land, og at disse er noen hun har internalisert gjennom eget dagligliv og kunnskapsbasert praksis (Nordstoga, 2018).

Inntrykket av at profesjonsarbeidere i møte med mødrene i Alna bydel mer eller mindre direkte viser at de mener den norske modellens verdier burde velges av mødrene, kommer frem i en «lekse»-besvarelse fra en av mødrene. Hun skriver (Erstad, 2015, s. 189):

Jeg prøver å oppdra mine barn i tråd med norsk kultur. Barneoppdragelse i Norge og i mitt hjemland er veldig forskjellig. Mange ting er ikke likt.

1) Norske setter grenser for sine barn når de er små.

2) Vold og plaging er ikke lov i norsk kultur.

3) Begge foreldre har ansvar for barna. Hvis, for eksempel, mor jobber tidlig og far har sent skift, er faren ansvarlig for å få barna i barnehagen eller skolen. Eller til legen eller hva det måtte være. 
4) Hvis barna ikke hører på, snakker foreldrene til barna. Null stress.

5) I Norge blir gutter og jenter oppdratt likt.

Her ser vi hvordan denne moren har forstått hvilket budskap som ligger i kurset, der mødrene opplever en oppfordring til å innta verdiene $\mathrm{i}$ den norske varianten, jamfør det hun skriver om at «jeg prøver å oppdra mine barn i tråd med norsk kultur», med andre ord norske «verdier». Hvis det er slik som Quinn et al. hevder (Quinn et al., 2018, s. 310), at dypt internaliserte eller kroppsliggjorte skjemaer er vanskelige å endre, er det ikke bare å «bestemme seg for» å endre praksis over natten. I lys av psykologisk antropologi kan mange norsk-pakistanske mødre forstås som at de har internalisert den pakistanske modellen, og de finner det derfor vanskelig å «kvitte seg med» verdiene eller assosiasjonsnettverkene i denne og ta inn den norske modellen eller verdiene (Bourdieu, 1977; Quinn et al., 2018, s. 310). Som en av de norsk-pakistanske mødrene sa: «Mødre gjør som bestemor har gjort før henne, er det ikke sånn, men her [på kurset] blir vi vist mange alternativer» (Erstad, 2015, s. 180). Derfor vil noen antakelig gjøre et forsøk, noe Erstad viser. Kan dette kurset slik sett tolkes som etnosentrisk? Hvorfor er for eksempel den norske modellen eller verdiene med tidlig grensesetting «bedre» enn modellen uten?

Antropolog Bambi L. Chapin (2018) skriver om en lignende sosialiseringsmodell på Sri Lanka, en modell hun kaller «hierarkiseringsmodellen». Sammenlignet med det hun kjente fra middelklasse-USA, medførte denne modellen eller disse verdiene at små barn fremsto som svært krevende, og at de fikk viljen sin umiddelbart. I denne sosialiseringsmodellen lærte barn fra de var små at de voksne bestemte (hierarki), men ville barnas beste, og tanken var at barn lærte gjennom å få viljen sin fra de var små, og gjennom reaksjoner på sin adferd fra omgivelsene. Oppdragelsen lå i at når barnet krevde og fikk noe som var sosialt lite akseptabelt, for eksempel å spytte mat på gulvet, fikk barnet negativ respons. Dette medførte at barnet ikke krevde det samme en gang til, og at større barn fremsto som svært veloppdragne og lydhøre sammenlignet med amerikanske barn (Chapin, 2018). En slik måte - eller slike verdier som grunnlag for å tenke «barnets beste» på - er mer i tråd med de norsk-pakistanske mødrenes og avviker fra det som er mest vanlig i Norge. Kan det her ligge spirer for bekymringsmelding til barnevernet, ved at små barn som tolkes 
som krevende, uregjerlige, ulydige, forstås som at de har atferdsvansker på grunn av mulig omsorgssvikt? Det er mitt inntrykk at det eksisterer en oppfatning i Norge om at små barn må få tydelige grenser (Strømøy, 2015), ellers blir de fort uoppdragne og «ville». Kan mor meldes som en mulig «dårlig» mor fordi barna tolkes som uregjerlige, særlig i kombinasjon med andre kriterier for omsorgssvikt, som for eksempel arbeidsløshet, dårlige klær eller lav boligstandard? I så fall er det jo ulik forståelse av barnets beste, det vil si ulike kulturelle verdier, og ikke «omsorgssvikt» denne (fiktive) familien viser. For de pakistanske mødrene og mødrene fra Sri Lanka forstås jo barnets beste som at barn skal ha det mest mulig fritt de første årene, mens blant mange norske foreldre og helsesykepleiere forstås barnets beste blant annet som bestående av regelmessighet, rutiner og gode vaner (Rysst Heilmann, 2000; Erstad, 2015).

Poenget med disse eksemplene fra norsk-pakistanske mødre, tenkningen på Sri Lanka og glimt fra norsk barnevern er å vise hvordan ulik kroppsliggjort kultur og internalisering av kulturelle modeller eller verdier om barnets beste, morsroller, god barndom og familieliv kan forstås som utgangspunkt for spenninger i møter mellom profesjonsutøveres og foreldres (mødres) verdier. Med andre ord viser eksemplene hvordan kulturelle forventninger til hvordan små barn skal oppføre seg, varierer. Disposisjonene i habitus eller kroppsliggjort kultur er ofte ubevisste, og som nevnt over er de da ifølge Quinn et al. (2018) vanskelige å endre fordi de sitter «dypt» i oss. De norsk-pakistanske kvinnene i Erstads materiale prøver i varierende grad å ta til seg de norske verdiene om «riktig» barneomsorg, men finner det vanskelig og i strid med nedfelt overbevisning. Noe lignende kom også frem i en studie referert av Tuastad, Handulle og Alfonso (2017), der en mor i kontakt med barnevernet sier:

[...] da sa jeg hva med å respektere min religion? Det som er motstridende mot min religion, og det jeg ønsker mine barn skal vokse opp med, er opp til meg, det har ikke dere noe med å gjøre. Og da svarte de: helt til dere frivillig ønsker å integrere deres barn i det norske samfunnet, så kommer vi alltids til å være til stede. Det er så ovenfra og ned, det er totalt nedverdigende. (Tuastad et al., 2017, s. 135)

Denne moren opplevde også, som de norsk-pakistanske mødrene over, at egne verdier og egen forståelse av barnets beste ble overkjørt av 
profesjonsarbeidere i barnevernet eller helsestasjonen. Det opplevde også denne moren fra Polen:

Under oppfølgingsmøter, så sa jeg dere vet nå at jeg ikke slår mine barn, dere har ingen bevis, jeg ville aldri gjort det. Så hva er grunnen til at vi skal fortsette med disse møtene? Og da svarte de: helt til du lar barna få så mye fritid og lar dem delta på bursdager og slike ting. (Tuastad et al., 2017, s. 134)

Ut fra alle disse eksemplene kan disse spenningene forstås som resultat av ulike forståelser av barnets beste, fra internaliserte kulturelle modeller i habitus. Det er god grunn til å spørre om ikke eksemplene også utviser en etnosentrisk innstilling til immigrantfamiliers verdier og forståelse av barnets beste. Dette forholder seg mer forståelig når vold er med i oppdragelsen, noe som jo er forbudt i Norge. Som nevnt tidligere inngår bruk av vold som disiplinering i noen innvandrerfamiliers barneoppdragelse. Derfor er problemer med såkalt oppdragervold et gjentakende tema i norsk barnevern. En mor fra et land i Afrika sier:

De siste årene med disse nye flyktningene så ser jeg at det er mer og mer sånn fysisk avstraffelse. Det er fordi de kommer fra landsbyer og har litt hardere vei for å komme til Norge. De har opplevd veldig mye på vei, de har mye frustrasjoner, mye som har gått galt i Norge. Jeg kjenner mange som ikke ønsker å gjøre det men de gjør det, de har ikke noen annen måte. Masse forskjellige ting. Og barna blir tatt fra dem og sånne ting. (Smette \& Rosten, 2019, s. 37)

I deres assosiasjonsnettverk i den kulturelle modellen «barnets beste» inngår muligheten for å bruke vold, og dette kan sitte dypt. De ønsker ikke å slå, men gjør det likevel. Dette kommer bedre frem i dette sitatet fra den samme moren:

Hos oss har det ikke vært så mye, det er mer sitte i 5 minutter om du har gjort noe galt. Men det har vært veldig sjelden [vold]. Men det har hendt at, når de var mindre, da. At jeg har fått den der ... Det er litt flaut å si det, men av og til så har du sånne ting som sitter, ikke sant. At barn gjør det. «Ikke gjør sånn!» [illustrerer klask med hånda]. Ikke sant. Men det er sånn. (Smette \& Rosten, 2019, s. 38) 
Her kan morens utsagn «at jeg har fått den der ...» tolkes som en god illustrasjon av fenomenet med kroppsliggjort kultur, at handlinger kan motiveres av noe ubevisst som bare kommer som en slags «trang». Og det er denne «trangen» til å handle på bestemte måter som angår både profesjonsarbeidere i Norge og familier med både norsk og utenlandsk bakgrunn, og som viser hvordan verdier i internaliserte kulturelle modeller kan komme til overflaten.

\section{Konklusjon}

Sitatet innledningsvis pekte på at det er profesjonsarbeidere som definerer hva som er omsorgssvikt, hva som er uforsvarlig omsorg, og hva som er skadelig for barn basert på sin forståelse av barnets beste. I dette kapitlet har jeg diskutert hvordan perspektiver fra psykologisk antropologi kan gi en annerledes innsikt $\mathrm{i}$ hvordan og hvorfor variasjoner i kulturelle forståelser av barnets beste og spenninger oppstår. Jeg har vist hvordan et slikt perspektiv kan kaste lys over hvordan spenninger i møter mellom profesjonsutøvere og foreldre med immigrantbakgrunn kan forstås - at ulike verdier i internaliserte kulturelle modeller samt kroppslige erfaringer om barnets beste motiverer til ulik handling og forståelse. Verdier knyttet til barneomsorg og foreldreomsorg internaliseres eller inkorporeres gjennom repeterende erfaring og kulturelle overføringer og setter seg i habitus som ubevisste og bevisste disposisjoner for handling. Min analyse styrker Nordstogas argument om at vi bør ha større oppmerksomhet på betydningen av personlige, erfaringsbaserte verdiers innflytelse i møter mellom profesjonsutøvere og familier (Nordstoga, 2018). Men i motsetning til Nordstoga har min analyse heller fått frem mulige negative konsekvenser av dette, enn positive. Jeg har foreslått at skjemateori og teori om kroppsliggjort kultur er en måte å få frem hvordan personlige erfaringer, skjønn og dømmekraft kan påvirke beslutninger om barnets beste i barnevernet.

I kapitlet presenteres flere spørsmål enn svar. Det har blant annet blitt spurt om profesjonsutøveres holdninger kan tolkes som etnosentriske, fordi norske verdier mer eller mindre fremstilles som «bedre» enn de verdier immigrantfamiliene har. Mødre med immigrantbakgrunn motiveres 
ofte av sine kulturelle modeller om barnets beste og om godt moderskap fra sitt opprinnelsesland, modeller som er dypt inkorporert, men ikke umulige å endre over tid. Det kan derfor også spørres om endring er nødvendig for å oppdra harmoniske barn i et nytt hjemland.

\section{Litteratur}

Aarset. M. F. \& Bredal, A. (2018). Omsorgsovertakelser og etniske minoriteter. (NOVA rapport 5/18). Hentet fra http://flyktning.helsekompetanse.no/sites/flyktning. helsekompetanse.no/files/Omsorgsovertakelser_og_etniske_minoriteter_En_ gjennomgang_av_saker_i_fylk.PDF

Berg, B., Paulsen, V., Midjo, T., Haugen, G. M. D., Garvik, M. \& Tøssebro, J. (2017). Myter og realiteter. Innvandreres møter med barnevernet. Trondheim: NTNU Samfunnsforskning.

Bloch, M. (1992). What goes without saying: The conceptualization of Zafimaniry society. I A. Kuper (Red.), Conceptualizing society. London, England: Routledge.

Bourdieu, P. (1977). Outline of a theory of practice. Cambridge, England: Cambridge University Press.

Bufdir. (2019a). Melde fra til barnevernet - offentlig ansatt. Hentet 23. oktober 2019 fra https://www.bufdir.no/Barnevern/Melde_fra_til_barnevernet/Melde_fra_til_ barnevernet_offentlig_ansatt/

Bufdir, (2019b). Utredning av kompetansehevingstiltak i barnevernet. (Rapport 04/2019). Hentet fra https://bufdir.no/globalassets/bufdirs-kompetanseutredningendelig.pdf

Chapin, B. L. (2018). Learning about culture from children: Lessons from rural Sri Lanka. I N. Quinn (Red.), Advances in culture theory from psychological anthropology (kap. 7). New York: Palgrave Macmillan.

Christiansen, Ø. \& Kojan, B. H. (red.). (2016). Beslutninger i barnevernet. Oslo: Universitetsforlaget.

Connerton, P. (1989). How societies remember. Cambridge, England: Cambridge University Press.

Corsaro, W. A. (2018). The sociology of childhood. Los Angeles, CA: Sage Publications.

Csordas, T. (1990). Embodiment as a paradigm for anthropology. Ethos, 18(1), 5-47.

D’Andrade, R. G. (1989). Cultural cognition. I M. I. Posner (Red.), Foundations of cognitive science. Cambridge: MIT Press.

D’Andrade, R. G. \& Strauss, C. (1992). Human motives and cultural models. Cambridge, England: Cambridge University Press.

D’Andrade, R. G. (2008). A Study of personal and cultural values. New York: Palgrave Macmillan. 
De forente nasjoner. (1989). FNs konvensjon om barnets rettigheter. Hentet fra https://www.regjeringen.no

Erstad, I. (2015). Here, now and into the future: Child-rearing among NorwegianPakistani mothers in a diverse borough in Oslo, Norway (Doktoravhandling). Universitetet i Oslo, Oslo.

Fylkesnes, M. K., Iversen, A. C., Bjørknes, R. \& Nygren, L. (2015). Frykten for barnevernet - en undersøkelse av etniske minoritetsforeldres oppfatninger. Tidsskriftet Norges Barnevern, 92(2).

Gilbert, R., Widom, C. S., Browne, K., Fergusson, D., Webb, E. \& Janson, S. (2009). Burden and consequences of child maltreatment in high-income countries. Lancet, 373(9657), 68-81.

Gjedrem, J. (2018). Barnets beste. I T. A. Ask \& S. B. Eide (Red.), Barnevernets begreper - $i$ bevegelse (s. 63-78). Oslo: Gyldendal.

Gullestad, M. (1996). Imagined childhoods. Oslo: Universitetsforlaget.

Heggen, K. \& Dahl, S. L. (2017). Barnevernets kunnskapsgrunnlag. Fontene forskning $10(1), 70-83$.

Killén, K. (1988). Omsorgssvikt og barnemishandling. Oslo: Kommuneforlaget.

Killén, K. (2013). Barndommen varer i generasjoner (3. utg.). Oslo: Kommuneforlaget.

Kojan, B. H. (2010). «Underdog»? Barnevernarbeideres erfaringer fra å møte høystatusfamilier. Fontene forskning, 2, 50-61.

Kronenfeld, D. B. (1996). Plastic glasses and church fathers. New York: Oxford University Press.

Langsrud, E., Fauske, H. \& Lichtwarck, W. (2019). Den barnevernskapte virkelighet: et sosialkonstruktivistisk perspektiv på det faktisk grunnlaget i barnevernets beslutninger. Tidsskrift for velferdsforskning, 22(1), 74-89.

Læret, O. K. \& Skivenes, M. (2016). Kvalitet og legitimitet i barnevernets beslutninger. I Ø. Christiansen \& B. H. Kojan (Red.), Beslutninger i barnevernet (s. 34-47). Oslo: Universitetsforlaget.

Långstrøm, N., Babchishin, K. M., Fazel, S., Lichtenstein, P. \& Frisell, T. (2015). Sexual offending runs in families: A 37-year nationwide study. International Journal of Epistemology, 44(2), 713-720.

Nordby, H., Bennin, C. \& Buer, B. A. (2013). Etikk i barnevern. Oslo: Gyldendal Akademisk.

Nordstoga, S. (2018). Kunnskapsbasert praksis. I T. A. Ask \& S. B. Eide (Red.), Barnevernets begreper - $i$ bevegelse (s. 233-250). Oslo: Gyldendal.

NOU 2012: 5. (2012). Bedre beskyttelse av barns utvikling. Ekspertutvalgets utredning om det biologiske prinsipp i barnevernet. Hentet fra https://www.regjeringen.no/ no/dokumenter/nou-2012-5/id67140o/ 
NOU 2016: 16. (2016). Ny barnevernslov. Sikring av barnets rett til omsorg og beskyttelse. Hentet fra https://www.regjeringen.no/no/dokumenter/nou-2016-16/ id2512881/

NOU 2017: 12. (2017). Svikt og svik. Gjennomgang av saker hvor barn har voert utsatt for vold, seksuelle overgrep og omsorgssvikt. Hentet fra https://www.regjeringen. no/no/dokumenter/nou-2017-12/id2558211/

Quinn, N., Sirota, K. G. \& Stromberg, P. G. (2018). Conclusion: Some advances in culture theory. I N. Quinn (Red.), Advances in culture theory from psychological anthropology (s. 285-327). New York: Palgrave Macmillan.

Quinn, N. (2018). Advances in culture theory from psychological anthropology. New York: Palgrave Macmillan.

Rysst Heilmann, M. (2000). Alle sier forskjellig. Innhold, overføring og endring av kunnskap og tradisjon i barneomsorgspraksis (Hovedfagsoppgave). Universitetet i Oslo, Oslo.

Rysst, M. (2008). I want to be me. I want to be kul (Doktoravhandling). Universitetet i Oslo, Oslo.

Shore, B. (1996). Culture in mind. Oxford: Oxford University Press.

Sparrman, A., Westerling, A., Lind, J. \& Dannesboe, K. I. (2016). Doing good parenthood. Ideals and practices of parental involvement. Basingstoke, England: Palgrave Macmillan.

Spiro, M. E. (1997). Gender, ideology and psychological reality. London, England: New Yale Press.

Smette, I. \& Rosten, M. (2019). Et iakttatt foreldreskap. Om å være foreldre og minoritet i Norge (NOVA rapport 3/19). Oslo: Norsk institutt for forskning om oppvekst, velferd og aldring.

Strauss, C. \& Quinn, N. (1997). A cognitive theory of cultural meaning. Cambridge, England: Cambridge University Press.

Strømøy, T. (2015). Oppdragelse mellom frihet og grenser. Oslo: Cappelen Damm Akademisk.

Studsrød, I. \& Tuastad, S. E. (2017). Barneomsorg på norsk. I samspill og spenning mellom hjem og stat. Oslo: Universitetsforlaget.

Støstad, J. E. (2015). Den norske modellen på 1-2-3. Oslo: Studieforbundet AOF Norge.

Tuastad, S. E., Handulle, A. A. M. \& Alfonso, N. P. (2017). Etnosentrisk barnevern?. I I. Studsrød \& S. E. Tuastad (Red.), Barneomsorg på norsk. Oslo: Universitetsforlaget. 



\title{
Spenningsforhold mellom beskyttelse og medvirkning i forskning på familieråd
}

\section{Lene Nygaard Solli}

Stipendiat, Barns og unges deltakelse og kompetanseutvikling, Høgskolen i Innlandet

\begin{abstract}
In this chapter I discuss research on Family Group Conferences (FGC). The aim is to discuss whether the research recognises the tension between two core values in child protection work: protection and participation. The research is divided into three categories: research on effect, research on experiences, and research on power. Research on effect is based on ambitious outcome goals concerning protection. Research on people's experiences with FGC contributes with a more nuanced and optimistic evaluation of the model. However, this research does not address power relations involved in the process. Research on power in FGC has a critical perspective and demonstrates how the process can conceal power relations. Even though these contributions shed light on important issues, I argue for the need to include a perspective on power as relational and productive. I consider Foucault's contribution to the study of power in modern Western societies as a valuable approach.
\end{abstract}

Keywords: family group conference, participation, protection, research, child protection, power

\section{Innledning}

Beskyttelse og medvirkning er to kjerneverdier i barnevernets arbeid. Barns rett til beskyttelse handler om en erkjennelse av at barnet er sårbart og trenger vern mot voksenverdenen, slik at det ikke lider psykisk 
og fysisk overlast (Qvortrup, 2010). Medvirkning, slik det blir forstått i denne teksten, handler om situasjoner der barn og familier som er i kontakt med barnevernet, har innflytelse over beslutningene (jf. Arnstein, 1969; Hart, 1992). Medvirkning er dermed ikke det samme som tilstedeværelse, men handler om at meningene man uttrykker, har innvirkning på beslutningene (Paulsen \& Studsrød, 2019). Når barnevernet gjør bruk av beslutningsmodellen familieråd, er dette et forsøk på å forene barnets rett til beskyttelse med prinsippet om medvirkning. I et familieråd samles barnets familie og nettverk for å lage en plan for barnets omsorgssituasjon. Ved å legge til rette for medvirkning er tanken at man gir barn og familier større innflytelse over beslutningene, mobiliserer ressurser rundt barnet og samarbeider for barnets beste. Modellen har blitt møtt med entusiasme og er i tråd med ønsket fagutvikling i barnevernet (Saus, Jenssen \& Strandbu, 2017). Til tross for dette blir modellen brukt i mindre grad enn det entusiasmen skulle tilsi. Det kan være mange årsaker til dette, for eksempel strukturelle rammebetingelser i barnevernet (Saus et al., 2017).

I dette kapitlet tar jeg utgangspunkt i foreliggende forskning om familieråd, og jeg drøfter i hvilken grad denne forskningen belyser og anerkjenner spenningsforholdet mellom verdiene beskyttelse og medvirkning i barnevernet. Et premiss for diskusjonen er at det er et spenningsforhold mellom disse to kjerneverdiene i barnevernets arbeid. Dette kan forklares med nye endringer i barnevernloven (1.juli 2018), som nå gir barnet en rett til å medvirke i forhold som vedrører barnet (jf. barnevernloven [bvl.], 1992, \$ 1-6). Barnevernet har også en plikt til å samarbeide med foreldre så langt som mulig (jf. bvl., 1992, \$ 1-7). Samtidig er det forventet av samfunnet og forankret i loven at barnevernet skal sikre at barn og unge som er utsatt for skadelige oppvekstvilkår, får den hjelpen, omsorgen og beskyttelsen de trenger (jf. bvl., 1992, \$1-1). For at barnevernet skal kunne utøve sitt mandat om å beskytte barn, er det derfor nødvendig at de gjør vurderinger og arbeider ut fra et minimumskrav om hva som er en god nok omsorgssituasjon (Healy, 1998).

Spenningsforholdet kommer til uttrykk i motsetningen mellom barnevernets kontrollfunksjon på den ene siden og barnevernets oppgave om å støtte foreldre i deres omsorgsoppgaver på den andre siden. De 
som jobber i barnevernet, må balansere mellom maktutøvelse og medvirkning i det praktiske arbeidet. I familieråd blir spenningsforholdet mellom disse vilkårene spesielt fremtredende. Modellen forutsetter at de profesjonelle retter oppmerksomheten mot ressursene i familie og nettverk fremfor mot utfordringer. De må ha tillit til at familierådet kommer frem til gode løsninger. Samtidig må de forsikre seg om at barnet blir ivaretatt. Det medfører at de må uttrykke sine bekymringer og i noen tilfeller sette begrensninger for familiens handlingsrom.

Selv om jeg i kapitlet vil peke på noen resultater fra forskning om familieråd, må ikke teksten leses som en kunnskapsgjennomgang av foreliggende forskning. Jeg har delt forskning om familieråd i tre kategorier: effektforskning, forskning om erfaringer og forskning om makt. Målet med kapitlet er todelt. Først vil jeg undersøke i hvilken grad foreliggende forskning om familieråd belyser og anerkjenner spenningsforholdet mellom beskyttelse og medvirkning. Deretter vil jeg skissere en tilnærming til forskning på familieråd som er inspirert av Foucaults maktforståelse, og jeg vil diskutere hvordan dette perspektivet kan bidra til å anerkjenne spenningsforholdet mellom beskyttelse og medvirkning i barnevernet.

Et underliggende poeng i kapitlet er at dersom forskningen skal være nyttig for praksisfeltet og komme brukerne til gode, er det viktig at forskningen anerkjenner de faktiske vilkårene og kompleksiteten som preger barnevernets arbeid. Det er dessuten grunn til å forvente økt bruk av familieråd i årene som kommer. Barnevernet har nå en plikt til å jobbe systematisk med å legge til rette for nettverksinvolvering når man skal finne fosterhjem til et barn (bvl., 1992, $\$$ 4-22 tredje ledd). Familieråd er en metode som kan egne seg godt for dette.

I kapitlet vil jeg først gi et innblikk i noen sentrale kjennetegn ved familierådmodellen og dilemmaer som kan oppstå i spenningsforholdet mellom beskyttelse og medvirkning. Videre følger analysen av forskningslitteraturen, før Foucaults maktbegrep introduseres og diskuteres.

\section{Bakgrunn}

For å arrangere et familieråd engasjerer barneverntjenesten en uavhengig koordinator. Koordinatoren er ansatt i Bufetats ulike regioner, som har 
ansvar for det statlige barne- og familievernet. Noen få kommuner har egne koordinatorer, men det er et poeng at koordinatoren ikke er ansatt i barnevernet eller har kjennskap til familien fra før. I forkant av familierådet samarbeider barnevernet og familien om å utarbeide konkrete spørsmål familierådet skal svare på. Modellen kjennetegnes ved at utvidet familie deltar på møtet, og ved at familien får avsatt tid til å diskutere alene, uten at koordinatoren eller profesjonelle er til stede. Familieråd er en arbeidsmetode som egner seg godt for å finne ut om barnet har slektninger eller andre i nettverket som kan bistå med omsorgsoppgaver. Et viktig prinsipp i modellen er at planen familien kommer frem til, skal godkjennes av barnevernet så lenge barnets sikkerhet er ivaretatt. I løpet av de siste ti-femten årene har det vært økt oppmerksomhet omkring barneperspektivet i familieråd. Det går ut på at man skal legge til rette for at barnet blir ivaretatt og lyttet til (Strandbu, 2007). Modellen skal altså bidra til å nedtone den profesjonelles makt i beslutningsprosessen. Familieråd bygger på demokratiske prinsipper, som retten til å bli hørt, retten til å bestemme over eget liv og maktutjevning.

Utgangspunktet for diskusjonen i dette kapitlet er spenningsforholdet mellom å ivareta barnets rett til beskyttelse og å legge til rette for medvirkning fra barnet og barnets familie. Dette kan ses i lys av to til dels motstridende utviklingslinjer i sosialt arbeid. På den ene siden handler det om krav om at arbeidet skal baseres på humanistiske og demokratiske verdier, der medvirkning og myndiggjøring står sentralt. På den andre siden finner vi samfunnsmessige og organisatoriske endringer som har ført til økt krav om evidens, målbarhet og effektivitet (Natland \& Malmberg-Heimonen, 2016, s. 45). Som jeg var inne på innledningsvis, får ansatte i velferdstjenestene det som beskrives som en dobbeltrolle. De skal være hjelpere som ivaretar borgernes autonomi, og eksperter som skal kontrollere borgerne (Järvinen \& Mik-Meyer, 2012, s. 13). I barnevernet kan dette komme til utrykk i forventninger om at barnevernet skal anerkjenne familiers forskjellige livspraksiser og rett til innflytelse over beslutninger som gjelder deres eget liv. Samtidig skal arbeidet være kunnskapsbasert, og det skal vurderes ut fra om tjenesten faktisk bidrar til å oppfylle målet om å beskytte barn og unge mot negative oppvekstsvilkår. 
At det offentlige har ansvar for å beskytte barn og unge mot negative oppvekstsvilkår, og at dette arbeidet baseres på demokratiske verdier, som retten til innflytelse over eget liv, er samfunnsverdier de fleste er enige om (jf. kap. 1). Verdiene behøver ikke å være motstridende. Familieråd er et eksempel på en praksis der man forsøker å jobbe mot målet om beskyttelse samtidig som barnet og familien medvirker i prosessen. Dilemmaer kan likevel oppstå i konkret arbeid med barn og familier, og verdiene må veies mot hverandre. I hver enkelt sak må barnevernarbeideren bruke verdiladet skjønn for å vurdere hva som er riktig å gjøre. Det kan være vurderinger om hvor aktive de som fagpersoner skal være i formuleringen av spørsmålene til familierådet, eller om de skal godkjenne planen barnet og familien har kommet frem til. Økt oppmerksomhet om medvirkning skal ikke gå på bekostning av å tilby barn og unge den beskyttelsen de har rett på. Samtidig skal ikke oppmerksomheten på beskyttelse gå på bekostning av konstruktive medvirkningsprosesser. Det er med andre ord en hårfin balansegang mellom verdiene, og selv om familierådmodellen er en manualbasert modell, har verdibasert skjønn en sentral plass.

En utfordring som kan oppstå som en konsekvens av dette spenningsforholdet, er det som kan omtales som «skjult profesjonalisme» (Järvinen, 2012, s. 43). Det handler om motsetningen mellom det som på den ene siden er et ideal om brukermedvirkning, og det som på den andre siden er profesjonsutøverens oppfatning om hva som er det beste for brukeren. Profesjonsutøverne i Järvinens (2012, s. 44) studie beskriver situasjoner der de i lojalitet med idealet om å betrakte brukerne som eksperter i eget liv, holdt sine faglige vurderinger tilbake overfor brukeren. For å løse dilemmaet valgte de heller ulike strategier, for eksempel det noen selv omtalte som «manipulasjon». Det handlet om ikke å formidle sin faglige vurdering direkte til brukeren, men om å sørge for at brukeren likevel kom frem til det «riktige» svaret.

Familieråd bygger på en tanke om at man skal gi innflytelse, men også ansvar for barnets omsorgssituasjon til utvidet familie og nettverk. Enkelte ganger kan det oppstå situasjoner hvor den profesjonelle vurderer at den aktuelle familien ikke vil makte å bære dette ansvaret. Dersom den profesjonelle likevel forplikter seg til idealet i modellen om å gi ansvar for 
beslutninger og gjennomføring av planen til familien, kan man risikere å overse et hjelpebehov. Motsatt kan det oppstå situasjoner der familie og nettverk har høye forventninger om hvordan de kan forbedre barnets omsorgssituasjon - forventninger som den profesjonelle mener er urealistiske. Ved å forplikte seg til idealet om å gi ansvar til familien kan man dermed risikere at barnets omsorgssituasjon ikke blir forbedret. Som det kommer frem av disse eksemplene, kan dilemmaer oppstå mellom verdiene, og spørsmålet er hvordan de profesjonelle håndterer disse.

Fenomenet skjult profesjonalisme illustrerer hvor vanskelig det kan være å manøvrere i spenningsfeltet mellom ulike verdier. Järvinen (2012) beskriver hvordan profesjonsutøverne i hennes studie ikke var særlig stolte av situasjoner der de manipulerte brukere til å komme frem til «riktig» beslutning. Samtidig anså de utfordringene de opplevde i ulike spenningsfelt, som tegn på manglende profesjonalitet, og ikke som en følge av de motstridende idealene og vilkårene de måtte forholde seg til. Slike forklaringer vitner om at det er behov for bevissthet om verdiene og idealene arbeidet er fundert på, og at disse verdiene kan være motstridende når de skal realiseres i praksis. Verdiene om medvirkning og beskyttelse kan dessuten bli tillagt ulik vekt i forskjellige virksomheter og barneverntjenester. For å sikre godt samarbeid og fagutvikling er det derfor viktig å reflektere over hvordan verdiene om beskyttelse og medvirkning vektes og spiller inn i eget og andres arbeid. Spørsmålet som diskuteres videre, er om dette spenningsforholdet drøftes i forskningslitteraturen om familieråd.

\section{Forskning om effekt av familieråd}

En type forskning ser på effekten av familieråd på ulike typer utfallsmål sammenlignet med tradisjonell saksbehandling. I 2014 ble det publisert en norsk kunnskapsgjennomgang om familieråd (Havnen \& Christiansen, 2014). Oppdraget bak og formålet med rapporten var blant annet å gi kunnskap om effekten av familieråd. I arbeidet med rapporten ble det gjort et omfattende litteratursøk, og jeg tar derfor utgangspunkt i denne rapporten. Som Havnen og Christensen (2014, s. 6) skriver, avdekker kunnskapsgjennomgangen først og fremst behov for ytterligere forskning 
på de fleste områder. Den største utfordringen når det gjelder spørsmålet om effekt, handler om problemer med å finne sammenlignbare kontrollgrupper og statistisk kontroll for ulikhet mellom grupper. Med forbehold om tynt forskningsgrunnlag og at de fleste studiene bygger på amerikanske forhold, trekker Havnen og Christensen likevel noen forsiktige konklusjoner. De finner at familieråd øker sannsynligheten for plassering og tilbakeføring til slekt og reduserer sannsynligheten for offentlig plassering. Man finner også at familieråd gir lettere tilgang på hjelpetjenester utenom barnevernet på kort sikt, men ikke på lang sikt (Havnen \& Christiansen, 2014). Ut over dette gir ikke forskningen entydige svar på om bruk av familieråd bidrar til å forebygge mishandling og overgrep, om familieråd fører til kortvarige og mer stabile plasseringer, eller om behov for oppfølging fra barnevernet blir redusert (Havnen \& Christiansen, 2014, s. 108).

Forskningen gir med andre ord ikke entydig svar på om bruk av familieråd bidrar til bedre beskyttelse av barn sammenlignet med tradisjonell saksbehandling. Ut fra denne forskningen ser det ut som at familieråd kan ha betydning når det gjelder å finne fosterhjem i barnets familie og nettverk, men at det ellers kan ha liten betydning for hvilke tiltak barnevernet setter inn (Havnen \& Christiansen, 2014).

En av få studier som har målt effekten av familieråd ved bruk av en randomisert kontrollert studie, fantingen effekt avfamilieråd på utfallsmål som barnas trygghet, stabilitet i plasseringer og endelig utfall i barnas omsorgssituasjon. Forskerne bak studien diskuterer denne manglende effekten av familieråd. De spør om man skal forvente at familieråd har en langtidseffekt på slike ambisiøse utfallsmål, eller om familieråd heller bør ses på som starten av en prosess der forhold som familieengasjement, bedre relasjoner og samarbeid står sentralt (Havnen \& Christiansen, 2014, s. 40).

Effektforskningen har som mål å vurdere modellen ut fra kriterier som handler om beskyttelse. Medvirkning er ikke et utfallsmål i effektforskningen. Som vi ser, stilles det spørsmål ved om det er riktig å vurdere modellen ut fra ambisiøse utfallsmål for beskyttelse, men diskusjoner omkring spenningsforholdet mellom beskyttelse og medvirkning er ikke fremtredende i denne forskningen. 


\section{Forskning om erfaringer med familieråd}

Forskningen om erfaringer med familieråd består av studier som i hovedsak har benyttet intervju eller spørreskjema i etterkant av familierådet. Deltakerne har blitt bedt om å evaluere forberedelsene, selve familierådet, samhandlingen med de profesjonelle og opplevelsen av medvirkning. Havnen og Christiansen (2014, s. 70) konkluderer med at kunnskapsgjennomgangen på dette området viser at et stort flertall av foreldre har positive erfaringer med familieråd. I studiene rapporteres det blant annet om bedre samhold i familien, bedre kommunikasjon og økt nærhet. Forskningen har også vært opptatt av medvirkning. Undersøkelser viste at flertallet opplevde at de hadde fått økt innflytelse på beslutningene.

Når det gjelder barns erfaringer med å delta i familieråd, blir de relasjonelle og prosessuelle sidene ved familieråd trukket frem som viktigere enn selve planen familierådet kommer frem til. Dette dreier seg blant annet om betydningen av at mange voksne i nettverket møtes for å snakke om og konsentrere seg om barnet, at de opplever at de blir sett og hørt, og at det er en positiv atmosfære i familierådet (Havnen \& Christiansen, 2014, s. 81).

Mitchell (2017) diskuterer de relasjonelle og prosessuelle sidene ved familieråd i lys av teorier om empowerment, anerkjennelse og partnerskap. Hennes undersøkelse viste at familieråd bidro til viktige og positive endringer i deltakernes liv. Dette knyttes videre til en diskusjon om hvem som definerer utfall av en tjeneste. Mitchell argumenterer for at deltakernes opplevelse av prosessen må anerkjennes som utfall når myndigheter og organisasjoner vurderer modellens bidrag til barnevernets arbeid (Mitchell, 2017).

Forskningen om erfaringer gir et bredere bilde enn effektforskningen av hva familieråd kan bidra med, fordi deltakerens og de profesjonelles erfaringer blir inkludert i vurderingen. På en side belyses spenningsforholdet mellom beskyttelse og medvirkning i forskningen. Det handler om at forskningen gir grunn for økt optimisme når det gjelder å realisere disse verdiene og spenningen mellom dem. Det knyttes til en forventning om at de relasjonelle prosessene man oppnår ved å inkludere barnet og familien i prosessen, samt ved at man mobiliserer ressurser som ellers ikke har vært utnyttet, kan ha effekter på forhold som er viktige i 
en barnevernsammenheng (Havnen \& Christiansen, 2014, s. 112). Slik jeg tolker det, forstås medvirkning her som en viktig betingelse for å realisere verdien om beskyttelse. På en annen side kritiseres enkelte studier i denne kategorien for mangel på kritisk distanse når det gjelder medvirkning og beskyttelse. Det henger sammen med at denne typen forskning tradisjonelt har vært mer opptatt av erfaringer med selve gjennomføringen og umiddelbare konsekvenser enn av langvarige resultater som beskyttelse mot mishandling på lang sikt (Backe-Hansen, 2006). Forskningen har dessuten vært lite opptatt av om barnet og familien faktisk har hatt innflytelse i prosessen (Backe-Hansen, 2006).

Når det gjelder undersøkelser om brukeres erfaringer, er det viktig å være oppmerksom på at det ikke alltid er samsvar mellom brukertilfredshet og kvalitet (Rolland, 2003, i Slettebø, 2008, s. 92). For eksempel fant Slettebø i sin undersøkelse om foreldres medvirkning i barnevernet at mange mente de hadde gode muligheter for å medvirke. Når de derimot konkret beskrev hvordan de hadde fått medvirke, konkluderte forskerne med at det var på få og uviktige områder de faktisk hadde innflytelse (Slettebø, 2008, s. 167). Av ulike årsaker kan det være vanskelig å uttale seg negativt om hjelpeapparatet i brukerundersøkelser. Det kan for eksempel handle om en frykt for å miste et tiltrengt hjelpetilbud. En annen grunn kan være at informantene hadde lave forventninger til barneverntjenesten i utgangspunktet, og at deres møte med barneverntjenesten var bedre enn forventet (Slettebø, 2008, s. 170). Jeg skal ikke gå nærmere inn på en diskusjon om hva man måler når man spør om brukertilfredshet. Det jeg vil påpeke her, er at det kan være grunn til å undersøke medvirkningsprosessene som skjer i familieråd. Noen forskningsprosjekter har en mer kritisk innfallsvinkel til spørsmålet om hvorvidt man klarer å realisere prinsippet om medvirkning forstått som innflytelse.

\section{Forskning om makt i familieråd}

Forskningen jeg vil omtale her, diskuterer potensialet for maktutjevning og demokratisering ved bruk av familieråd i barnevernet. Studiene skiller seg fra de mer tradisjonelle effekt- og erfaringsstudiene ved at de har et annet forskningsdesign og en tydeligere teoretisk forankring. For det 
første går studiene i dybden på noen få familieråd, og de baserer seg på intervjuer med flere deltakere fra samme familieråd - og i noen tilfeller på observasjon. For det andre diskuteres spørsmålet ut fra teorier om makt og demokratisering i moderne velferdsstater. Studiene bygger slik sett på en erkjennelse og et kritisk blikk på at modeller som legger til rette for medvirkning, innebærer en risiko for å kontrollere familier på en indirekte og skjult måte.

Studier som har utforsket barns deltakelse i familieråd, peker for eksempel på utfordringer med å realisere barns rett til medvirkning. Selv om profesjonelle og andre voksne anerkjenner verdien av å inkludere barnet i prosessen, er barnets innflytelse over beslutningene ofte begrenset (Holland, Scourfield, O'Neill \& Pithouse, 2005; Omre \& Schjelderup, 2009; Strandbu, 2007). Ved å være til stede i flere familieråd fant Omre og Schjelderup også at familiene var usikre i prosessen, og at de var opptatt av å fatte beslutninger som de trodde barnevernet mente var de rette. Familiene ønsket å bli anerkjent av barnevernet og fremstå som ansvarsfulle. Om den private delen av familierådet skriver forfatterne at de profesjonelle har «betydelig innflytelse på de sosiale prosessene og de løsningene som familien kommer frem til» (Omre \& Schjelderup, 2009, s. 151). I en studie fra Wales fant også forskerne at sosialarbeiderne hadde en tendens til å øve innflytelse på oppdraget til familierådet, på agendaene i møtet og på innholdet i handlingsplanen (Holland et al., 2005).

Forskningen gir innblikk i hvordan medvirkningsprosesser kan ta form som skjult maktbruk, som er vanskelig å avdekke av dem som utsettes for den. Flere av forskningsbidragene diskuterer hvordan økonomiske, politiske og ideologiske forhold kan begrense de profesjonelles handlingsrom når det gjelder å realisere verdien om medvirkning. Lupton og Nixon (1999) diskuterer dette i sammenheng med økt søkelys på evidensbasert praksis og økt kontroll over de profesjonelles arbeid. I en studie fra Canada belyser forskerne hvordan byråkratiske, rettslige og nyliberale diskurser begrenset deltakernes handlingsrom (Ney, Stoltz \& Maloney, 2013). Flere peker på at en risikoorientert tilnærming i barnevernet er en barriere når det kommer til å realisere prinsippet om medvirkning. Risikodiskursen blir kritisert for å ha et problemorientert og individorientert fokus (Clifford, Fauske, Lichtwarck \& Marthinsen, 2015). 
Den sterke oppmerksomheten på barn i risiko kan føre til mistenkeliggjøring av foreldres utsagn og virkelighetsforståelse (Wilkins \& Whittaker, 2018). Risikodiskursen bygger dessuten på en utviklingspsykologisk forståelse av at barn er sårbare og umodne snarere enn kompetente aktører som er i stand til å medvirke i beslutninger om sitt eget liv (Strandbu \& Skivenes, 2006). Dersom verdien av beskyttelse og barnevernets kontrollfunksjon blir tillagt stor vekt, skaper det utfordringer med å realisere verdien om medvirkning.

Spenningsforholdet mellom verdiene om beskyttelse og medvirkning blir belyst i forskningen om makt i familieråd. For eksempel diskuterer Holland og kollegaer (2005, s. 67) profesjonaliseringen av familienes beslutningsprosess, som de observerte i sin studie. De skriver at det ikke nødvendigvis er problematisk, men at det tvert imot kan være nødvendig at de profesjonelle setter en viss agenda for møtet for å ivareta barnet. Som de skriver, er det likevel viktig å være bevisst på disse prosessene, og å reflektere over hvordan det passer med idealene om brukermedvirkning og empowerment. Omre og Schjelderup (2009) fremhever betydningen av at barnevernet, i forkant av familierådet, er eksplisitt i vurderingene av hva som er barnets beste, og hva som vurderes som ikke-akseptable tiltak for barnet. På den måten gis familien bedre grunnlag for å ta beslutninger.

Selv om forskningen om makt i familieråd anerkjenner spenningen mellom beskyttelse og medvirkning, er det etter min vurdering en utfordring at forskningen ikke er mer opptatt av at maktutøvelse er en del av barnevernets virksomhet. Det betyr at medvirkning forstått som maktoverføring ikke alltid er mulig eller ønskelig i en barnevernkontekst. Dersom forskningen blir ensidig opptatt av hvem som har makt, og av hvor mye makt som overføres, kan det bidra til en forståelse av makt som noe utelukkende negativt og undertrykkende. En slik oppfatning av makt er utfordrende dersom barnevernet skal utøve sitt mandat om å beskytte barn. Dersom barnevernet skal arbeide etter prinsippet om medvirkning, er det viktig at forskningen tar i betraktning den bestemte konteksten medvirkning skal praktiseres innenfor (jf. Healy, 1998). For å fange opp kompleksiteten i myndiggjøringsbegrepet viser Natland og Malmberg-Heimonen til Foucaults perspektiv på makt i sin analyse av familierådmodellen (Natland \& Malmberg-Heimonen, 2016, s. 52). 
I denne forståelsen av makt er ikke makt utelukkende en materiell ressurs som kan overføres fra en person til en annen. Makt utspiller seg som maktrelasjoner når mennesker samhandler med hverandre. I forlengelse av dette vil jeg skissere en måte å forske på familieråd på som er inspirert av Foucaults maktbegrep

\section{En Foucault-inspirert tilnærming til forskning på familieråd}

Foucault var ikke opptatt av å undersøke hva makt er, eller hvor den kommer fra, men av hvordan den fungerer (Foucault, 1982). Sentralt i Foucaults perspektiv er at en maktrelasjon forutsetter frihet. Det vil si at den personen makten utøves over, er en handlende person. Makt kan ifølge Foucault forstås som handlinger som påvirker handlinger (Foucault, 1982, s. 789). Siden maktrelasjoner kjennetegnes av at de innebærer frihet, vil det alltid være mulighet for motstand. Dette skiller seg fra dominans, der relasjonen er preget av tvang, og der det ikke er mulighet for motstand (Foucault, 1987).

For å forstå den styringsformen Foucault anså som sentral i moderne liberale stater, kan vi se for oss en analytisk trekant der det er en gjensidig relasjon mellom kunnskap, maktrelasjoner og subjektivitet (se for eksempel Foucault, 1991, s. 386-388). Karakteristisk for styringen er at den er tett forbundet med vitenskapelig kunnskap. Maktutøvelsen kjennetegnes av at det er en velmenende makt, der målet er å styrke og forbedre kapasiteter og egenskaper i befolkningen. Innenfor denne styringsformen posisjoneres individet som en ansvarlig, aktiv og handlende aktør som oppfordres til å inngå i styring av seg selv (Foucault, 2002). Individets frihet utøves dermed innenfor visse rammer som allerede er konstituert av bestemte former for kunnskap, maktrelasjoner og subjektivitet. Et eksempel på en slik maktrelasjon kan være i relasjonen mellom en profesjonell og en bruker, der målet er å påvirke brukerens oppfatninger og handlinger. Den profesjonelle oppnår ikke målet ved hjelp av tvang eller ved å gå imot brukerens vilje. I relasjonen posisjoneres brukeren som en autonom aktør som er i stand til å styre seg selv på en ansvarlig måte. Gjennom veiledning blir brukeren oppfordret til å handle i tråd med faglige (vitenskapelige) 
oppfatninger. Brukerens frihet utøves dermed innenfor rammen av å være en aktiv, ansvarlig og selvstyrt aktør som handler i tråd med bestemte oppfatninger, for eksempel om hvordan å være en god forelder.

Et viktig poeng er at Foucaults maktbegrep åpner for at makt ikke utelukkende ses som noe negativt og undertrykkende, men også som noe positivt og produktivt. Dersom man lar seg inspirere av dette maktbegrepet i forskning på familieråd, vil man være mindre opptatt av hvem som har makt. Oppmerksomheten rettes mot hvordan makten utspiller seg. Poenget her er å fremheve at maktbegrepet åpner for å forstå profesjonelt arbeid som maktutøvelse, uten at det trenger å ha et negativt fortegn. I en barnevernkontekst kan det for eksempel handle om å gi informasjon til familie og nettverk om konsekvenser av å vokse opp i familier med vold og høy konflikt. Selv om det kan karakteriseres som maktutøvelse at barnevernet setter agenda og definerer situasjonen ut fra sin fagkunnskap, er det ikke nødvendigvis å betrakte som en undertrykkende makt. Et sentralt mål med familierådmodellen er at metoden skal være sensitiv for alternative måter å forstå omsorg og barndom på. Barnets og familiens stemmer skal komme frem, og det er derfor et mål at de profesjonelle trer til side og gir familien handlingsrom. Samtidig skal barnevernet arbeide for å sikre barnets beskyttelse. Profesjonelt skjønn og fagkunnskap kan bidra til å nå dette målet. Dersom forskningen skal kunne anerkjenne spenningsforholdet mellom beskyttelse og medvirkning i familieråd, kan det derfor være fruktbart med et maktbegrep som gir rom for at maktutøvelse også kan være produktiv.

Et annet poeng i Foucaults analyser som er relevant for forskning på familieråd, handler om at maktutøvelse ofte kombineres med demokratiske idealer i moderne stater (Foucault, 2002). Siden makt, ifølge Foucault, ikke handler om tvang, men arbeider gjennom individenes frihet, er den ofte vanskelig å oppdage. Foucault (2002) viser hvordan praksiser fremstilles som demokratiske møteplasser som er fri for maktutøvelse, samtidig som friheten utøves innenfor bestemte rammer der kunnskap, maktrelasjoner og subjektivitet allerede er gitt og fastlagt på forhånd. Når makten «skjules» for de involverte aktørene på denne måten, blir maktutøvelsen det Foucault (2002, s. 93) omtaler som «demonisk». Et viktig poeng er at dette ikke nødvendigvis er uttrykk for aktørenes intensjoner, 
men et resultat av et komplekst nettverk av maktrelasjoner som er involvert i styringen i moderne stater (Foucault, 1999, s. 106).

Inspirert av dette perspektivet vil oppmerksomheten i forskningen på familieråd rettes mot hvordan makten fungerer. Familieråd bygger eksplisitt på demokratiske idealer. Samtidig vil det alltid være en asymmetrisk relasjon mellom barnevernet og familien. Barnevernet er et kunnskapsfelt som bygger på vitenskapelig kunnskap, for eksempel om barns utvikling. I tillegg må man ta i betraktning at gjennomføringen av et familieråd bare er en liten del av en barnevernssak. Mange vurderinger og beslutninger er gjort før familien inviteres inn til å diskutere løsninger, og det reelle handlingsrommet kan derfor være svært begrenset. I forskning på familieråd vil det derfor være relevant å undersøke om barnevernets ansatte er tydelige når det gjelder å kommunisere til barn og familier hvilken posisjon de har, og hvilke forventinger de har til familien. Er for eksempel barnevernets ansatte eksplisitte i sine vurderinger av hva de mener er barnets beste? Kommuniserer de til familien hva de mener er ikke-akseptable tiltak? Uttales deres posisjon og vurderinger direkte, eller holdes dette «skjult» for deltakerne i familierådet? I en undersøkelse inspirert av dette perspektivet vil det også være relevant å undersøke hva slags kunnskap som legges til grunn for vurderingene, om denne kunnskapen formidles til deltakerne, og om det er mulig å utfordre denne. I familieråd inviteres deltakerne til å bidra med sin erfaringskunnskap. Dersom denne kunnskapen på forhånd blir vurdert som mindre verdifull enn den vitenskapelige kunnskapen ansatte i barnevernet besitter, foregår deltakernes medvirkning innenfor bestemte rammer som allerede er fastlagt. Dette kan skape prosesser der maktutøvelsen er vanskelig å avdekke.

\section{Avslutning}

På grunn av endringer i barnevernloven som forplikter barnevernet til å legge til rette for medvirkning og nettverksinvolvering, er det grunn til å anta at vi vil se økt bruk av familierådmodellen i tiden som kommer. Dersom forskningen om familieråd skal være nyttig for praksisfeltet og komme brukerne til gode, er det viktig at forskningen anerkjenner de 
faktiske vilkårene som preger barnevernets arbeid. I dette kapitlet har jeg løftet frem spenningsforholdet mellom beskyttelse og medvirkning.

Forskning kan gi svar ut fra de spørsmålene forskningen stiller. Effektforskningen forsøker å gi svar på hva som er effekten av familieråd når det gjelder å arbeide for at barn som har behov for det, får den beskyttelsen de trenger. Forskningen om erfaringer har som mål å beskrive deltakernes erfaringer med gjennomføring og konsekvenser av familieråd. De positive resultatene i forskningen om erfaringer bidrar til optimisme med tanke på potensialet for å realisere verdiene om medvirkning og beskyttelse. Samtidig blir forskningen kritisert for å være for lite opptatt av om modellen bidrar til beskyttelse av barn på lang sikt, og om deltakerne i familieråd har reell innflytelse i prosessen. I kapitlet har jeg vist til forskning som ser kritisk på maktforhold i familieråd. Enkelte forskningsbidrag i denne kategorien belyser og anerkjenner spenningsforholdet mellom beskyttelse og medvirkning. I forlengelse av dette har jeg skissert en tilnærming til forskning på familieråd som er inspirert av Foucaults perspektiv på makt.

Siden barnevernarbeid er forankret i normative verdibegreper, og siden arbeidet med familieråd i stor grad aktualiserer et spenningsforhold mellom verdiene beskyttelse og medvirkning, er det grunn til å stille spørsmål som drøfter dette spenningsforholdet. I analysen rettes dermed søkelyset mot hvordan makt utøves, og om maktutøvelsen er skjult eller åpen og uttalt. Dette krever studier av konkrete familierådpraksiser der det analytiske perspektivet er rettet mot å avdekke skjult maktbruk, men også mot å vise at maktutøvelse kan være produktiv og bidra til å åpne for motstand. Perspektivet vil kunne romme at både beskyttelse og medvirkning er sentrale verdier i arbeidet, og at det kan oppstå dilemmaer når disse skal forenes. Perspektivet kan slik sett bidra til bevisstgjøring av verdiene som preger arbeidet og utviklingen av bruken av familieråd i barnevernet.

\section{Litteratur}

Arnstein, S. (1969). A ladder of citizen participation. Journal of American Institute of Planners, 35(4). https://doi.org/https://doi.org/10.1080/01944366908977225 
Backe-Hansen, E. (2006). Hvordan virker familieråd? Et internasjonalt perspektiv. I S. Falck (red.), Hva er det med familieråd? Samlerapport fra prosjektet: «Nasjonal satsing for utprøving og evaluering av familieråd $i$ Norge» (NOVA-rapport 18/2006). Oslo: Norsk institutt for forskning om oppvekst, velferd og aldring.

Barnevernloven. (1992). Lov om barneverntjenester (LOV-1992-07-17-100). Hentet fra https://www.lovdata.no

Clifford, G., Fauske, H., Lichtwarck, W. \& Marthinsen, E. (2015). Minst hjelp til dem som trenger det mest? Sluttrapport fra forsknings- og utviklingsprosjektet «Det nye barnevernet» (NF-rapport 6/2015). Bodø: Nordlandsforskning.

Foucault, M. (1982). The subject and power. Critical Inquiry, 8(4), 777-795. https:// doi.org/10.1086/448181

Foucault, M. (1987). The ethic of care of the self as a practice of freedom. I D. M. Rasmussen \& J. W. Bernauer (Red.), The final Foucault. Cambridge: MIT Press.

Foucualt, M. (1991) Polemics, poletics, and problematizations. An interview with Michel Foucault. I P. Rabinow (Red.), The Foucault reader. London: Penguin Books Foucault, M. (1999). Seksualitetens historie 1: Viljen til viten. Oslo: Exil.

Foucault, M. (2002). Forelesninger om regjering og styringskunst. Oslo: Cappelen Damm Akademisk.

Hart, R. A. (1992). Children's participation. From tokenism to citizenship. Firenze: UNICEF Innocenti Research Centre.

Havnen, K. \& Christiansen, Ø. (2014). Kunnskapsstatus om familieråd. Erfaringer og effekter. Bergen: Regionalt kunnskapssenter for barn og unge (RKBU Vest), Uni Research Helse.

Healy, K. (1998). Participation and child protection. The importance of context. British Journal of Social Work, 28(6), 897-914.

Holland, S., Scourfield, J., O’Neill, S. \& Pithouse, A. (2005). Democratising the family and the state? The case of family group conferences in child welfare. Journal of Social Policy, 34(1), 59-77. https://doi.org/10.1017/Soo47279404008268

Järvinen, M. (2012). Fra afhængighed til autonomi - at arbejde med stofbrugere. I M. Järvinen \& N. Mik-Meyer (Red.), At skabe en professionel. Ansvar og autonomi i velferdsstaten. København: Hans Reitzels Forlag.

Järvinen, M. \& Mik-Meyer, N. (2012). At skabe en professionel. Ansvar og autonomi i velfordsstaten. København: Hans Reitzels forlag.

Lupton, C. \& Nixon, P. (1999). Empowering practice? A critical appraisal of the family group conference approach. Bristol: The Policy Press

Mitchell, M. (2017). Re-imagining family group conferencing 'outcomes'

(Doktoravhandling). The University of Edinburgh, Edinburgh. Hentet fra https:// era.ed.ac.uk/handle/1842/31278

Natland, S. \& Malmberg-Heimonen, I. (2016). Familieråd-frigjørende sosialt arbeid innenfor en manualbasert modell? Tidsskrift for velferdsforskning, 19(1), 44-61. 
Ney, T., Stoltz, J. A. \& Maloney, M. (2013). Voice, power and discourse. Experiences of participants in family group conferences in the context of child protection. Journal of Social Work, 13(2), 184-202. https://doi.org/10.1177/1468017311410514

Omre, C. \& Schjelderup, L. E. (2009). Barn i barnevernet. En studie om barns deltakelse og styrkeprosesser i familieråd. Trondheim: Tapir Akademisk Forlag.

Paulsen, V. \& Studsrød, I. (2019). Barnet i sentrum for barnevernsbedagogens yrkesutøvelse. I Studsrød, I., Paulsen, V., Kvaran, I. \& Mevik, K. (Red.), Barnevernspedagog. En grunnbok. Oslo: Universitetsforlaget.

Qvortrup, J. (2010). Om børns rettigheder i voksensamfundet. I A. T. Kjørholt (Red.), Barn som samfunnsborgere - til barns beste? (s. 30-46). Oslo: Universitetsforlaget.

Rolland, A. (2003). Brukernes tilfredshet eller tjenestens kvalitet? Tidsskrift for Velferdsforskning, 6(1), 56-60.

Saus, M., Jenssen, T. \& Strandbu, S. (2017). Mellom entusiasme og anvendelse Barnevernsarbeideres oppfatninger og erfaringer med familieråd. Tidsskriftet Norges Barnevern, 94(01), 54-70. https://doi.org/10.18261/issn.1891-1838-2017-01-05

Slettebø, T. (2008). Foreldres medbestemmelse i barnevernet. En studie av foreldres erfaringer med individuell og kollektiv medvirkning (Doktoravhandling). Norges teknisk-naturvitenskapelige universitet, Trondheim.

Strandbu, A. (2007). Barns deltakelse og barneperspektivet i familierådsmodellen (Doktoravhandling). Universitetet i Tromsø, Tromsø.

Strandbu, A. \& Skivenes, M. (2006). A child perspective and children's participation. Children, Youth and Environments, 16(2), 10-27.

Wilkins, D. \& Whittaker, C. (2018). Doing child-protection social work with parents: What are the barriers in practice? British Journal of Social Work, 48(7), 20032019. https://doi.org/10.1093/bjsw/bcx139 



\title{
Bekymring for det ufødte liv og omsorgsovertakelse ved fødsel: Posisjoner, verdikonflikter og spenninger i tverrfaglig arbeid
}

\author{
Kerstin Söderström
}

\author{
Høgskolen i Innlandet, Sykehuset Innlandet HF
}

\begin{abstract}
Separating a mother and newborn at the maternity ward is a challenging, potentially traumatic, and value-laden intervention. Cross-disciplinary collaboration in this tense and intense situation ideally assists child protection services in reaching well-founded decisions. However, differing opinions, professional stances and values can jeopardize the decisional process and threaten the quality of care and rights of the client(s). The main aim is to describe and analyse cross-disciplinary teamwork during pregnancy and the process towards a child protection decision. Participant observation and interviews provided data and descriptions of the case study, analysed according to positioning theory. The results show how two main storylines, a medical-therapeutic and a child protection storyline, each with a set of professional positions, create friction and tension in cross-disciplinary collaboration. The case describes the initial tensions, how they were overcome, and how they finally resulted in a planned removal at birth. This gave the mentally ill mother-to-be the opportunity to participate and prepare for the separation. The study demonstrates how a supervised, structured and reflective collaborative process enabled the participants to deal with conflicts and uncertainties stemming from positions and the dynamics of positioning. Further research and practical experiences, e.g. through simulation training, are needed to inform safe and caring removal practices and validate the usefulness of positioning theory to illuminate interprofessional conflict.
\end{abstract}

Keywords: child protection, removal at birth, interdisciplinary collaboration, positioning theory, professional values

Sitering av denne artikkelen: Söderström, K. (2020). Bekymring for det ufødte liv og omsorgsovertakelse ved fødsel: Posisjoner, verdikonflikter og spenninger i tverrfaglig arbeid. I H. Nordby \& A. Halsa (Red.), Verdier i barnevern (Kap. 7, s. 131-151). Oslo: Cappelen Damm Akademisk. https://doi. org/10.23865/noasp.103.ch7

Lisens: CC BY-ND 4.0 


\section{Familiens spede begynnelse}

Noen barn er vi bekymret for før de er født. Noen nyfødte trenger barnevern fra starten av. Mellom 30 og 40 barn blir hvert år separert fra foreldrene like etter fødsel (Skogstrøm, 2019). Et slikt inngrep skjer i en unik, intim, inntrykksøm og meningsmettet situasjon, hvor det normale er at foreldre og barn "pakkes inn» i omsorg og hensyntagen. omsorgsovertakelse ved fødsel er verdiladd og vekker særdeles sterke følelser og reaksjoner. Det regnes som barnevernets mest inngripende tiltak nest etter tvangsadopsjon (NOU, 2016: 16).

En uforberedt separasjon like etter fødsel er dramatisk og traumatisk for foreldre og er også vanskelig for involverte profesjonelle. Hendelsen kommer ofte brått på og oppleves etisk, faglig og personlig krevende (Marsh, Robinson, Leamon \& Shawe, 2014). Ikke sjelden oppstår spenninger mellom samarbeidsparter som må løses. For det alvorlige bakteppet til inngrepet og annet forebyggende spedbarnevern er at nyfødte, i likhet med eldre barn, utsettes for omsorgssvikt og vold.

Rettsmedisinsk institutt anslår at mellom åtte og ti barn under tre år dør hvert år som følge av drap, mishandling eller omsorgssvikt (Rognum, 2016). I perioden 2015-2018 var det 90 alvorlige voldshendelser mot barn under fire år. Over halvparten var fem måneder eller yngre da skaden ble avdekket (Politiet, 2019). I barnevoldsutvalgets offentlige gransking av 20 alvorlige barnevernssaker (NOU, 2017: 12) konkluderes det med at sviktende samarbeid og samordning mellom ulike hjelpetjenester er årsaken til at for mange utsatte barn ikke blir beskyttet. 70 prosent av norske familier i barnevernet får tjenester fra fem eller flere instanser (Clifford, 2015). Men å komme i posisjon og sette et godt tverrfaglig samarbeid allerede i svangerskapet er krevende av ulike grunner. Det kan være juridiske eller formelle skranker, avstand mellom tjenester og manglende eller dårlige erfaringer med tverrprofesjonell samhandling. Det handler også om ulike personer og profesjoners fagetikk og verdier, kort sagt, om ulike oppfatninger om hva som er riktig å gjøre.

Dette kapitlet beskriver en tverrfaglig arbeidsprosess rundt sterk bekymring for en gravid og hennes ufødte barn. Målet er å synliggjøre kompleksiteten i barnevernarbeid i livets begynnelse, og hvordan posisjonering utfordrer tverrfaglig samarbeid. Spenninger mellom tjenester 
viser seg gjerne ved første øyekast som ulike faglig begrunnede meninger. I dette kapitlet forsøker jeg å gå bak det som sies åpent, og å forstå konflikt og spenninger ved å analysere tjenestenes og fagfolkenes ulike posisjoner, mandat og verdibaserte holdninger. Det sentrale spørsmålet er: Hvordan ser det tverrfaglige samarbeidet rundt omsorgsovertakelse ved fødsel ut, og hvordan påvirkes barnevernets beslutninger av deltagernes (profesjonenes) faglige orientering og posisjon?

Arbeidet som presenteres her, inngår i en større undersøkelse av barnevernets verdier, begrunnelser og beslutningsprosesser. Tematikken omsorgsovertakelse ved fødsel kan brukes som et forstørrelsesglass for dynamikker, konflikter og samarbeidsmuligheter som oppstår i mange av barnevernets andre oppgaver. Her forsterkes og fokuseres beskyttelsesoppdraget, Det er ofte ulike meninger om nødvendigheten av å gripe så sterkt inn, og spenninger i samarbeidet og samfunnets verdier og normer utfordres.

\section{Tverrfaglig posisjonering}

I tverrfaglig samarbeid er det en blanding av deltagerens fagkunnskap, formelle forpliktelser, verdier, interesser, fagetiske holdninger og personlige overbevisninger som spilles ut. Konflikter eller uenighet i samarbeidet oppfattes gjerne som faglig uenighet, eller som at den man er uenig med, er en vanskelig eller inkompetent fagperson. Antagelsen i dette kapitlet er at årsakene er mer komplekse, og at de blant annet har sammenheng med fagfolkenes posisjoner og posisjoneringsprosesser i samarbeidet.

En posisjon beskrives av Harré og Slocum (2003) som et knippe av ansvar, forpliktelser og rettigheter som en fagperson har eller tilskrives i en bestemt situasjon. En gitt posisjon påvirkes av felles oppfatninger av hvordan disse forholdene er fordelt mellom aktørene (Harre \& Moghaddam, 2012). Posisjoner kan svekkes, forsterkes og forhandles i løpet av en sosial episode. En faglig posisjon er sjelden verdinøytral og heller ikke uberørt av fagpersonens private jeg. En posisjon er i denne teorien mer fleksibel og foranderlig enn for eksempel en sosial rolle, og den beskriver bedre det dynamiske samspillet i sosialt samvær.

Vi tilpasser oss etablerte posisjoner, egen og andres, uten å tenke over det. Men posisjoner kan også fornektes, utfordres og forhandles. En slik 
interaktiv prosess kalles posisjonering, det sentrale omdreiningspunktet i posisjoneringsteori (Tirado \& Gálvez, 2007) som brukes som analytisk grep i dette kapitlet. Posisjonering av seg selv innebærer alltid en posisjonering av den andre, og posisjonering av den andre er samtidig en posisjonering av seg selv (Bullough \& Draper, 2004). Posisjon og posisjonering forteller om deltagernes oppfatninger av en moralsk orden, om ulikheter i fordelingen av oppgave, makt og myndighet. Begrepene sier også noe om den enkelte deltagers plass i et hierarki.

Tirado og Gálvez (2007) anser posisjoneringsteori som særlig egnet for å analysere konflikt i samhandling, både på grunn av oppmerksomheten på dynamiske endringer underveis i en sosial episode og på grunn av oppmerksomheten på underliggende oppfatninger og verdier som muligens driver konflikten. Nordby (2017, s. 38) definerer konflikt i et samarbeid som at «to eller flere personer som er avhengige av hverandre, er i en konflikt hvis de er så uenige om en sak at det har betydelig negativ effekt på samarbeidet dem imellom». Det er videre situasjoner der ulikheter i interesser og overbevisning gjør det umulig at partenes mål eller mening om hva som er best å gjøre, kan bli oppfylt samtidig (Tirado \& Gálvez, 2007). Det er for eksempel en konflikt i samarbeidet hvis en part er overbevist om at det beste for barnet er å bli værende hos foreldrene, og den andre parten mener at det beste er å adskille og plassere barnet i fosterhjem.

\section{Hva vet vi om omsorgsovertakelse ved fødsel?}

Å separere et nyfødt barn fra mor er noe av det vanskeligste ansatte i helseog omsorgsprofesjoner håndterer. Det er likevel relativt lite oppmerksomhet på dette i forskningslitteraturen, i jordmor- og barnevernutdanningene og i det tverrfaglige praksisfeltet. Det finnes heller ingen nasjonale retningslinjer for hvordan omsorgsovertakelse ved fødsel bør foregå (Odland, 2018). Statistikken om barnevernets arbeid i perinatalfasen og omsorgsovertakelse ved fødsel er mangelfull og forteller lite om prosessen fra fødsel til et eventuelt omsorgstiltak (Dyrhaug, 2019; Jacobsen, 2019).

Men noe vet vi. I 2008 var det 34 tilfeller av separasjon like etter fødsel etter barnevernlovens $\$$ 4-9 jf 4-8 2.2 (bvl, 1992). Forekomsten økte 
gradvis fram til 2013 da det var 65 separasjoner etter den såkalte nyfødtparagrafen (Dyrhaug, 2019). En tilsvarende sterk økning i antall saker ble også registrert i England i samme tidsperiode (Broadhurst, Alrouh et al., 2015). Internasjonal forskning viser at kvinner som mister ett barn ved fødsel, gjerne mister flere (Broadhurst, Shawb et al., 2015; Cox, 2012; Grant et al., 2014).

Økningen av barneverntiltak overfor spedbarn i Norge ble beskrevet som gledelig av Barne-, ungdoms- og familiedirektoratets direktør. Det er en ønsket utvikling å komme inn med tiltak så tidlig som mulig for å beskytte barn mot forventede belastninger på grunn av omsorgssvikt (Jensen, Fredrikstad, Saabye \& Haugen, 2016). Fra 2014 har det vært en nedgang i separasjoner på barselavdelingen, og i hele 2018 var det registrert 30 hendelser. Det er fortsatt en økning i barneverntiltak for de minste i tråd med tidlig inn-strategien. I 2018 var det 558 barn under ett år som fikk tiltak i barnevernet. 58 av disse ble plassert i fosterhjem (Jacobsen, 2019).

En gjennomgang av alle 58 omsorgsovertakelser i Norge i 2015 og 2016, foretatt av doktorgradsstipendiat Ida Juhasz, viste at i 55 prosent av sakene hadde foreldrene mistet omsorgen for et barn tidligere. Den hyppigste årsaken til omsorgsovertakelsen var mors psykiske helse (71 prosent), deretter mors evnenivå og på tredjeplass rusavhengighet. Mange av mødrene selv hadde vært barn i barnevernet, og i 27 prosent av sakene var foreldrene enige $\mathrm{i}$ at barnet ble plassert hos andre (Jakobsen, 2018).

Jordmødre som har deltatt i akutt omsorgsovertakelse ved fødsel, rapporter misnøye med arbeidet, sinne, skyldfølelse, frustrasjon og tanker om å gi opp sitt yrke (Marsh et al., 2014). Jordmødre blir involvert i handlinger som oppleves i strid med deres faglige oppgave om å gi pleie og omsorg, og oppfølgingen av foreldre etterpå oppleves som mangelfull (Everitt, Fenwick \& Homer, 2015). Hvordan dette oppleves for andre yrkesgrupper som involveres, for eksempel fastlege, psykisk helsevern og politi, er i svært liten grad studert.

Yrkesgruppen som må ta de vanskeligste beslutningene og foreta de mest krevende handlingene, og som må stå sterkest i stormen, er likevel barnevernet. Dersom det ikke har vært et samarbeid med den gravide før fødsel, har barnevernet liten tid til å undersøke bekymringen 
og fatte beslutninger. Barnevernansatte må være forberedt på kritikk, endog hat fra foreldre og deres støttespillere. De blir hengt ut i sosiale medier og kritisert i de konvensjonelle nyhetskanalene. Samarbeidsparter kan uttrykke misnøye med barnevernets handlinger, men kritikk kan også forventes hvis de ikke griper inn.

Barnevernarbeideren føler seg dårlig forberedt på mange av yrkets alvorlige og kompliserte oppgaver. Barne-, ungdoms- og familiedirektoratets (Bufdir) utredning av kompetansebehovene i barnevernet viste at kun 35 prosent av ansatte i barneverntjenesten mener at grunnutdanningen deres i stor eller svært stor grad ga dem et godt grunnlag for å arbeide i tjenesten (BUFdir, 2019). Høyt sykefravær (Johansen, 2014) og høy turnover i barneverntjenestene (Slettebø et al., 2019) forteller om blant annet overveldelse, stress og andre arbeidsbelastninger.

\section{De juridiske og formelle rammene for foster- og spedbarnevern}

Lov om barneverntjenester (barnevernloven [bvl.], 1992) skal sikre at barn og unge som lever under forhold som kan skade deres helse og utvikling, får nødvendig hjelp, omsorg og beskyttelse til rett tid (bvl., 1992, \$ 1-1). Hovedregelen er at barnevernet ikke har ansvar for det ufødte barnet, og dermed er det ikke anledning til å åpne barnevernssak og undersøke en bekymring under svangerskapet uten at den gravide selv ønsker det. Det eneste unntaket til kravet om samtykke gjelder gravide rusavhengige som er tvangsinnlagt etter helse- og omsorgstjenesteloven paragraf 10-3 syvende ledd (helse- og omsorgstjenesteloven, 2011). I forarbeidene til ny barnevernlov (Barne- og familiedepartementet, 1992) ble det drøftet hvorvidt ufødte barn burde omfattes av meldeplikten til barnevernet, men flertallet mente at det ville være for hardt for den gravide å vite om en forestående omsorgsovertakelse samtidig som hun bar frem barnet.

Når helsepersonell får bekymring for det ufødte liv, og for hvordan omsorgssituasjonen vil bli etter fødsel, kan de velge å informere den gravide, eventuelt begge blivende foreldre, om barnevernets tjenester og foreslå en frivillig kontakt. Hvis kvinnen takker nei, er helsepersonell 
bundet av taushetsplikt etter paragraf 21 i helsepersonelloven (1999), og de kan ikke informere barneverntjenesten eller andre tilstøtende tjenester. Dersom barnevernet allerede er kjent med den gravide og de forholdene som vekker bekymring for et ufødt eller nyfødt barn, kan likevel ikke barnevernet åpne en undersøkelsessak i svangerskapet uten den gravides samtykke. Denne lovgivningen signaliserer at kvinnens selvråderett står sterkt, og hun tilkjennes det ultimate ansvaret for livet hun bærer på. Etter at barnet er født, trer barnevernets grunnleggende mandat i kraft, og barnevernets inntreden forutsetter ikke foreldresamtykke. Som nevnt over er det eneste unntaket der hvor en gravid kvinnes rusmiddelbruk vurderes å være overveiende sannsynlig til skade for fosteret. Da har helsepersonell opplysningsplikt (helsepersonelloven, 1999, § 32), og kommunal sosialtjeneste kan gripe inn og gjennomføre en tvangsinnleggelse, selv om det strider imot kvinnens eget ønske og valg (helse- og omsorgstjenesteloven, 2011).

Det som benevnes som omsorgsovertakelse av et nyfødt barn, er egentlig en akuttbestemmelse som gir barneverntjenesten anledning til å «holde tilbake» et nyfødt barn som enda ikke har «flyttet til foreldrene», dersom det å reise hjem sammen med foreldrene medfører en situasjon som overveiende sannsynlig setter barnet liv og helse i fare. I praksis betyr det at barnevernet henter barnet på barselavdelingen kort tid etter fødselen med hjemmel i barnevernloven paragraf 4-9, jf. paragraf 4-8, andre ledd (bvl., 1992).

\section{Retten til familieliv og barnets beste}

Familieliv er beskyttet av internasjonale og nasjonale lover og sentralt står artikkel 8 i Den europeiske menneskerettighetskonvensjonen (EMK) (Menneskerettsloven, 1999), som verner om følgende:

[Retten til] respekt for sitt privatliv og familieliv, sitt hjem og sin korrespondanse. ... Det skal ikke skje noe inngrep av offentlig myndighet i utøvelsen av denne rettighet unntatt når dette er i samsvar med loven og er nødvendig i et demokratisk samfunn av hensyn til den nasjonale sikkerhet, offentlige trygghet eller landets økonomiske velferd, for å forebygge uorden eller kriminalitet, for å beskytte helse eller moral, eller for å beskytte andres rettigheter og friheter. 
Når foreldre som mener at barnevernet har gjort urett får prøvd sin sak for Den europeiske menneskerettsdomstolen (EMD) i Strasbourg, er anken ofte begrunnet i EMKs artikkel 8 (Hansen, 2019). En rekke studier med juridiske, menneskerettslig perspektiver dokumenterer at EMK og EMD forutsetter en høy terskel for omsorgsovertakelse ved fødsel (for eksempel Freel, 2010; Sandberg, 2005; Søvig, 2019). Norges institusjon for menneskerettigheter (NIM) sier det slik: «[A]kuttvedtak for et nyfødt barn ifølge EMD er et ekstremt strengt tiltak, og [...] det må ekstraordinært tvingende grunner til før en baby kan bli fysisk fjernet fra sin mor mot hennes vilje rett etter fødsel» (Skogstrøm, 2019).

I tillegg til en eksepsjonell sterkt juridisk begrunnelse forventer både nasjonale og internasjonale domstoler at andre tiltak for å beskytte barnet har vært forsøkt, blant annet systematisk tverrfaglig innsats for å styrke foreldrekompetansen, beskytte barnet og sikre dets utvikling (f.eks. Freel, 2010). De siste årene har det vært en viss dreining i EMD mot å vektlegge barnets beste fremfor privatlivets fred (Helland, 2019).

Familielivet er altså lovregulert og beskyttet, men sterkere enn retten til å være sammen som familie og privatlivets fred er hensynet til barnets beste, slik det formuleres i Barnekonvensjonen (1989) artikkel 3. De nordiske landene har en lavere terskel enn andre kulturer for å tilsidesette familiens rett til å være samlet og i fred dersom dette familielivet vurderes å være til skade for barn (Gording Stang, 2019). Både terskelen og barnevernets begrunnelser, faglighet og handlinger er gjenstand for kritikk fra både norsk (Witoszek, Totland, Nwosu, Thune \& Salvesen, 2015) og internasjonalt hold og fra EMD (Søvig, 2019).

\section{Tverrfaglig samarbeid}

Der hvor det er barnevernbekymring for det ufødte liv, er det som regel sammensatte og alvorlige problemer med behov for flere hjelpeinstanser (Söderström, 2011). Ulike fag og tjenester har kunnskap om forskjellige sider av problemene og behovene, og de rår over ulike metoder og tiltak. Jordmor eller fastlege skal følge opp svangerskap og fosterhelse, og helsesykepleier skal ta over etter fødsel. Når det er risiko for svangerskapseller fødselskomplikasjoner, henvises den gravide til kvinneklinikk i 
spesialisthelsetjenesten. Har hun en psykisk lidelse eller et rusproblem, er det ofte kontakt med saksbehandler og terapeuter i både kommune og spesialisthelsetjeneste. Blir problemene alvorlige eller akutte, kan en innleggelse i psykisk helsevern være aktuelt. Assistanse fra NAV må til hvis det trengs bistand til økonomi eller bolig. Kommunale lavterskeltilbud eller sped- og småbarnsteam fra psykisk helsevern for barn og unge (BUP) kan jobbe med forberedelse til foreldreskapet. Familievernkonvensjonen kan adressere utfordringer i parforholdet. Hvis det vurderes å være behov for langvarig hjelp fra flere instanser, har personen det gjelder, krav på en koordinerende individuell plan (Pasientrettighetsloven, 1999/2019). Når samarbeidet glir godt, vil sannsynligvis både avgjørelser og tiltak bli bedre. Mange av disse tjenestene og profesjonene vil dukke opp senere i kapitlet som aktører i fortellingen om gravide «Maria», der de inngår i det tverrprofesjonelle hendelsesforløpet frem til fødsel. Samarbeidsprosessen utgjør denne studiens empiri.

Selv om det er allmenn aksept for behovet for tverrfaglig samarbeid, og flere lover gir generelle pålegg om å samarbeide, mangler det beskrivelser av hvordan dette samarbeidet bør foregå (NOU, 2017: 12). Flere tilsyn og granskinger av alvorlige barnevernssaker, inklusive barnevoldsutvalget (NOU, 2017: 12), dokumenterer at kommunikasjonen og samarbeidet mellom tjenestene ofte svikter. Tjenestenes kvalitetsindikatorer er «innovervendt» for å sikre etterlevelse av den enkelte tjenestes driftskrav, mens det er svakere insentiver til å prioritere det man kan kalle en «mellomromskompetanse». Men det mener jeg kompetanse til å arbeide i mellomrommet mellom tjenester, til å sikre kvalitet i samarbeidet og kunne utnytte ulikheter for å utfylle hverandre - og slik styrke helhet og sammenheng i det totale tjenestetilbudet.

I det følgende presenterer jeg en kasuistikk og samarbeidsprosess som forsøker å tette hullene mellom tjenestene for å hjelpe den problembelastede, gravide Maria og hennes ufødte barn.

\section{Maria og de mange hjelperne}

Maria er ung, utsatt og psykisk syk. Hun har mange sosiale og relasjonelle problemer, og hun trenger hjelp til bolig og økonomi og til å få 
hverdagen til å henge sammen. I perioder får hun døgnbehandling $\mathrm{i}$ psykisk helsevern. Svangerskapet var ikke planlagt, men etter den første overraskelsen våknet forestillingene om å bli mor. Samtidig steg en motivasjon til å få orden på livet og et gryende håp om å beholde barnet. Hun ga gyldig samtykke til samarbeid med barnevernet, og til at de involverte hjelpeinstanser kunne snakke sammen for å hjelpe henne og barnet. En tverrfaglig gruppe ble etablert med mål om å følge Maria til barnet var født, og lenger hvis nødvendig. Marias og barnets skjebner var mer eller mindre i hjelpernes hender, med deres ulike kunnskaper, verdier og agendaer.

\section{Metode}

Fortellingen om Maria baserer seg på et reelt tverrfaglig samarbeid som involverte ni profesjonelle aktører. Disse var virksomhetsleder for kommunens helse- og sosialtjeneste, ansatt i kommunal rus-/psykisk helsetjeneste, fastlege, jordmor i kommune, jordmor på sykehus, helsesøster, barnevern, psykisk helsevern for barn (BUP) og psykisk helsevern for voksne (sykehus). I tillegg deltok en ekstern prosessveileder. Forfatteren hadde en rolle som deltagende observatør, som noterte under samhandlingsprosessen på to møter og fikk skriftlig referat fra de øvrige. I etterkant ble flere av aktørene intervjuet. Maria samtykket til at de profesjonelle kunne møtes uten henne, og til at prosessen ble observert. Navnet «Maria» er fiktivt, og detaljer er endret eller utelatt for å sikre anonymitet. Det tverrprofesjonelle samarbeidet som beskrives, er imidlertid reelt. Sitatene, som i posisjoneringsanalysen beskrives som talehandlinger, består av ytringer notert under observasjonene.

\section{Posisjonene i det tverrfaglige samarbeidet}

Som nevnt er analysen orientert mot å finne ut hva som ligger bak spenninger i et tverrfaglig samarbeid. Det analytiske redskapet er hentet fra posisjoneringsteori, som beskriver relasjoner, samspill og meningsdannelse i konkrete sosiale episoder (Harre \& Moghaddam, 2012). Møtene i det tverrfaglige samarbeidet rundt Maria er de sosiale episodene som 
analyseres, og det er deltagernes talehandlinger som brukes for å beskrive deres posisjoner og posisjoneringsdynamikken.

Analysen tar utgangspunkt i deltagernes posisjon og meninger om det som samarbeidet dreier seg om. En posisjoneringsanalyse starter med å beskrive en «rolleliste» over alle aktørene i form av posisjon og deres talehandlinger. Hver av deltagerne kommer til de tverrfaglige møtene med en oppfatning av hva dette handler om, og hva som er deres sentrale oppgave - en slags storyline. Sammen med forventningene følger en bevisst eller ubevisst forståelse av egen rolle og posisjon. Deltagerne er bundet av ulike lovverk og mandater, og de forfekter verdier og oppfatninger av egne og andres ansvarsområder. Tabell 1 gir et bilde av «rollelisten» og det som utspilte seg på møtene. Det varierte hvem som var til stede. Avdelingsoverlegen deltok for eksempel aldri, men hennes perspektiver ble fremført av avdelingssykepleieren.

Tabell 1. Deltagernes posisjoner.

\begin{tabular}{|c|c|c|c|}
\hline Deltager & Storyline & Posisjon & Talehandling \\
\hline $\begin{array}{l}\text { Avdelingsoverlege, } \\
\text { psykisk helsevern }\end{array}$ & $\begin{array}{l}\text { Vurdering og } \\
\text { behandlingen av } \\
\text { Marias psykiske } \\
\text { lidelse. }\end{array}$ & $\begin{array}{l}\text { Høy status i } \\
\text { behandlingshierarkiet } \\
\text { og stor } \\
\text { definisjonsmakt. Stort } \\
\text { ansvar, sterke formelle } \\
\text { rettigheter. }\end{array}$ & $\begin{array}{l}\text { Graviditeten og } \\
\text { hva som skal skje } \\
\text { med barnet, er ikke } \\
\text { vårt ansvar og skal } \\
\text { heller ikke ha fokus i } \\
\text { behandlingen. }\end{array}$ \\
\hline $\begin{array}{l}\text { Avdelingssykepleier, } \\
\text { psykisk helsevern }\end{array}$ & $\begin{array}{l}\text { Trekkes mellom } \\
\text { legens anvisninger, } \\
\text { egne vurderinger og } \\
\text { Marias ønsker og } \\
\text { behov. }\end{array}$ & $\begin{array}{l}\text { Underordnet og } \\
\text { delegert ansvar for å } \\
\text { gjennomføre legens } \\
\text { behandlingsplan. } \\
\text { Middels status } \\
\text { i kraft av } \\
\text { spesialisthelsetjeneste. }\end{array}$ & $\begin{array}{l}\text { Vi skal ikke snakke } \\
\text { om det, men det er } \\
\text { vanskelig å ignorere } \\
\text { den voksende magen, } \\
\text { barnevogna og } \\
\text { babyklærne. }\end{array}$ \\
\hline $\begin{array}{l}\text { Tjenesteområdesjef, } \\
\text { rus/psykisk helse, } \\
\text { kommune }\end{array}$ & $\begin{array}{l}\text { Sørge for at de } \\
\text { kommunale } \\
\text { tjenestene henger } \\
\text { sammen og gjør en } \\
\text { god jobb. }\end{array}$ & $\begin{array}{l}\text { Stort formelt ansvar } \\
\text { med ledermyndighet } \\
\text { til å instruere. } \\
\text { Høy status i } \\
\text { kommunen, middels i } \\
\text { helsesystemet. }\end{array}$ & $\begin{array}{l}\text { Jeg har gitt beskjed om } \\
\text { at våre ulike tjenester } \\
\text { skal stille på disse } \\
\text { møtene. }\end{array}$ \\
\hline $\begin{array}{l}\text { Sosialarbeider, } \\
\text { rus/psykisk helse, } \\
\text { kommune }\end{array}$ & $\begin{array}{l}\text { Den unnselige, men- } \\
\text { for Maria - viktigste } \\
\text { hjelperen. Den som } \\
\text { har det fyldigste } \\
\text { bildet av Marias } \\
\text { fungering. }\end{array}$ & $\begin{array}{l}\text { Sentral for } \\
\text { gjennomføring, } \\
\text { viktigst for pasient, } \\
\text { men med liten } \\
\text { makt og innflytelse } \\
\text { over innhold og } \\
\text { samhandling. }\end{array}$ & $\begin{array}{l}\text { Jeg gjør mitt beste } \\
\text { for å fylle alles } \\
\text { forventninger, men er } \\
\text { frustrert over at ingen } \\
\text { lytter til meg. }\end{array}$ \\
\hline
\end{tabular}

(Fortsetter) 
Tabell 1. (Fortsettelse)

\begin{tabular}{|c|c|c|c|}
\hline Deltager & Storyline & Posisjon & Talehandling \\
\hline Fastlege & $\begin{array}{l}\text { Det helserelaterte } \\
\text { «navet» med god } \\
\text { kjennskap til Marias } \\
\text { utfordringer. }\end{array}$ & $\begin{array}{l}\text { Betydelig ansvar } \\
\text { og myndighet, og } \\
\text { vedkommendes } \\
\text { deltagelse verdsettes } \\
\text { av de andre. Høy } \\
\text { formell status. }\end{array}$ & $\begin{array}{l}\text { Jeg tror ikke jeg er } \\
\text { den som skal melde } \\
\text { bekymringene. Det } \\
\text { er viktig at Maria } \\
\text { beholder tilliten til } \\
\text { meg. }\end{array}$ \\
\hline Terapeut, BUP & $\begin{array}{l}\text { Den } \\
\text { samspillsorienterte } \\
\text { hjelperen som } \\
\text { skal stimulere } \\
\text { foreldreskap og } \\
\text { forberedelser til } \\
\text { barnets komme. }\end{array}$ & $\begin{array}{l}\text { Behandlingsansvarlig } \\
\text { for mor og barn } \\
\text { og innehaver av } \\
\text { spesialkunnskap om } \\
\text { utvikling og risiko. }\end{array}$ & $\begin{array}{l}\text { Hun fungerer ganske } \\
\text { bra når hun er hos } \\
\text { meg. Men jeg er } \\
\text { usikker på om vi skal } \\
\text { jobbe med tilknytning } \\
\text { og foreldreskap hvis } \\
\text { hun mister barnet. }\end{array}$ \\
\hline Helsesøster & $\begin{array}{l}\text { Nybakte mødres } \\
\text { og barns sentrale } \\
\text { fagstøtte og rådgiver. }\end{array}$ & $\begin{array}{l}\text { Sitter «på vent» } \\
\text { gjennom graviditeten } \\
\text { med liten påvirkning. }\end{array}$ & $\begin{array}{l}\text { Det er fint å bli kjent } \\
\text { med problematikken, } \\
\text { slik at jeg kan hjelpe } \\
\text { bedre etter fodselen. }\end{array}$ \\
\hline $\begin{array}{l}\text { Jordmor i } \\
\text { kommunen }\end{array}$ & $\begin{array}{l}\text { Den sentrale } \\
\text { ansvarlige for } \\
\text { oppfølging av } \\
\text { graviditeten. Fokus } \\
\text { på somatikk. }\end{array}$ & $\begin{array}{l}\text { Respekt og myndighet } \\
\text { som jordmor, men } \\
\text { i konkurranse med } \\
\text { sykehusets jordmor. }\end{array}$ & $\begin{array}{l}\text { Jeg er litt usikker } \\
\text { på min rolle nå når } \\
\text { sykehuset er koblet på. }\end{array}$ \\
\hline $\begin{array}{l}\text { Jordmor på } \\
\text { fødeavdeling }\end{array}$ & $\begin{array}{l}\text { Den erfarne på } \\
\text { risikosvangerskap. }\end{array}$ & $\begin{array}{l}\text { Faglig tyngde, formell } \\
\text { og uformell innflytelse. }\end{array}$ & $\begin{array}{l}\text { Ja, vi skal tenke på } \\
\text { risiko, men Maria skal } \\
\text { også behandles som en } \\
\text { normal fødekvinne. }\end{array}$ \\
\hline Barneverntjenesten & $\begin{array}{l}\text { Støttetjeneste for } \\
\text { barnets beskyttere og } \\
\text { utsatte foreldre - en } \\
\text { krevende spagat. }\end{array}$ & $\begin{array}{l}\text { Stor formell makt og } \\
\text { ansvar. Håndterer } \\
\text { andres bekymring, } \\
\text { men relativt lav status } \\
\text { i hjelperhierarkiet. }\end{array}$ & $\begin{array}{l}\text { Vi er de eneste som } \\
\text { kun har barnets beste } \\
\text { for øye. Det er lett for } \\
\text { dere andre å velge å } \\
\text { støtte mor og slippe } \\
\text { ubehaget med å dele } \\
\text { deres bekymringer. }\end{array}$ \\
\hline Prosessveileder & $\begin{array}{l}\text { Fremme de ulike } \\
\text { vurderinger, støtte } \\
\text { fremdrift og komme } \\
\text { frem til en felles } \\
\text { forståelse. }\end{array}$ & $\begin{array}{l}\text { Lav formell makt, } \\
\text { men ansvarlig for } \\
\text { samarbeidsprosess. }\end{array}$ & $\begin{array}{l}\text { Kan alle formulere } \\
\text { hvordan dere, her og } \\
\text { nå, vurderer Marias } \\
\text { kapasitet til å ta seg av } \\
\text { et nyfødt barn? }\end{array}$ \\
\hline
\end{tabular}

Listen over involverte fagfolk og beskrivelsen av Marias situasjon illustrerer kompleksiteten i tematikken foreldrestøtte og spedbarnevern. Bak den enkelte fagpersons ytringer spiller også vedkommendes personlige og fagetiske verdier en rolle. 


\section{Verdikonflikter, dilemmaer og spenninger i samarbeidet}

Legen skal først og fremst ikke gjøre skade, men gjøre godt for sin primærpasient, Maria. Overlegens ytringer om ikke å tematisere graviditeten og barnet i magen kan være begrunnet i ulike forhold. Hun har muligens en unik klinisk erfaring med Marias lidelse, eller det kan være manglende erfaring med lidelsen i kombinasjon med graviditet. Det kan også handle om en restriktiv fortolkning av eget mandat. Fastlegen, med sitt allmennlegemandat, er bekymret for både Maria og barnet. Men verdien av en god pasientrelasjon er sterk, og fastlegen ønsker først at andre tjenester melder til barnevernet for å verne om pasientrelasjonen.

Avdelingssykepleieren er forpliktet til å følge overlegen, men egne kvinne- og morserfaringer vekkes i møte med gravide. I tillegg til sitt fag har hun personlig erfaringskunnskap og verdier. Hun føler at det er vanskelig å ignorere Marias voksende mage, og hun mener trolig at en gravid trenger støtte av andre trygge og erfarne mødre. Både fastlegen og avdelingssykepleier tumler med indre verdivalg, dilemmaer som er ofte er forbundet med spedbarnevern og foreldrestøtte. Verdien av sosial støtte og et kvinnefelleskap kan beskrives som nettopp en verdi hvis positive betydning for foreldreskapet også er forskningsmessig dokumentert (Stern, 1995).

Helsesøster og jordmødrene er også del av en medisinsk diskurs eller storyline, men deres ansvar og omsorg omfatter både mor og barn. Det samme gjelder BUP, hvis posisjon beveger seg mot en psykososial tradisjon sammen med kommunens sosialtjeneste. BUPs dilemma står mellom verdien av å støtte og behandle foreldre i en livsfase hvor trygghet, oppmuntring og tro på forelder-barn-prosjektet hører med. Imidlertid er barnet BUPs primære ansvar, og faglig veier verdien av å beskytte og støtte barnets utvikling tyngst.

Motpolene barnevern og foreldrevern brukes ofte retorisk for å fortelle eller kritisere hvilken side man tar i verdikonflikt om barnevern. De fleste aktørene har begge perspektiver, men fag og mandat som vektlegger dem ulikt. Også personlige erfaringer og verdier spiller inn, mer eller mindre synlig. Barnevernet står i verdispagat mellom foreldrearbeid og 
familiestøtte på den ene siden og inngrep i familien for å trygge barnets helse og utvikling på den andre. Tidligere menneskerettighetsdommer Hillestad Thune mener at dobbeltrollen som hjelper og kontrollør med stor makt er umulig og bør deles i to separate tjenester (Nordgaard, 2018).

\section{En dynamisk posisjonering}

I løpet av prosessen steg og sank spenningene mellom de ulike tjenestene. Helse- og omsorgstjenestene vegret seg for å uttrykke sine bekymringer klart og tydelig til barnevernet, men de forventet likevel at barnevernet skulle ta grep og bestemme om mor skulle få beholde barnet eller ei. Barnevernet visste at samarbeidspartene var bekymret, og man ventet på klar tale for å underbygge sine vurderinger og konklusjoner. Det hersket ulike meninger om hvorvidt Maria burde informeres om en beslutning om omsorgsovertakelse på forhånd. På bakgrunn av sorteringen av deltagernes posisjoner og ytringer foreslår jeg at det eksisterer tre parallelle storylines - en medisinsk, en psykososial og en barnevernsstoryline. Tabell 2 oppsummerer og viser hvordan disse tre posisjonerer mor og det kommende barnet ulikt.

Tabell 2. Tre ulike storylines.

\begin{tabular}{|l|l|l|l|}
\hline Storyline & Fag og tjenester & Marias posisjon & Barnets posisjon \\
\hline $\begin{array}{l}\text { Den medisinske - } \\
\text { behandle en lidelse }\end{array}$ & $\begin{array}{l}\text { Fastlege, spesialisert } \\
\text { psykisk helsevern for } \\
\text { voksne }\end{array}$ & $\begin{array}{l}\text { Pasient - graviditet } \\
\text { og morsrolle tonet } \\
\text { ned. }\end{array}$ & $\begin{array}{l}\text { Usynlig, irrelevant og } \\
\text { kompliserende. }\end{array}$ \\
\hline $\begin{array}{l}\text { Den psykososiale - } \\
\text { støtte og behandle } \\
\text { individ og relasjoner }\end{array}$ & $\begin{array}{l}\text { NAV, BUP sped- og } \\
\text { småbarnsteam }\end{array}$ & $\begin{array}{l}\text { Gravid, del av familie, } \\
\text { potensielt kompetent } \\
\text { til omsorg. }\end{array}$ & $\begin{array}{l}\text { Synlig og mål } \\
\text { for tidlig innsats } \\
\text { sammen med mor. } \\
\text { Del av en dyade. }\end{array}$ \\
\hline $\begin{array}{l}\text { Barnevern - beskytte } \\
\text { barnet, et «føre var»- } \\
\text { prinsipp }\end{array}$ & Barneverntjenesten & $\begin{array}{l}\text { Mor, potensiell } \\
\text { trussel mot barnet. } \\
\text { Pasientrolle tones } \\
\text { ned. }\end{array}$ & $\begin{array}{l}\text { Synlig, med sterkt } \\
\text { beskyttelsesbehov. } \\
\text { Barnets beste } \\
\text { målestokk for tiltak. }\end{array}$ \\
\hline
\end{tabular}

\section{Konflikt mellom behandling og kontroll}

Neste steg i analysen identifiserer hovedkonflikten, som her ser ut til å være helse- og omsorgstjenestene versus barneverntjenesten. Tabell 3 
viser hvordan fagfolkene posisjonerer seg selv og dermed også den andre parten. I likhet med funnene i barnevoldsutvalgets rapport (NOU, 2017: 12) hadde tjenestene innledningsvis uklare forventninger til hva egen og andres tjeneste kunne eller burde bidra med i samarbeidet, og spenningsnivået på møtene steg.

Tabell 3. Helse og omsorg versus barnevern.

\begin{tabular}{|l|l|l|l|}
\hline \multicolumn{2}{|c|}{ Helse- og omsorgstjenestene } & \multicolumn{2}{c|}{ Barneverntjenesten } \\
\hline Storyline & Posisjonering & Storyline & Posisjonering \\
\hline $\begin{array}{l}\text { Hjelpe og behandle } \\
\text { Maria og beskytte } \\
\text { den terapeutiske } \\
\text { alliansen. }\end{array}$ & $\begin{array}{l}\text { Posisjonerer seg } \\
\text { selv som «de gode» } \\
\text { hjelperne. }\end{array}$ & $\begin{array}{l}\text { Handle, gripe inn for } \\
\text { å beskytte barnet. }\end{array}$ & $\begin{array}{l}\text { Posisjonerer seg selv } \\
\text { som de ansvarlige } \\
\text { hjelperne. }\end{array}$ \\
\hline $\begin{array}{l}\text { Forventer at } \\
\text { Barneverntjenesten } \\
\text { skal gjennomføre } \\
\text { nødvendige inngrep, } \\
\text { uten å «skitne» egne } \\
\text { hender. }\end{array}$ & $\begin{array}{l}\text { Posisjonerer } \\
\text { Barneverntjenesten den inngripende } \\
\text { og potensielt } \\
\text { «farlige» part. }\end{array}$ & $\begin{array}{l}\text { Forventer at helse- og } \\
\text { omsorgsarbeiderne } \\
\text { melder og formidler } \\
\text { sin bekymring. }\end{array}$ & $\begin{array}{l}\text { Posisjonerer } \\
\text { helse- og } \\
\text { omsorgsarbeiderne } \\
\text { som uansvarlige og } \\
\text { feige. }\end{array}$ \\
\hline
\end{tabular}

Når posisjoneringsanalysen handler om en konflikt, vil man også søke etter grep som kan forene eller bringe partene nærmere hverandre. Dette kaller Harré og Slocum (2003) for en diskursiv bro. Det handler da om å lete etter hendelser eller intervensjoner med potensial til å dempe konflikt og spenning. Skjer det noe som får partene til se saken i nytt lys, noe som bidrar til felles forståelse eller omorganisering av posisjoner? I samarbeidet rundt Maria intervenerte prosessveileder ved å be alle gi uttrykk for sine vurderinger av mors tilstand, og om de så det som sannsynlig at hun kunne ta seg av sitt nyfødte barn. Det var overveiende enighet om at det var usannsynlig og uforsvarlig. Det ble åpent diskutert hvordan fastlegens tydelighet overfor Maria ville spille inn på lege-pasient-relasjonen. Drøftingen synliggjorde at det like gjerne kunne oppstå mistillit dersom legen ikke formidlet sine bekymringer.

Det var fortsatt uenigheter om hvorvidt Maria skulle forberedes på en omsorgsovertakelse eller om det var best - for henne og barnet - å vente med å forkynne beslutningen til etter fødsel. Barnevernet bekymret seg for om Maria kunne finne på å flytte eller stikke av. De ansatte 
i barnevernet var også bekymret for at det ville utsette fosteret for skadelig stress. Etter drøfting og refleksjoner med utgangspunkt i hvert sitt faglige perspektiv samlet gruppen seg om at Maria burde gis anledning til å forberede seg. Omsorgsovertakelsen som alle i denne fasen var enige i at burde skje, ble sammenlignet med andre store og alvorlige livshendelser og med kunnskap som viser at åpenhet og forberedelse er nødvendig for å takle og tåle det som kommer. Den tverrfaglige gruppen stilte seg bak barnevernets beslutning om å informere Maria om barnevernets beslutning i god tid før fødselen. Teamet fortsatte oppfølgingen av Maria, og man ble vitne til hvordan hun forberedte seg frem mot fødselen. Alle detaljer ved omsorgsovertakelsen ble planlagt i samråd med Maria. Hun fikk innflytelse på hendelsesforløpet rundt separasjonen, på tiden hun fikk sammen med barnet, og på hvem som skulle være til stede under omsorgsovertakelsen. Hun var på forhånd kjent med innholdet i barnevernets vedtak, og hun hadde forberedt en innholdsrik velkomst- og avskjedspakke til barnet sitt. Barselpersonalet beskrev denne planlagte omsorgsovertakelsen som rolig, rørende og verdig.

\section{Avsluttende kommentar}

Fortellingen om gravide Maria synliggjør spenninger, verdikonflikter og løsninger og illustrerer én av flere mulige arbeidsprosesser. Problemstillingene, spenningene og dilemmaene rundt vurderingene og beslutningene antas imidlertid å være generelle og velkjente for både praksisfeltet og forskningen. Det er flere innfallsvinkler til å forstå og forklare disse spenningene. I dette kapitlet har jeg brukt posisjoneringsteori for å få tak i underliggende årsaker, som hierarki, ansvar, makt, verdier og faglig og juridisk mandat.

Barnevoldsutvalget (NOU, 2017: 12) hevder at barnevernets mekanismer for samarbeid og samordning er for svake på flere nivåer, og at rolleog ansvarsfordeling mellom tjenestene ofte var uklare og utfordrende. Utvalget viser til at det «... i løpet av 2017 skal etableres et tilbud om veiledningsbistand til kommuner med høy risiko for svikt i tjenestetilbudet. Veiledningen skal skje i form av egne veiledningsteam.... Formålet med 
veiledningen er å få på plass systemer og arbeidsformer som møter utfordringene tjenestene står overfor» (NOU, 2017: 12, del 8.6.1).

Dalland (2017) foreslår en reform rundt barne-, foreldre- og familievern som kan løse opp eksisterende dilemmaer og haltende tverrfaglig samarbeid, og som peker i samme retning som barnevoldsutvalget, med opprettelse av regionale tverretatlige innsatsteam med spesialkompetanse. Hun forutsetter at brukernes erfaringer må være med på å forme et slikt tilbud. I likhet med de ovennevnte rapporter og styringsdokumenter understreker praksisanbefalinger for psykisk helsevern i perinalperioden, det vil si tiden før, under og etter fødsel, betydningen av et godt tverrprofesjonelt samarbeid (Brockington, Butterworth \& GlangeaudFreudenthal, 2017).

Posisjoneringsanalysen viser at det ikke bare handler om risiko for svikt i de kommunale tjenestene, men at spenninger oppstår som resultat av ulike posisjoner og faglige overbevisninger på tvers av tjenester og nivåer. Hele det tverrfaglige feltet utfordres til bedre teamarbeid med behørig respekt for hverandres fag og ansvarsområder. I kapittel 9 i denne boken (Söderström \& Sandvig, 2020) beskrives tverrfaglig simuleringstrening som en metodikk for bedre å forstå hverandres fag og mandat gjennom å øve sammen i virkelighetsnære scenarioer.

I samarbeidet rundt Maria bidro både det langsiktige perspektivet, samordningsgrepet med koordinator og en prosessveileder til at deltagerne fikk drøftet fra ulike perspektiver, og de kom frem til en felles oppfatning om hva som var den beste beslutningen. Selv om utfallet i denne saken ikke var det sentrale, er det grunn til å spørre om selve samarbeidsmodellen bidro til denne verdige, planlagte omsorgsovertakelsen med samtykke fra Maria. Hun fikk forberede seg, med bedre mulighet til å ta vare på seg selv og til å være den beste moren hun kunne på det gitte tidspunktet. Hun deltok i planleggingen av hvordan adskillelsen skulle skje. Hun beholdt tilliten til sine hjelpere, og samarbeidsrelasjonene mellom de profesjonelle ble styrket. Verdien av åpen refleksjon mellom profesjonelle og av å være informert og involvert i avgjørelser av dyp eksistensiell betydning for individet samlet en sprikende tverrfaglighet og gjorde trolig både Maria og de profesjonelle bedre rustet for fremtiden. 


\section{Litteratur}

Barnekonvensjonen (1989). FNs konvensjon om barnets rettigheter. Hentet 5.12.2019 fra https://www.unicef.no/barnekonvensjonen

Barne- og familiedepartementet. (1992). Om lov om barneverntjenester (barnevernloven) (Ot.prp. nr. 44 (1991-1992). Hentet fra https://www.stortinget. no/no/Saker-og-publikasjoner/Stortingsforhandlinger/Lesevisning/? $\mathrm{p}=1991-92 \&$ paid $=4$ \&wid $=$ c\&psid $=$ DIVL $_{312}$

Barnevernloven. (1992). Lov om barneverntjenester (LOV-1992-07-17-100). Hentet fra https://lovdata.no/dokument/NL/lov/1992-07-17-100

Broadhurst, K., Alrouh, B., Yeend, E., Harwin, J., Shaw, M., Pilling, M., ... Kershaw, S. (2015). Connecting events in time to identify a hidden population: Birth mothers and their children in recurrent care proceedings in England. British Journal of Social Work, 45(8), 2241-226o. https://doi.org/10.1093/bjsw/bcv130

Broadhurst, K., Shaw, M., Kershaw, S., Harwin, J., Alrouh, B., Mason, C. \& Pilling, M. (2015). Vulnerable birth mothers and repeat losses of infants to public care: Is targeted reproductive health care ethically defensible? Journal of Social Welfare \& Family Law, 37(1), 87-98. http://dx.doi.org/10.1080/09649069.2015.998007

Brockington, I., Butterworth, R. \& Glangeaud-Freudenthal, N. (2017). An international position paper on mother-infant (perinatal) mental health, with guidelines for clinical practice. Archives of Women's Mental Health, 2o(1), 113-120. https://doi.org/10.1007/s00737-016-0684-7

Bufdir. (2019). Utredning av kompetansehevingstiltak i barnevernet. Hentet fra https://www.bufdir.no/Bibliotek/Dokumentside/?docId=BUFoooo5020

Bullough, R. V. \& Draper, R. J. (2004). Making sense of a failed triad: Mentors, university supervisors, and positioning theory. Journal of Teacher Education, 55(5), 407-420. https://doi.org/10.1177/0022487104269804

Clifford, G. (2015). Minst hjelp til dem som trenger det mest? Sluttrapport fra forsknings- og utviklingsprosjektet «Det nye barnevernet» (NF rapport nr. 6/2015). Bodø: Nordlandsforskning.

Cox, P. (2012). Marginalized mothers, reproductive autonomy, and repeat losses to care. Journal of Law and Society, 39, 541-561. https//:doi.org/10.1111/j.1467-6478. 2012.00599.x

Dalland, H. (2017, 15. februar). Vern barnet, ikke foreldrene. Bergens Tidende,. Hentet fra https://www.bt.no/btmeninger/debatt/i/WPLQd/vern-barnet-ikke-foreldrene

Dyrhaug, T. (2019). Personlig e-postkommunikasjon med statistikkavdeling i Statistisk sentralbyrå (SSB), mottatt den 12.07.2019. https://www.ssb.no/barneverng

Everitt, L., Fenwick, J. \& Homer, C. S. E. (2015). Midwives experiences of removal of a newborn baby in New South Wales, Australia: Being in the 'head' and 'heart' space. Women and Birth, 28(2), 95-100. https://doi.org/10.1016/j. wombi.2015.01.004 
Freel, M. (2010). Baby K's unlawful removal: Practice issues in the emergency protection of children. Child Abuse Review, 19(3), 158-168. https://doi.org/10.1002/ car.1107

Gording Stang, E. (2019, 29. september). Podcast Desse dagar. Hentet fra https://radio. nrk.no/podkast/desse_dagar/nrkno-poddkast-26631-159503-290920191000oo

Grant, T., Huggins, J., Graham, C. J., Ernst, C., Whitney, N. \& Wilson, D. (2014). Maternal substance abuse and disrupted parenting: Distinguishing mothers who keep their children from those who do not. Children and Youth Services Review, $33(11), 2176-2185$.

Hansen, A. (2019, 3. juli). Sjokkangrep mot norsk barnevern. Dagbladet. Hentet fra https://www.dagbladet.no/nyheter/sjokkangrep-mot-norsk-barnevern/71363829

Harré, R. \& Moghaddam, F. M. (2012). Psychology for the third millennium: Integrating cultural and neuroscience perspectives. London: SAGE Publications.

Harré, R. \& Slocum, N. (2003). Disputes as complex social events. Common Knowledge, 9(1), 100.

Helland, T. (2019). Care order cases in the European Court of Human Rights. Parents' vs. children's rights (Doktoravhandling). Universitet i Bergen, Bergen.

Helsepersonelloven. (1999). Lov om helsepersonell m.v. (LOV-1999-07-02-64). Hentet fra https://lovdata.no/dokument/NL/lov/1999-07-02-64

Jacobsen, M. (2019, o6. august). [Statistikk om akuttvedtak og omsorgsovertakelse av nyfødt barn]. Personlig epostkommunikasjon med Fylkesnemndenes sentralenhet. ref. 19/00290-1

Jakobsen, S. E. (2018, 7. februar). Hva skal til for at barnevernet tar et nyfødt barn fra mor? Forskning.no. Hentet fra https://forskning.no/velferdsstat-barn-og-ungdomny/hva-skal-til-for-at-barnevernet-tar-et-nyfodt-barn-fra-mor/290709

Jensen, I., Fredrikstad, A., Saabye, S. \& Haugen, P. (2016). Barnevernet tar tre ganger så mange nyfødte barn. Hentet fra https://www.tv2.no/a/8219203/

Johansen, I. (2014). Turnover i det kommunale barnevernet. Oslo: Statistisk sentralbyrå. Hentet fra https://www.ssb.no/arbeid-og-lonn/artikler-og-publikasjoner/_ attachment/175497?_ts=145d565fod8

Helse- og omsorgstjenesteloven. (2011). Lov om kommunale helse- og omsorgstjenester m.m. (LOV-2011-06-24-30). Hentet fra https://lovdata.no/ dokument/NL/lov/2011-06-24-30

Marsh, W., Robinson, A., Leamon, J. \& Shawe, J. (2014). Removing babies from mothers at birth: Midwives' experiences. British Journal of Midwifery, 22(9), 620-624.

Menneskerettsloven. (1999). Vedlegg 2. Den europeiske menneskerettskonvensjon med protokoller (norsk oversettelse) (LOV-1999-05-21-30). Hentet fra https:// lovdata.no/dokument/NL/lov/1999-05-21 30/emkn/ARTIKKEL_8\#emkn/ ARTIKKEL_8. 
Nordby, H. (2017). Konflikthåndtering for ledere. Oslo: Gyldendal akademisk.

Nordgaard, T.-B. (2018). Tidligere menneskerettighetsdommer slår alarm: - Totalt fravær av rettssikkerhet i barnevernet. Norge i dag. Hentet fra https://idag.no/ totalt-fravar-av-rettssikkerhet-i-barnevernet/19.28084

NOU 2016: 16 (2016). Ny barnevernlov - Sikring av barnets rett til omsorg og beskyttelse. Hentet fra https://www.regjeringen.no/no/dokumenter/nou-2016-16/ id 2512881/

NOU 2017: 12. (2017). Svikt og svik - Gjennomgang av saker hvor barn har voert utsatt for vold, seksuelle overgrep og omsorgssvikt. Hentet fra https://www. regjeringen.no/contentassets/a44ef6e251cd443396588483e97402ab/no/pdfs/ nou2017201700120oodddpdfs.pdf

Odland, A. M. (2018, 8. mai). Familievernet: - Å ta vare på foreldre som mister omsorgen for barn har vært et forsømt område. Nå gjør vi noe med det. FriFagbevegelse. Hentet fra https://frifagbevegelse.no/forside/familievernet--a-tavare-pa-foreldre-som-mister-omsorgen-for-barn-har-vart-et-forsomt-omradena-gjor-vi-noe-med-det-6.158.546413.490888437e

Pasient- og brukerrettighetsloven. (1999). Lov om pasient- og brukerrettigheter (LOV-1999-07-02-63). Hentet fra https://lovdata.no/dokument/NL/lov/199907-02-63.

Politiet. (2019). Alvorlig vold not små barn. Hentet fra https://www.politiet.no/ globalassets/o4-aktuelt-tall-og-fakta/vold-mot-barn/alvorlig-vold-mot-barn.pdf

Rognum, T. O. (2016, 6. september). Flere barn dør av mishandling enn i trafikkulykker. Aftenposten. Hentet fra https://www.aftenposten.no/meninger/ kronikk/i/8W26x/flere-barn-doer-av-mishandling-enn-i-trafikkulykker-torleivole-rognum

Sandberg, K. (2005). Akuttplassering av spedbarn og menneskerettigheter. Tidsskrift for familierett, arverett og barnevernrettslige spørsmål, 3(2).

Skogstrøm, L. (2019, 19. november). 30-40 nyfødte tas fra foreldre hvert år. Svært få når frem med å klage på akuttplasseringene. Aftenposten. Hentet fra https:// www.aftenposten.no/norge/i/mRx9Og/3040-nyfoedte-tas-fra-foreldre-hvert-aarsvaert-faa-naar-frem-med-aa-klage-paa-akuttplasseringene

Slettebø, T., Briseid, K., Brodtkorb, E., Skjeggestad, E., Sverdrup, S. \& Sørensen, T. (2019). Godt nok barnevern? Forståelser av forsvarlighet og internkontroll $i$ den kommunale barnevernstjenesten. Hentet fra https://vid.brage.unit.no/ vid-xmlui/bitstream/handle/11250/2593471/Godt_nok_barnevern_Forstaelser_ av_forsvarlighet_og_internkontroll_i_den_kommunale_barneverntjenesten. pdf? sequence $=1$ \&isAllowed $=y$

Stern, D. N. (1995). The motherhood constellation: A unified view of parent-infant psychotherapy. New York: Basic Books. 
Söderström, K. (2011). Tidlig intervensjon overfor små barn i psykososial risiko. I S. Straand (Red.), Samhandling som omsorg: tverrfaglig psykososialt arbeid med barn og unge (s. 158-175). Oslo: Kommuneforlaget.

Søvig, K. H. (2019). Avgjørelser fra EMD i saker om vern av privat- og familieliv fra 2018. Tidsskrift for familierett, arverett og barnevernrettslige spørsmål, (3), 227-246. https://doi.org/10.18261/issn.0809-9553-2019-03-03

Tirado, F. \& Gálvez, A. (2007). Positioning theory and discourse analysis: Some tools for social interaction analysis. Forum: Qualitative Social Research, 8(2).

Witoszek, N., Totland, T., Nwosu, E., Thune, G. H. \& Salvesen, E. C. (2015, 10. juni). Bekymringsmelding om barnevernet. Aftenposten. Hentet fra https://www. aftenposten.no/norge/i/ME5E/bekymringsmelding-om-barnevernet 



\title{
Familieverdier i spill: Ungdoms erfaringer med barneverntjenesten når mor eller far har rusproblemer eller alvorlig psykiske helseproblemer
}

\section{Astrid Halsa}

Førsteamanuensis, Høgskolen i Innlandet

\begin{abstract}
This chapter reports on a qualitative study with 32 young people who grew up in families where there were substance use or serious mental health problems. The aim is to explore young people's accounts of experiences with child protection services (CPS). The young people had for years been worried about their parents and experienced emotional abuse, stigma, secrecy, anxiety and role reversal. When they understood what was wrong with their parents, they worked hard to protect themselves and their families from unwanted intrusion from public services. They report a reluctance to disclose their situation, and a fear of being taken into care when they were in contact with CPS. To disclose meant the same as letting your parents down. All the families had been in contact with CPS, but the participants mostly had negative accounts of the services they and their families had received. These findings are discussed in light of the emotional and symbolic significance of family ties and embeddedness in family.
\end{abstract}

Keywords: parental substance use and mental health problems, young people's accounts on child protection, the symbolic meaning of families

Sitering av denne artikkelen: Halsa, A. (2020). Familieverdier i spill: Ungdoms erfaringer med barneverntjenesten når mor eller far har rusproblemer eller alvorlig psykiske helseproblemer. I H. Nordby \& A. Halsa (Red.), Verdier i barnevern (Kap. 8, s. 153-172). Oslo: Cappelen Damm Akademisk. https://doi. org/10.23865/noasp.103.ch8

Lisens: CC BY-ND 4.0 


\section{Innledning}

Barneverntjenesten har en viktig funksjon når det gjelder å hjelpe barn og unge som vokser opp med store familiære belastninger. Når foreldrene er rusavhengige eller har alvorlige og langvarige psykiske helseproblemer, har ungdom behov for hjelp og sosial støtte. Samtidig vet vi at spesielt foreldreskap og rusavhengighet, men også foreldreskap koblet med psykiske helseproblemer, er forbundet med kulturell skam og problemer som foreldre og barn ønsker å holde skjult for omgivelsene (Backett-Milburn, Wilson, Bancroft \& Cunningham-Burley, 2008; Delås, 2015; Halsa, 2018; Werner \& Malterud, 2016). Ofte er mors eller fars rusproblemer eller psykiske helseproblemer en familiehemmelighet som det ikke snakkes om (Halsa, 2008; Wangensteen, Bramness \& Halsa, 2018). I et forskningsprosjekt jeg deltok i, har vi intervjuet 32 ungdommer og unge voksne om deres erfaring med å vokse opp i slike belastede omsorgssituasjoner (Mosaikkprosjektet). ${ }^{1}$ Felles i nesten alle historiene til disse unge eller unge voksne er at de har levd årevis med bekymring for sine foreldre. Erfaringene deres spenner fra alvorlig omsorgssvikt, med mødre som forsvinner hjemmefra i ukesvis, hyppige partnerbytter og voldelige stefedre, til mindre alvorlige, men likevel belastende omsorgssituasjoner. Mange forteller at de selv etter hvert utviklet egne problemer - som at de var klassens klovn eller skulket skolen - og ulike typer psykiske problemer (Kommisrud, Söderström, Halsaa \& Halsa 2019; Söderström, 2017; Wangensteen et al., 2018).

I dette kapitlet vil jeg løfte frem disse ungdommenes erfaringer med barneverntjenesten. Barnevernet har et tydelig mandat knyttet til å sikre at barn og unge i belastede familier får god omsorg og trygge oppvekstsvilkår ved å tilby riktig hjelp til rett tid. Sentrale verdier i barnevernets lovgrunnlag er barns rett til å bli hørt, involvert og delta i spørsmål om eget liv. Dette er også behørig slått fast i FNs konvensjon om barns rettigheter og nedfelt i Grunnlovens paragraf 104. Likevel opplever mange

1 Mosaikkprosjektet var finansiert av Norges forskningsråd og hadde den engelske tittelen «Children living in families with parental illness and/or substance abuse: Participation, Competence Development and Social support». 
ungdommer i slike livssituasjoner at de verken blir sett, hørt eller hjulpet på måter som de opplever som nyttige (Kufås, Faugli \& Weimand, 2015; Moore, McArthur \& Noble-Carr, 2011; Sundfær, 2012; Templeton, Novak \& Wall, 2011). Barnevernproffene har gitt mange vitnemål om at barneverntjenesten kom for sent inn - og om manglende informasjon og innflytelse (Forandringsfabrikken, 2017).

Hvordan barn og unge snakker om sitt møte med barneverntjenesten, er selvsagt avhengig av når og i hvilken sammenheng spørsmålene blir stilt. I vår undersøkelse var vi opptatt av at ungdommene skulle fortelle om sine oppveksthistorier både innenfor familien, på skolen og blant jevnaldrende. Vi ønsket å høre historier om hva de hadde opplevd som vanskelig, og særlig om hva som hadde vært hjelpsomt og sosialt støttende. Barneverntjenesten var bare én blant flere hjelpeinstanser som var i kontakt med familiene. De fleste fortalte sine historier i retrospektivt lys og forsøkte å lage en sammenhengende livshistorie om seg selv. I dette kapitlet har datamaterialet blitt analysert med søkelys på hvordan barnevernet kom inn i bildet, og på hvordan de unge husker tilbake og vurderer barnevernets innsats.

Brukerundersøkelser om barns og unges erfaringer med barneverntjenesten gir andre typer data. Slike undersøkelser er gjerne rettet mot her-og-nå-situasjonen ogharsøkelyspårelasjonentilsaksbehandlerogopplevelsen av medvirkning i egen sak. En norsk kvalitetsundersøkelse blant barn som har vært i kontakt med barneverntjenesten (Oxford Research, 2017) viser at det er ganske stor variasjon i barns og unges erfaringer, for eksempel når det gjelder det å bli hørt, og om tiltak de fikk, virket. Denne undersøkelsen viser at mange barn og unge hadde gode erfaringer med sin saksbehandler og med det barnevernet gjorde. Undersøkelsen viser at de yngste barna er mer fornøyd enn de eldste. De som har store og sammensatte utfordringer i sin omsorgsituasjon, er mindre fornøyd enn barn og unge med mindre utfordringer. De fleste vi har snakket med hadde sammensatte og store utfordringer.

Dette kapitlet har et annet fokus enn slike brukerundersøkelser. Det søker å forstå disse ungdommenes synspunkter og erfaringer med barneverntjenesten i en bredere samfunnsmessig og sosiologisk kontekst. Et særlig søkelys rettes mot hvordan ungdommenes verdisyn knyttet til 
familie og tilhørighet kan være til hinder for at de søker og mottar hjelp fra barneverntjenesten. Nyere forståelser og begreper innen familie- og barndomssosiologi kan bidra til å få frem kulturelle verdier som er i spill når ungdommene skal håndtere sine foreldres vansker og problemer. Det er mange og sammensatte betingelser som virker inn på deres opplevelser og erfaringer. Disse kan ha større betydning enn det saksbehandlere i barneverntjenesten gjør i de konkrete møtene med de enkelte ungdommene. For eksempel vil familiens kulturelle verdi som sosialt og emosjonelt felleskap ha stor betydning for opplevelsen.

I den empiriske delen av kapitlet viser jeg først frem hva ungdommene sa om sine erfaringer med barneverntjenesten, og deretter hvordan dette kan forstås i lys av hvordan barn får en gryende forståelse av foreldrenes problemer. Videre beskrives den lange prosessen før de deler sin bekymring og fortvilelse med noen som kan vise dem vei inn i hjelpeapparatet.

\section{Familiens symbolske betydning i barns oppvekst}

Idealbildet av familien er at den skal bidra til å skape stabilitet, trygghet og kjærlighet for barn som ellers lever en omskiftelig tilværelse på ulike arenaer. Noen forskere hevder at den senmoderne familien kan beskrives som et intimitetsreservat med en tendens til å overbelaste familiene med emosjonelle og sosiale krav (Dencik, Schultz Jørgensen \& Sommer, 2008). De fleste foreldre har klare forestillinger om hva barn trenger, og disse bildene av god barneomsorg blir forsterket av populærvitenskapens formidling av godt foreldreskap. Senmoderne familieliv med små barn er barnesentrert eller nærmest barnedefinert (Dencik et al., 2008). Barnas behov står i sentrum for foreldrenes streben etter å få et godt liv, og familielivet reguleres av barnas behov. Disse og andre forskere hevder at det for eksempel er en moralsk forpliktelse i familierommet til alltid å sette barns behov i sentrum og til å ha disse som førsteprioritet når valg og prioriteringer skal gjøres (Brannen, Heptinstall \& Bhopal, 2000; Duncan \& Edwards 1999; Gillies, 2005; Hays, 1996). Det senmoderne foreldreskapet er et prosjekt som foreldrene, og da i særlig grad mødre, har et ansvar for å utforme på en måte som er til beste for barnet. Dersom man av 
forskjellige grunner ikke greier å forvalte dette ansvaret på en forsvarlig måte, kan det føre til at barna utsettes for «fare». Normalitetsbildene av velfungerende familier har gjennom faglitteratur, profesjonsutøvere i velferdssektoren, media, blogger og så videre, fått en enorm diskursiv makt som gjør det svært vanskelig å vise frem foreldrepraksiser som bryter med denne symbolske ordenen av selvfølgeligheter for god barneomsorg (Bech-Jørgensen, 1999) - eller det som Bruner (2002) kaller «det kanoniske kulturelle narrativet». Det kanoniske er det som er så selvfølgelig og vanlig at vi egentlig ikke tenker over det. Selv når foreldre strever med alvorlige psykiske helseplager, prøver mange å leve opp til idealet om det perfekte foreldreskap (Halsa, 2008, 2018), og dette gjelder i særlig grad mødre. I intervjuene jeg har gjort med mødre med psykiske helseplager (Halsa 2008, 2018), snakket de mye om hva de strevde med eller ikke fikk til i barneomsorgen. I nesten alle mødrenes fortellinger om sin tilkortkommenhet var det tydelig at de forholdt seg til normer som i litteraturen har blitt benevnt som «barneoppdragelse som intensiv kultivering» (Lareau, 2011). Dette kom for eksempel frem ved at de, til tross for egne plager og økonomiske bekymringer, fortalte om sine mangler slik: «Jeg har ikke kunne glede meg sammen med dem», «jeg har ikke orket å lese for dem» eller «jeg har ikke orket å leke med dem» (Halsa, 2008). Det kan se ut til at disse mødrenes idealer for godt foreldreskap langt overgår det som i barnevernfaglig kontekst benevnes som «godt nok foreldreskap».

Sosiologen Carol Smart (2007) har skrevet en bok der hun forsøker å begrepsfeste hva et familieliv kan være og bety i vår tid. I starten av boken drøfter hun hvorfor boken har fått tittelen Personal life, og hun begrunner dette med at familietilknytning preger folks liv og selvforståelse hele livet, og på mange flere områder enn det som vi gjerne forbinder med familiepraksiser eller familieliv. Hun har utforsket og skrevet om hvor viktig den symbolske betydningen av familiehistorier er for individers identitetsarbeid og forståelse av seg selv, og hun viser frem betydningen av emosjonelle relasjonelle praksiser. Hennes bidrag har vært en motstemme til de som hevder at familiens betydning er svekket, og til det som i sosiologien ofte blir beskrevet som individualisering og valgfrihet (Beck, 1997; Giddens, 1991). Familierelasjoner er bestandige, og selv om ekteskap løses opp, er de biologiske og sosiale båndene mellom barn 
og foreldre grunnleggende og vedvarende. Dette er i tråd med familieforskere som for eksempel Morgan (2019), Gillies (2005) og Lareau (2011), som alle understreker at selv om familiestrukturer endrer seg, er det stor grad av kontinuitet i familiens relasjonelle betydning. Det pekes også her på den dominerende makten bildet av den normale familien har, og på hvor viktig det er for folks identitet at de kan fortelle en respektabel familiehistorie fra sitt liv. Samtidig mener Smart (2007) at det har vært en overdreven tendens i sosiologisk litteratur til å rette oppmerksomheten mot tilhørighet, kjærlighet og omsorg når familielivet analyseres, og ikke på de negative sidene som tilhørighet og sterke relasjonelle bånd også kan ha. Hun bruker begrepet «the haunting power of blood relationship» for å illustrere at blodsbåndets makt kan oppleves som negativt og være vanskelig å fri seg fra, selv om man ønsker det. Det er forbundet med skam å bryte nære familiære bånd, sier hun. Et nærliggende eksempel kan være at dersom barn bryter kontakten med en eller begge av sine foreldre, vil alle forstå at i denne familien har noe ekstraordinært og uheldig skjedd, fordi det er så uvanlig at barn og foreldre ikke har livslang kontakt.

Wilson, Cunningham-Burley, Bancroft og Backett-Milburn (2012) har gjort en undersøkelse blant 38 unge (16-25 år) som har vokst opp i familier hvor en eller begge foreldrene har hatt rusproblemer. De retter det analytiske blikket mot disse ungdommenes relasjoner til foreldre og søsken. Undersøkelsen viser at selv om mange av ungdommene følte seg sveket av sine foreldre, var blitt kastet ut av hjemmet eller hadde liten kontakt med sine foreldre med rusproblemer, forsvarte de foreldrene og søkte etter tegn eller hendelser som viste at foreldrene likevel var glad i dem. De unge har en tendens til å idealisere familiebånd som det er lite styrke og hold i. Forskerne mener at denne idealiseringen kan skyldes at det ikke finnes tilgjengelige kulturelle narrativer de unge eller unge voksene kan anvende for å fortelle sin oppveksthistorie når de har hatt det så vanskelig. Videre peker de på at det er problematisk for de unge å legitimere at de bryter familiebåndene til en sårbar mor eller far, som ofte kan være svært avhengig av sine barns hjelp eller tilsyn. De så også hvordan noen lagde seg alternative familienarrativer ved å etablere familielignende relasjoner med steforeldre, familievenner eller profesjonelle. 
Denne teoretiseringen og forskingen peker på viktigheten av å forstå de idealiserte verdiene som familie og familiebånd representerer i vår kultur, og familiens betydning for «embeddedness» (Smart, 2007) eller tilhørighet. Barn og ungdom som opplever foreldrepraksiser som bryter med normative standarder og forstyrrer og ødelegger emosjonelle bånd, har vanskeligheter med å forstå situasjonen sin. De har problemer med å oppsøke hjelp, og de glatter over disse normative bruddene så godt de kan. Dette er tematikken som belyses i den empiriske delen av kapitlet, men først redegjøres det kort for data og metode.

\section{Metode og datagrunnlag}

Intervjuene som danner grunnlaget for dette kapitlet, ble samlet inn til et stort forskningsprosjekt om barns erfaringer med å vokse opp med psykisk syke og rusavhengige foreldre. Prosjektet var finansiert av Norges forskningsråd og var et samarbeid mellom flere forskere og stipendiater på Høgskolen i Lillehammer. Vi kalte prosjektet Mosaikkprosjektet. Ett av delprosjektene rettet spesiell oppmerksomhet mot barns og foreldres erfaringer, og i forbindelse med dette prosjektet intervjuet jeg, kollega Kerstin Söderström og tre masterstudenter til sammen 32 barn, unge og unge voksne om deres livshistorier.

De fleste deltakerne ble rekruttert gjennom ulike brukerorganisasjoner og via helsepersonell som hadde foreldrene eller ungdommene i behandling. Det var også noen som meldte seg selv etter at de hadde hørt oss snakke om tematikken. Den yngste som deltok, var 14 år, mens de fleste var i slutten av tenårene eller begynnelsen av tjueårene. Den eldste deltakeren var 32 år. Det er fire unge menn og 28 unge kvinner som har blitt intervjuet. Dataene ble samlet inn i tidsrommet 2014-2015.

For å gjennomføre disse dybdeintervjuene hadde vi utarbeidet en intervjuguide med åpne spørsmål. Vi la vekt på å få frem livshistoriene til informantene - om hvordan oppveksten og hjemmesituasjonen hadde vært, om skolehverdagen og om livet som ungdom. Vi var særlig opptatt av mestringsstrategier og av hvor de hadde søkt sosial støtte. Intervjuene ble tatt opp på bånd og transkribert. 
For å svare på problemstillingen er datamaterialet gjennomgått på nytt og analysert med henblikk på å få frem ungdommenes erfaringer med barneverntjenesten. Først fant jeg uttalelser som handlet om erfaringer med barnevernet. Deretter leste jeg gjennom intervjuene på nytt for å forstå disse erfaringene i lys av ungdommenes samlede narrativ. Jeg oppdaget da at alder hadde stor betydning for informantenes handlingsrom. Analysen fikk derfor en narrativ tilnærming, hvor tidsdimensjonen bandt hendelser sammen (Jansen, 2013), og hvor målet var å gå dypere inn i den enkelte historien og forsøke å forstå hvordan ulike hendelser og handlinger er bundet sammen. Sentrale elementer i det enkelte narrativet er historiens plott, sentrale aktører og viktige vendepunkter (Bruner, 1990). Plottet jeg var på jakt etter i denne analysen, var ungdommens kontakt og erfaringer med barneverntjenesten. Disse erfaringene forstås i lys av ungdommenes fortellinger om sin forankring i kjernefamilien og sin avhengighet av foreldrene, men også ut fra at alder har betydning for hva de forstår av måten egne vansker henger sammen med foreldrenes problemer på. De har det vondt, de forstår gradvis at det er foreldrenes problemer som påfører dem belastningene, men forankringen i kjernefamilien og avhengigheten av foreldrene gjør det nesten umulig for dem å hjelp hos andre. Kategoriene i analysen har derfor tidsdimensjon som organiserende prinsipp.

\section{Ungdommens erfaringer med barneverntjenesten}

Alle ungdommene som deltok i denne undersøkelsen, hadde felles erfaringer med å oppleve belastninger knyttet til mors eller fars rusproblemer eller psykiske lidelser. De hadde en følelse av at disse erfaringene ga dem en annerledes oppvekst enn andre barn. De forteller om mange vonde og svingende følelser, redsel, uforutsigbarhet og stort ansvar for småsøsken. Gjennomgående i alle historiene er at de har følt seg ensomme og alene med sine opplevelser og sitt strev. De har ikke kunnet snakke med noen, enten fordi de selv ikke har villet det, eller fordi ingen inviterte dem til å snakke om det. Alle forteller at det var først da de ble tenåringer, at det var mulig for dem selv å oppsøke eller 
ta imot hjelp fra andre enn nære slektninger. Men heller ikke da visste de hvem de skulle gå til, eller hvor de skulle oppsøke hjelp.

Mange forteller at familien har vært i kontakt med barnevernet i kortere eller lengre tid i oppveksten. De aller fleste ungdommene beskriver kontakten i negative termer. Felles for mange var opplevelsen av at barnevernet kom for sent inn. Ei jente med skilte foreldre og en alvorlig psykisk syk mamma forteller om dette slik:

Pappa tok kontakt med barnevernet fordi han var bekymret for mamma sin helsetilstand og at vi bodde hos henne. Men de kom inn for seint til at det kunne være noen hjelp. Hvis de skulle gjort noen forskjell, skulle det skjedd mye før. Jeg skulle jo snart flytte når de kom, jeg gikk siste året på videregående. (Jente, 19 år)

Mange husker at barnevernet kom på besøk i familien, men de er sterkt kritiske til at dette var planlagte tilsyn, for da ble huset satt i stand, og alle spor ble fjernet. En ung mann forteller:

De gangene barnevernet var koblet inn hos oss når jeg var liten, ga de alltid beskjed, og da var mamma i «forklemodus», som jeg pleide å si. Da hadde hun vasket og bakt boller og - ja, det ble aldri gjennomskuet. (Gutt, 26 år)

Det er også mange historier om at barnevernet var inne i familien en periode, men så skjedde det en bedring - ved at far kom på banen, at mor tok imot behandling, eller at en rusfri stemor eller stefar flyttet inn i hjemmet. Ifølge flere av ungdommene kunne slike endringer føre til at barneverntjenesten henla saker eller ikke undersøkte skikkelig hvordan forholdene var i hjemmet. Veldig mange beskrev hvordan de selv var med på å skjule foreldrenes rusbruk, og at de selv ikke fortalte om hvor vanskelig de hadde det. Ei jente (23 år) utrykte seg slik: «Barnevernsbarn er noen av de mest troverdige løgnere du kan komme over.» I hennes familie hadde barnevernet vært involvert siden hun gikk i barnehagen, med tiltak som urinprøve av mor og anmeldte og uanmeldte besøk. Da jenta var ti år, ble hun flyttet i fosterhjem på grunn av mors rusbruk. Hun flyttet tilbake til mor etter to år fordi det oppsto problemer i fosterfamilien. Hun forteller: 
Jeg var noen ganger på barneverntjenesten da [etter å ha flyttet hjem], og de spurte hvordan det gikk, og jeg sa «bra». Og de spurte «drikker hun ikke lenger?», og jeg sa «nei». Og de sa «så bra, da avslutter vi saken, da». Det var alt. De var ikke hjemme og sjekket. Og her tenker jeg at det er noe galt. Dette hadde pågått i ti år, og så avslutter de slik. Barn er jo opptatt av å holde ting skjult og si at alt er bra.

I ungdommenes fortellinger har barnevernet en perifer rolle. Noen husker konkrete episoder, andre har skjønt i ettertid at «siden jeg hadde et besøkshjem, må jo barnevernet ha vært 'inne'». Andre igjen forsto først at barneverntjenesten hadde hatt en rolle i familien når de begynte å undersøke «egen sak» som voksne. Nesten ingen husker navn på saksbehandlere de har møtt, og de blir uklare og vage når de skal fortelle om hvordan barneverntjenesten var involvert. I sine historier knytter de egne erfaringer med barneverntjenesten sammen med sin egen og foreldrenes måte å håndtere belastningene på. Mors eller fars problemer var ikke noe som ble snakket om i familiene. De fleste ungdommene måtte selv pusle sammen brikker for å forstå at noe var galt, og når de forsto hva som var galt, var det viktig å hjelpe foreldrene med å holde denne innsikten innenfor hjemmets fire vegger.

\section{Gryende forståelse - å pusle sammen brikkene}

Små barn er prisgitt sine omsorgspersoner. De forstår verden på bakgrunn av praksiser i de familienære situasjonene, og den verdenen de blir kjent med der er de rammene som fremstår som normale for dem (Bruner, 1990). Dette gjelder også for dem som i ettertid forteller om en kaotisk oppvekst knyttet til vold og omfattende rusbruk hos foreldre. Når de ser tilbake i dag, er det mange som husker episoder fra de er ganske små, og noen sier at minnene er veldig konkrete og knyttet til spesielle episoder. De begrunner dette med at det er så mange vonde følelser knyttet de tidlige barndomsopplevelsene. Likevel forsto de ikke da at noe var galt. Sitatene nedenfor viser hvordan to unge menn reflekterer over sin egen normalitetsforståelse etter at de har blitt unge voksne. 
Jeg husker at det var trist, og at det var mye redsel - men det sluttet etter en stund. For det var bare sånn det var - det var normalt - det skjedde jo hele tiden. Jeg har lest om omsorgssvikt i bøker, men det kjentes ikke slik - det var voldsomt, men ikke ekstremt. Men jeg hadde jo ikke noe å sammenligne med heller, for jeg har aldri opplevd noen annet. (Gutt 26 år)

Og jeg kan jo si, mildt sagt, at på det verste var det et helvete hjemme hos oss. Men det var ikke et helvete den gangen. Det var livet. (Gutt 23 år)

Mange forteller at de først forsto at noe var galt hjemme da de fikk venner som de kunne være med hjem, og da de begynte å sammenligne med hvordan andre hadde det. Ei jente som hadde en pappa med alvorlig psykisk lidelse, forteller at hun riktignok hadde blitt fortalt at pappaen var syk da hun var ganske liten, og hun sier videre:

Da forsto jeg ikke så mye annet enn at vi plutselig måtte reise fordi pappa var sint. Da så jeg på oss som en normal familie. Men plutselig forsto jeg at jeg aldri hadde levd i en normal familie. Det var på ungdomsskolen det gikk opp for meg.

I vårt materiale kan det se ut som at ungdom med foreldre som ruser seg med alkohol, forstår familieproblemene tidligere enn andre. Til forskjell fra piller eller illegale rusmidler er alkohol er et kulturelt akseptert rusmiddel som kan inntas med barn til stede, med synlige flasker på bordet. Barna kan se at foreldrene forandrer seg, og det kan knyttes til en konkret hendelse. En av informantene fortalte om dette:

Jeg var veldig liten da jeg forsto at mamma og pappa drakk. Det er en helt spesiell sans man utvikler. Jeg kunne høre på telefonen om de hadde drukket en øl. Og jeg kunne høre på skritt når jeg hadde lagt meg - om hvor fulle de var. Og på måten de åpnet og lukket dører på. (Voksen datter til to rusavhengige foreldre)

Mange opplevde det som en lettelse å forstå. Innsikten gjorde det mulig å gi mening til absurde hendelser og svik. Typisk for mange barn i slike livssituasjoner er at de tror det er deres feil at foreldrene er lei seg, sinte eller oppfører seg rart (Delås, 2015; Halsa, 2008; Velleman \& Templeton, 2016). Når de skjønner at det er sykdom eller rusavhengighet, kan det frata dem skyldfølelse. Samtidig er det mange som opplever en stor sorg 
når de erkjenner problemet. Dette er i tråd med funnene i undersøkelsen til Wilson og kollegaer (2012) om ungdom som vokser opp med rusproblemer hos foreldrene. Noen ble også veldig redde. Spesielt gjaldt det for dem som hadde foreldre som brukte illegale rusmidler. Frykten for at foreldrene kunne komme i fengsel, for at de kunne ta overdose, og for at noen skulle oppdage det, var spesiell for disse barna.

\section{Å forstå, men ikke kunne gjøre noe med det}

Når ungdommene forsto hva som var feil, ble det viktig for dem å holde det hemmelig, og at andre ikke skulle få vite og se hva som skjedde i familien. De fleste går på ungdomskolen når erkjennelsen kommer, og de forteller om angst, smerte, sinne, fortvilelse og taushet. De forteller om mobbehistorier og ensomhet. Flere har også detaljrike historier om mestringsstrategier, som å dukke inn i litteraturens univers eller høre på musikk med gode tekster som åpner opp for gjenkjennelse og viser at noen har forstått - eller å lukke seg inne på rommet med hodetelefoner og film og stenge verden ute. Alle ungdommene har historier om hva de gjorde for å dempe vanskene. For noen var dette aktiviteter og interesser som vi vanligvis vurderer som positive, mens andre fant rusen, pillene eller barberbladet. Felles for de fleste er at de er helt alene og ikke har noen å snakke med om hjemmesituasjonen.

Noen ble instruert av foreldrene til ikke å si noe til andre, mens det for andre var en selvfølge at de ikke måtte fortelle, slik som for denne gutten:

Jeg har gjort alt for å unngå barnevernet. For jeg visste de ville ødelegge familien, at de ville splitte oss. Og mor hadde sagt til meg at jeg ikke måtte fortelle andre om det som skjedde hjemme. «Det må du ikke si til noen», sa hun ofte til meg. Til ingen. Og det ordet holdt jeg til den dagen [da han fortalte alt til en lærer]. (Gutt, 23 år)

Ei ung jente (17 år) som har vokst opp med en enslig mor med store alkoholproblemer og et tett familienettverk, forteller om hvor umulig det var for henne å si ifra til farmor om hvordan hun hadde det hjemme. Hun har hatt feriesamvær med far, som bor på en annen kant av landet. Hun er fortvilet over morens rusbruk, og hun sier at hun har vært redd, 
innesluttet og deprimert av alt ansvaret og av det ustabile livet hjemme. Hun sier:

Pappa trodde alt var i orden, siden jeg ikke fortalte noe. Farmor har jeg alltid hatt mye kontakt med, men jeg fortalte det ikke til henne heller. For jeg ville ikke at hun skulle få et negativt forhold til mamma. Både hun og tanta mi visste at mamma hadde hatt alkoholproblemer før, men jeg løy og sa at jeg hadde det bra. Jeg hadde noen ganger lyst til å fortelle, men følte jeg ville skade mamma med det ... Et barn greier ikke å si ifra når det er noe med foreldrene deres. De vil nekte og si «nei, vi har det kjempebra».

Det er mye som står på spill for mange av disse ungdommene, noe som gjør det umulig å fortelle til andre. De er redde for å splitte familien, som gutten ovenfor. De vil beskytte sine foreldre, som de bor hos, er glad i og avhengige av. Sitatet nedenfor illustrerer dette relasjonelle avhengighetsforholdet. Denne jenta, som ble satt i kontakt med barnevernet da hun var 13-14 år, sa:

Vi snakket med en der nede [i barneverntjenesten], og han spurte om jeg var interessert i å flytte til et fosterhjem. Så spurte han om jeg ville levere bekymringsmelding. Jeg sa nei, for jeg var ikke forberedt på det, og jeg ville det jo heller ikke. Jeg kunne ikke backstabbe mamma. Min tillit lå jo hos henne.

Og der endte saken så langt. Først to-tre år senere fikk denne jenta hjelp til å flytte ut fra det hun selv opplevde som en veldig ulykkelig familiesituasjon.

I profesjonelt arbeid og i forskning med barn og unge forklares ofte ungdommens taushet og hemmeligholdelse med lojalitet til foreldrene. Vi ser av sitatene ovenfor at det også handler om ungdommens sterke tilknytning og tilhørighet til egen familie - om blodsbåndenes betydning, som Smart (2007) skriver om. Hvilke historier det er mulig å fortelle om foreldrene sine, har også betydning for egen identitet og for hvordan de presenterer seg for andre. Ei jente (17) som hadde en pappa som periodevis var alvorlig psykotisk, sa at hun fortalte vennene sine at faren var psykisk syk, men likevel måtte noe holdes skjult av hensyn til pappa og henne selv. Hun sa: 
Ingen må få se pappa når han kjefter, og høre hva han sier, det har jeg aldri sagt til vennene mine, for jeg vil ikke at de skal få et slikt inntrykk av pappa. At han bruker slike ord. For har de sett det, så har de sett det for alltid.

Hvis noen så hvordan faren var når han var psykotisk, ville altså bilder av den normale pappaen forsvinne - og derved også det normalitetsbildet vennene hadde av familien og henne selv. Dette sitatet illustrerer hvordan ungdoms identitetsforhandlinger er nært knyttet til familien de kommer fra, og hvordan familiebildet utgjør en sentral del av ungdommens eget selvbilde.

\section{Å åpne opp og endelig fortelle}

Noen utviklet etter hvert så store egne problemer at de oppsøkte eller ble henvist til psykolog eller terapi. Noen måtte bli voksne og flytte hjemmefra før de kunne ta tak i sine historier. Som en sa: «Jeg bare venta til jeg kom i en alder hvor jeg kunne bestemme sjøl.» Og mange av disse fikk etter hvert hjelp i terapirommet eller fra selvhjelpsgrupper. Men det er også en del informanter som forteller at de på slutten av ungdomskolen eller i begynnelsen av videregående ble fanget opp av en årvåken lærer, en bekymret venninne eller kjæreste. Jenta som ovenfor fortalte om at hun ble fulgt til barnevernet da hun var 13-14 år, fortsetter sin historie slik:

To år etter tok min venninnene meg med for å snakke med en sosialarbeider som vi kjente fra skolen. Da måtte jeg tenke på meg selv, ellers vet jeg ikke hva som hadde skjedd. Han leverte bekymringsmelding til barnevernet. Jeg synes det var veldig skummelt at barnevernet ble kontaktet. Jeg var usikker og tvilte på meg sjøl, om dette var lurt, og om det var verdt det. Jeg lurte på om jeg hadde det ille nok til at det var greit å gjøre det.

Denne jenta var en av veldig få som ble hjulpet $\mathrm{i}$ kontakt med barnevernet da hun var 16 år. Sitatet viser den høye terskelen ungdommene hadde for å søke hjelp hos barnevernet. Mange gir utrykk for tanker om at det å ta kontakt med barnevernet betyr at de forråder sine foreldre, og at det er en egoistisk handling. For en del var det tilfeldigheter som gjorde at lærere på skolen oppdaget problemene hjemme. En gutt beskriver seg selv som 
en pliktoppfyllende elev. En dag hadde han ikke fått gjort lekser, og han ba om å få snakke med læreren for å fortelle at han ikke hadde fått gjort hjemmearbeidet sitt:

Jeg ba læreren om en samtale, og så begynte jeg å grine. Og da hørte han på meg. Jeg fortalte om situasjonen hjemme, og at jeg ikke orket mer. Han sa til meg at jeg kunne gå ned til barnevernet etter skolen. Så ringte han og gjorde en avtale. Jeg møtte en dame som var pent kledd. Og vi snakket, og hun spurte meg hva slags familie jeg kunne tenkte meg - om de skulle ha hund, om det skulle være flere barn. Jeg husker jeg kom hjem og måtte på do, og da spurte jeg meg selv om det var siste gang jeg skulle tisse på denne doen. Om jeg kom til å se brødene mine mer - og kanskje heller ikke mor, for jeg hadde ødelagt forholdet mellom oss. Og jeg visste ikke hva som var best for meg.

Svært mange av de som avslørte de vanskelige hjemmeforholdene som 16-17-åringer, brukte ord som «jeg orket ikke mer», «jeg hadde det så vondt», «jeg måtte tenke på meg sjøl», «jeg trengte desperat noen å snakke med». Likevel var det å gå selv til barneverntjenesten siste utvei og en avgjørelse som ungdommene mente kunne splitte familiene og ødelegge relasjonen til foreldrene. Å kontakte barnevernet var i mange av disse ungdommenes øyne det samme som å svikte foreldrene. Barneverntjenesten ble av de færreste sett på som en relevant hjelpeinstans.

\section{Diskusjon}

Selv om ungdommenes oppveksthistorier er forskjellige og har mange nyanser og stor variasjon i hvor tunge belastninger de har opplevd, er det likevel noen fellestrekk ved nesten alle historiene. For det første er det den ekstremt lange og kronglete veien frem mot å forstå og erkjenne for seg selv at det er noe galt med mamma eller pappa. For det andre er det å vite hvordan man skal opptre for å holde denne kunnskapen for seg selv. For det tredje er det å finne frem til adekvat hjelp når behovet blir akutt, og samtidig avveie dette mot hensynet til foreldrenes integritet. Ved å fortelle sin historie om egen uro og foreldrenes rus og psykiske vansker havner de utenfor vår kanoniske kulturelle fortelling om familier, foreldre og barndom. Dette er en gedigen verdikollisjon mellom hvordan 
det burde være, og hvordan det er. Barna og ungdommene blir overlatt til seg selv for å takle de mange misforholdene - misforholdet mellom hva de trenger og hva de får, mellom hva de andre tror og hvordan det er, mellom behovet for beskyttelse og trygghet og redselen for hva som skjer hvis de forteller, mellom hensynet til seg selv og hensynet til forelderen eller familien. Det tydelige budskapet i alle historiene er at «barn greier ikke å fortelle». De sier ikke dette fordi de ser på seg selv som offer eller passive aktører. Fortellingene viser snarere det motsatte - at tausheten eller «løgnene» er en aktiv strategi for å beskytte og ta vare på foreldrene og sin egen plass i verden. De viser, på en entydig måte, familiens sterke symbolske verdi (Smart, 2007).

Historiene til disse ungdommene bryter med diskursen eller ideen om den lykkelige barndommen (Hennum, 2002). Diskurser bestemmer mulighetsrom for hvem disse ungdommene kan være, og ved å holde skjult for omverdenen hva som skjer hjemme, kan ungdommen skape et bilde av seg selv som en vanlig ungdom. Ifølge Smart (2007) er forankringen i familie og slekt helt grunnleggende for menneskers selvforståelse og identitetsarbeid. Slekt og familie utgjør ifølge henne et spindelvev av relasjoner og emosjoner som unge mennesker er så innvevd $i$ at det blir umulig for dem å bryte ut. «Du forteller om deg selv når du forteller om din familie», sier hun, et sitat som tydelig illustrerer familiebåndets betydning for identitetsdanning (Smart, 2007, s. 86). For å forstå ungdommens problemer med å ta kontakt med barnevernet, og at noen «gjør alt for å unngå barnevernet», må vi forstå de idealiserte verdiene familietilhørighet representerer i vår kultur. Denne kunnskapen hjelper oss til å forstå de refleksjonene som gutten som fortalte at han hadde vært på barnevernet, gjorde etter det første besøket. Han tenkte at dette besøket kunne medføre at han måtte flytte, bytte hjem og do, og at han kunne miste kontakten med brødrene og mor.

Historien til denne gutten og en del av de andre ungdommene viser også at barneverntjenesten blir sett på som en instans som splitter barn og foreldrene. Dette er ikke en forestilling som finnes bare blant innvandrerfamilier, men også blant barn og unge som trenger den hjelpen barnevernet kan tilby. Ungdommenes fortellinger viser frem barnevernets legitimitetsproblemer. Tjenestens samfunnsmandat er både hjelp og 
kontroll. Det som kommer frem i intervjuene, er at forholdet til barnevernet er preget av stor ambivalens. Ungdommene er klar over at de har behov for hjelp, samtidig som kontakten med barnevernet har uønskede konsekvenser, som at de kan miste kontakt med familiemedlemmer eller ødelegge relasjonen til foreldre.

Et påfallende funn i denne undersøkelsen er at til tross for at mange av ungdommene beskriver oppvekster med vold, omsorgssvikt og å bli forlatt hjemme alene, har barnevernet en svært perifer plass i oppveksthistoriene. Dette er i tråd med Jansen (2019) sine funn. Hun har intervjuet tolv ungdommer som har bodd på barneverninstitusjoner. Ungdommene ble intervjuet tre ganger over en periode på 15 måneder. Jansen har analysert datamaterialet med utgangspunkt i hvilken betydning ungdommene tillegger barnevernet i sine historier om eget dagligliv. Hun sier at det var store variasjoner i hvor mye ungdommene snakket om barnevernet, men at det i mange av intervjuene var fraværet av referanser til barnevernet som overrasket mest. Jansen sier at det å være i kontakt med barnevernet assosieres med det å være problembarn. En grunn til at ungdommene tematiserte barnevernet negativt eller ikke i det hele tatt, kan være at de prøver å vri seg unna merkelappen «problembarn», og dette kan derved forstås som en form for identitetsarbeid. Når barn som bor under omsorgsregimer som barnevernet har ansvar for, snakker lite om barnevernet er det kanskje ikke så underlig at barnevernet er en tematikk som fikk liten plass i våre ungdommers fortellinger.

I innledningen til dette kapitlet pekte jeg på at barns rett til å bli hørt og til å delta i egen sak er en svært sentral verdi i barnevernets lovgrunnlag. Med bakgrunn i disse ungdommenes fortellinger om hvordan de benekter og lyver om egne foreldres problemer, stilles barneverntjenesten overfor store utfordringer, kanskje særlig knyttet til verdien av barns medvirkning og til hvordan de skal få ungdommene i tale om foreldrenes problemer - og om de konsekvensene dette har for barns og unges oppvekstsituasjon. Spørsmålet man kan stille, er hvordan barnevernet kan legge til rette for barns og unges medvirkning samtidig som disse ungdommene gis muligheten til å ivareta sin egen og foreldrenes integritet og retten til et familieliv. Her er det ingen enkle svar, men det krever tid og varsomhet å bygge opp en trygg relasjon som innebærer at barn 
kan fortelle om sine foreldres vansker, uten at de føler at de utleverer og baksnakker personer de føler seg sterkt knyttet til.

\section{Litteratur}

Backett-Milburn, K., Wilson, S., Bancroft, A. \& Cunningham-Burley, S. (2008). Challenging childhoods: Young people's accounts of 'getting by' in families with substance use problems. Childhood, 15, 461-479.

Bech-Jørgensen, B. (1999). Normalitetsbilder. Aalborg: Alfuff.

Beck, U. (1997). Risiko og frihet. Bergen: Fagbokforlaget.

Brannen, J., Heptinstall, E. \& Bhopal, K. (200o). Connecting children: Care and family life in later childhood. London: Routledge Falmer.

Bruner, J. (1990). Acts of meaning. Cambridge, MA: Harvard University Press.

Bruner, J. (2002). Making stories: Law, literature, life. Cambridge, MA: Harvard University Press.

Delås, G. M. (2015). Barn i familier med alkoholproblemer og skam - Barn i familier med alkoholproblemer er ofte bærere av skam. Hva kan være årsakene til skamfølelsen, hvordan oppleves den, og hvordan påvirker den deres hverdag? Tidsskrift for psykisk helsearbeid, 12(4), 298-306.

Dencik, L., Schultz Jørgensen, P. \& Sommer, D. (2008). Familie og børn i en opbrudstid. København: Hans Reitzels forlag.

Duncan, S. \& Edwards, R. (1999). Lone mothers, paid work and gendered moral rationalities. Basingstoke, England: Palgrave Macmillan.

Finch. J. (2007). Displaying families. Sociology, 41(1), 65-81.

Forandringsfabrikken. (2017). Barnevernet fra oss som kjenner det. 62 fortellinger fra 62 ungdommer. Hentet fra https://www.regjeringen.no/contentassets/ a40b74a5ffb743168e41fd1b325b9b6e/forandringsfabrikken.-nettsiden.pdf

Giddens, A. (1991). Modernity and self identity: Self and society in late modern age. Cambridge, England: Polity Press.

Gillies, V. (2005). Raising the 'meritocracy': Parenting and the individualization of social class. Sociology, 39(5), 835-853.

Halsa, A. (2008). «Mamma med nerver». En studie av moderskap og barneomsorg $i$ velferdsstaten, når mor har psykiske helseplager. Doktoravhandling, Institutt for statsvitenskap og sosiologi. Norges teknisk-naturvitenskapelige universitet, Trondheim.

Hays, S. (1996). The cultural contradictions of motherhood. New Haven, CT: Yale University Press.

Halsa, A. (2018). Trapped between madness and motherhood: Mothering alone. Social Work in Mental Health, 16(1), 46-61. https://doi.org/10.1080/15332985.2017.1317688 
Hennum, N. (2002). Kjorlighetens og autoritetens kulturelle koder: om å voere mor og far for norsk ungdom. (Doktoravhandling, rapport 19/o2). Norsk institutt for forskning om oppvekst, velferd og aldring, Oslo.

Jansen, A. (2013). Narrative kraftfelt. Psykologisk utvikling hos barn og unge i et narrativt perspektiv. Oslo: Universitetsforlaget.

Jansen, A. (2019). Barnevernets plass i fortellingene til unge i barnevernsinstitusjoner. I A. Jansen \& A. Andenæs (Red.), Hverdagsliv, barndom og oppvekst. Teoretiske posisjoner og metodiske grep. Oslo: Universitetsforlaget.

Kommisrud, K., Söderström, K., Halsaa, L. \& Halsa, A. (2019). «Jeg er ikke noe offer for mamma». Ungdoms søken etter mening og sammenheng i dobbeltrollen som pårørende og BUP-pasient. Fokus på familien, 47(2), 82-101.

Kufås, E., Faugli, A. \& Weimand, B. (2015). Barn og ungdom som har foreldre med rusmiddelproblemer - en kvalitativ levekårsstudie. Oslo: Helsedirektoratet.

Lareau, A. (2011). Unequal childhoods: Class, race, and family life (2. utg.). Berkeley, CA: University of California Press.

Moore, T, McArthur, M. \& Noble-Carr, D. (2011). Different but the same? Exploring the experiences of young people caring for a parent with an alcohol or other drug issue. Journal of Youth Studies, 14(2), 161-177. https://doi.org/10.1080/13676261.20 10.522561

Morgan, D. H. J. (2019). Family practices in time and space. Gender, Place and Culture, 27(5), 733-743. https://doi.org/10.1080/0966369X.2018.1541870

Oxford Research. (2017). Kvalitetsundersøkelse blant barn som har vært i kontakt med barneverntjenesten. Hentet fra https://oxfordresearch.no/wp-content/ uploads/2017/12/Undersøkelse_barnevern_bergen.pdf

Smart, C. (2007). Personal life: New directions in sociological thinking. Cambridge, England: Polity Press.

Sundfær, A. (2012). God dag, jeg er et barn: om barn som lever med rus eller psykisk sykdom i familien. Bergen: Fagbokforlaget.

Söderström, K. (2017). Barn i familiens vold. I Barn i Norge (årsrapport 2017). Oslo: Voksne for Barn.

Templeton, L. J., Novak, C. \& Wall, S. (2011). Young people's views on services to help them deal with parental substance misuse. Drugs: Education, Prevention and Policy, 18(3), 172-178. https://doi.org/10.3109/o9687637.2010.489081

Velleman, R. \& Templeton, L. J. (2016). Impact of parents' substance misuse on children: An update. BJPsych Advances, 22(2), 108-117. https://doi.org/10.1192/apt. bp.114.014449

Werner, A. \& Malterud, K. (2016). Children of parents with alcohol problems performing normality: A qualitative interview study about unmet needs for professional support. International Journal of Qualitative Studies on Health and Well-being, 11(1). https://doi.org/10.3402/qhw.v11.30673 
Wilson, S., Cunningham-Burley, S., Bancroft, A. \& Backett-Milburn, K. (2012). The consequences of love: Young people and family practices in difficult circumstances. Sociological Review, 6o(1), 110-128. https://doi.org/10.1111/j.1467954X.2011.02049.X

Wangensteen, T., Bramness, J. G. \& Halsa, A (2018) Growing up with parental substance use disorder: The struggle with complex emotions, regulation of contact, and lack of professional support. Child \& Family Social Work, 1-8, https://doi.org/10.1111/cfs.12603 


\title{
«SIM spedbarnevern og foreldrestøtte»: Simulering av tverrfaglig samarbeid i verdiladde og sårbare situasjoner
}

\author{
Kerstin Söderström
}

Førsteamanuensis, Høgskolen i Innlandet

\section{Anders Sandvig jr.}

Førstelektor, Høgskolen i Innlandet

\begin{abstract}
This chapter describes and evaluates the model of medical simulation as a learning strategy to handle complex, value-laden situations and decisions in child protection. Participants were bachelor students in social work and practitioners from different health and social services. The topic of scenario training was multidisciplinary teamwork in separating newborns and parents at the maternity ward with aims to: 1) stimulate ethical and professional reflexion and improve skills in interdisciplinary teamwork, and 2) combine education and practice to improve both. The theoretical framework is inspired by Lave's theory of situated learning and Jeffries' simulation theory. A qualitative, action-oriented research strategy was used. The simulation served simultaneously as education, as-if real practice, and research. Reflection notes, participant observations, debriefing discussions between the participants, and an electronic feedback questionnaire provided the data. 174 students and 110 professionals participated in a total of 30 small group simulations. Feedback showed that participants believed that simulation would enhance their self-confidence and competence in real-life situations. Students experienced the scenario training as making practical sense of theory and teaching. Many saw this as a preparation step to their future profession. Results indicate that scenario training strengthened mutual respect and the ability to consider multiple perspectives. It provided a safe, structured, collaborative situation with potential to lower tensions and value conflicts between professions.
\end{abstract}

Sitering av denne artikkelen: Söderström, K. \& Sandvig, A. (2020). «SIM spedbarnevern og foreldrestøtte»: Simulering av tverrfaglig samarbeid i verdiladde og sårbare situasjoner. I H. Nordby \& A. Halsa (Red.), Verdier i barnevern (Kap. 9, s. 173-197). Oslo: Cappelen Damm Akademisk. https://doi. org/10.23865/noasp.103.ch9

Lisens: CC BY-ND 4.0 
Keywords: medical simulation, child protection, care orders, newborns, values, multidisciplinary teamwork

\section{Barnevern, et ubestridt gode og et nødvendig onde}

Vern om familietilhørighet og retten til privatlivets fred - og å sikre barn tilstrekkelig beskyttelse når omsorgssituasjonen vurderes som skadelig er en krevende balanseøvelse. Vanskelige avveiinger og mulige verdikonflikter ligger innebygd i barnevernets sentrale førende prinsipper: barnets beste, det biologiske prinsipp og prinsippet om minste mulige inngripen (Netland, kapittel 3). Barnevern er ikke barnevernets eneansvar, men et samfunnsansvar. Det er alle voksnes moralske ansvar, og helse- og omsorgstjenestenes lovpålagte ansvar, å melde bekymring og samarbeide for gode løsninger til barnets beste.

Men i praksis er tverrfaglig samarbeid i barnevernssaker ofte vanskelig og spenningsfylt. Barnevernets samarbeidsparter trer inn i samarbeidet med sine respektive posisjoner, fagkunnskap og juridiske mandat. Dessuten har hver yrkesgruppe og tjeneste utviklet spesifikke kjerneverdier som farger deres faglige forståelse og yrkesetikk (Nordby, kapittel $4 \mathrm{i}$ denne boken). At det oppstår spenninger og verdikollisjoner i tverrfaglig samarbeid i barnevernssaker, er å forvente. Dette kapitlet fokuserer mer på utvikling av samarbeidskompetanse og forståelse for hvordan bakenforliggende verdier og holdninger spiller seg ut på samarbeidsarenaer, enn på selve innholdet i verdikonfliktene. Det handler om tverrfaglig simulering som metode for å forstå og håndtere tverrfaglig samarbeid $\mathrm{i}$ en komplisert, sjelden og verdiladd barnevernsoppgave, nemlig spedbarnevern og separasjon av mor og barn like etter fødsel.

De sentrale verdikonfliktene er allerede beskrevet i kapittel 7 (Söderström) som tre ulike perspektiver og posisjoner: et medisinsk, et psykososialt og et barnevernfaglig. Den medisinske posisjonens oppgaveforståelse er først og fremst å behandle og lindre lidelse hos den som defineres som primærpasient. Eller, som her, å støtte en gravid gjennom svangerskapet og gi omsorg og pleie til mor og barn etter fødselen. Barneverntjenesten vil med dette utgangspunktet kunne oppfattes som brutal, mens fra barnevernets 
posisjon kan behandlingsprofesjonene oppfattes som unnvikende og uansvarlige med tanke på barnets ve og vel. En akutt separasjon kan komme i konflikt med helsepersonells verdsetting av relasjonen til pasienten eller barselpersonalets forståelse av egen rolle og fagetikk. Dette er satt på spissen, for barnets beste er et førende prinsipp for alle involverte parter. Likevel vil ulike fagfolk kunne komme frem til ulik vektlegging av hva som er viktigst og riktigst å gjøre. Motstridende verdier former handlingspreferansene, og det oppstår en verdikonflikt (Nordby, 2017).

Separasjon av mor og nyfødt barn er en sterk inngripen i en særdeles inntrykksøm, meningsmettet og privat familiesituasjon. Barnet er fullstendig avhengig av omsorgspersonen(e). Mange vil oppfatte en atskillelse på fødestuen som naturstridig og på tvers av grunnleggende antakelser og verdier i samfunnet. Den europeiske menneskerettighetsdomstol (EMD) uttrykker at en slik separasjon krever en eksepsjonell sterk begrunnelse (Freel, 2010). Ferske EMD-dommer (Søvig, 2019) som anerkjenner behovet for inngrepet, er likevel kritiske til det som skjer etter separasjonen. Men beskyttelse av barn i fare er en like sterk «magefølelse» og samfunnsverdi, og manglende beskyttelse vekker i like stor grad moralsk fordømmelse.

Akutt omsorgsovertakelse ved fødsel er således en fortettet, verdiladd situasjon som stiller store krav til de profesjonelle aktørene. Vi vet at det lett oppstår konflikter, men vi kan mindre om hvordan spenninger og verdikonflikter kan forebygges og håndteres. Jo mer inngripende tiltak, desto mer belastende er det å forvalte en skjønnsbasert beslutning. Dette «skjønnets byrde» (Grimen, 2008) har gitt opphav til kvalitetssikringssystemer og prosedyrer som beslutningsstøtte. Tanken er at beslutningene blir mer systematiske og bedre - og mindre avhengig av personlig og faglig skjønn. Fagpersonen får mindre ansvar for sin skjønnsutøvelse så lenge prosedyrene er fulgt.

Læringsprosjektet vi presenterer her, har som mål å utvikle gode tverrfaglige praksiser ved omsorgsovertakelse ved fødsel ved å lære, øve og reflektere sammen. Antakelsen var at opplegget kan overføres til andre av barnevernets oppgaver, for eksempel uanmeldte hjemmebesøk, andre akutte omsorgsovertakelser, formidling av vanskelige beskjeder, håndtering av trusler og konflikter og samtaler med barn i ulike aldre. Prosjektet 
«SIM barnevern og foreldrestøtte» prøver ut simulering som læringsmetode for utvikling av faglig refleksjon og god praksis, hvor omsorgsovertakelse ved fødsel brukes som case.

Kapitlet henger sammen med kapittel 7 (Söderström), som beskriver hvordan et tverrfaglig arbeid rundt den gravide «Maria» utviklet seg gjennom spenninger og konflikter, men til slutt landet i en felles forståelse. Hovedlinjene i spenningene oppsto mellom helse, behandling og barnevern og - ikke uventet - mellom de som primært hadde ansvar for mor, og de som hadde barnets ve og vel som sitt mandat. I dette eksemplet løste konfliktene seg, kanskje hjulpet av den nøytrale veilederen. Den beskrevne samarbeidsprosessen var dessuten strukturert med tid og rom for felles refleksjon og likeverdig deling av synspunkter i en kollegial omgangs- og organisasjonsform.

Vår antakelse er at en likeverdig, kollegial arbeidsmåte er under særlig press i kompliserte barnevernbeslutninger og -tiltak. Hjelpeapparatet har sine hierarkier. Tverrfaglig samarbeid er nødvendig, men krevende. Spenninger mellom barnevernet og samarbeidende helse- og omsorgstjenester er vanlig (Munro, 2011). Vi antar videre at jo mer verdiladd saksinnhold, desto sterkere potensial for samarbeidskonflikt. Troen på at konstruktivt, likeverdig tverrfaglig samarbeid kan styrkes gjennom læring og erfaring, er én sentral begrunnelse for prosjektet «SIM spedbarnevern og foreldrestøtte». SIM er her en forkortelse for simulering, eller medisinsk simulering, som er en strukturert ferdighets- og samhandlingstrening $\mathrm{i}$ et virkelighetsnært scenario (Gaba, 2004). Prosjektet er i tillegg motivert ut fra følgende spørsmål:

1) Hvordan kan utdanningene forberede studenter på kompleksiteten i tverrfaglig samarbeid og gi dem forståelse for fag- og verdirelaterte spenninger?

2) Hvordan kan studenter og det tverrfaglige praksisfeltet få erfaring med noe så vanskelig og sjeldent forekommende som omsorgsovertakelse ved fødsel?

3) Kan en felles SIM «treningsarena» bidra til ny kunnskap om samarbeid i krevende barnevernarbeid, stimulere refleksjon og omdannes til bedre praksis? 
«SIM spedbarnevern og foreldrestøtte» er altså et undervisningsopplegg for studenter, et trenings- og kompetansehevende tiltak for fagfolk og et forsknings- og fagutviklingsprosjekt. Koblingen av studenter og fagpersoner ble gjort for å knytte utdanning og praksis nærmere sammen, og for å gjøre opplegget mer realistisk for begge parter. Ved siden av å trene på det som er sjeldent og ekstra vanskelig, var læringsmålene forankret i verdien av god kommunikasjon, godt samarbeid og respekt samt ivaretakelse og rettsvern for mennesker som utsettes for inngrep mot sin vilje. Undervisningsprosjektet er, i likhet med prosjektet Nattergalen beskrevet av Roland, (kapittel 10), en praktisk, erfaringsbasert læring som gir studenter mulighet til å identifisere, forstå og håndtere verdikonflikter. I Nattergal-prosjektet handler det om spenninger og verdikonflikter mellom kulturer. I «SIM spedbarnevern og foreldrestøtte» handler det om vanskelige oppgaver og potensielle verdikonflikter mellom ulike profesjoner.

I det følgende beskrives koblingen til barnevernets samfunnsmandat og kompetansekrav. Så begrunnes behovet for situert, praksisnær læring og ønsket om å studere en lite synlig del av barnevernets oppgaver. Deretter forklarer vi de læringsteoretiske antakelsene om simulering, hvordan «SIM spedbarnevern og foreldrestøtte» ble gjennomført, og vår forskningsstrategi. Til slutt presenteres og diskuteres deltakernes erfaringer.

\section{Forberedelse til et krevende samfunnsmandat}

Barnevernet er gitt et krevende samfunnsmandat med tilhørende stor makt. Oppgavene stiller store krav til ansattes kunnskap og handlingskompetanse på mange ulike områder (Bufdir, 2018). Nasjonale retningslinjer for helse- og sosialfagutdanningene (Kunnskapsdepartementet, 2017) beskriver at etter endt utdanning skal fagpersonen ha samarbeidskompetanse både tverrfaglig, tverrprofesjonelt og tverrsektorielt for å kunne møte kravene i yrket. Utdanningene bør tilrettelegges slik at studentene får trening i kritisk og etisk refleksjon samt praktiske ferdigheter. Ny forskrift om nasjonal retningslinje for barnevernspedagogutdanning (Kunnskapsdepartementet, 2019) beskriver sentrale kompetanseområder 
som barnevernfaglig kompetanse, oppvekst og familieliv, yrkesrolle, etikk og samarbeid til barnets beste. Studiet skal stimulere til kunnskapsbasert praksis, kritisk tenkning, blikk for forbedring og innovasjon.

Dagens studenter skal forberedes til å stå i yrkets emosjonelt krevende situasjoner uten å miste profesjonalitet, og uten selv å ta skade av det. Barne-, ungdoms- og familiedirektoratets utredning av kompetansebehovene i barnevernet (Bufdir, 2019) viste at kun 35 prosent av ansatte $\mathrm{i}$ barneverntjenesten mener at deres grunnutdanning i stor eller svært stor grad ga dem et godt grunnlag for å arbeide i tjenesten. Kompetanseutredningen hevder at:

[U]tdanningsinstitusjonene har færre muligheter til å undervise studentene i små grupper, gi dem tilstrekkelige kliniske ferdigheter og bli godt kjent med dem, slik at de kan vurdere skikkethet for å arbeide i barnevernet. I stedet må undervisningen foregå i større forelesninger, noe som innebærer at utdanningen blir mer teoretisk. Mange studenter får lite eller ingen praktisk trening i å arbeide i barnevernet i løpet av utdanningen. (Bufdir, 2019, s. 4)

Stortingsmeldingen «Utdanning for velferd - samspill i praksis» (Kunnskapsdepartementet, 2012) slår fast at det er behov for mer samarbeid og bedre sammenheng mellom utdanning og praksis.

Dette er én del av bakteppet for prosjektet «SIM spedbarnevern og foreldrestøtte». Den andre delen er å studere og trene på problemstillinger og praksis rundt omsorgsovertakelse ved fødsel.

\section{Hvorfor trene på omsorgsovertakelse ved fødsel?}

Separasjon av mor og barn like etter fødsel er, som nevnt, et av barnevernets mest inngripende tiltak i en særdeles følelsesladd og kompleks situasjon. Det skjer sjeldent, i underkant av en gang per uke på landsbasis (Dyrhaug, 2019). Dette kombinert med høy personalutskifting gjør at fagfolk og tjenester får begrensede muligheter til å opparbeide seg erfaring og drive kontinuerlig praksisforbedring. Faglig og juridisk skjønn i tiden rundt barnets fødsel er vanskelig, blant annet fordi det må baseres på antakelser om fremtidige hendelser og hvordan disse vil påvirke barnet på kort og lang sikt. Alle nivåer av verdier er i 
spill - samfunnsmessige, kulturelle, fagbaserte og personlige (Nordby \& Halsa, kapittel 1). Barneverntjenesten kan lett havne i konflikt og spenning mellom egne vurderinger av hva som er nødvendige inngrep, og hva andre opplever som maktmisbruk og overtramp overfor enkeltmennesker og familier. Mange av sakene som har vært behandlet i Den europeiske menneskerettighetsdomstolen (EMD), handler om barnevernets inngrep for å verne nyfødte og det som skjer i etterkant (Søvig, 2019). Domfellelsene forteller at EMD vektlegger verdien av familie og bånd til biologiske foreldre sterkere enn norsk barnevern- og rettspraksis (se kapittel 2 av Bennin).

Hendelsen er sjelden, inngripende, faglig og verdimessig komplisert, og den kan utfordre rettssikkerheten. Dette tilsier at tverrfaglige team og studenter bør lære om og øve på faglig forsvarlig og rettssikker praksis ved omsorgsovertakelse ved fødsel.

\section{Simulering - en form for situert læring}

Medisinsk simulering er øvelse på faglige ferdigheter i et arrangert, men realistisk scenario med konkrete læringsmål. Scenarioet trekker deltakeren inn i en opplevelse som fremkaller eller etterligner vesentlige aspekter ved det virkelige, og det mobiliserer handling og interaksjon (Gaba, 2004). Dette gir fagfolk en mulighet for å prøve og feile, uten at det går ut over en ekte pasient. Ifølge Jeffries' simuleringsteori (Jeffries, Rodgers \& Adamson, 2015) er dette en aktiv læringsform som forutsetter høy grad av kunnskap og deltakelse, samarbeid, refleksjon og feedback. Det er tett student-lærer-interaksjon og høy «time-on-task» (Prater, 1992), det vil si at det meste av tiden brukes på å være aktivt engasjert i selve læringsoppgaven.

Simulering kan også beskrives som en form for situert læring, altså læring som foregår via aktivitet i den konteksten kunnskapen skal brukes (Lave \& Wenger, 1990). For studentene blir det en mester-svenn-situasjon hvor ferske deltakere ser og lærer av de erfarne. De får selv prøvd seg i en realistisk situasjon - en smakebit av sitt fremtidige yrke. I dette prosjektet var noen av studentene markører for foreldre og pårørende. Disse fikk anledning til å leve seg inn i klientens perspektiv. 
For de profesjonelle er simulering en horisontal læringssituasjon hvor man øver og reflekterer som likeverdige deltakere i en konkret, relevant situasjon, og hvor nye innsikter kan oppstå fordi man blander ulike erfarings- og kunnskapsfelt. Li (2017) beskriver horisontal læring som vanlig og hensiktsmessig når lite beskrevne teknologier eller praksiser skal finne sin form. Omsorgsovertakelse ved fødsel er lite beskrevet.

Simuleringsmetodikken vektlegger likeverdighet i selve læringssituasjonen. Det betyr at alles erfaringer og innspill ses på som potensielt lærerike. Selv om deltakerne ellers inngår i et hierarki av posisjoner, møtes de i simuleringen på like fot i forsøket på å løse felles oppgaver bedre og øke egen kompetanse. De lærer om og av hverandre.

Et akutt inngrep fra barnevernet ved fødsel har noen fellestrekk med oppdragene til rednings- og nødetater. I disse tjenestene er det vanlig å øve seg i virkelighetstro scenarioer, blant annet etter metoden medisinsk simulering og Crisis Resource Management (CRM) (Rall \& Dieckmann, 2005). Metoden ble utviklet for å bøte på mangler i medisinsk utdanning, særlig undervisning og trening i å arbeide i tverrfaglige team.

SIMInnlandet (2019), senter for simulering og innovasjon i psykisk helsevern, har overført metodikken til krevende situasjoner i psykisk helsevern. Senteret tilbyr praksisnær trening for helse- og omsorgsfagstudenter. Innholdet i simuleringen handler ofte om akutte eller særlig vanskelige situasjoner, men kan også legges opp til trening på det dagligdagse, for eksempel samtaler med barn eller et første klientmøte og inntakssamtale. Det kan legges opp som individuell ferdighetstrening eller trening på samhandling i et team eller tverrfaglig samarbeid. De som trener sammen, er de som ellers ville ha samarbeidet dersom situasjonen oppsto i virkeligheten. Uansett skal deltakerne møte situasjoner som oppleves realistiske og passe utfordrende. Treningen forventes å gi $ø$ kt handlingskompetanse, faglig og kritisk refleksjon og forbedring av den konkrete praksis det øves på. En evaluering av læringsresultater ved bruk av simulering bør også omfatte deltaker- eller studenttilfredshet og selvtillit i forhold til fag og oppgave (Jeffries et al., 2015).

Til forskjell fra rollespill opptrer simuleringsdeltakerne, bortsett fra markørene, som seg selv som fagperson. I studentsimulering øver studentene på situasjoner i sin fremtidige yrkesrolle eller, som her, som student i 
praksis i en barneverntjeneste. Simuleringen forberedes ved å rette søkelyset mot en ferdighet, oppgave eller situasjon som man ønsker å trene på. Så defineres læringsmål, og et egnet scenario utvikles. Som forberedelse til treningen - prebrifing - setter deltakerne seg inn i eksisterende kunnskap om tematikken. Markørene, det vil si personene som i vårt tilfelle spiller nybakte foreldre eller pårørende i scenarioet, forbereder seg på rollen og hvordan vanskegraden for de profesjonelle kan reguleres. Før selve treningsøkten starter, gjennomgås scenarioet i en såkalt brifing. Den som leder scenariotreningen, kalles fasilitator, og de som deltar i scenarioet, beskrives som aktører. Kollegaer og medstudenter som ikke er involvert i scenarioet, deltar som observatører med spesifikke observasjonsoppgaver.

Etter endt simulering møtes alle til debrifing, det vil si en strukturert samtale i lys av læringsmålene. Aktørene reflekterer over utfordringer i scenarioet, hva som gikk bra, og om noe kunne vært gjort annerledes. Debrifingfasen avrundes med at samtlige deltakere konkretiserer hva de har lært av simuleringen, og hvordan dette kan omsettes i handling på arbeidsplassen.

\begin{tabular}{ccccc} 
UTVIKLE & PREBRIEF & BRIEFING & SIMULERING & DEBRIEF \\
SCENARIO & Gjennomgang & Gjennomgang & Gjennomføre/ & Strukturert \\
Hendelsesforløp & av relevant & av scenario, & trene på det & refleksjon rundt \\
og læringsmål & forkunnskap & roller og & beskrevne & opplevelse og \\
& oppgaver & scenariet & læringsmål \\
\hline
\end{tabular}

Figur 1. Gangen i en simulering.

\section{SIM spedbarnevern og foreldrestøtte - tverrfaglig læring i akutte, sårbare situasjoner}

Hendelsesforløpet i de enkelte scenarioene ble utviklet sammen med en tverrfaglig gruppe av fagfolk. Studentene fikk presentert scenarioene på forhånd og meldte seg frivillig til å være enten markør eller observatør. Undervisningsdelen, prebrifingen, ble levert i form av et E-læringskurs om omsorgsovertakelse ved fødsel. Studentene fikk også undervisning om etikk, makt og kommunikasjon og innføring i bruk av digital historiefortelling som metode (Jamissen, Hardy, Nordkvelle \& Pleasants, 2017). 
Studentmarkørene skulle leve seg inn i rollen som nybakt forelder med problemer, som venn eller som pårørende. Studenter i observatørrollen hadde som oppgave å gi tilbakemeldinger til de profesjonelle i tråd med læringsmålene, altså oversette og binde sammen simuleringens teoretiske mål og det som konkret utspilte seg i scenarioet. I tillegg observerte de fra henholdsvis barnets, foreldrenes eller de profesjonelles perspektiv. Fagfolkene kjente ikke scenarioene i detalj før selve treningen tok til, for å bevare realismen i en ekte situasjon. Hver simuleringsøkt varte i $2 \frac{1}{2} 2$ time.

Det overordnede læringsmålet for alle scenarioene var å forberede og gjennomføre omsorgsovertakelse på en rettssikker, faglig forsvarlig og ivaretakende måte. Delmålene var å trene på:

- tydelig og ivaretakende kommunikasjon med foreldre

- tverrfaglig samarbeid med respekt for ulike roller og mandat

- trygg ivaretakelse av barnet

- faglig og etisk refleksjon i pressede situasjoner

Ett av scenarioene beskrev hendelsesforløpet i en akutt separasjon av foreldre og nyfødt barn på barselavdelingen. Vedlegg 1 viser hvordan scenarioet ble presentert.

\section{Forskning og fremgangsmåte}

Forskningen er lagt opp som kvalitativ aksjonsforskning (Høie, 2010) hvor simuleringen, påfølgende erfaringskonferanse og innspill fra prosjektets referansegruppe bidrar til å identifisere problem- og forbedringsområder og praksisutvikling. Deltakere ga informert, skriftlig samtykke til at refleksjonsfasen, studentenes refleksjonsnotater og deltakernes evaluering kunne brukes i forskningsøyemed. Hovedvekten av resultatene som presenteres her, er fra refleksjonsnotatene til studentene. Studien er godkjent av NSD - Norsk senter for forskningsdata. Refleksjonsfasen, eller avsluttende debrifing i simuleringsprosedyren, ble brukt som fokusgrupperefleksjon (Morgan, 1997). Til sammen 30 grupper med 12-16 deltakere diskuterte (i gjennomsnittlig 50 minutter) læringsmål og det som skjedde i scenarioene. Simuleringen og datainnsamlingen ble gjennomført over tre dager og ved flere lokasjoner i 2018 og 2019. 
Studentene hadde ikke hatt noe forutgående praksis, og deres uttalelser må forstås på bakgrunn av den undervisningen de har hatt i løpet av to år på barnevernstudiet. Forfatterne deltok som praktiske tilretteleggere og fagstøtte under simuleringen, en rolle som har mye til felles med deltakende observasjon (Fangen, 2010).

\section{Deltakere}

Til sammen 174 andreårsstudenter ved bachelorstudiet i barnevern deltok som en del av den obligatoriske undervisningen. Etter invitasjon deltok til sammen 110 fagpersoner fra spesialisthelsetjeneste og kommunale helse- og omsorgstjenester. Studenter og fagfolk ble delt inn i 30 simuleringsgrupper sammensatt av personer som naturlig ville ha samarbeidet på grunn av geografi eller henvisningsrutiner. Scenarioenes sentrale problemstillinger og læringsmål ble tilpasset tjenestenes funksjon og oppgaver.

For å synliggjøre hvor mange tjenester som kan bli involvert i barnevernarbeid i nyfødtperioden, lister vi opp alle som deltok: barnevernspedagoger, barnepleiere, sykepleiere, jordmødre, psykologer, kliniske pedagoger og sosionomer. Disse jobbet i barneverntjenester, interkommunal barnevernvakt, Bufetats barne- og familiesenter, føde- og barselavdelinger, psykisk helsevern ved BUPs sped- og småbarnsteam og behandlingsenheter for gravide og sped- og småbarnsforeldre innen tverrfaglig spesialisert behandling (TSB) for avhengighetsproblematikk, kommunale lavterskeltilbud for sped- og småbarnsfamilier, jordmor- og helsestasjonstjeneste. I tillegg deltok åtte fageksperter, de fleste lærere på barnevernutdanningen, seks sertifiserte fasilitatorer, fem teknikere for lyd og bildestyring og de to prosjektansvarlige (forfatterne).

\section{Kryssende verdier og verdien av godt samarbeid}

Deltakerne i «SIM spedbarnevern og foreldrestøtte» møttes for å øve på en situasjon hvor det er motstridende interesser, potensielt høy temperatur og dels kryssende verdier. Aktørene i scenarioet ble utfordret til å samarbeide og ta verdivalg under tidspress og «trykket» av sterke følelser. 
I alle scenarioene var de ulike posisjonene og handlingsforløp(beskrevet i kapittel 7) representert: «det medisinske, psykososiale og barnevernfaglige handlingsforløpet». Selv om dette kun var en treningssituasjon, observerte noen av studentene spenninger mellom tjenester. Deltakerne, studenter og profesjonelle erfarte at ulike yrkesgrupper ikke alltid kjenner godt nok til andres mandat og arbeidsoppgaver. En student kommenterte at det var tydelige utfordringer i forhold til samarbeidet mellom jordmor og barnevernet, og sa: «Det kommer relativt tydelig frem i hvordan scenarioet spiller seg ut, at det ikke er så mye samarbeid mellom de ulike rollene, jordmor og barneverntjenesten.» En annen sa: «Det er interessant å se og observere her, at de ulike yrkesgruppene ikke kjenner godt nok til hverandres oppgaver og mulighet til oppfølging av familier og barn.»

Studenter registrerte at oppgaven var vanskelig, selv for erfarne fagfolk, og en sa: «Det var fint å se at de også ga utrykk for at de var nervøse og synes det var vanskelig». En observasjon som muligens kan skape ydmykhet for oppgaven og aksept for usikkerhet hos både en selv og andre. Det kan også gjøre en fremtidig barnevernspedagog bekymret for å gå inn i yrket.

Studentene så og fagfolkene erfarte hvordan aktørene kommuniserte med utgangspunkt i ulike mandat og roller, og hvordan de i etterkant reflekterte over egen rolleutøvelse i det tverrfaglige samarbeidet: «Jeg opplevde det som spesielt nyttig å se, helt konkret, hvordan erfarne fagfolk ter seg i en presset situasjon, og etterpå høre hva de var opptatt av å få til eller trekke frem i løpet av møtet med foreldrene.»

I likhet med de fleste deltakerne, trekker denne studenten frem refleksjonsfasen, drøftingen i etterkant av simuleringen, som særlig verdifull. Den ga ytterligere innblikk i barnevernets omsorgsvurderinger og tiltak, og ulike samarbeidsparters arbeidsformer og lovverk. Studentene deltok selv i den tverrfaglige refleksjonsprosessen med sin ferske, teoretiske kunnskap.

Tjenestene ble bedre kjent med hverandres arbeidsformer og så hvordan samarbeidsparter kan utfylle hverandre for å skape en bedre situasjon for foreldre og barn. Flere studenter trekker frem jordmødrenes omsorgsfulle væremåte, og deres blikk for det normale i barselsituasjonen, selv om foreldrene var problembelastet og barnevernet var involvert: 
Jordmødrene viste ... mye varme og ro fra første stund, noe som var med på å skape mye trygghet i en ellers vanskelig situasjon. De stilte spørsmål til både meg, far og storesøster om hvordan vi hadde det, hvordan fødselen hadde vært, og hvordan formen var. Da de stilte spørsmål som dette, følte jeg på at de virkelig brydde seg om meg som mor og hvordan jeg hadde det, og det føltes veldig betryggende.

I rollen som mor sa en student at: «Det var fint å få litt ulik tilbakemelding fra jordmor, BUP og barnevern. Det viste at vi jobber ulikt, men at vi alle har et felles mål, og det er barnets beste.»

Tilbakemeldingene fra fagfolkene var rettet mot muligheten simuleringen ga til å bli kjent med og lære sammen med andre yrkesgrupper og tjenester, og at det var «fint å bli kjent med de andre sin rolle og få snakket prosess i etterkant sammen med de involverte.» De profesjonelle understreket at «dette er krevende og komplekse saker hvor mange er involvert, og det er viktig å øve sammen for en felles forståelse».

De profesjonelle vektla verdien av å møtes for å øve på noe veldig vanskelig - på like fot. At det var virkelighetsnært, men ikke virkelig syntes å fristille fagfolkene fra sine sedvanlig posisjoner. De utforsket $\mathrm{i}$ fellesskap, og flere snakket om dette vanskelige temaet med sine samarbeidspartnere for første gang.

Simuleringens nøytrale grunn, klare struktur og fasilitators sikring av likeverdig deltakelse gjorde det kanskje lettere å snakke om verdier og holdninger og å tematisere vanlige spenninger mellom tjenester. Det er grunn til å tro at trening kan bidra til å redusere verdikonflikter ved at deltakerne forstår hverandres mandat og rammebetingelser bedre, og ved at de har møttes og løst oppgaver sammen.

\section{En forberedelse på yrke og fremtidige hendelser}

Det ser ut til at tverrfaglig simulering ga studenter en erfaring med tverrfaglighet som ga knagger å henge skolekunnskapen på. De fikk nærkontakt med tjenester de skal samarbeide med i fremtiden. Flere av studentene opplevde simuleringen som et steg nærmere sitt fremtidige yrke, og for noen var det alvorlige innholdet i scenarioene en øyeåpner: «Det var først 
ved denne simuleringen jeg virkelig tenkte over at den utdannelsen jeg tar ikke bare er en dans på roser, men at man også er ganske sårbar.»

Mange sa at simuleringen ga erfaringer som de vil ta med seg videre $\mathrm{i}$ studiet og en fremtidig yrkesutøvelse: «Dette er noe jeg kommer til å ha med meg alltid, og bruke når jeg skal møte andre, om ikke i samme situasjonen, men generelt.»

De av studentene som agerte som barnevernstudent i praksis, fikk prøvd ut hva de hadde lest og lært. De som var markører for foreldre, kjente erfaringene både kroppslig og følelsesmessig.

Jeg tror denne opplevelsen vil gjøre det lettere for meg i lignende arbeid i fremtiden, da jeg selv fikk kjenne på hvordan det føltes når jordmødrene snakket til meg med trygghet og varme og ikke tok fra meg håpet.

Mange reflekterte over hvordan forelesninger og lesing av pensum gir nødvending teoretisk kunnskap, men at simuleringen ga dem mulighet til å koble mellom teori og praksis.

Takket være undervisningen har jeg hatt forståelse for teoriene som ligger bak, men jeg har ikke hatt mye erfaring med hvordan vi i praksis skal ta i bruk kunnskapen og teknikkene vi har lært.

Faglig selvtillit handler blant annet om å kjenne seg rustet for jobben ved å forstå ulike situasjoner og ha et handlingsrepertoar tilgjengelig. Spørreskjemaevalueringen fra både studenter og fagfolk viste at 95 prosent mente at simuleringstreningen kunne bidra til å bli tryggere i vanskelige jobbsituasjoner. Omtrent like mange svarte at refleksjonsfasen (debrifingen) ga verdifulle innspill til både arbeid og studie. Studentene plukket opp tips og laget seg forestillinger om hvordan de vil samhandle i fremtiden:

Det å ha rom for å utveksle erfaringer og få stille spørsmål på tvers av yrkene er også viktig. Det å ha en felles evaluering i etterkant av en slik situasjon er nødvendig for alle involverte, familie som profesjonelle.

De profesjonelle fikk en faglig krevende treningsoppgave der og da, eller som en av dem sa: «Det gjør noe med en innvendig og følelsesmessig å delta i en slik krise, og alle ønsker å håndtere det på best mulig måte og fremstå som profesjonelle i sin rolle.» 
Deltakerne beskriver situert læring (Lave \& Wenger, 1990), erfaringsbasert forståelse og samspill mellom teoretisk og praktisk innsikt. Simuleringen ga tanker om hva det vil si å være barnevernspedagog og om yrkets krevende sider. De fikk innsikt i samarbeidsparters oppgaveforståelse og en beredskap for fremtidige hendelser.

Vi kan ikke vite om antakelsene om å være forberedt gir økt trygghet når ferdighetene skal brukes. Men - det er dokumentert at praktiske øvelser øker sannsynligheten for riktige handlinger i en opphetet situasjon (Rall \& Dieckman, 2005).

\section{Refleksjon, respekt og ulike perspektiver}

Det å ha kjent på klientens opplevelse i markørrollen kan gi større ydmykhet og varhet for hvor lett man kan trå feil, og hvordan den profesjonelles posisjon og makt kan oppleves. Det er en potent mentaliseringsøvelse - å forsøke å forstå den andre innenfra og å se seg selv og egne handlinger med den andres blikk (Allen, Fonagy \& Bateman, 2008). Evnen til å skifte perspektiv, forstå egne bidrag i samhandlingen og anerkjenne at alle deltakere er sentrum i sitt eget opplevelsesunivers, er viktige egenskaper i både klientarbeid og tverrfaglig samhandling, eller slik en student uttrykker det:

Jeg sitter igjen med en bredere forståelse av hvordan det kan oppleves å være forelder i en akuttvedtak-situasjon, men også et innblikk i hvor utfordrende det kan oppleves å være ansatt i barneverntjenesten og/eller jordmor/barnepleier i et slikt scenario.

Inngrepets alvorlighet - å hente et nyfødt barn fra foreldrene - gjør det tydelig for deltakerne at de holder en viktig del av andres liv i sine hender, som Løgstrup (2010) sier det. Ved siden av faglige og juridiske forpliktelser har de profesjonelle også et moralsk ansvar. De må reflektere seg frem til hva som er best for barnet og foreldrene, og hvilken verdi som skal veie tyngst. Skal de gi håp til foreldre om å få beholde barnet? Er det riktig å holde tilbake opplysninger eller være nådeløst ærlig?

Noen mente at denne typen fokus på det positive (eller optimisme) ville gi falske forhåpninger hos foreldrene, og at dette ville skape en type vrangforestilling 
hos foreldrene med tanke på deres muligheter for å få tilbake omsorgen for barnet. Andre, blant annet jeg selv, mente at denne typen optimisme var avgjørende for foreldrene i en slik situasjon.

Flere av markørene for moren som mistet barnet, levde seg så inn i rollen at de følte ekte fortvilelse. De fortalte i debrifingen av de var så sterkt følelsesmessig aktivert at de ikke husket hva fagfolkene sa: «Her kan vi studenter få føle på det reelle og seriøse i en slik setting, som kan være vanskelig å se for seg kun ved å lese pensum eller høre på forelesning.»

Både studenter, lærere og fagfolk oppdaget ting de stilte spørsmål ved, og som satte i gang ideer om behov for praksisforbedring, for eksempel:

Et tema som ble mye diskutert, var oppfølging i etterkant av omsorgsovertakelser ved fødsel. I denne diskusjonen kom det frem at verken de ansatte på fødeavdelingen eller andre involverte parter får noen form for debrifing eller oppfølgende samtaler i etterkant av omsorgsovertakelsen.

En lærer mente at simuleringstreningen avdekket behov for mer kunnskap og endringer i undervisningsopplegget: "Jeg lærte mye selv, og ble oppmerksom på mange ting vi bør gå videre på, ting vi burde ta opp i undervisningen, og problemstillinger det burde forskes mer på.»

Simuleringsmetodikkens sterke vektlegging av refleksjon gjorde studentene delaktige og bidro til å styrke studentenes faglige blikk og øke deres rolleforståelse, som et viktig bidrag i arbeidet med å bli en bedre barnevernspedagog. Både fagfolk og studenter opplevde seg dradd inn i scenarioet som om det var virkelig, det ga engasjement, vekket ettertanke og stimulerte til kritisk refleksjon. Den tverrfaglige simuleringstreningen utforsket og konstaterte verdien av godt samarbeid og håndterte ulike profesjoners posisjoner og kryssende verdier i arbeidet med omsorgsovertakelse ved fødsel, og slik sett bekreftes metoden som velegnet til å identifisere og håndtere verdikonflikter.

\section{Likeverdig deltakelse i et faglig fellesskap}

Opplegget var klart strukturert og ledet av fasilitator. I tråd med voksenpedagogiske prinsipper og simuleringsmetodikken stilte alle deltakerne på like fot. Simulering er virkelighet "på liksom», slik barn leker. Selv 
om scenarioet var svært alvorlig og følelsesladd, er det ingen som blir skadd "på ordentlig», og i prinsippet er det ingen som er låst i bestemte posisjoner. Alle deltar for å «leke» og lære. Slike arenaer er det få av i virkeligheten.

Mange studenter ga uttrykk for at de følte seg likeverdige med de profesjonelle i diskusjonen, at disse var interessert i å høre deres synspunkter, noe som ga studentene opplevelsen av å bli inkludert og tatt på alvor. Dette er også en etisk dimensjon og en sentral verdi som kan motvirke spenninger i tverrfaglig praksis.

Alle fikk komme til orde og ytre sine meninger uten at de ble avbrutt eller motsagt. Anerkjennelse var nok den atmosfæren jeg kjente sterkest i rommet, noe som betyr mye for en student under læring. Jeg følte meg ivaretatt, og turte å si mine meninger og sette ord på de følelsene jeg satt med da jeg var i en av de utsattes sko.

Studentene fikk bekreftelser på at de selv satt med viktig kunnskap som de kunne dele med fagfeltet, og som åpenbart styrket deres selvtillit: «Jeg mener at vi har mye å lære av profesjonene, men de kan også lære av oss.»

Simuleringen ga «knagger» de kunne henge sine teoretiske innsikter på. Kunnskap som er følt, tenkt og gjort, lagres sterkere enn det som kun er lest og tenkt, mente denne studenten:

Personlig lærer jeg mer av å se og oppleve samt reflektere enn å lese og lytte. Om noe skal huskes, kan det ikke bare leses, det må forstås. På den måten kan man begrunne det man gjør, og valgene man tar, da det ligger erfaringer i bakgrunn av valgene.

Betydningen av anerkjennelse og trygghet til å komme med egne tanker er en viktig forutsetning for læring og en inspirasjon til videre vekst og deltakelse. Lærerne ble imponert over egne studenter, og over hvordan de bidro i diskusjonene som markører og observatører. De kommenterte engasjementet studentene viste, og uttrykte glede for at de ble så godt tatt imot og inkludert. En av lærerne understreket betydningen av at samarbeidet handlet om et så vanskelig tema som omsorgsovertakelse ved fødsel, og som fagfeltet har lite erfaring med. 
Det ble en likeverdighet mellom oss alle hvor vi gikk sammen for å forsøke å hjelpe disse barna og familiene. Det ble et moralsk fellesskap, et moralsk felles ansvar for å hjelpe disse familiene, som vi opplevde sterkt. Og det ble veldig levende for oss, selv om det bare var simulering.

I tråd med horisontal læring ( $\mathrm{Li}, 2017)$ beskrives dette sammensatte læringsfellesskapet som delende og kreativt. Ikke bare kombinasjonen av ulike yrkesgrupper, men også av studenter og erfarne praktikere som stimulerte til nytenkning og opplevelsen av likeverd.

Flere av studentene understreket at de ikke ville ha hatt samme læringsutbytte i rene studentrollespill.

Det var lærerikt å jobbe sammen med profesjonelle yrkesutøvere som kunne jobben sin, og ikke bare studenter som prøvde seg frem. Vi fikk se ulike sider av fagfeltet, og hva vi eventuelt må gjøre i en situasjon som casen vi fikk utdelt.

Fagfolkene bekrefter at de satte pris på studentenes bidrag i diskusjonene og som markører. De syntes at studentene var godt forberedt til sine markørroller. En av dem takket studentene og sa at «de gjorde en troverdig og proff innsats» som gjorde simuleringen mer realistisk for fagfolkene. Mange av fagfolkene trakk frem viktigheten av å bli kjent med hverandre gjennom å øve sammen. Til tross for scenarioets realistiske alvor syntes det som om simuleringen ga lignende frihetsgrader og spillerom som utforskende lek har.

\section{Simulering som tverrfaglig øvelse $\mathrm{i}$ inngripende barnevernsituasjoner}

Stigens (1979) definisjon av verdier som de ting som gir innhold i tilværelsen, gjør det lett å se det verdiladde i omsorgsovertakelse ved fødsel. Det er få «ting» som oppfattes som mer meningsbærende og verdifullt enn et nyfødt barn. En familieforøkelse skaper et dypt innhold i tilværelsen, og en uventet separasjon like etter fødsel griper inn i verdien vi tillegger familie, samvær, kjærlighet, omsorg, fremtid. I det norske samfunnet veier verdien av et barns liv og helse og en trygg barndom likevel sterkere enn verdien av å være sammen som familie. 
Barnevernets mandat er å gripe inn for å verne om barnets ubestridte verdi samtidig som andre hensyn og interesser må balanseres. Arbeidet griper inn i samfunnets kjerneverdier, i hvem og hvordan vi ønsker å være, i familie- og foreldreidealer og ideer om den gode barndom. Tjenesten opererer $i$ et spenningsfelt mellom det offentlige og private. Familien blir vurdert ut fra rettslige og faglige standarder, og prinsippet om barnets beste skal ivaretas i beslutninger som berører det enkelte barn. Hva som er til barnets beste, er styrt av livssyn, verdier og de konkrete situasjonene hvor avgjørelsen tas. Det er få objektive sannheter, og man kommer ikke utenom «skjønnets byrde».

Drøftinger i etterkant av simuleringen ga deltakerne innblikk i barnevernets omsorgsvurderinger og tiltak. Profesjonene viste forståelse og respekt for hverandres kunnskap og mandat. Men dialogen og refleksjonene i etterkant utfordret også profesjonenes og studentenes vurderinger av foreldre og barns behov ut fra de enkelte scenarioene. Temaer som ble diskutert, var samtykke og tverrfaglig samarbeid tidlig i svangerskapet for å kunne tilrettelegge for planlagt omsorgsovertakelse eller forebygge seperasjon av mor og barn ved fødsel.

Man kommer heller ikke utenom at flere tjenester må arbeide sammen for å oppfylle barnevernets samfunnsmandat. Hele tjenesteapparatet er bemannet av individer som har sine egne personlige oppfatninger av hva som er akseptabelt og uakseptabelt. Å komme i posisjon og sette et godt tverrfaglig samarbeid allerede i svangerskapet er krevende på grunn av juridiske og formelle skranker og avstand og manglende eller negative erfaringer med tverrprofesjonell samhandling. At saksfeltet er svært verdiladd, gjør spenningene sterke, med fare for å true selve kjernemandatet: å ivareta barnets beste. Praksisanbefalinger for psykisk helsevern i perinalperioden fremhever betydningen av et tverrprofesjonelt samarbeid (Brockington, Butterworth \& Glangeaud-Freudenthal, 2017).

Ulike fag og tjenester har kunnskap om forskjellige sider av problemene og behovene og rår over ulike metoder og tiltak. Når samarbeidet glir godt, vil sannsynligvis både avgjørelser og tiltak bli bedre. Men like ofte oppstår spenninger og konflikter i den tverrprofesjonelle samhandlingen, om samarbeidet i det hele tatt kommer i gang. Det samme dokumenteres i en stor evaluering av engelsk barnevern. Munro (2011) 
beskriver spenninger mellom tjenester - og særlig mellom barnevernet og de øvrige hjelpetjenester - som en sentral årsak til at barn og familier ikke får tilstrekkelig hjelp. Lignende konklusjoner har kommet fra en rekke norske rapporter og tilsyn som påpeker at kommunikasjon og samhandling mellom tjenester og nivåer er for dårlig, for eksempel NOU, 2017: 12 og Fylkesmannen i Hordaland, Rogaland og Troms (Fylkesmannen, 2016).

«SIM spedbarnevern og foreldrestøtte» ga studenter og fagfolk anledning til å trene på å gjennomføre akutte, verdiladde og potensielt konfliktskapende barnevernintervensjoner. Alle var relatert til spedbarnevern, foreldrestøtte og separasjon ved fødsel. Valg av omsorgsovertakelse ved fødsel som tematikk ga studenter og fagfolk erfaring med en sjelden og inngripende situasjon som utfordret det tverrfaglige samarbeidet. Den tverrfaglige simuleringstreningen inkluderte drøftinger av barnevernets omsorgsvurderinger og tiltak, ulike samarbeidsparters arbeidsformer og lovverk og hvordan man kan komme til en felles forståelse av barnets behov og situasjon. Det ga fagfolk og studenter mulighet til å snakke sammen med utgangspunkt i et konkret hendelsesforløp som alle var involvert i. De drøftet hverandres fag og verdier i arbeidet med å utvikle tverrfaglig praksis for bedre ivaretakelse av foreldre og barn, slik det oppfordres til i blant annet stortingsmeldingen «Utdanning for velferd - samspill i praksis» (Kunnskapsdepartementet, 2012, s. 40). Prosjektet var begrunnet i spørsmål om hvordan vi kan forberede studenter på sitt fremtidige yrke, særlig kompleksiteten i tverrfaglig samarbeid. Det var også et tilbud til praksisfeltet om å møtes på «nøytral grunn» for å utforske, øve og lære sammen og slik forebygge konflikter og bidra til bedre profesjonell og tverrfaglig praksis. Deltakerne beskrev simuleringen som realistisk, engasjerende og alvorlig, men ingenting alvorlig kunne hende «på ekte». Opplevelsen av en ekte situasjon ble forsterket hos studentene ved at det var profesjonelle som øvde i sine roller. Studentmarkørene ga samtidig økt realisme i treningen for de profesjonelle, og for studenten ga det et unikt innblikk i hvordan det er å være på klientsiden i en tøff barnevernsituasjon.

Fagfolkene bød på seg selv i en krevende situasjon som mange ikke hadde tidligere erfaring med. De profesjonelle ble samtidig «satt på strekk» - og noen inntil det ubehagelige. Erfaringen understreker 
viktigheten av å etablere scenarioer som er passe utfordrende med gode mestringsmuligheter.

Når teoretisk kunnskap kobles til praksis i en realistisk setting, blir læringen relevant (Lave \& Wenger, 1990). Når den som skal lære, er følelsesmessig og intellektuelt engasjert, er det mer givende å lære, og læringen sitter bedre. Når dette skjer i en atmosfære av respekt, alvor og refleksjon, antar vi at det utvikles ydmykhet og klokskap.

Simuleringsstruktur, fasilitering og sterk vektlegging av likeverdig deltakelse i felles læring så ut til å etablere en trygg arena for både profesjonelle og studenter. Med referanse til mentaliseringsteori (Allen \& Fonagy, 2006) kan man anta at det er vanskeligere å avskrive eller opptre uetisk overfor den andre når man har forsøkt å se verden fra dennes perspektiv. Denne dimensjonen forsterkes når man forstår hvordan egne handlinger og holdninger påvirker andre, når man klarer å se seg selv utenfra med den andres blikk. Dette gjorde det lettere for deltakerne å se ting som ellers kan passere uoppdaget - på en arena hvor deltakerne kan lære av hverandre gjennom å dele fokus og holdninger til problemet som diskuteres, og uten at noen tar skade.

Det er behov for utvikling av læringsmetoder som kobler sammen studier og praksis, og som gir studenter og fagfolk anledning til å forberede seg på virkelige, vanskelige og sjeldne situasjoner uten at noen tar skade. 97 prosent av evalueringene svarte at simulering bør benyttes mer som fagutvikling og trening i å takle sjeldne, kompliserte og uforutsigbare situasjoner hvor sterke følelser og reaksjoner ofte spiller seg ut.

De to rundene med simulering involverte mange personer i et komplisert og ressurskrevende rigg. Et alternativ til å videreføre prosjektet i denne formen kan være å prøve ut VR-basert («virtual reality») simulering hvor scenarioet spilles inn i 360-graders film. Da kan simuleringsmetodikken gjennomføres på studiestedet eller arbeidsplassene. Det vil spare tid og ressurser, men opplegget mister en del elementer som våre deltakere satte stor pris på, som kombinasjonen av studenter og fagfolk, å se hvordan erfarne fagfolk løser situasjonen etter hvert som den utvikler seg, og verdien av å trene og lære i en annen setting enn jobben eller skolen. Samtidig vil et enklere treningsopplegg med VR-briller gi rom for hyppigere simulering med flere scenarioer. 
Selv om erfaringer og tilbakemeldinger fra dette pilotprosjektet var overveiende positive, er det fortsatt lite forskningsbasert kunnskap om effekten av simulering på trening av ikke-tekniske ferdigheter. Dette prosjektets forskningsmessige design tilpasset fag- og metodeutvikling har begrensninger ved at forfatterne både utviklet og hadde roller i simuleringen og så evaluerte prosjektet. En styrke var at studentene ble deltakere i både undervisning og forskning. Det er imidlertid behov for flere erfaringer og mer forskning for å kunne si hvordan simulering bidrar til økt bevissthet om og bedre håndtering av verdikonflikter i tverrfaglig samarbeid. Det trengs også mer kunnskap om simulering som læringsform i både utdanning og praksis.

\section{Om prosjektet}

Dette forskningsarbeidet er gjennomført med økonomisk støtte fra Høgskolen i Innlandets stimuleringsmidler for samarbeid med praksisfeltet, Sykehuset Innlandet, Divisjon Psykisk helsevern og Norges forskningsråd (HELSEVEL). SIMInnlandet, SI HF og Kringsjåtunet ungdomspsykiatriske behandlingssenter SI HF bidro med fasilitatorer.

\section{Litteratur}

Allen, J. G., Fonagy, P. \& Bateman, A. W. (2008). Mentalizing in clinical practice.

Washington, DC: American Psychiatric Publishing, Inc.

Brockington, I., Butterworth, R. \& Glangeaud-Freudenthal, N. (2017). An international position paper on mother-infant (perinatal) mental health, with guidelines for clinical practice. Archives of Women's Mental Health, 20(1), 113-120. https://doi.org/10.1007/s00737-016-0684-7

Bufdir. (2018). Kartlegging av kompetansebehov i det kommunale barnevernet. Hentet fra https://www.bufdir.no/nn/Bibliotek/Dokumentside/?docId=BUFoooo4452

Bufdir. (2019). Utredning av kompetansehevingstiltak i barnevernet. Hentet fra https://www.bufdir.no/Bibliotek/Dokumentside/?docId=BUFoooo5020

Dyrhaug, T. (2019). Personlig e-postkommunikasjon med statistikkavdeling i Statistisk sentralbyrå (SSB), mottatt den 12.07.2019. https://www.ssb.no/barneverng

Fangen, K. (2010). Deltagende observasjon (2. utg.). Bergen: Fagbokforlaget.

Freel, M. (2010). Baby K's unlawful removal: Practice issues in the emergency protection of children. Child Abuse Review, 19(3), 158-168. https://doi.org/10.1002/car.1107 
Fylkesmannen. (2016). Dei forsto meg ikkje. (Tilsynsrapport fra Fylkesmennene i Hordaland, Rogaland og Troms). Hentet fra https://www.fylkesmannen.no/ contentassets/21c2006e3f3d45918321coo6a5a370e7/dei-forsto-meg-ikkje--tilsynsrapport.pdf

Gaba, D. M. (2004). The future vision of simulation in health care. Quality and Safety in Health Care, (13), 2-10.

Grimen, H. (2008). Profesjon og tillit. I A. Molander \& L. I. Tenum (Red.), Profesjonsstudier (s. 197-215). Oslo: Universitetsforlaget.

Høie, M. (2010). Aksjonsforskning. I E. Arntzen \& J. Tolsby (Red.), Studenten som forsker i utdanning og yrke (s. 154-166). Lillestrøm: Høgskolen i Akershus.

Jamissen, G., Hardy, P., Nordkvelle, Y. \& Pleasants, H. (2017). Digital storytelling in higher education. International perspectives. London, England: Palgrave Macmillan.

Jeffries, P. R., Rodgers, B. \& Adamson, K. (2015). NLN Jeffries simulation theory: Brief narrative description. Nursing Education Perspectives, 36(5), 292-293.

Kunnskapsdepartementet. (2012). Utdanning for velferd - samspill i praksis (Meld. St. 13 (2011-2012)). Hentet fra https://www.regjeringen.no

Kunnskapsdepartementet. (2017). RETHOS: Retningslinjer for helse- og sosialfagutdanningene. https://www.regjeringen.no

Kunnskapsdepartementet. (2019). Forskrift om nasjonal retningslinje for barnevernspedagogutdanning (FOR-2019-03-15-398). Hentet fra https://www. lovdata.no

Lave, J. \& Wenger, E. (1990). Situated learning: Legitimate periperal participation. Cambridge, England: Cambridge University Press.

Li, P. (2017). Horizontal learning. I H. Bathelt, P. Cohendet, Henn, S. \& L. Simon (Red.), The Elgar companion to innovation and knowledge creation (s. 392-404). Gloucestershire, England: Edward Elgar Publishing.

Løgstrup, K. E. (2010). Den etiske fordring (4. utg.). Århus: Klim.

Morgan, D. L. (1997). Focus groups as qualitative research (2. utg.). Thousand Oaks, CA: Sage Publications.

Munro, E. (2011). The Munro review of child protection: Final report. A child-centred system. Hentet fra https://assets.publishing.service.gov.uk/government/uploads/ system/uploads/attachment_data/file/175391/Munro-Review.pdf

Nordby, H. (2017). Konflikthåndtering for ledere. Oslo: Gyldendal Akademisk.

NOU 2017: 12. (2017). Svikt og svik - Gjennomgang av saker hvor barn har voert utsatt for vold, seksuelle overgrep og omsorgssvikt. Hentet fra https://www. regjeringen.no/contentassets/a44ef6e251cd443396588483e97402ab/no/pdfs/ nou20172017001200odddpdfs.pdf

Prater, M. A. (1992). Increasing time-on-task in the classroom: Suggestions for improving the amount of time learners spend in on-task behaviors. Intervention in School and Clinic, 28(1), 22-27. 
Rall, M. \& Dieckmann, P. (2005). Simulation and patient safety: The use of simulation to enhance patient safety on a systems level. Current Anaesthesia \& Critical Care, 16(5), 273-281.

Stigen, A. (1979). Etikk. Oslo: Universitetsforlaget.

Søvig, K. H. (2019). Avgjørelser fra EMD i saker om vern av privat- og familieliv fra 2018. Tidsskrift for familierett, arverett og barnevernrettslige spørsmål (о3), 227-246. https://doi.org/10.18261/issn.0809-9553-2019-03-03 


\section{Vedlegg 1}

\section{Scenario 3: Gjennomføring av omsorgsovertakelse}

Tema: Forsvarlig tilbakehold/separasjon pá barsel etter $\$ 4.9$

Dato: 11-13.02.2019

Ansvarlige fagpersoner: $\mathrm{KS}, \mathrm{AS}, \mathrm{CB}$

Ansvar scenario: KS

Overordnet læringsmål:

Rettssikker og verdig gjennomføring av akutt separasjon like etter fødsel.

Trygge barnet

Læringsmål :

- God, tydelig og ivaretakende kommunikasjon, inkl. kroppsspråk, tilpasset en krisesituasjon

- Ivareta alle involvertes sikkerhet og særlig barnets

- Ivareta foreldrenes umiddelbare behov

- God tverrfaglig samhandling

\section{Hendelsesforløp:}

1.Samtale mellom foreldre, barselpersonale, evt. BUP sped og små, evt. annen støtteperson.

2. Sikring barnet slik barnevernet har besluttet.

3. Barnevernet formidler vedtak (får utdelt ferdig vedtak) og evt. videre planer.

4. Evt. kort ettersamtale.

Deltakere i scenarioet: Gravide Anne (17), Bjørn (25), barnet, jordmor, helsesøster, behandler KUB, evt. BUP sped og små, barnevern (Møteleder)

Observatører:

Beskrivelse av foreldre/barn: Anne (17) belastet oppvekst, bl.a. foreldre m. rusproblemer (sporadisk kontakt). Barneverntiltak siden 8-årsalder og fortsatt. Droppet ut av xg.skole. Før innleggelse KUB flere akutte innleggelser pga rus- og medikament-intox. I tillegg selvskading og spiseforstyrrelse. Gravid 2 mnd etter første møte $m$ Bjørn. Bjørn (25) gir et godt førsteinntrykk, trener mye, bor i leid hybelleilighet. Nylig flyttet til distriktet, men p.t. sykemeldt fra anleggsjobb. Idrettsskade i ungdommen førte til smerteproblem og avhengighet av smertestillende. Annet rusbruk ukjent. Ellers ukjente oppvekstforhold. Barnet født 2 uker før termin

Situasjon:. Anne skrev seg ut fra KUB/Reinsvoll og bodde siste mnd før fødsel sammen med Bjørn. BVT fikk bekymringsmelding om bekymring sfullt rusbruk i leiligheten. Barnet født rett etterpả, ca 2 uker før termin. Familien ligger ná på Forsterket/forlenget barsel. En dag virket Bjørn rusa mens han var på barsel, og ble hissig når han blir bedt om ă forlate. Anne virker trist og fjern, sover mye og er ustelt. Hun vegrer seg for ă stelle barnet og făr ikke til ă amme. Barnet har ikke tilfredsstillende vektoppgang og er vanskelig å roe. Foreldrene insisterer på ă reise hjem noen dager før planlagt. Barselpersonale har informert But om alvorlig bekymring og barnevernet iverksetter akutt tilbakehold

Tilleggsopplysninger:

Kun for markør/er: 



\title{
KAPITTEL 10
}

\section{Verdimøter som organisert læringsprosjekt}

\author{
Liv Randi Roland \\ Høgskolelektor, Høgskolen i Innlandet
}

\begin{abstract}
This chapter is based on the experiences from a mentoring program called Nattergalen (the Nightingale), in which social work, child care and community education students meet children with immigrant backgrounds. The students and children meet weekly to participate in activities for the mutual pleasure and learning of both parties. The activities are agreed upon in consultation with the children's parents. This chapter aims to provide a picture of the students' experiences with the children's home base. Through the many meetings with the children and their parents, together with the systematic reflection about these experiences, the students obtained a nuanced and varied understanding of the different value orientations in modern family life. The primary aim of Nattergalen is to add to and strengthen the students' multicultural skills and to motivate the children to attend school and to choose education. The chapter elucidates how the students who are participating in Nattergalen are being encouraged or coached to reflect on the varying value orientations in their meetings with children and their families.
\end{abstract}

Keywords: professional values, systematic reflection, multicultural skills, children and families with immigrant backgrounds

\section{Innledning}

Fremtidige barnevernsarbeidere skal gjennom sin profesjonsutdanning settes i stand til å møte ulike livsformer og verdiorienteringer i det norske mangfoldssamfunnet. «Barnevernet må forstå situasjonen familiene er i og kunne foreta vurderinger av barnets beste», heter det i siste høringsnotat 
om kompetanse i barnevernet (Barne- og familiedepartementet, 2020, s. 7). Vi vet at statistikken viser en svak overrepresentasjon av barn og unge med innvandrerbakgrunn under barneverntjenestens omsorg (Bufdir, 2020a). Det er en klar overrepresentasjon av denne gruppen hva gjelder hjelpetiltak i hjemmet (Bufdir, 202ob). Tiltakene begrunnes ofte ut fra kulturforskjeller (Aarset \& Bredal, 2018). I mange sammenhenger blir norske individorienterte levesett satt opp mot minoritetsfamiliers kollektivt orienterte, hvor barn og unge ofte beskrives som å pendle mellom to verdener - hjemmesfæren på den ene siden og skole og fritid på den andre. Familier med minoritetsbakgrunn har ofte familietradisjoner og måter å leve på som representerer andre verdier og forståelser av foreldreskap enn norske majoritetsverdier. Kollektive praksiser og verdier kan stå i motsetning til norske individuelle majoritetsverdier, som å fremme barns selvstendighet og frihet, noe som er høyt rangerte oppdragelses- og omsorgsverdier i majoritetsbefolkningen (se også kapittel 4 av Rysst).

De fleste studenter innen profesjonsfagene som kvalifiserer seg for å arbeide i barnevernet, er unge mennesker med norsk majoritetsbakgrunn. Utdanningsinstitusjonene skal utdanne kompetente yrkesutøvere som er i stand til å forstå og handle i situasjoner hvor viktige verdier står på spill. Det er på denne bakgrunnen avgjørende at de utvikler relevant kunnskap for studentene som skal møte flerkulturelle problemstillinger.

Dette kapitlet diskuterer hvordan mentorordningen Nattergalen kan være med på å forberede studentene på slike virkeligheter. Mentorordningen foregår som møter mellom bachelorstudenter fra helse- og sosialarbeiderutdanningene (barnevern, sosialt arbeid og vernepleie) og barn i alderen 8-12 år med minoritetsbakgrunn. I ti måneder skal studentene, sammen med barna, finne felles fritidsaktiviteter én dag i uken - både alene med sitt mentorbarn og sammen med andre mentorer og deres mentorbarn. Barnas ønsker og interesser skal være utgangspunktet for aktivitetene. Gjennom tiden studentene tilbringer sammen med barna, møter de barnas foreldre når de skal samarbeide om de ukentlige aktivitetene. Kapitlet fokuserer spesielt på hvordan studenter som deltar i Nattergalen, gis trening i å reflektere over ulike verdiorienteringer i møte med barna og deres familier. Den overordnede problemstillingen i 
kapitlet er: Hvilke verdier oppdager studentene i møte med barna og deres familier?

Som koordinator for ordningen ved Høgskolen i Innlandet (studiested Lillehammer) har jeg det faglige ansvaret for studentenes læring, og jeg koordinerer arbeidet gjennom å samarbeide med kontaktpersonene ved barnas skoler om rekruttering og informasjon til de aktuelle familiene. I det videre gis en kort beskrivelse av ordningen Nattergalen, mentorskap som læringsprosjekt og en teoretisk ramme om profesjonell verdilæring i en flerkulturell kontekst. Så følger en gjennomgang og diskusjon av datagrunnlaget som bygger på studentenes erfaringer i møte med barna og deres familier, med en kort avslutning til sist.

\section{Bakgrunn og perspektiv}

Overordnet kan man si at Nattergalen som ordning intenderer å fremme sentrale samfunnsverdier som sosial inkludering og deltakelse. Tiltaket kom i stand i 2008 som en oppfølging av Soria Moria-erklæringens satsing på et kultursensitivt barnevern.

Nattergalen har to målsettinger. Ordningen er både et inkluderingstiltak overfor barn med minoritetsbakgrunn og et læringsprosjekt for kommende profesjonsutøvere. Som inkluderingstiltak skal ordningen bidra til at barn og unge med minoritetsbakgrunn får bedre ferdigheter i norsk, $ø$ kt skolemotivasjon, styrket selvfølelse og flere mestringsopplevelser samtidig som de skal stimuleres til å ta videregående opplæring og høyere utdanning. Som læringsprosjekt skal det flerkulturelle i barnevernet styrkes gjennom at studenter får bedre kunnskap om og kompetanse knyttet til barn og unge med minoritetsbakgrunn og deres familie (Bufdir, 2014).

Ordningen er finansiert av Barne-, ungdoms- og familiedirektoratet (Bufdir) og finnes i dag ved åtte høgskoler og universiteter. Det er utarbeidet en egen manual som gir retningslinjer for mentorarbeidet. Fra 2008 til 2017 har 1238 barn deltatt i programmet (Jessen, Gundersen \& Hynek, 2018). Modellen er inspirert av det svenske prosjektet Näktergalen ${ }^{1}$, som

1 Navnet «Näktergalen» har delvis sin bakgrunn i Malmö-poeten Hjalmar Gullbergs diktning om nattergalen, og delvis i den symbolikken som ligger bak denne fuglen. Nattergalen er en fugl som synger vakkert når den kjenner seg trygg (hentet fra manualen [Bufdir, 2014] s. 3). 
har eksistert siden 1996 (Grander \& Lőnroth, 2011; Lagergren, 2020; Lőnroth 2007). Her er arbeidet finansiert av universitetene og deres samarbeidende kommuner, og studentene er primært rekruttert fra lærerutdanningene. I Norge er ordningen hovedsakelig knyttet til helseog sosialarbeiderutdanningene, med hovedvekt på barnevern. Over tid har flere utdanninger arbeidet for å få mentorskap integrert i studienes praksisutdanning i første studieår, mens andre opprettholder ordningen som et frivillig emne på fem eller ti studiepoeng som supplement til det ordinære studieforløpet.

Mentoren gis mulighet til å få innblikk i et barns liv, utvikle en relasjon til barnet over tid og være en rollemodell og et forbilde. Barnet gis mulighet til å få erfaringer og kunnskaper om mentorens hverdag som student, få en voksen tillitsperson utenfor familien og utvikle selvtillit gjennom felles aktiviteter. Barn og mentorer skal få økt respekt, forståelse og toleranse for hverandres ulike sosiale og kulturelle bakgrunn (Bakketeig, Backe-Hansen, Seeberg, Solberg \& Patras, 2011; Bufdir, 2014; Jessen et al., 2018; Lagergren, 2020; Lönroth, 2007).

I utvelgelsen av barna vektlegges ulike hensyn som kort botid i Norge, lite sosialt nettverk, lav deltakelse i organiserte fritidsaktiviteter eller generelle utfordringer med deltakelse og sosial kompetanse. Tilbud gis ikke til barn som lever i familier med omfattende sosiale problemer eller som mottar hjelpetiltak fra barnevernet (Bufdir, 2014).

\section{Mentorskap som grunnlag for læring og kunnskapsutvikling}

Som arbeidsform har mentorskap tradisjoner tilbake til antikken ${ }^{2}$ og er ofte forbundet med at en erfaren mester bruker sin kunnskap til å veilede en mer uerfaren svenn innenfor et arbeidsfelt. Til grunn for mentorskaptanken ligger et optimistisk menneskesyn og troen på personlig vekst med dialogen som en sentral dimensjon i arbeidet (Arnesson \& Albinsson, 2017; Lauvås \& Handal, 2015; Mathisen, 2015).

2 «Mentor» etter gresk, rådgiver for sønnen til Odyssevs, som ifølge et gresk sagn var konge på Ithaka. 
I ordningen er det flere mentorrelasjoner - mellom student og barn samt mellom fagansvarlig og studentene. I dialog med studentene veileder jeg som fagansvarlig studentene i deres personlige kunnskapsutvikling ved å lytte til, guide og stille spørsmål til deres erfaringer fra mentorarbeidet. Gjennom erfaringer som venn og rollemodell overfor mentorbarna utvikler studentene kunnskap for fremtidig yrkesutøvelse. Ørmen og Simensen (2016, s. 12) peker her på at det kan være en utfordring å bidra til at studentene orienterer seg mot en profesjonell relasjon gjennom refleksjon samtidig som de fremstår som forbilde og rollemodell i møte med barnet.

Som læringsprosjekt er mentorskapet en demokratisk prosess hvor tanker, refleksjoner og kunnskap utdypes. Vekslingen mellom ukentlige erfaringer, loggskriving og månedsrapporter, refleksjoner og dialoger i veiledningstimer skaper læring og utvikling. Mot slutten av mentortiden leser studentene fagtekster som gir dem mulighet for å begrepsfeste sine erfaringer i lys av teori. Tiden og de hyppige møtene «åpner for en tettere og annen form for kunnskapstilegnelse og personlig utvikling enn studentene får gjennom den ordinære praksisen» (Tveraabak, 2016, s. 113). Som profesjonskvalifisering for fremtidige yrkesutøvere er mentorordningen både et lærings- og et fagutviklingsprosjekt som bygger bro mellom ulike læringsarenaer og kunnskapsformer - teori og praksis, utdanning og yrkesfelt (Ask, 2016; Grander \& Lőnroth, 2011; Kunnskapsdepartementet, 2012; Tveraabak, 2016; Ørmen \& Simensen, 2016).

\section{Tidligere undersøkelser}

Ordningen er evaluert to ganger, henholdsvis i 2011 og 2018 (Bakketeig et al., 2011; Jessen et al., 2018). Mentorer, koordinatorer, skolenes kontaktpersoner og barna er intervjuet, noen få foreldre er intervjuet i 2011. Begge undersøkelsene indikerer at mentorskapet i all hovedsak fungerer etter intensjonen. Barn og mentorer opplever møtene som lærerike, og studentene anser mentorskapet som svært nyttig for fremtidig yrkesutøvelse. Selv om ordningen i liten grad legger opp til utstrakt kontakt med mentorbarnas familie, vektlegges foreldrene som viktige støttespillere i arbeidet. Barneskoleansatte og koordinatorer har erfaringer med at 
foreldre har vært skeptiske til å delta i ordningen, og at det blant annet ut fra språkbarrierer tar tid å bygge et samarbeid som skal sikre foreldrene «nødvendig deltakelse og informasjon» (Jessen et al., 2018, s. 84). Evalueringen av 2018 konkluderer med at samarbeidet med foreldrene har bedret seg over tid, og at ordningen stort sett har et positivt rykte på skolene som deltar. Foreldres skepsis har ofte vært forbundet med at studentene kommer fra barnevernutdanningen, og løsningen har i noen tilfeller vært å underkommunisere at det er snakk om barnevernstudenter (Jessen et al., 2018, s. 106). Om den løpende kontakten mellom foreldre og mentor heter det: «Hovedinntrykket er at mentorene i stor grad blir delegert ansvaret for barna den tiden de er sammen, og at mentorene unntaksvis er sammen med familien og kun møter dem ved henting og levering» (Jessen et al., 2018, s. 86). Evalueringen stiller spørsmål ved om studentenes læringsutbytte med tanke på flerkulturell kunnskap vil $ø$ ke om man legger opp til et nærmere samarbeid med barnas familie (Jessen et al., 2018, s. 86). Evalueringene oppsummerer med at studentene ønsker mer samarbeid med foreldrene. Her understrekes det at mer tid til mer samarbeid i så fall vil gi mindre tid til hovedaktiviteten, som er møtet mellom mentor og barn. De relativt få intervjuene som ble foretatt med foreldrene om deres erfaringer med ordningen i 2011, viser at de ikke opplever det som et problem at det er begrenset involvering fra deres side (Bakketeig et al., 2011 s. 236).

Erfaringene fra foreldreintervjuer i det svenske Näktergalen viser at foreldrenes delaktighet anses som en nøkkelfaktor for å lykkes i mentorvirksomheten, da de ønsker å komme med innspill til de ukentlige treffene og være en støtte for mentoren (Lagergren, 2020; Lönroth, 2007). Amerikanske studier viser også at foreldre på ulike måter kan være sentrale premissleverandører i mentorvirksomheten og en sentral faktor for hvordan mentorordningen fungerer (Basualdo-Delmonico \& Spencer, 2016; DuBois, Holloway, Valentine \& Cooper, 2002; Keller et al., 2018).

Det er skrevet flere faglige bidrag fra den norske Nattergal-ordningen med utgangspunkt i studentenes læringserfaringer i samhandlingen med sine mentorbarn (Ask, 2016; Tveraabak, 2016; Ørmen \& Simonsen, 2016), og også fra koordinatorenes og barneskolenes perspektiv (Kraus, 2019; Marten, 2019). I dette kapitlet er fokuset spesielt rettet mot hvordan 
studentene reflekterer over sine møter med barnas familier og hjemmemiljø. Hvilke verdier oppdager de hos seg selv og hos «de andre»?

\section{Flerkulturelle verdimøter}

I samhandlingen med barna og deres familier får studentene mulighet til å utforske egne personlige verdipreferanser og utvikle en bevissthet om hva som oppfattes som godt eller viktig hos seg selv og «de andre» (se også Rysst kapittel 5 i denne boken). Rysst (2008) fremholder med referanse til blant annet Roy D'Andrade at verdier er knyttet til normer og tilegnes gjennom sosialisering i ulike sosiale kontekster gjennom hele livsløpet. Som barnevernsarbeider er man forpliktet tilå utforske det faktiske grunnlaget for hvilke verdipreferanser som ligger til grunn hos den andre, sier Nordby i sitt kapittel i denne boken (kapittel 4).

Gjennom utdanningen sosialiseres fremtidige helse- og sosialarbeidere til viktige profesjonsetiske verdier som skal ligge til grunn for det helse- og sosialfaglige arbeidet. I Yrkesetisk grunnlagsdokument (Fellesorganisasjonen [FO], 2019, s. 5) er verdiene konkretisert som «menneskeverd, respekt for den enkeltes integritet, anerkjennelse, ulikhet og ikke-diskriminering, helhetssyn på mennesker, tillit, åpenhet og redelighet, solidaritet og rettferdighet». Dette er generelle verdier som igjen bygger på demokratiske og humanistiske verdier som må identifiseres og konkretiseres i den spesifikke yrkeskonteksten for at det skal gi studentene innsikt og bevissthet rundt hva dette betyr i møte med ulike sårbare grupper. Bare på denne måten kan de utvikle et profesjonelt verdisett. Utdanningsinstitusjonene skal tilby undervisningsformer for etisk og kritisk refleksjon hvor studentene skal lære å utvise respekt overfor brukerens verdier og livsvalg. I tillegg skal de oppøve et kritisk blikk på grunnleggende samfunnsverdier som ligger til grunn for rammene for det sosialfaglige arbeidet (FO, 2019, s. 3). I denne sammenhengen er brukerne barn og familier med minoritetsbakgrunn. Spørsmålet blir her hvordan disse verdiene settes i spill i møte med mennesker med andre livserfaringer, annet språk og annen kulturbakgrunn enn den norske majoritetsbefolkningen.

Rugkåsa, Ylvisaker og Eide (2017) retter i boken Barnevern i et minoritetsperspektiv et kritisk blikk på kunnskapsgrunnlaget og yrkesutøvelsen 
i sosialfaglig flerkulturelt arbeid, og de argumenterer for et perspektiv hvor maktdimensjonen mellom minoritet og majoritet i større grad trekkes inn. Når mer eller mindre tradisjonelle norske normer og verdier ligger til grunn for forståelse av foreldreskap og omsorg, slik også Rysst (kapittel 5) skriver om, kreves det at sosialarbeideren som representant for majoriteten hever blikket ut over norske måter å forstå verden på (Rugkåsa, 2008; Rugkåsa et al., 2017). Denne måten å tenke på er uttrykk for et kulturanalytisk blikk som har fokus på både minoritet og majoritet og ikke minst på majoritetens maktposisjon - sosialarbeiderens makt. Reflekterer vi ikke over vår egen majoritetsposisjon som sosialarbeidere, kan vi komme til å skade mange.

Gullestad (2002) problematiserer underliggende tenkemåter og praksiser $\mathrm{i}$ «det norske» og mener at egne selvfølgeligheter må bli mindre selvfølgelige. Hun er opptatt av å overskride kategoriene «oss» og «dem» og gjøre identiteten som norsk så rommelig at den inkluderer både lik og forskjellig. Hun peker videre på at i dag betyr flerkultur mer eller mindre det samme som noe «de andre» har, selv om kultur i høy grad også definerer «oss selv». Det er en utbredt forventning at familier med minoritetsbakgrunn skal tilpasse seg det norske samfunnet, norske institusjoner og norske verdier. For barna sin del skal de lære å manøvrere i den norske skolehverdagen med skolens krav og forventning til viktige verdier om selvstendighet og ansvar for egen læring. Det er forventet at de skal delta på ulike fritidsarenaer, kort sagt tilpasse seg den norske barndommens oppvekstverdier. I det sosiale samværet med jevnaldrende skal de forstå og mestre uttalte og uuttalte koder. Lidén (2017, s. 200) hevder at måten barna mestrer denne hverdagen på, også avhenger av hvor stort sprik eller samsvar det er mellom oppdragelsen hjemme og skolens forventninger, og at barna kan mangle voksenpersoner som kan hjelpe med den «oversettelsen» de kan ha bruk for. Det er denne virkeligheten mentorene får mulighet til å komme tett på gjennom de mange møtene med barna og deres familie. Å oppøve et våkent blikk for barnas hjemmebase at studentene er positivt nysgjerrige på familiens verdipreferanser og utfordringer i livet i Norge - er sentralt for å kunne bistå barna i dette oversettelsesarbeidet. 


\section{Metode og datagrunnlag}

Som koordinator og fagansvarlig for Nattergalen har jeg siden $2016 \mathrm{fulgt}$ 60 studenter, 50 kvinner og 10 menn, hvor cirka en tredel av studentene kommer fra familier med minoritetsbakgrunn. Studentene er typisk unge mennesker i begynnelsen av tjueårene og er rekruttert fra studieretningene barnevern, sosionom og vernepleie. I søknaden om å bli mentor oppga flere at de hadde lite kjennskap til barn, og flere ga uttrykk for at de hadde lite erfaring med «barn og familier fra andre kulturer». De fleste oppga også at de ønsket å bli mentor for å få en praksis som kunne gjøre dem mer trygge på seg selv i en fremtidig yrkesrolle. Studentgruppens sammensetning og motivasjoner for å bli mentor samsvarer med det vi har sett fra andre læresteder med tilsvarende ordninger (jf. Ask, 2016; Bakketeig et al., 2011; Lagergren, 2020; Tveraabak, 2016).

I tillegg til den faglige oppfølgingen av studentene fordrer koordinatorrollen et løpende samarbeid med barneskolenes kontaktpersoner, barn og foreldre. Jeg har hatt samtaler med foreldrene ved oppstart og avslutning for å informere om Nattergalens hensikt. Gjennom denne kontakten til foreldrene er jeg i løpet av arbeidet blitt opptatt av barnas hjemmebase og foreldrenes rolle i mentorarbeidet. Jeg bygger her på disse erfaringene, men mine data er i hovedsak studentenes skriftlige materiale i form av søknaden om å bli mentor, deres månedlige rapporter fra de ukentlige aktivitetene sammen med barna samt deres sluttevaluering. Jeg har innhentet samtykke fra studentene til å bruke dette materialet $i$ anonymisert form.

Mitt utvalg av studentenes tekster og mine fortolkninger er farget av min erfaring som underviser for bachelorstudenter og mine mange år med praktisk sosialt arbeid i migrasjonsfeltet. Sånn sett er jeg forsker i eget felt med de fordeler og fallgruver det innebærer (Repstad, 2007). Dette betyr at jeg kjenner godt både problemstillingene og diskusjonene som har preget dette feltet de siste tiårene. Samtidig har dette selvfølgelig også bidratt til at jeg har min egen forforståelse som fargelegger min oppmerksomhet på hvilke problemer og utfordringer studentene vil møte i mentorrollen - noe som i sin tur også kan bidra til at jeg legger overdreven vekt på de observasjonene som stemmer best overens med mine forventninger til hvilke erfaringer studentene ville erverve seg. Som koordinator har jeg hatt samtaler og møter som jeg har loggført 
fortløpende, og disse utgjør også bakgrunnen for mine fortolkninger av data.

Studentenes tekster utgjør et rikt materiale. I denne sammenhengen har jeg ut fra studentenes skriftlige materiale sett etter utsagn og hendelser som handler om deres erfaringer med barnas hjemmebase. De utvalgte temaene har jeg igjen fortolket i lys av noen verdidimensjoner. Studentene bruker sjeldent verdibegrepet eksplisitt, men de forteller om hendelser som har overrasket dem, og som de har kommet til å tenke på. Jeg har lett etter formuleringer som «det ble jeg forbauset over», «det har jeg ikke tenkt over», «her kjente jeg meg igjen», «denne hendelsen gjorde at jeg plutselig forsto». I disse formuleringene uttrykker studentene ofte noen verdier om hva som er bra og viktig. De utvikler en bevissthet om ulike verdipreferanser som kan inngå i et reflektert profesjonelt verdisett. Dette kommer på ulike måter til uttrykk i materialet som har dannet grunnlag for drøftingen nedenfor.

\section{Møter med nye virkeligheter og nye verdier}

Det første møtet med familiene var for alle mentorene preget av en følelse av usikkerhet og spenning overfor noe nytt og ukjent. Ved oppstart møtte studentene barna og deres familier enten på en fellessamling, hjemme hos familiene eller et sted utenfor hjemmet. De beskrev første møte slik: «Med hjertet i halsen», «jeg vil ikke kalle det ubehagelig, men kanskje litt pinlig, for alle var litt usikre på hverandre», «det var som å komme inn i en annen verden». En student fortalte hvordan hun følte seg som en «inntrenger på ukjent territorium». En annen fortalte at hun ble veldig fokusert på seg selv og sine forestillinger om en «normal» familie:

Man tenker ikke at man skal besøke en familie med to foreldre som har barn, hus, arbeid og et ellers «normalt» liv. Men man vet at man skal møte en familie med minoritetsbakgrunn, og det blir denne bakgrunnen som limer seg fast til hjernen.

Studenten utdypet ikke videre hva det er som limer seg fast, men viste her en forforståelse om at denne familien var annerledes enn hennes forestilling om en tradisjonell norsk kjernefamilie med mor og far og barn - som 
jo nettopp er «forestillingen om», dagens Norge som utviser en bred vifte av ulike familieformer med ulike verdipreferanser for det gode liv.

Studentene fortalte samtidig om deres forbauselse og glede over foreldrenes varme velkomst og positive holdning overfor dem som mentorer. En uttrykte seg slik: «Jeg følte veldig ærefrykt, jeg ble gitt stor tillit fra foreldrene - de overlot deres dyrebareste skatt i mine hender.» Studentene ble her møtt med tillit og åpenhet fra foreldrene - verdier som de selv skal oppøve som profesjonelle yrkesutøvere.

\section{De ukentlige aktivitetene}

Aktivitetene ble avtalt med foreldrene, via tekstmelding eller telefon. I noen tilfeller hentet og brakte mentoren barnet hjemme hos foreldrene, i andre tilfeller leverte og hentet foreldrene barna på et avtalt sted, for eksempel på biblioteket. Når studentene beskrev samarbeidet og kommunikasjonen med foreldrene om de ukentlige aktivitetene sammen med barna, hadde de ulike erfaringer.

Flere fortalte om vansker i kommunikasjonen, spesielt i starten, som ofte var forbundet med språkbarriere: «Det tok veldig lang tid før jeg fikk svar», «det er vanskelig å forstå innholdet i meldingene», «jeg måtte bruke barnet som tolk når jeg ringte», «jeg tok flere bomturer til familien fordi de ikke hadde svart, eller jeg forsto ikke meldingen». Mentorene fortalte hvordan de i samtaler - både med barn og foreldre - tok i bruk nye sider ved seg selv og fant kreative løsninger som Google Translate, bilder og videoer og til tider et slags tegnspråk, og de fikk øvelse i å uttrykke seg klart i korte setninger. En student som strevde med kommunikasjonen med familien, uttrykte seg slik:

Selv om jeg hadde problemer med å lage avtaler med familien, var de alltid veldig gjestfrie ved å be meg inn hver gang. Dermed fikk jeg snakket mye med dem - og det var en helt annen virkelighet enn det jeg er vant til.

Studentenes tekster viste at det for noen var utfordrende å holde kontakten med familien. Flere viste til hendelser som kunne ha utviklet seg til konflikter og misforståelser. Det kunne for eksempel ta lang tid før foreldrene svarte, og svarene var ikke alltid lette å tolke for mentorene. Den 
usikkerheten disse erfaringene førte med seg ble imidlertid «dempet» og bearbeidet gjennom flere møter med familiene, og gjennom erfaringsutveksling med de andre mentorene og meg som veileder. Mot slutten av mentoråret fortalte en student om hvordan hun oppdaget at det hun $\mathrm{i}$ starten opplevde som store kommunikasjonsproblemer, etter hvert viste seg å være «tynne forskjeller og små misforståelser». Studentene erfarte her at «å bygge en relasjon» helt konkret - sten på sten - tar tid. De ble oppmerksomme på at relasjoner handlet om gjensidighet - at de også måtte gi noe av seg selv.

\section{Mentoren som link til det norske}

Studentene fortalte om flere hendelser hvor de fikk et blikk på noen verdier som ligger til grunn for barnas situasjon på skolen og den fritidsarenaen barna skal inkluderes i. En mentor fortalte hvordan hun ville hjelpe sitt mentorbarn som ønsket å begynne med håndball, og mentoren gikk entusiastisk inn for å hjelpe. Hun sier: «For eksempel tok jeg det for gitt at foreldre til mentorbarnet mitt visste hva håndball var, og hvor viktig dette er. Men foreldrene til mentorbarnet hadde ikke denne forståelsen for fritidsaktiviteter.» Dessuten oppdaget hun at mange av fritidsaktivitetene kostet penger, noe som var vanskelig for foreldre med knapp økonomi. ${ }^{3}$ Her fikk mentoren et blikk på betydningen og verdien av den norske velorganiserte fritidssfære hvor det er en rekke uttalte og ikke uttalte forventinger om foreldres økonomiske og emosjonelle deltakelse på vegne av sine barn. I oppsummeringen på slutten av mentoråret berettet en student hvordan han hadde fått ny innsikt i den norske skolen sett fra mentorbarna og foreldrenes perspektiv. Mentoren sa dette slik: «Jeg har sett at familien balanserer mellom norske og hjemlandets verdier, og hvordan foreldrenes deltakelse har sammenheng med barnas mulighet for integrering.» En annen mentor sa dette om det norske skolesystemet: «Jeg forsto at det var mange ting mitt mentorbarn ikke forsto. Han kan ikke norske referanser - han kan ikke Anne Cath. Vestly sanger. Jeg har

3 Familiene skal selv dekke de økonomiske utgiftene til barnas aktiviteter, mens studentene får sine utgifter dekket gjennom ordningen. 
sett at den norske skolen belønner enkelte type verdier.» Studentene får her et innblikk i verdier i det norske samfunnet som de har tatt for gitt, sider som kan fremstå som fremmede institusjoner og ordninger for foreldregenerasjonen i minoritetsfamiliene. De fleste studentene rapporterte samtidig om foreldre som var opptatt av barnas videre skolegang, og som her så verdien i mentorens bidrag som hjelper. En mentor refererte her til sitt mentorbarn som uttalte: «Mamma vil at vi skal gjøre det bra på skolen, fordi hun ikke hadde muligheten selv.» Og flere refererte til foreldre som uttrykte at de selv hadde ønsket seg en mentor da de kom til Norge. Mentorenes erfaringer her harmonerer med Nattergalens målsetting om å stimulere barn og unge til utdanning, som jo er en grunnleggende norsk samfunnsverdi.

\section{Innsikt i ulike familieliv og verdier}

Det er stor variasjon i mentorenes erfaringer med ulike familiepraksiser, og i hvor mye kontakt mentorene hadde med barnas familie. Noen kom tett på og ble invitert inn til familiene ukentlig til mat og drikke. Dette var ofte i familier med kort botid i Norge. Her fortalte mentorene om at de fikk innsyn i familienes liv. De ble vist bilder og videoer fra hjembyen, huset, og barnas skole. Noen familier fortalte fra oppbrudd i krig og flukt, fra krig og fra opphold i eksil og om bekymring for familiemedlemmer som har det vanskelig på grunn av krig og flukt. En av studentene beskrev sine erfaringer slik:

Jeg ble invitert inn mange ganger til familien, ingen kunne noe norsk, spesielt i starten kjente jeg på den kleine stemninga. Det var veldig ubehagelig å bli satt på sidelinja og kjenne på ubehaget, å være i rollen som den som ikke forstår, når familien snakker seg imellom.

De fleste mentorene fortalte om hendelser hvor de kunne identifisere seg med familienes minoritetsposisjon. Flere reflekterte over denne posisjonen som en nødvendig erfaring på veien mot å utvikle et profesjonelt verdisett hvor det å ta den andres perspektiv er en sentral verdi. Andre mentorer som ikke var hjemme hos familien til sitt mentorbarn, fortalte at de hadde ønsket dette. Samtidig rapporterte de samme studentene at 
dette også hadde gitt dem viktige erfaringer som fremtidig helse- og sosialarbeidere om verdiene respekt og personlig integritet. En av mentorene uttrykte dette slik: «Det er ikke alle som vil slippe hvem som helst nær innpå familien sin. Det er noe jeg må respektere». På slutten av mentoråret oppsummerer en annen mentor:

Jeg ble aldri invitert inn til familien. Det kan være tilfeldig. For da jeg skulle velge ut artikler til eksamen, kjente jeg meg ikke igjen i de artiklene jeg hadde fått på pensum - fordi jeg kjente ikke igjen min familie i pensumtekstene - de kunne vært en helt alminnelig norsk familie - det var ikke så mye kulturforskjeller som jeg trodde.

En student som ofte ble invitert inn til familiene ved henting og levering beskrev sine erfaringer slik: "Jeg var forbauset over hvor kollektive de var - når jeg skulle snakke med foreldrene, var hele familien der.» $\mathrm{Og}$ andre fortalte om sitt mentorbarn som lever i to forskjellige verdener, ute og hjemme:

Det er et gap mellom livet mitt mentorbarn har hjemme sammen med familien, og det hun har sammen med venner og på skolen. Hun inntar ulike roller og tilpasser seg konteksten. Hjemme snakkes det arabisk, det er arabisk mat på bordet, kulturen og islam ivaretas, og det ser ut til at hun tar seg av småsøsken, i større grad enn det som er «vanlig» for en norsk familie. Ute viser hun en fornorsket utgave av seg selv.

Andre igjen fortalte at de ikke erfarte så store forskjeller i familiepraksiser som de hadde forventet. Flere fortalte at deres mentorbarn var «ganske norske», eller at de etter hvert oppdaget at «de var ikke så muslimske». Dette er alle erfaringer som er uttrykk for forforståelser knyttet til ulike familieverdier.

Materialet viser at mentorene som selv hadde minoritetsbakgrunn, både kjente og ikke kjente seg igjen i familienes verdier. Slik beskrev en av dem sine refleksjoner:

Jeg, som selv har en annen kulturell bakgrunn, kunne tenke meg at det skulle være lettere for meg å forstå meg på familiens kulturelle koder og normer, men samtidig er jeg oppvokst i Norge og vil ha norske verdier og normer som er 
tilpasset samfunnets majoritet. Jeg blir oppmerksom på hvordan jeg fremstår som bærer av majoritetens verdier og normer i samfunnet.

Andre hadde andre erfaringer. En uttrykte sine opplevelser på denne måten: «Jeg følte selv at jeg kom litt hjem da jeg kom inn i min mentorfamilie.» Flere oppdaget det positive i å ha en annerledes bakgrunn enn majoriteten - de fikk et nytt blikk på seg selv og på mentorbarnet. - fikk fatt i verdien av å ha to type erfaringer.

Studentene fortalte at de oppdaget at familiene gjennom ulike sosiale medier hadde hyppig kontakt med nære familiemedlemmer spredt over hele verden. Mange la merke til at foreldrene ofte snakket sitt morsmål med barna, fordi det var viktig for barna å holde kontakten til besteforeldre og andre familiemedlemmer. Med andre ord oppdaget mentorene at verdier som transnasjonale familiebånd var viktig for familiene. Familiene var på ulike måter, og i varierende grad, opptatt av å opprettholde tradisjoner fra hjemlandet, og å opprettholde kontakten med familie og nettverk. At det for mange foreldre var verdifullt at barna skulle ha kunnskap om deres morsmål, kan forstås som en måte å overføre familienettverkets verdier på. Ingen av studentene stilte spørsmål ved familiens verdigrunnlag.

Som nevnt innledningsvis var mange av studentene i starten opptatt av å lære om «de andres kultur». I løpet av mentoråret erfarte mange at kultur ikke alltid var forklaringen på situasjoner som de ikke forsto. Og de ble oppmerksomme på andre utfordringer som familiene hadde, som var knyttet til leveår med familienes trangboddhet, begrensede økonomiske ressurser og ikke minst familienes strev med å forstå ulike ordninger ved det norske systemet.

Det er det siste året kommet to rapporter som omhandler det å være foreldre og minoritet, som bygger opp under studentenes erfaringer (Smette \& Rosten, 2019; Friberg \& Bjørnset, 2019). Studiene peker på at foreldrepraksis i minoritetsfamilier i større grad må ses i sammenheng med familiens levekår og livssituasjon og deres migrasjonsprosess. Smette og Rosten (2019, s. 117) peker på at det i den offentlige diskusjonen ofte er fokus på problematisk foreldrepraksis hvor foreldre står i veien for at barna kan ta selvstendige valg som bryter med kollektivistiske tradisjoner. Begge rapportene peker på behovet for varierte 
beskrivelser som nyanserer oppfatninger om foreldreskap og oppdragelse i minoritetsfamilier.

Foreldrene i Smettes og Rostens (2019) studie forteller at de opplever at deres familieverdier er under press, de er redde for at barna skal bli for norske, og de er redde for å miste foreldreautoriteten. Denne frykten er ikke noe som mentorene i Nattergalen rapporterte om. Ingen studenter rapporterte om at foreldre avviser den vestlige kulturen - tvert imot aksepterer de mye ved den, men de vil «balansere» den med egne verdier og knytte bånd til de verdier de kjenner fra før. Å oppøve et blikk for de balanseøvelsene foreldre fra sin minoritetsposisjon kan oppleve, er viktig flerkulturell kunnskap. Våre studenter rapporterte om foreldre som kunne ha krevende hverdager, hvor norske ordninger, koder og referanserammer ikke var like naturlig.

\section{Avslutning}

Det er store variasjoner i studentenes opplevelser. De kom alle i situasjoner som utfordret dem på ulike måter, alt fra verdier, kommunikasjon til praktiske problemer. Felles for dem var at de måtte bestrebe seg på å forstå, og de jobbet seg gjennom de utfordringene de møtte. De ble rystet ut av egne selvfølgelige tenkemåter, og de ble satt i situasjoner hvor de fikk kjenne på den andres perspektiv. Dette er i seg selv ingen garanti for at alle studentene greide å oppnå det de ønsket overfor sine mentorbarn, men det er ingen tvil om at de har akseptert utfordringen av egne verdier og har fått en større forstålse for andres perspektiver. Det at studentene tålte å stå i vanskelige og uforståelige situasjoner, at de tålte uroen og usikkerheten, førte til at de på slutten av mentoråret følte en trygghet til å møte brukere uavhengig av yrkeskontekst. Slik sett er kunnskapen overførbar.

På hvilke måter samarbeidet med foreldrene i Nattergalen og lignende ordninger kan og skal styrkes, gir dette kapitlet ikke uttømmende svar på. Mye tyder på at når mentorskapet fungerer godt, er mentoren til god hjelp for foreldrene i en ellers ganske krevende hverdag. For å få ytterligere kunnskap om dette må man snakke mer systematisk med foreldrene. 
Mentorordningen sosialiserer til viktige profesjonsetiske verdier. Studentene utvikler et profesjonelt verdisett gjennom mentorperioden og systematiske refleksjoner over møtene med barna og familien. I våre profesjonsutdanninger er det i liten grad tilrettelagt for kunnskapsutvikling gjennom langsomme refleksive prosesser. Læringsprosjektet har vist at det tar tid å få øye på egne og andres verdier. På en konkret og virkelighetsnær måte har studentene fått forståelse for noen sentrale verdier i det moderne flerkulturelle samfunnet.

\section{Litteratur}

Aarset, M. F. \& Bredal, A. (2018). Omsorgsovertakelser og etniske minoriteter. En gjennomgang av saker i fylkesnemda. (NOVA Rapport 5/2018). Hentet fra http://flyktning.helsekompetanse.no/sites/flyktning.helsekompetanse.no/files/ Omsorgsovertakelser_og_etniske_minoriteter_En_gjennomgang_av_saker_i_ fylk.PDF

Arnesson, K. \& Albinsson, G. (2017). Mentorship - a pedagogical method for integration of theory and practice in higher education. Nordic Journal of Studies in Educational Policy, (3), 202-217.

Ask, T. A. (2016). Hva synger Nattergalen om? Samskaping av flerkulturell kompetanse mellom studenter og barn i mentorordningen Nattergalen. I S. B. Eide \& I. Trysnes (Red.), Sosionomutdanning på Sørlandet. Festskrift ved 25-årsjubileet høsten 2016 (s. 83-102). Kristiansand: Portal Forlag.

Bakketeig, E., Backe-Hansen, E., Seeberg, M. L., Solberg, A. \& Patras, J. (2011). Gjensidig trivsel, glede og loering. Evaluering av mentorordningen «Nattergalen» (NOVA Rapport 26/2011). Hentet fra http://www.nova.no/asset/5062/1/5062_1.pdf Barne- og familiedepartementet (2020). Høringsnotat - Kompetanse i barnevernet. Hentet fra https://www.regjeringen.no/contentassets/702b63a92c5243 eea4cd68c95b3dob5a/horingsnotat-om-kompetanse-i-barnevernet1.pdf

Basualdo-Delmonico, A. M. \& Spencer, R. (2016). A parent's place: Parents' and program staff members' expectations for and experiences of parental involvement in community-based youth mentoring relationships. Children \& Youth Services Review, 61, 6-14.

Bufdir. (2014) Manual for Nattergalen. Hentet fra file://C:/Users/700191/Desktop/ kapittelet/Manual\%2ofor\%2oNattergalen\%2orev\%202014\%2opdf.pdf

Bufdir. (2020a, 1 april). Barnevernsstatistikk. Hentet 19.november 2019 fra https:// www.bufdir.no/Statistikk_og_analyse/Barnvern/ 
Bufdir. (202ob, 2 mars). Barnevernstiltak til barn og unge med innvandrerbakgrunn. Hentet fra https://bufdir.no/Statistikk_og_analyse/Barnevern/Barnevernstiltak_ blant_barn_med_ulik_landbakgrunn/

Friberg, J. H. \& Bjørnset, M. (2019). Migrasjon, foreldreskap og sosial kontroll. (Fafo Rapport 1/2019). Hentet fra https://www.fafo.no/images/pub/2019/20698.pdf

Fylkesnes, M. K., Iversen, A. C., Bjørknes, R. \& Nygren, L. (2015). Frykten for barnevernet: En undersøkelse av etniske minoritetsforeldres oppfatninger. Tidsskriftet Norges Barnevern, 92(2), 80-96.

DuBois, D. L., Holloway, B. E., Valentine, J. C. \& Cooper, H. (2002). Effectiveness of mentoring programs for youth: A meta-analytic review. American Journal of Community Psychology, 30(2), 157-197.

Fellesorganisasjonen (FO). (2019). Yrkesetisk grunnlagsdokument 2019-2023. Tilgjengelig fra https://www.fo.no/yrkesetikk/fo-yrkesetisk-grunnlagsdokument2019-2023-article6951-1346.html

Grander, M. \& C. S. Lönroth. (2011) Mentorskap for barn och unga. Malmö: Malmö högskola, Lärande och Samhälle.

Gullestad, M. (2002). Det norske sett med nye øyne. Oslo: Universitetsforlaget.

Handal, G. \& Lauvås, P. (2015). Veiledning og praktisk yrkesteori. Oslo: Cappelen Akademiske Forlag.

Jessen, T. J., Gundersen, T. \& Hynek, K. A. (2018). Evaluering av Nattergalen - en oppfølgingsstudie (NOVA Rapport 2/2018). Hentet fra http://www.hioa.no/OmOsloMet/Senter-for-velferds-og-arbeidslivsforskning/NOVA/Publikasjonar/ Rapporter/2018/Evaluering-av-Nattergalen

Keller, T. E., Overton, B., Pryce, J. M., Barry, J. E., Sutherland, A. \& DuBois, D. L. (2018). "I really wanted her to have a big sister": Caregiver perspectives on mentoring for early adolescent girls. Children \& Youth Services Review, 88, 308-315.

Kraus, I. L. (2019). Barneskolens arbeid med mentorprogrammet Nattergalen. (Mastergradsavhandling). Universitetet i Agder, Kristiansand.

Kunnskapsdepartementet. (2012). Utdanning for velferd. (Meld. St. 13 (2011-2012)). Hentet fra https://www.regjeringen.no/no/dokumenter/meld-st-13-20112012/ id672836/

Lagergren, L. (2020). Näktergalens mentorsverksamhet - möten for vaxande (Rapport). Universitetet i Malmö, Malmö. Hentet fra https:// nightingalementoring.mau.se/2020/04/o8/new-research-and-evaluation-frommalmo-university-by-lars-lagergren

Lidén, H. (2017). Barn og migrasjon. Mobilitet og tilhørighet. Oslo: Universitetsforlaget. Lönroth, C. S. (2007). Näktergalen - En knuff framåt (Rapport om utbildning, 2). Hentet fra http://muep.mau.se/bitstream/handle/2043/6045/N\%c3\%a4ktergalen\%2O-\%2O En\%2oknuff\%2ofram\%c3\%a5t\%2023\%20aug\%202007.pdf? sequence=1\&isAllowed=y 
Marten, H. (2019). The use of mentoring as an integration tool - a case study of the Nightingale mentoring programme in Trondheim, Norway (Mastergradsavhandling). Norges teknisk-naturvitenskapelige universitet, Trondheim.

Mathisen, P. (2015). Mentor. Mentoring i teori og praksis (2. utg.). Bergen: Fagbokforlaget.

Regjeringen Stoltenberg. (2005). Plattform for regjeringssamarbeidet mellom Arbeiderpartiet, Sosialistisk Venstreparti og Senterpartiet 2005-09. Hentet fra https://www.regjeringen.no/globalassets/upload/smk/vedlegg/2005/ regjeringsplatform_soriamoria.pdf

Repstad, P. (2007). Mellom noerhet og distanse. Kvalitative metoder i samfunnsfag. Oslo: Universitetsforlaget.

Rugkåsa, M., Ylvisaker, S. \& Eide, K. (2017). Barnevern i et minoritetsperspektiv. Oslo: Gyldendal Akademisk.

Rugkåsa, M. (2008). Majoriteten som premissleverandør. I A. M. Otterstad (Red.), Profesjonsutøvelse og kulturelt mangfold: fra utsikt til innsikt (s. 78-95). Oslo: Universitetsforlaget.

Rysst, M. (2008). I want to be me. I want to be kul. (Doktoravhandling). Universitetet i Oslo, Oslo.

Smette, I. \& Rosten, M. G. (2019). Et iakttatt foreldreskap. Om å vare foreldre og minoritet $i$ Norge (NOVA Rapport 3/2019). Hentet fra https://fagarkivet.oslomet. no/nb/item/asset/dspace:13263/NOVA-Rapport-3-2019-Et-iakttatt-foreldreskap. pdf

Tveraabak, M. (2016). Nattergalen - møter med muligheter. I R. Follesø, C. T. Halås \& C. H. Anvik (Red.), Sett, hørt og forstått? Om profesjonelle møter med unge i sårbare livssituasjoner (s. 112-127). Oslo: Universitetsforlaget.

Ørmen, N. \& Simensen, H. (2016). Kompetanseutvikling gjennom mentorskap. Tidsskriftet Norges Barnevern, 93(03-04), 264-277. https://doi.org/10.18261/ issn.1891-1838-2016-03-04-10 



\section{Forfatterbiografier}

Camilla Bennin er høgskolelektor ved Institutt for sosialvitenskap og veiledning ved Høgskolen i Innlandet. Hun er jurist og underviser på bachelor i barnevern og master i tverrfaglig arbeid med barn og unge. Bennins forskningsinteresse er i hovedsak barnevernrett. E-post: camilla. bennin@inn.no

Astrid Halsa er førsteamanuensis ved Institutt for sosialvitenskap og veiledning ved Høgskolen i Innlandet. Hun har doktorgrad i sosiologi og er studieprogramansvarlig for master i tverrfaglig arbeid med barn og unge. Hun er også prosjektleder for Norges forskningsråds prosjektet «Decisions and justifications in child protection services». Halsas forskningsinteresser er utsatte barn, unge og deres familier. E-post: astrid.halsa @inn.no

Grethe Netland er instituttleder og førsteamanuensis ved Institutt for sosialvitenskap og veiledning ved Høgskolen i Innlandet. Hun har en doktorgrad i filosofi fra Institutt for filosofi, idé- og kunsthistorie og klassiske språk ved Universitetet i Oslo. Netlands forskningsinteresser er i første rekke politisk filosofi og profesjonsetikk. E-post: grethe.netland@ inn.no

Halvor Nordby er professor ved Institutt for sosialvitenskap og veiledning ved Høgskolen i Innlandet. Han har doktorgrad i språk- og bevissthetsfilosofi fra University of Oxford. Nordbys forskningsinteresser er kommunikasjon, etikk og ledelse innen helse- og sosialfag. Han har en 20 prosent stilling ved Institutt for helse og samfunn ved Universitetet $i$ Oslo. E-post: halvor.nordby@inn.no 
Liv Randi Roland er høgskolelektor ved Institutt for sosialvitenskap og veiledning ved Høgskolen i Innlandet. Hun er tilknyttet master i tverrfaglig arbeid med barn og unge og videreutdanning i tverrfaglig psykososialt arbeid med barn og unge. Hun er for tiden koordinator for mentorordningen Nattergalen ved høgskolen. E-post: liv.randi.roland@inn.no

Mari Rysst er professor i samfunnsfag og sosialantropologi ved Høgskolen i Innlandet. Hun leder doktorgradsprogrammet «Barn og unges deltakelse og kompetanseutvikling» (BUK) og underviser på master- og ph.d.-nivå. Hun har også en bistilling ved SIFO ved OsloMet. Hennes faglige interesser er barn, unge, forbruk, kjønn, etnisitet, rase og sosial inkludering og ekskludering. E-post: mari.rysst@inn.no

Anders Sandvig jr. har i mange år vært ansatt som førstelelektor ved barnevernutdanningen i Lillehammer ved Høgskolen i Innlandet. Han har master i sosialt arbeid og er nå pensjonist. Ved siden av stillingen som førstelelektor har Sandvig jr. lang erfaring som fagkyndig i fylkesnemnda for barnevernssaker og som familiekoordinator i familierådsarbeid i Oppland. E-post: anders.sandvig@inn.no

Lene Nygaard Solli er stipendiat ved doktorgradsprogrammet «Barn og unges deltakelse og kompetanseutvikling» (BUK) ved Høgskolen i Innlandet. Hun har en tverrfaglig bakgrunn med bachelor i kultur og kommunikasjon (UiO) og master i sosialt arbeid med barn og unge (HNN). Sollis doktorgradsprosjekt handler om bruk av familieråd i barnevernet. E-post: lene.solli@inn.no

Kerstin Söderström er psykologspesialist med doktorgrad i psykologi fra NTNU. Hun arbeider i 50 prosent stilling som førsteamanuensis ved Høgskolen i Innlandet og 50 prosent i Divisjon Psykisk helsevern ved Sykehuset Innlandet HF. Klinikk- og forskningsinteresser er foreldre, sped- og småbarn med psykososiale belastninger, barn som pårørende, rusavhengighet og tverrfaglig samarbeid. E-post: kerstin.soderstrom@inn.no 